Illinois State University

ISU ReD: Research and eData

Theses and Dissertations

3-2-2017

\title{
On My Grind: Freestyle Rap Practices in Experimental Creative Writing and Composition Pedagogy
}

\author{
Evan Nave \\ Illinois State University, ebnave11@gmail.com
}

Follow this and additional works at: https://ir.library.illinoisstate.edu/etd

Part of the African American Studies Commons, Creative Writing Commons, Curriculum and Instruction Commons, and the Educational Methods Commons

\section{Recommended Citation}

Nave, Evan, "On My Grind: Freestyle Rap Practices in Experimental Creative Writing and Composition Pedagogy" (2017). Theses and Dissertations. 697.

https://ir.library.illinoisstate.edu/etd/697

This Dissertation is brought to you for free and open access by ISU ReD: Research and eData. It has been accepted for inclusion in Theses and Dissertations by an authorized administrator of ISU ReD: Research and eData. For more information, please contact ISUReD@ilstu.edu. 


\title{
ON MY GRIND: FREESTYLE RAP PRACTICES IN EXPERIMENTAL CREATIVE WRITING AND COMPOSITION PEDAGOGY
}

\author{
Evan Nave
}

\section{Pages}

My work is always necessarily two-headed. Double-voiced. Call-and-response at once. Paranoid self-talk as dichotomous monologue to move the crowd. Part of this has to do with the deep cuts and scratches in my mind. Recorded and remixed across DNA double helixes. Structurally split. Generationally divided. A style and family history built on breaking down.

Evidence of how ill I am.

And then there's the matter of skin. The material concerns of cultural cross-fertilization. Itching to plant seeds where the grass is always greener. Color collaborations and appropriations. Writing white/out with black art ink. Distinctions dangerously hidden behind backbeats or shamelessly displayed front and center for familiar-feeling consumption. Sell-out concerns always whispering or shouting further dissonance.

Hip-hop became home when it welcomed all the voices in my head. And anyone who knows me knows how hard it can be for me to leave the house. White-flight phobias in reverse. Pale-faced. Afraid I'll look like I've seen a ghost.

Hip-hop pushed me to split.

Like MF DOOM as hip-hop "Supervillain,” part hero, part madman, I come at writing and teaching writing ruptured. With desires to both build and destroy. Empower and selfdestruct. Anything inching towards complete cohesion a saving grace and the mark of the beast. 
Best to keep it real/reel. Fragmentation always feeling painfully honest.

So On My Grind is broken down into chapters of fragments designed to blur. "Hip-Hop Alone" written as both MC and alienated imposter. "Ain't Shit: Freewriting to Freestyling" written as both instructor-theorist and disillusioned hip-hop disciple. "Bootleg Ghetto Pass Revoked" functioning as both self-conscious Blaxploitation flick and freestyle praxis. Each of the chapters doing creative and critical work, as much a nod to my deep-seated belief in the power of edutainment as a conscious recognition that any hip-hop text is always doing at least a few things at once.

I'm most interested in the mess that happens when the chapters and fragments collide. The collage-effects made possible by the friction of the faulty/fault line design. Where the teacher-narrator of "Ain't Shit" buys psychiatric dope on the corner in "Bootleg Ghetto Pass Revoked," to numb the pain of the sick critic in "Hip-Hop Alone." The voices in the chapters, while not necessarily unified, certainly speak the same language. They talk shit to each other. Signify to spit the truth through lies.

All of it freestyled to the offbeat rhythms in my head. A suspicious half-trust in "first thought best thought" practices to the beat. Where editing meant freestyling over the original freestyles until they sounded right. Until they flowed. I flowed until I reached a flow state untouched by my illness. My mental state spit mysterious and spiritual. Ritualistic grinding through "ain't shit" states of mind with flow-faith.

On My Grind preaches belief and doubt. Devotion and heresy. Holding onto hope and completely losing it.

KEYWORDS: Hip-hop studies, Freestyle rap, Freewriting 


\title{
ON MY GRIND: FREESTYLE RAP PRACTICES IN EXPERIMENTAL CREATIVE WRITING AND COMPOSITION PEDAGOGY
}

\author{
EVAN NAVE
}

A Dissertation Submitted in Partial

Fulfillment of the Requirements

for the Degree of

DOCTOR OF PHILOSOPHY

Department of English

\section{ILLINOIS STATE UNIVERSITY}


(C) 2017 Evan Nave 


\title{
ON MY GRIND: FREESTYLE RAP PRACTICES IN EXPERIMENTAL CREATIVE WRITING AND COMPOSITION PEDAGOGY
}

\author{
EVAN NAVE
}

COMMITTEE MEMBERS:

Ricardo Cortez Cruz, Chair

Julie Cheville

Bob Broad 


\section{ACKNOWLEDGMENTS}

I'll probably never have a "shout outs" section in the liner notes of the inside cover of a rap album, so this will have to do.

First things first: I couldn't have pushed through, gotten over, or kept my head together without the endless support and encouragement of Professor Ricardo Cortez Cruz. If I'm the rapper, he's the DJ. Always bringing the noise and coaxing the right amount of wreck out of me. Trust: You'd never hear from me without him.

I'd also like to express my gratitude to Dr. Julie Cheville for teaching me what it means to teach writing thoughtfully, mindfully. With my head and heart in the right places. Her patience, kindness, and generosity allowed me to write this dissertation in my own time, in my own voice. She helped me sit with this project even when I didn't know what I stood for and, as a result, now I know where I stand.

Although we've only started working together somewhat recently, Dr. Bob Broad's expertise in expressivism and writing assessment challenged me to put my pedagogical money where my mouth is with this project. Put up or shut up, with an emphasis on value. What all this writing and teaching means when the chips are down. I want to thank him for buying into my vision for this dissertation and seeing it through to the end.

There were many members of the Illinois State University community who supported me, held me down, while I worked through the PhD program. I specifically want to thank Dr. Steve Halle and Tara Reeser for helping me stay focused on what mattered most— bettering myself and doing work I believe in. I'm a better/badder writer, teacher, and person for knowing them.

Finally, I want to thank my best friends, Robert Harrison and Charish Halliburton, and my partner, Alyssa Bralower, for being there for me, having my back, as I wrote this dissertation. 
They were always all ears when I needed to rap about my writing, and their unwavering belief in me and my work consistently reminded me why I do all this. Much love.

E.N. 


\section{CONTENTS}

Page

ACKNOWLEDGMENTS

i

CONTENTS

iii

CHAPTER I: HIP-HOP ALONE

CHAPTER II: BOOTLEG GHETTO PASS REVOKED

CHAPTER III: AIN'T SHIT: FREEWRITING TO FREESTYLING

REFERENCES

306 


\section{CHAPTER I: HIP-HOP ALONE}

\section{Hip-Hop Written - Pt. 2}

dream hampton doesn't remember the specific moment she became a hip-hop writer. She never consciously planned on blending her passions for writing and hip-hop, she says_- "It just sort of happened" (Rausch 85). I remember the day I became a hip-hop writer because I still have the calendar on a bookshelf, stuck between Mumia Abu-Jamal's Live from Death Row and a Merriam-Webster's Rhyming Dictionary. I became a hip-hop writer on the calendar. Literally. I transcribed Sister Souljah's The Coldest Winter Ever word-for-word in the date boxes from December 22 to March 20. To get through the cold itself where I lived. Something cold that happens in my mind when it snows. When I turn cold-blooded on myself and start hearing JayZ's “D'Evils” like a palm reading. Frostbit. I had to take a pen into my palm like divinely inspired scriptures. I had to write 8 hours a day, obsessively, to be prolific like Tupac Shakur in the studio. Chapter after chapter like tracks. Put in work. Pay my dues. Do penance. And I had to write so small to make the sentences fit that the words were unreadable. My hands shook and ached from the tedium built into my practice. But I was drawn to the precision and routine. My mind filled with escape routes. My mind filled with rap-styled first family Mafiosos and the women who love to love them. I thought about buying a gun and ending every day's work with a bullet. I thought about buying a gun and using it as a paperweight, so the work wouldn't blow me away. I was drawn to the punctual violence. I could put my finger on it. The characters spoke in subliminal messages. All of them confirmed my authenticity. They included personal anecdotes in paratext. I used a pill bottle full of anti-depressants as a paperweight instead. Its dosage instructions included personal anecdotes as paratext. I wrote until the work was finished and I 
was a hip-hop writer for real. I closed the windows until I was finished and winter was over and woke up on the first day of spring a hip-hop writer with a body of work to prove it. 


\section{But Both}

To me, hip-hop is the tension between trash and talent. What's overlooked and left behind and what's worth holding onto. A "started-from-the-bottom-now-we-here" ethos where "the bottom" and "here" could be indistinguishable outside the hip-hopper's head. The shifting signifiers situated loosely between performance and belief. Hip-hop requiring a certain religious faith in the unknown. Speaking/writing/dancing/spinning something bigger than oneself into existence to imagine something bigger than oneself is possible, period.

And the ritualistic payoff is recognized in the transfiguration of trash into medium in the mind of the believer. Where abandoned wall becomes graffiti canvas, worn-out turntable becomes avant-garde instrument, dirty asphalt becomes dance floor, foulmouthed vocalization becomes local poet laureate opportunity. Even while they all remain, have to remain to stay real: abandoned, worn-out, dirty, and foulmouthed.

Hip-hop happens in the tension between the unclean and the so fresh and so clean.

With the shit and style rubbing off on practitioners' perspectives of Knowledge of Self. Who they/we are as hip-hop acolytes: both nobodies and somebodies depending on the moment and audience, both unheard and heard depending on the volume levels and who's listening, both worthless and worthwhile depending on one's abilities to imagine the repurposed as purposeful.

Hip-hoppers don't suspend their disbelief when it comes to the existence of trash.

Instead, they believe and then some. Trash becomes the starting point, the raw materials for products/projects that are both waste and worthy. Embodied cultural artifacts that are aware of their abject origins. Hyperaware, in fact, to the point of obsessive-compulsive self-referential pride. 
Hip-hop requires its adherents flaunt their castoff abilities with a style that inspires reclamation, even if the salvaging process only goes down in their own revolting minds. 


\section{Hip-Hop Written - Pt. 1}

True to the game, Adam Sexton pulls no punches when it comes to his assessment of hiphop writing. In the "Introduction" to his edited collection Rap on Rap, he breaks it down like this, "Straight up: most hip-hop criticism is either ill-informed rap-bashing of the it's-not-evenmusic! variety (sic) ... or, at the other end of the spectrum, your basic cheerleading” (3). In addition to recognizing the troubling "for us or against us" binary that exists in so much hip-hop journalism and scholarship, he takes writers (especially white ones) on both sides of the ideological divide to task for failing to adequately address issues of race and racism in their work on hip-hop culture, aesthetics, and artifacts (5).

Sexton argues that hip-hop critics too often miss the political size, scope, and urgency of their subject matter, preferring instead to play it safe and stay on the surface of what they consider to be little more than mainstream American popular culture. But he notes the incompatibility of transgressive art and lifeless writing; hip-hop writing has to be crafted out of the same radical, almost desperate (do or die), energy expressed through other hip-hop mediums (e.g., MCing, DJing, B-girling/boying, graffiti), or else risk missing the whole creative point of the culture. Writers who write on hip-hop should approach their art like any other hip-hopper would, and they better come correct. Because, as Sexton concludes, hip-hop "deserves ... a criticism as innovative, and yet as rigorous, as the best rap music itself” (13).

And to all of this I say: Write on.

Because I want hip-hop writing (criticism and beyond) that excites, inspires, and provokes. I want hip-hop writing that refuses to let me sit still. I want hip-hop writing that is the movement of the breakdancer, the sound and touch of the turntables, the smell of aerosol paint on the wall. I want hip-hop writing that is the voices of the bodies at the party. I want hip-hop 
writing that is the reason someone calls the cops. I want hip-hop writing that makes something out of nothing and survives on style and skill or doesn't survive at all. I want hip-hop writing that makes me want to fight (something, someone, even if it's myself). I want hip-hop writing that engages the aesthetics, techniques, and goals of other hip-hop arts. I want hip-hop writing that becomes an indispensible element of hip-hop culture (like, folks wouldn't know how to hip-hop without it). Most of all, I want hip-hop writing that deserves to be called hip-hop writing because it has proven itself useful and necessary to people who need hip-hop on the page to keep reading. And so far, I'm not seein' it.

I haven't found much of this writing in the glossy commercial rap magazines that appeal to the lowest common denominators of the mainstream rap industry (hyperconsumerism, hypermasculinity, hypersexuality). And I haven't found much of this writing in the scholarly publications that have brought hip-hop into the academy (What academics possess in terms of critical insight and analytical abilities, they often lack in terms of originality and style). But I know innovative hip-hop writing exists because it has in the past (in throwback editions of indie publications like the Village Voice, in anthologies of inventive hip-hop journalism, in more experimental hip-hop literature) and it has to continue to exist in the future if hip-hop culture is to remain relevant and literate (i.e., a culture worthy of being written and read about.) And to this hip-hop future I say: Write on. 


\section{Happenin' Writing Happening}

This writing is what happens when you take OutKast's "Da Art of Storytellin" series as seriously as Janet Burroway's Writing Fiction: A Guide to Narrative Craft. Even more seriously. It's what happens when you replace William Zinsser's On Writing Well with Escher's The Rapper's Handbook: A Guide to Freestyling and Writing Rhymes, or read them both at the same time, one in each hand.

This writing is what happens when you self-educate on turntablism as a way of reading the university library collection's marginalia. When you read the university library as a threat. When you "read" the university library like Paris is Burning. When you write your own vicious marginalia like graffiti burners with Zebra Katz's “Ima Read" playing on your headphones. This is that writing that happens when you're in the university library reading and think to burn the motherfucker down. When you're down. When you're writing to be down. When you're lowdown. When you're listening to Talib Kweli's "So Low" and highlighting whole sections of David H. Richter's Falling Into Theory: Conflicting Views on Reading Literature at the same time.

This writing is what happens when you're assigned to read Chinua Achebe's Things Fall Apart, and you listen to The Roots's Things Fall Apart instead. When you try to talk your way out of the mix-up. When you practice your bourgeois bilingualism and speak polyglot and pidgin-funkified trying to prove yourself to an empty lecture hall. This writing is what happens when an academic gets gritty-smart but cordial like Michael Eric Dyson and something has to be done about it, or when the academy accidentally opens its ivory doors to an undercover hip-hop head and no one notices until it's too late. When it's too late. When it's been too late. 
This writing is what happens when Marc Lamont Hill already exists and isn't returning any of your phone calls. When you're worried he's talking with Michael Eric Dyson about you behind your back. This writing is what happens when educated people ask what you consider to be the most influential work of $20^{\text {th }}$ century literature, and you say Tupac Shakur's All Eyez on $M e$, and the whole class stares like, "Who asked you?" When you can't remember who asked you. When you weren't listening in the first place. When you can't hear anything over the white noise in your head. When you can't find a copy of Tricia Rose's Black Noise: Rap Music and Black Culture in Contemporary America on audiobook, so you resort to reading Michel Foucault's Madness and Civilization: A History of Insanity in the Age of Reason with MF Doom's Operation: Doomsday playing in the background for affect. When you're doomed. When you know you're doomed. When you write what you know. When you don't know shit. When you listen to Erykah Badu teach, "The man that knows something / Knows that he knows nothing at all," and assume she isn't talking about you. When you practice hip-hop writer Charles Aaron's “double-unconsciousness” instead of W.E.B. Du Bois's “double-consciousness” by accident and then later, when you know better, on purpose. When you don't know what you don't know. When you know nothing enough to write.

This is what happens when you write nothing to a J Dilla beat and call it ghostwritten scholarship on rhythm as "both a skill and an existential experience of being," like you're scholar Birgitte Stougaard Pedersen or something (59). When you consider Kierkegaard to the rhythm of the weather in Missy Elliot's “The Rain (Supa Dupa Fly)." When you consider the rhythm of the throbbing in Tupac Shakur's “Bring the Pain.” When you wish you would've listened to Tupac Shakur's "No More Pain" instead. When you listen to Method Man's "Bring the Pain" and wish you hadn't at all. When you should have read Elaine Scarry's The Body in Pain: The Making and 
Unmaking of the World instead. This writing is that happens when you try to read Virginia Woolf's “On Being Ill” but listen to the Beastie Boys' Licensed to Ill instead. When you're ill. The writing being something that happens when you're the illest. 


\section{Fragment \#1}

I didn't leave the house from the ages 13 to 22 for psychopolitical reasons. I refused visitors and interlibrary loan requests. In some ways, it took on a cultural hunger strike feel. I completed high school and college requirements through an elaborate correspondence course program designed for aspiring revolutionaries. My teachers were Miles Davis, 50 Cent, and a faceless Black Feminist known nationally for her radical practices of the First Amendment. I failed almost all the curriculum because I was distracted by endless streams of Black Entertainment Television. Watching it in marathons became an anthropological experiment like something out of The Boondocks cartoon.

No mirrors were allowed in the home for psychopolitical reasons. Daily blood tests measured neurotoxicity levels. I immersed myself in a Sony Walkman Personal CD Player I had mail ordered from a thick Sears catalog. I listened exclusively to "conscious" rappers critique the 2000 and 2004 U.S. presidential elections. I began collecting Black bodies in my imagination; I had not read Adam Hochschild's King Leopold's Ghost or Joseph Conrad's Heart of Darkness. I had not memorized a map of the African continent. John Lewis was not dinner table conversation. I threw up almost constantly from a warm disconnect between my mind and white body.

I assumed everyone else was fluent in Ebonics. The booklets in the CD packaging served as both dictionary and thesaurus. I wrote a colorblind racial manifesto of my own in the booklets' margins and felt no shame. I criticized the lack of Black representation in John Hughes's The Breakfast Club but assumed it correlated with the demographics of at least some Midwestern high schools. No one broke down my bedroom door to disagree. 
My parents were both white Americans of the light blue-collar political persuasion. They ran an economy of moral majorities. I tried to read Gandhi's The Story of My Experiments with Truth, but ended up watching Gandhi starring Ben Kingsley instead. It lit a moral path. I tried to read The Autobiography of Malcolm X, but watched the Spike Lee joint Malcolm X starring Denzel Washington instead. I became obsessed with hair processing chemicals and pump-action rifles. Race was the new black.

When I finally stepped outside, it was winter and Queens MC Nas had declared hip-hop long dead on his 2006 album Hip-Hop is Dead. I saw three hundred and sixty degrees of white people. I was white on both sides. I had the funk of being homebound. I condensed my homemade liner notes into lyrics for an independently produced album I titled Homebound Funk. It was poorly received commercially and critically, so I submitted it as a creative sample to an English graduate program. I was wantonly rejected and took up a hip-hop self-education program outlined in M.K. Asante Jr.'s It's Bigger than Hip Hop: The Rise of the Post Hip-Hop Generation and William "UPSKI” Wimsatt's essay "How I Got My DIY Degree at the University of Planet Earth." My senior thesis was an experiment in "freestyle rap writing" called Bootleg Ghetto Pass Revoked that was wantonly rejected as "a serious threat to the game." 


\section{Battling}

Hip-hop has always been about confrontation. Whether this confrontation is between freestyle rappers rhyming for cipher supremacy, DJs trying to outblast each other's sound systems, or an entire youth subculture actively rejecting a mainstream status quo political and social establishment or institution, hip-hop has always meant putting something on the line against someone or some group who is in it for high stakes. In his interview with Zulu King bboy Alien Ness, hip-hop scholar Joe Schloss notes that for practitioners of the Elements, "the battle is everything: a method of conflict resolution, a work of art, a teaching tool, even a personal catharsis" (27) He continues, "Ultimately, battling teaches its disciples how to use style to reconcile opposing forces, a skill that may well be at the heart of hip-hop itself” (Schloss 27).

So the hip-hop battle, regardless of its elemental expression, tests who can maintain their composed cool, their personal aesthetics, their undeniable and unmistakable style, while remaining within the tension of opposition. The winner is the head who performs at a high level despite pressures to represent herself and her crew to the utmost. The champion is the one who not only survives the battle, but also thrives when presented with the opportunity to test the mastery of their skills against another practitioner. All battlers knowing, of course, that whether or not they come out the victor, there will always be more battles to fight, more chances to prove oneself, more comrades to meet and enemies to vanquish. The battle for supreme style being more than a battle, but a lifetime of war to prove you, your crew, and your neighborhood, are the real deal Holyfield.

But when you hip-hop alone, the battles become more abstract. You wonder how to best represent yourself and your style when there is no opponent in front of you to distinguish yourself from. You wonder how to best hold it down for your crew and your neighborhood when 
the members of your crew are voices from textbooks and faces from a TV screen, and your neighbors haven't come out of their apartments since you moved in. Your neighborhood a construction of cubes in a square without a name or reputation.

You try to shadowbox with the illest MC you've ever heard or the cat with the sickest sound system in the borough, but you realize, after enough sparring sessions, that the voices and sounds are imaginations of who could shape or hurt you if there was anyone else around to watch and witness.

And the natural outcome is that you turn the battle inward and start to style and profile against yourself. Like the highest royalty reigning over the balls thrown in Paris is Burning, you start to "read" yourself like a trashy paperback novel. You signify all over your sorry self until there's nothing left to prove. Everyone watching knows who's the truest in the game.

But you're the only one watching, and the battlers are you against you, and the winner and loser are you in the same. That healthy tension that exists naturally in opposition and that is released when the smoke clears starts to wear on any style you thought you had to begin with. Because the competing styles, both your own, or imaginations of superior styles you can't compete with in the first place, are always one critical step ahead of each other. They know each other's best moves before they're ever performed because they were born and raised on the same anonymous block. And sooner or later the battles become unbearable, insufferable, useless. You flailing hopelessly at the baddest b-boy there never was. 


\section{Problem \#1}

The problem with Evan Nave is how desperately he wants to be Tupac Shakur. Down to the "Thug Life" tatted across his belly and AK-47 and "50 Niggaz" tatted above that. Down to the dying-for-his-people narrative glorified by no one. Because he doesn't have a relevant death, or a people to speak of or to. Watch him sometime if he ever leaves the house. No one's on the block hollering. Because Nave puts nothing on the line but still stubbornly refuses to untie the bandana from around his forehead. It's a costume for a performance audiences don't care to see; nobody's interested in literary thug minstrelsy to bad music and worse choreography. I'll save Stanley Crouch and company the copy space: Bootleg Ghetto Pass Revoked is a eulogy at an unattended funeral—all talk, and the coffin's empty, too. It's a bait and switch rip-off that lacks the common decency to promise you something good in the first place. Nave's work is Shakur's concrete with no growing red rose. 


\section{Artademics}

I want hip-hop scholarship that reads more like hip-hop literature, where researchers present their work more like artists than academics. Where hip-hop researchers call themselves "artademics" and stand proud off their shine.

Scholarship where the research's hip-hop-related content is expressed by its author consciously utilizing hip-hop aesthetics, perhaps most importantly the technique novelist Adam Mansbach refers to as, "intellectual democracy through collage: the idea that whatever's hot is worthy of adoption regardless of its location or context" (93).

Where hip-hop scholarship takes on hip-hop's form.

A form that values anything and everything as potential citable material within the research project. And where doing the research is like digging through milk crates full of old records looking for just the right sound to sample. Where DJs are seen as researchers in their own right. Where scholarly research materials are intellectual and rhythmic (language-sound) samples to collage. Where citing begins to feel like DJing.

I want hip-hop scholarship written by researchers who consider themselves intellectual DJs. Where researchers consult outdated texts like John Lynch's How to Make Collages to get a feel for blending outside ideas with their own.

I want hip-hop scholarship with layers of meaning like a rap song, where you can understand only as much as you bring to the material from your own Knowledge base. Where the more you know and learn, the more you know and learn.

And the beat goes on.

I want hip-hop scholarship that encourages readers to speak/write back to what they read, scholarship that is as based in call-and-response rituals as hip-hop music itself. Scholarship that 
says something to be heard and responded to. Scholarship that puts something personal on the line. I want hip-hop scholarship that demands its readers put something on the line, too. High stakes cultural studies, for real.

And I want all this because, as it has existed up to this point, most hip-hop scholarship is almost completely inaccessible to most members of the hip-hop community (i.e., those who love hip-hop but do not find themselves in the American academy). Consequently, most of the best thinking and writing on hip-hop is not read by the masses that make up the Hip-Hop Nation. This is unacceptable. Not only because high-quality hip-hop scholarship deserves a wider reading audience, but because hip-hoppers of all backgrounds deserve writing they can read and nod their heads to.

Real talk: Most hip-hoppers do not read dense theoretical texts like Tricia Rose's seminal but difficult Black Noise: Rap Music and Black Culture in Contemporary America. Most hip-hop fans would rather listen to mainstream rap radio than analyze essays from Murray Forman and Mark Anthony Neal's That's the Joint!: The Hip-Hop Studies Reader. Even more approachable texts like Jeff Chang's comprehensive Can't Stop Won't Stop: A History of the Hip-Hop Generation can become tedious with its wealth of culturally specific historical references. Most hip-hop scholarship is hard work to read.

Realer talk: Even if most hip-hop heads had access to scholarly article databases, university library collections, and postgraduate educations, they probably still wouldn't want to read most hip-hop scholarship because it is too often dry, impersonal, teachy, and boring. In other words, much hip-hop scholarship is the stylistic opposite of all the other Elements of hiphop culture (MCing, DJing, breaking, writing graffiti). This won't fly. 
Hip-hop scholarship must reach hip-hoppers on the same interpersonal, visceral, competitive, political, do-or-die levels as the other Elements; if it doesn't, it ain't hip-hop. Straight up. Even worse, though, if serious hip-hop writing takes on the exclusionary, elitist, overly academic tones it often has and does, it's in danger of promoting the normative values and dominant institutions hip-hop was created to confront. Hip-hop writing's values could become antithetical to hip-hop culture's ideals.

Hip-hop writers can do better, badder work.

And I get it, not everyone can be Greg Tate or Joan Morgan or MK Asante or William "UPSKI" Wimsatt. But hip-hop scholars can learn a lot from these artademics when it comes to making our work accessible to a broader rap readership. We can learn to ditch the academic jargon in our writing and go for the throat of the issues we're addressing (like any good freestyle rapper). We can learn to insert ourselves, our own personality, investments, and vulnerabilities into the hip-hop writing we produce (like any MC worth her salt). And perhaps most importantly, we can learn to write like nothing else matters, like it's our turn to put up or shut up, like we better say what we have to say because silence means a missed opportunity to move the crowd.

And the crowd is waiting. 


\section{Lonely}

There hasn't been enough written on the intersections between hip-hop studies and mental illness; no groundbreaking text like Mad at School: Rhetorics of Mental Disability and Academic Life exists for the aspiring hip-hop artist/scholar. And in absence of such a text, I've taken to self-medicating from within hip-hop culture itself, popping prescription samples from a medicine cabinet full of artifacts stocked by ghetto philosopher drug reps. I've taken to speculating on what happens when, as Lauryn Hill prophecies (and Kanye West samples), it "All Falls Down." I've worried West was right on when he produced “This Can't Be Life.” I've worried he was autotuning me out on "Heartless." I try to tune more directly into his rewrite of "Stronger."

And as hard as I try, all I seem to hear is Tupac Shakur open "Changes" with, "I wake up in the morning and I ask myself / Is life worth living should I blast myself?” Or Notorious B.I.G. on "Everyday Struggle" when he laments, "I don't wanna live no mo' / Sometimes I hear death knockin’ at my front do'.” Or Inspectah Deck when he reflects on Wu-Tang Clan’s “C.R.E.A.M.," “Though I don't know why I chose to smoke sess / I guess that's the time when I'm not depressed / But I'm still depressed and I ask what's it worth?” Or Killer Mike on “All Due Respect," when he raises his hand and says, "We the goddamn reason for Ritalin / In the back of the class twitchin' and fidgetin'." Or the worst, when Lil' Wayne murmurs "I am a prisoner, locked up behind Xanax bars" before hopelessly spiraling into the hook, "Only once the drugs are done / Then I feel like dying, I feel like dying.”

And even if "It's like that / And that's the way it is" for these distraught rappers, their lyrics make it almost impossible for me to get "My Mind Right"; they're way too (Memphis) Bleek/bleak. Furthermore, and more importantly, they can't be the only mental health messages 
from the contemporary hip-hop canon that stick in heads' collective consciousness. They can't be the dominant discourse on the mad ill. Because if they are, hip-hop is stuck with a soundtrack for self-destruction more dangerous than anything the FCC can smack a "WARNING" label on. Yasiin Bey (fka Mos Def) describes hip-hop as "medicine for loneliness," so I take it daily with a glass of water, on a full stomach. Religiously. Even though Erykah Badu sings, “Hip-hop / It's bigger than religion.” Even though I'm not positive about the Trinitarian theology behind, "Jesus Walks," and despite the fact that I can't buy into Kendrick Lamar's doctrine on "Kush \& Corinthians." All smoke and mirrors. Hot air from the pulpit. I partake of the holy body(rock) and drink the water that's wine that's blood like a red bandana despite my best efforts at denial and blind faith. Knowing damn well Mos ends "Hip-Hop" with the secular reminder that "it can't save you." 


\section{Fragment \#3}

Greg Tate once told me, "Hip-hop is black Prozac" (20). I told him, "Prozac is white Prozac." And we spent the rest of the evening arguing over what would happen if someone took doses of both drugs at the same time and flipped out. Like would they slip into a gray in-between space of completely calm youth rebellion? Would their brain waves slow to the BPM's of a

hybridized race music? And maybe most importantly, how long would the high last, and would there be serious side effects or threats to the addict's overall physical and psychological wellbeing?

I decided to play mad scientist and run the experiment on myself while Tate identified as the control group. He watched through a two-way mirror while I dry-swallowed carefully dosed capsules and listened intensely to Kendrick Lamar's Compton-hallucination good kid, m.A.A.d. city on repeat. I kept a personal journal during the trials as documentation of my varied mental states in the doped-up moments, and after our research was completed Tate submitted the manuscript to a handful of scholarly journals in the fields of adolescent psychiatry and musicology under the tentative title Bootleg Ghetto Pass Revoked. 


\section{Can't Stop, Won't Stop}

Open to any page of Jeff Chang's groundbreaking Can't Stop Won't Stop: A History of the Hip-Hop Generation, and you'll find hip-hoppers doing hip-hop together. The emphasis on together. Every page is the Hip-Hop Generation generating hip-hop culture together. Engaging the sacred Elements together-for and with each other. Partying till the break of dawn (and then some) together. Making a collective something out of their individual nothings together.

Becoming somebodies instead of nobodies by surrounding themselves with other nobodies trying to be somebodies - together. Get it?

Hip-hop ain't hip-hop alone.

Only I misunderstood Chang's title and historical subject matter and read Can't Stop as an obsessive-compulsive disorder self-help book. A remix gone wrong. Like it was an irrational invitation to be part of the realness. Together. With the original heads, hip-hopping compulsively. Goin', goin', outta control. I set it off.

I read Can't Stop cover-to-cover and listened to Queen Latifah's “Wrath of My Madness" on repeat. I read it again to keep hip-hopping. I'm in the middle of rereading it now and writing my own hip-hop to be a part of it. To the point that I literally can't stop. Brainsick. The illest.

Hip-hop being the oven knob I'm never completely sure I turned the volume down on before going to bed (The symptom behind why I bought the self-help book to begin with). The fear of letting it leak before its release date. It's gonna blow up. It's gonna be hot. We don't need no water, let the motherfucker burn!

No. Hip-hop having become the getting up in the night fear, and checking again for sure, and walking away again half-satisfied. What's cooler than bein' cool? Ice cold! Shiver-fright. Super chill. 
No. Even more, hip-hop being the getting up and checking again and again can't stop fear. Mind scratched and looped. And it don't quit.

These are the breaks.

These are dissociative breaks alone while Nas and Puffy are all, "You can hate me now / But I won't stop now / Cuz' I can't stop now.” And the hatred is there and real, alone trying to stop. It won't stop. Bet.

And hip-hop ain't hip-hop alone. I double-checked the information contained in Can't Stop Won't Stop's "Endnotes." I triple-checked the "Index" for instances of the word "alone" and didn't find anything. I keep getting up in the night and searching through the pages of Can't Stop Won't Stop: A History of the Hip-Hop Generation for references to loneliness or instances of my name together with everyone else hip-hopping. I keep writing my first name over and over in the margins of the "Index," small between the entries for Medgar Evers and James Baldwin's The Evidence of Things Not Seen. 


\section{What's My Name?}

When Snoop Doggy Dogg repeatedly asks, “What's my motherfuckin' name?” on "Who Am I? (What's My Name?)" we're never led to believe that the rapper has actually forgotten his identity. He's incredibly sure of himself, he just wants to make sure everyone else in the place knows who he is, too.

The same can be assumed of DMX on his track "What's My Name?" where the rapper says his own name at the beginning of the hook but wants the crowd to know it by heart and say it too, and loud. In their own ways, Snoop and DMX are engaging in call-and-response selfaffirmation rituals with listeners, with the rappers calling out, "This is who I am!" and the crowd responding, "This is who you are!" The rappers calling out "Do you know who I am?" and the crowd responding, "We know who you are! (and maybe who we are, ourselves, in relation to you)." Within these rituals, which have existed since the birth of hip-hop party culture, MCs and audience members participate in self-identification, and re-inscription of these identities, through repetition.

Hip-hop demanding folks recognize and respect the power of the name.

But when you hip-hop alone, it is more difficult to remember who you are. You might have an idea of your own name, but when you ask the no one around whether they know and recognize it, you have to take the silence at face value. If you're feeling more desperate, you might, like DMX, call out "What's my name?" but without a crowd to respond, "This is who you are!" your identity might start slipping like a microphone through your fingers. You might start talking to yourself in different tones, trying to play both sides of the call-and-response. But you'll never be able to disguise your voice well enough to convince yourself, to trick yourself into company. 
You might start assigning yourself names at random, hoping one of them will sound right and stick. But more than likely, you will reach a point when you're reduced to hip-hopping without a for-sure name altogether, and you'll look back, later, on the artifacts you made and wonder why anyone would waste their time on something they couldn't claim for themselves. 


\section{Fragment \#2}

In 2003, I was cast to play a whiteboy named Jeffery Jacobson for a sketch on Chappelle's Show. The bit was called "Trading Spouses," a play on the TLC show Trading Spaces that was popular with middle-class white people at the time. The premise of the sketch went like this: a white man and white Black man trade families for a month to see what kind of wild and hilarious miscegenation can go down while the cameras are rolling.

My character was the white son who gets taken up by a new, no-nonsense Black father named Leonard Washington (a Samuel L. Jackson-looking motherfucker with an attitude to match.) When I'm in and out of character I'm a bratty suburban kid in starched denim and a doorag listening to gangsta rap so loud it disrupts Leonard Washington's watching Martin on TV. So he barges in and asks about the racket, and I say my one big setup line, "It's the new 50 Cent. I'm from the streets, man. G-G-G-G-G-G-G-Unit!" Then he comes back with, "G-G-G-G-G-GGet yo' ass in the car," to the live studio audience laughter and applause for more and more culture clash. And then when the camera cuts back, Leonard Washington's dropping me off on the block for a taste of my own cough medicine. Like, if I can talk it ,I better be able to walk it. "Here you are, moptop," he says. "Home sweet home - the 'hood. All right, lil' fella. Say hello to your people for me. And tell 'em when you see ‘em that Leonard Washington's glad he made it out. Go on. G-G-G-G-G-G-Goodbye!" And he drives away, leaving me face-to-face with the content of Get Rich or Die Tryin' with none of the survival skills or braggadocio.

The scene wraps.

Only it doesn't end there for me because the camera crew loads up their equipment in the van and hauls ass outta there, and I'm alone with the extras sitting on the stoop talking shit. And I start playing through all the ways my pre-pubescent white self can be interpreted like it's on 
location for a rap video. But the fourth wall is gone and I'm panicking in three dimensions, clean out of my skin and lost in a concrete jungle. And I take the temperature of the situation and realize it's too hot to handle. So I jump in front of the nearest stray taxi headed for the highway, like I gotta make it to heaven and fast, and watch the headlights meet mine and flicker to black. 


\section{Diss Tracks}

Sometimes rappers go at each other on the record. They trade words, threats, salacious lies. Quite far from Afrika Bambaataa's hip-hop community ideals of "Peace, Love, Unity, and Having Fun," rappers sometimes spit in each other's face, scuff each other's fresh new sneakers, talk about each other's mothers or girlfriends or kids; in short, sometimes rappers start beef (Chang 105). When the beefs are aired out on wax, for rivals and audiences to buy and share and hear, the recorded results are called "diss tracks."

In his article dedicated to the subject, Daniel Gilligan characterizes diss tracks as a situation where, "One lyricist is pitched against a rival to air their disagreements with one another. Creative rivalries are publicized, escalated, and at times resolved through a war of words, taunts and insults" (14). The author spends the rest of his piece analyzing famous historical diss tracks battles (Ice Cube vs. Common, Jay-Z vs. Nas, 50 Cent vs. Ja Rule) and theorizing the characteristics of and motivations behind each example.

The crux of Gilligan's conclusion draws on Michael Eric Dyson and Byron Hurt's work on hip-hop's embodiments of black masculinity, as well as Michael P. Jeffries's and Richard Majors's individual contributions to notions of black male authenticity and performativity, and it goes as follows: rappers create and release hypermasculine diss tracks (filled with graphic threats of violence, boasts of sexual prowess and strength, etc.) to publically question and put in doubt the masculinity and authenticity of an opposing MC (Gilligan's theory overlooking altogether the fact that female MCs can trade diss tracks with the best of 'em). A diss track is one rapper saying to another, "You're not as bad as you claim to be, and even if you are, I'm the baddest motherfucker there ever was." 
For Gilligan, rappers use diss tracks to promote fantasies of their own invulnerability (in the face of the white American hegemonic power structures and opposition from contending MCs) while at the same time disparaging the alleged real-life vulnerabilities of other artists they deem unfit to play the rap game (14). Beef is all about predator and prey, claims and counterclaims, all in an effort to decide who is fittest for survival on the Planet Rock.

But when you hip-hop alone, there is no one there to diss because there is no one there to begin with. You could lay down a diss track directed at someone you've never met, but it would more than likely come off as a pathetic attempt to pick a fight with a stranger and prove yourself to no one watching or listening. Or I suppose you could put out a diss track aimed at the whole world, to punish it for coming at you first, but then you'd be throwing haymakers at social constructs and focus groups and your work would read like an existential temper tantrum. And the whole point of a diss track is to prove you've got it all together.

So the last and most realistic option is to point the diss track at yourself and see what happens, something like Kendrick Lamar in the first part of "u" off To Pimp a Butterfly, when he screams very alone into a mirror and cries, "Loving you is complicated," and, more to the point, "You ain't shit / I'm convinced your talent ain't nothing special." Because you have to say something to someone to prove you exist (saying nothing was never really an option for any true $\mathrm{MC}$ ), and you can go at your vulnerabilities best because you know them intimately and have always known them.

You can use your diss track to oscillate between bravado and self-loathing and do your best to trick yourself and no audience into believing that the two don't come from the same place. That they weren't born of the same melodramatic need to feel something for yourself. You and no one else will be gullible enough to really buy into it. 
You can use your diss track to go beyond questioning the believability of your performance of gender to topics like: “Have you been a burden on everyone you know ain't gonna cop this shit?" and, "Would it be better for everyone involved if you just spun your advantages on a turntable and walked away?" and, "Has this been a blackface thing since the very beginning, or has it only recently taken on minstrel tones?"

You can list the diss track on your résumé under "Special Skills" and use it to convince a potential employer that you have experience in the entertainment industry. You can sell copies of the track out the trunk of your car at an exorbitant price and justify the figure by citing all the intense spiritual work you had to put in just to listen to your own voice. You can use the extras as stocking stuffers for the relatives who put up with you around the holidays. Or you can run over way too many copies with a bulldozer to make a weak political point about the importance of family values. For all I care, you can write a scholarly article theorizing the characteristics of and motivations behind your diss track and send the results to Gilligan for peer review. Just don't list my name in the bibliography. 


\section{Problem \#4}

Look at Evan Nave chewing on used copies of Geneva Smitherman's Black Talk and Clarence Major's From Juba to Jive: A Dictionary of African-American Slang. Trying to get the chain-restaurant taste out of his mouth. Trying to taste something new-with flavor. Where he doesn't even have to cook. Where he can order take-out and eat.

Hear him change his tone when he talks to someone with more influential melanin. When he has that looseness he learned from the bluebird in Walt Disney's Song of the South. Or when he karaokes fifteen-year-old rap shit and everyone else eats white birthday cake and shakes their head like, "Damn, I didn’t know he had it in him."

They mean a showboat black tongue, while the lyrics on the monitor are background color-neutral.

And he's at his worst in front of a captive audience, when they expect a certain diction and investment reflective of a middle-class upbringing. Don't even get me started on his manic preparation the night before he speaks, or ten minutes to showtime, hyperventilating in the bathroom, meant to ensure the performance of a certain culturally appropriated sound that proves he sampled all the right handbooks. Taste testing. Like, should he try to be more like linguists Walt Wolfram, or Rickford \& Rickford, or go all anthropological counterfeiter and pull an Alan Lomax?

Like he can walk it if he talks it first. 


\section{Self-Destruction}

Although one of the Universal Zulu Nation's sacred "Infinity Lessons" asserts, "The job of a Zulu is to survive in life," there is no specific mention of whether this dictum refers to survival in the face of external or internal threats or both (Chang 101). Living instead of dying can take many forms. Our minds, for example, live somehow with our bodies, but the jury's still out on whether or not there are any further (dis)connections. It's a Descartes kinda thing. Hiphop offers its own life-or-death philosophies.

For example, rappers like Tupac Shakur and 50 Cent have cut tracks that boast of surviving assassination attempts, their bodies getting shot with bullets but refusing to die until sometime later on (1996 and not yet, respectively). K'Valentine uses the Talib Kweli song "These Waters" to proclaim, "Surviving was my first adult decision"; like everything up to that identifiable maturation point could be credited to her elders' protection and good luck. The 1989 hip-hop hit "Self-Destruction" by the Stop the Violence Movement, although not advocating for preservation of the individual "self" necessarily but rather the black community at large, preaches a message of collective survival in the face of desecration by self-inflicted harm (i.e., black-on-black violence).

It seems like many hip-hop songs are saying, effectively, "Don’t let outside forces destroy you," be those forces semi-automatic weapons, mortal enemies, oppressive and unsafe living conditions, poverty, or hegemonic power structures and the ways they manifest themselves as human, physical violences. However, there are fewer overt messages in hip-hop that say, "In addition to not letting outside forces destroy you, don't destroy yourself, either." This disparity likely has its roots in Maslow's Hierarchy of Needs, where keeping one's embodied being safe from environmental dangers takes precedence over self-love and self-care (i.e., You can’t 
achieve compassionate self-actualization if you're mortally wounded from police brutality, gang warfare, food insecurity, unequal and inadequate healthcare, homelessness, etc.) And there are good reasons for hip-hop's placing primacy on the protection and strengthening of black and brown bodies; these bodies have been, and still are, targets within what has been called the HipHop Generation.

But there needs to be a continuing shift towards the production of hip-hop texts (music, literature, film, dance, etc.) that acknowledge practitioners' minds and spirits and laud their development and protection as well. Because Maslow's Hierarchy needs postmodern revisions that recognize psychological and emotional wellbeing as just as important as, and interconnected with, physical wellbeing (i.e., What role does food security play when one is too depressed, or anxious over their fragmented self, to eat? What role does fair housing policy play when one hates the constructions of their own mind and body?)

There are too few hip-hop texts that echo Kendrick Lamar's declaration, in his song, "i," of, "I love myself!" There are too few messages in the vein of Erykah Badu singing, "But I'll just let it go and / Be, be, be me." But those of us with vulnerable minds (and bodies, every one susceptible to physical deaths) need these texts to balance out the others (some enforced from without, others of our own creation) that break our hearts and names and relationships into less than words or sounds. 


\section{Don't Push Me}

I come at writing hip-hop like Grandmaster Flash and the Furious Five hand-delivering “The Message," all, "Don't push me cuz' I'm close to the edge / I'm tryin' not to lose my head." With a primary focus on the fear of losing it.

Posted up on the railing of the Brooklyn Bridge with a broken New York State of Mind, weighing my options. Imperial pain. Takeover ambition. Like, "Gimme the loot, gimme the loot / I'm a bad man." I want everything that isn't mine and then some.

No, not the Big Apple, it's a displaced mind state, floating disconnected and suspicious in Anywhere, AmeriKKKa. The small population you'd expect, the same tight budget and closed doors. Faith in the unseen. Where I write direct from Public Enemy's Terrordome. Shaky, fear inflected penmanship.

And I'm coming back at it again, still, like 50 Cent now, more outlandish and contemporary, all, "Right now I'm on the edge / So don't' push me.” Desperate-headed and selfdestructive. Double-daring who knows what. Because, "Why not?” and, "Nothing else has worked."

So far gone.

No, I'm listening to Salt-N-Pepa's "Push It" pumping from a stereo system I bought out of pocket. Penny-pinched and deliberate. Well calculated. Fiscally sound in mind and body. Workin' up a flop sweat from worry and nerves.

No, I'm reading Sapphire's Push in the plush waiting room at a psychiatrist's office, flipping out over the pages and pain after pain. "Them letters make up words. Them words everything." I want those too, greedy and spoiled alone. "Gimme the lit, Gimme the lit / I'm a bad man." Willing to plagiarize a last will and testament if it means getting the words right. 
No, Pusha T is on the radio, and I'm feeling GOOD and placeboed. No, "Pusherman" is on the radio, and I'm feeling good and placeboed. I come at writing hip-hop like every essay is titled “Pain Recognize Pain, and You're Lookin' a Little Unfamiliar." I push out pages like they're friends. I push away pages like they're best friends.

I can only write hip-hop while listening to Whodini ask "Friends / How many of us have them?" I can only write hip-hop while listening to Talib Kweli cover the Beatles' "Eleanor Rigby" on the MC's "Lonely People." I can only write hip-hop while listening to Reflection Eternal, "Becuh-cuh, becuh-cuh, because I'm paranoid." I keep my best hip-hop writing lying on a table in the panic room built into our basement.

I write hip-hop afraid and hidden. 


\section{Remapping Hip-Hop Writing}

Resources like Leta Hendricks's “Getting Hip to the Hop: A Rap

Bibliography/Discography” and Gail Hilson Woldu's “The Kaleidoscope of Writing on Hip-Hop Culture" are critical pieces of hip-hop historiography because they document where hip-hop writing has been in the past. And without acknowledging and learning from this written past, without recognizing the scope and dynamic subject matter of what could be considered a countercultural canon of hip-hop writing, aspiring hip-hop writers can't imagine a future for their work. It's a “don't-know-where-you're-going-till-you-know-where-you've-been” situation. To know what we need to write, we have to know what's already been written. And so much useful writing on hip-hop already exists in the scholarly and journalistic worlds.

Hendricks's and Woldu's works offer meticulously curated bibliographies of hip-hop artifacts divided by genre and medium (Woldu, for example, categorizes texts written by “Academics," "Journalists and Cultural Critics," and "Devotees"). The collected titles they present are pulled from monographs, anthologies, scholarly journal articles, essays, popular magazines and newspapers, and multimedia texts, with publication dates ranging from hip-hop writing's introduction in the early-1980s to its present incarnations in print and digital formats. The authors' bibliographies and analytical commentaries offer hip-hop readers and writers a roadmap of popular and academic hip-hop texts that, if followed, leads to a more complete understanding of hip-hop as a multifaceted culture and academic field of study. But it is emerging hip-hop writers' responsibility to expand upon and edit this pre-existing roadmap by first paying respect to the work of cultural pioneers, and then offering our own checkpoints, shortcuts, and reroutes of hip-hop thought. 
Because while Woldu is confident about the direction of hip-hop writing's future, I'm more hesitant about where it's headed. For example, where is all the creative and hybrid-genre writing that is inspired by hip-hop, and why isn't it receiving more popular and scholarly attention? Outside of a handful of fairly well known hip-hop-themed anthologies, novels, and poetry collections, it's hard to find and access literary work whose authors want their writing to function artistically the way hip-hop music (DJing and MCing) functions. Where are all the hiphop novels? Where are all the hip-hop poems? Where are all the hip-hop memoirs and lyric essays? And, perhaps as an extension of these questions, where are all the academics and cultural critics and artists who can imagine and theorize what makes hip-hop literature especially "hiphop" and "literary?"

Thanks to Hendricks, Woldu, and other researchers who take the time to build extensive bibliographies into their hip-hop writing projects, readers and writers know where to locate excellent examples of hip-hop scholarship and journalism that span the last four decades. But hip-hop writing has to move beyond these more traditional genres if it wants to reach broader audiences and stimulate further artistic and academic growth.

I imagine a literary landscape where genres of hip-hop writing (both critical and creative) begin to blur and speak to each other, where hip-hop heads (and outsiders) are drawn to hip-hop writing because it exhibits the same aesthetics and intentions as the other traditional hip-hop Elements they love. Where readers read hip-hop in ways similar to how they would perform or participate in hip-hop aurally, vocally, visually, and kinetically. I imagine hip-hop writing sampling and remixing itself and other texts, making something out of nothing (with style), and constantly revising and reinventing itself. Because if it doesn't, it can't call itself hip-hop writing moving forward. 


\section{Problem \#2}

Name one good thing Evan Nave has done to support the hip-hop community he claims to love so much—with a focus on the "doing." As in action. As in participation. Just yesterday I saw him through the bay window of his apartment taking a nap on the living room couch like nothing even mattered at all. While a perfectly good copy of Tricia Rose's Black Noise: Rap Music and Black Culture in Contemporary America sat unused on his bookshelf. With an old crease down the spine like he'd read what he needed years ago and left it at that.

And where was he at the last Black Lives Matter chapter meeting? Activism implies activity, and artistry implies sustained art creation for public consumption. So when was the last time you read any of his published work in The Source or African American Review or put out as a mass paperback from Third World Press? He's no "artivist" in the way M. Asante Jr. demands all real hip-hoppers be. He's no hip-hop scholar like Murray Forman or Mickey Hess. He drinks in hip-hop trivia hot like English Breakfast Tea (straight imperialist exploitation) and expects to win the grand prize on an I Know Black People game show spoof.

But memorizing lyrics and recalling album release dates ain't real hip-hop. Evan Nave is nothing more than a CD collection with a pen, unworthy even to hold the deep black ink. 


\section{Reel and Real and Surreal}

In his book It's Bigger Than Hip Hop, post-hip-hop scholar MK Asante, Jr., critiques representations of Blackness in contemporary rap culture and situates these representations within the long history of racist, exploitative, white-controlled American mass media. Importantly, he distinguishes between "real" representations of Black American life and culture (characterized by creators' profound understandings of the complexities of human existence within a sociopolitical reality dominated by white supremacy and oppression) and "reel" representations of Black American life and culture (characterized in broad strokes by cooptations of antebellum racist archetypes that normalize hegemonic power structures, that depict African American women as hypersexualized Sapphires or docile Mammies and African American men as hypersexualized brutes or docile Uncle Toms).

Where the "real" might call upon knowledge of and respect for African American history, sociology, politics, religion, and art, the "reel" is marked by ignorant, hyperracialized melodrama meant to present Black culture as pathological monolith (Asante 17). "Real" is W.E.B. Du Bois, Spike Lee, and jazz; "reel" is Harriet Beecher Stowe, Tyler Perry, and gangsta rap. "Real" is Roots and the poetry/songs of Gil Scott-Heron; "Reel" is Shaft and any of the "B Movies" Gil Scott-Heron warns us about in his collection Now and Then.

Asante's observations are vital, as he notes that racial (mis)representations in America have been and continue to be matters of life and death. The "real" fosters Black self-love, promotes community uplift, and pushes for polycultural peace and respect for cultural difference; the "reel" perpetuates messages of Black self-hatred, justifies and rationalizes white supremacist policies, and encourages oppression, segregation, and racial animosity and violence (Asante 20). The argument is clear: there needs to be more, varied "real" representations of Blackness in 
mainstream media, and the dangerous "reel" representations of Blackness need to be confronted, challenged, and ultimately eliminated and replaced with the more progressive "real."

And the "reel" doesn't get much "reeler" than it does when it's played out in the mainstream commercial rap industry, where Black Jack Johnson-style hypermasculinity, violence, misogyny (almost exclusively directed towards Sapphire characters), and homophobia sell big. Put another way, as Chuck D posits in Byron Hurt's film Hip-Hop: Beyond Beats and Rhymes, the rap industry survives and thrives on the production and marketing of stereotypes that promote "Black death," be the death physical, emotional, psychological, social, or spiritual. And, as Asante reminds us, since the vast majority of rappers are Black, and "the primary consumers of rap music" are "white teenage boys" commercial rap too often becomes a nasty transaction: "real" white money (in dollars and cents) for performances of "reel" Black culture (25). The dangerous payoff being white boys raised on "reelness" growing up into white men who uphold and perpetuate the white supremacist policies and institutional power structures designed to oppress people of color. Mistaking the "reel" they think they know for the "real" that actually is.

This, in part, perpetuating the cycle that keeps the "reel" alive in American culture and politics.

But while I recognize the potential threats of the "reel," and have real respect and love for the "real," I'm not comfortable with the real/reel binary Asante puts in place, mainly because it eliminates any possibility of combining/clashing the "reel" and "real" in provocative, and I believe necessary, hybridized rap-influenced art. Just as author Danyel Smith doesn't want to read and write in a literary world that only includes highbrow African-American literature at the expense of excluding lower-brow "street lit" ("I want—and I think we should all demand—ALL 
OF IT," Smith says), I don't want to create and engage with hip-hop art in a cultural sphere so intent on proliferating the reelless-"real" (the elusive "authentic" Blackness) that artists ignore the significance, the potential to signify, of the "reel" (Smith 194). The "real," the "reel," I want ALL OF IT, if for no other reason than "reel" Blackness is a creation of "real" American culture in all its contradictions and inadequacies. In pursuit of the "real," I don't want to ignore the historical reality of the American creation of the "reel." I don't want to hide the taboo, lowbrow "reel" behind the more righteous and socially acceptable "real."

Instead, I want rap-influenced artists to complicate and blur the reel/real into what I will call Surreel hip-hop art—an aesthetic that flips the script on perceived and performed racial identity and reimagines the fallout of each. I see the Surreel drawing from both the "real" and the "reel" in Black culture, creating meaningful juxtapositions that challenge readers/viewers/witnesses to constantly situate and resituate their conceptions of racial identity in America. The potential strength of the Surreel is its refusal to conform to either racist stereotypes or politics of respectability in its presentation of race; the Surreel artist refuses to pretend not to know about the central roles stereotypes and politics play in formations of American racial identities. In my vision, there is an openness to the Surreel, an acceptance of contradictory cultural codes, that is missing from the "real" or the "real."

But I believe it is this openness, and Surreel writers' and readers' subsequent vulnerabilities, that creates space for progressive dialogues about race, racism, and racial justice in American culture. 


\section{Incomprehensibility}

The cliché is old white people not understanding or appreciating rap sounds and hollering at the young ones to turn them down or, better yet, off. There is a value claim inherent in these demands: the only things worth listening to, worth really hearing, are those sounds that immediately or already make sense, those sounds that immediately or already relate to and reinforce the narratives one lives by or identifies with. Any other sounds are a waste of time and further consideration, a waste, a garbage to be taken away by faceless bodies first thing Monday morning and never thought of again.

There is something to the "turn off that racket" cliché, though. Rap can be difficult sounds to take in and hear, really make meaning of and respect, regardless of the color of the listening ears. Like Public Enemy front man Chuck D once said of hip-hop music, in an interview with John Leland, "It's music to play loud. It deals with loudness. It deals with noise" (79) The militant MC goes on to say, "This is not a music that you can go home and kick up your feet and listen to. This is music that requires activity" (Leland 79). This final statement begging the question, "What are people supposed to do with and as a result of hearing, hip-hop 'noise'?" If rap languages aren't to be taken sitting down, where are they supposed to lead us? And what are we supposed to do when we get there?

The act of "going" might very well mean being lead towards more critical thinking practices regarding Othered cultures, and the destination might actually be a state of political and aesthetic consciousness. If we're ready to work for them.

Because hip-hop demands of its witnesses a dedication to decoding the difficulties loudly woven into rap lyrics. It demands listeners pay reverent attention, actively making intertextual connections between hip-hop texts and other sources of African-American history, art, and 
popular culture, as well as twisting out MCs' Rubik's cube-style metaphors and wordplay until lyrics line up meaningfully in one's mind. Imani Perry, author of "My Mic Sound Nice: Art, Community, and Consciousness" writes, "Difficulty is a strategy in hip hop, both in terms of words, which are fast and hard to understand if you are not privy to the hip hop community, and of demands for an authentic personal connection to hip hop and its geography, the hood. Difficulty is a cultural and political strategy, as well as an ideological one" (511).

I would add that embracing and engaging with hip-hop texts' difficulties are also political and ideological moves. How (Whether?) one hears and situates oneself to rap texts and, as an extension, the sociopolitical realities of those who have created these hip-hop noises, says something about one's investment in hip-hop culture. What one allows oneself to hear and how one works to make meaning for oneself despite (or out of respect for) the texts' difficulties, speaks to the character of the hip-hop witness.

And there are value claims inherent in hearing and working through texts one finds difficult or unclear. Perry quotes cultural critic Trinh Minh-ha who states, "To write clearly one must incessantly prune, eliminate, forbid, purge, purify; in other words practice what may be called an ablution of language" (qtd. in Perry 511). Hip-hop artists, in creating their complex, multifaceted texts, use linguistic and performative difficulties as modes of resistance to dominant, more mainstream (white, bourgeois, Puritanical, etc.), notions of clarity, appropriateness, politeness, and communicability. These artists are not afraid or ashamed to speak, loudly, of and to the culturally forbidden, the socially unacceptable, the audaciously unclean or taboo. He who has ears to hear, let him hear. And she who doesn't be damned. 
Hip-hop texts, then, ask which side one is on, what one is willing to (mis)understand, and how hard one is willing to work to support and represent a cultural tradition steeped in racial, economic, and political struggle.

To turn down the difficult sounds is to disengage and disassociate from the culture and the struggles as well as the potentials for progressive change. But to turn up the noise, to revel in the difficulties as opportunities for personal and political revisions, is to position oneself to truly better hear and move. 


\section{Problem \#3}

Look at Evan Nave trying to be Gil Scott-Heron writing Now and Then, or worse, The Nigger Factory, so bad it almost kills him. Word on the street is he bought a set of Meinl bongo drums and has started memorizing the lyrics to "No Knock" as shtick, as shit-talking to himself. To anyone who'll listen. Trying to grow an Afro out his jaw. Trying to be that real suburban troubadour. Look at him call on Lady Day and John Coltrane to wash him away like they owe him something. When they don't speak the same language. Look at him try to conjugate. Try to starve himself into string bean for bell bottoms and pendants. Too dry-mouthed to sing off key. Look at him try to mix mediums. Look in between the sites of writing sounds and find him thinking like a real soldier intellectual. He's made up a notation for the sounds. He's made his own pathetic alphabet. Look at him trying to recreate the feeling. Watch him amateur and really try to sell it. 


\section{Hip-Hop Literate}

Susan Weinstein uses her article "A Love for the Thing: The Pleasures of Rap as a Literate Practice" to argue 1) for hip-hop as its own sociocultural literacy and 2) for the primacy of pleasure within any literate activity (274). These arguments are critical not only because they boldly position hip-hop texts within the realm of English Studies (i.e., as artifacts worthy of scholarly attention) instead of relegating them to "lowbrow" mainstream consumer culturestatus, but also because they promote the empowering notion that writing is validated not when it is sanctioned by authoritative bodies, but rather when it offers significant satisfaction (based in self-expression and community inclusion) to its creators and audiences.

It's like this:

Rap is its own discourse community, made up of multiple, varied authors, texts, and witnesses. One participates in the hip-hop discourse community by creating and critically engaging with hip-hop texts (e.g., recorded or freestyle rap lyrics, graffiti, and I argue, hip-hop journalism, scholarship, and literature like fiction, creative nonfiction, poetry, and drama). If you don't contribute to the hip-hop corpus with your own language, you're not a part of the discourse community; hip-hop's not for you. If you don't critically read/witness hip-hop language, if you don't welcome it into your world, show it around and build it a permanent home, you're not a part of the discourse community-hip-hop's not for you. You're illiterate.

Membership in the discourse community means having stakes in hip-hop's future as well as possessing vested interests in the lives and wellbeing of other hip-hoppers. It means not just talking(/reading/listening) about it, but being about it. Hip-hop community membership means putting something of yourself on the line every time you write/speak/read/listen to hip-hop-hiphop citizenship is a zero-sum game. 
Inclusion in the hip-hop discourse community is accompanied by the pleasures of being part of a literary and cultural body bigger than your own skin (Weinstein 275). You are not alone with your body anymore. Membership means identifying with other hip-hoppers, the longer/larger cultural history, and the back catalog of hip-hop texts (Weinstein 276). You're in it as a part of it.

Inclusion also opens space for identity expression, experimentation, and fragmentation. Hip-hoppers build and perform personas and alter egos who can do their authors' verbal biddings (Weinstein 277). I can write myself into existence, manipulate others' perceptions/receptions of who said what and when (and to/for whom); I can make myself disappear while telling a story of how it all went down (Weinstein 278). I can trick you something awful and get away with it.

Inclusion allows members a discursive playground where they can, as KRS-ONE might put it, "edutain"/escape themselves in a community of trusted artist-allies (Weinstein 279). Where I exist in the economy world to work and spend efficiently, I exist in the hip-hop discourse to play word games that move. Everything is free. We made up the rules, and they're subject to change. If the games don't make sense, they're not for you. You're watching me play, and if you're not going to join, the game's not for you. Go back to work. Find something else to speak to. There are other discourses out there to lure you in.

All of this is to say that experiencing and claiming discursive pleasure, especially if it's been deprived long enough, are political acts. Co-creating pleasure and caring about the pleasure of others (instead of gettin' yours while the gettin's good) are political acts. Creating towards community and holding onto those creators and their creations like they're the only language are political acts. 
And if you don't believe me, try taking hip-hop away from a true head and see what happens. 


\section{Problem \#6}

I walked in on Evan Nave while he was having a nervous breakdown in the first-floor bathroom of Third World Press's editorial offices. Puking up stress between pitches of his novel, Bootleg Ghetto Pass Revoked, to some senior staff who weren't having it. He slammed the door in my face and retched pathetic apologies about how it had nothing to do with race. Made me promise him that I knew none of it had anything to do with race. Like we weren't deep in the South Side and old black women hadn't picked him out, odd, from between neighborhood blinds. I lied a promise and waited outside while he called his dad on a cellphone and begged for a ride home. He cried, "I am not Gwendolyn Brooks." It was the ugly truth, and I heard him sob, desperate like blues, until he knew for sure someone was coming to swoop him up. Until he believed it enough to breathe again. Then he opened the bathroom door slow, smiled weak and inoffensive through swollen eyes, wiped his mouth, and nodded a flimsy brotherhood towards me. I tried to nod back but couldn't. It would have been as dishonest as his artistic intentions, and I felt like at least one of us needed to keep it real. 


\section{Rap Masks}

After reading Mickey Hess’s “Metal Faces, Rap Masks: Identity and Resistance in Hip Hop's Persona Artist," I've started writing hip-hop incognito. Like, "Now you read me, now you don't." Or, you can see and read but not recognize the author. You couldn't pick him out of a criminal lineup or say for sure. You couldn't pin the words on him beyond a reasonable doubt.

I write behind a mask to convince us I know what I'm writing about. You and me both. Because neither of us is buying it based solely on mainstream credentials and an academic ability to signify. Because, Hess argues, "A successful performance of hip-hop authenticity is one which positions the artist as experienced knower" (297). Hip-hop demands the realest, the most authentic artist I can perform and call the "real" me. Or I can be "reel" as long as I trick it out as “real.” Back it up with bravado and red herrings. Bait and (code)switch. Because hip-hoppers demand authentic realness from their artists one way or another.

And the consequences of inauthenticity, of not satisfactorily meeting hip-hoppers' reality demands (like you're being held for identity ransom), are persona non grata to the utmost. Like, "I think, therefore I am" in reverse: "You think, therefore I am who you think I am." And if you think I'm inauthentic, it's over. Inauthentic like Vanilla Ice gunplay allegations or Mark Wahlberg as the Funky Bunch front man (When was the last time you heard these characters speak to or for the Hip-Hop Nation?) Played out and busted. And no one wants to be busted. Called out. No one wants the audience abandonment and subsequent social irrelevance that inevitably accompany getting called out as inauthentic.

The realest get exalted. The reelest get exiled.

But that real/reel split is as political and mythological as it is autobiographical and artistic. The realest are the realest because they convince you they're real enough to believe 
them. Real wouldn't lie to you, now would it? The realest have experienced enough realness, they’ve known enough realness, to be considered real "experienced knowers" of hip-hop realness. (Even though it's possible some "experienced knowers" might not know much beyond how to hustle the reel they're selling as real. Hoping folks will buy it and call it the real, enough for it to might as well be, anyways.)

And the thing no one tells you from jump is that inauthenticity equals a mandatory minimum sentence of silence. If you're considered a "not knower" of hip-hop culture, no one wants to hear your noise. Because what could you possibly know? So keep your nonsense to yourself, silent out there alone. And lonely silence is discourse death. Like, if you can't be a contributor, you're stuck consuming the kickback conversations and performing knowledge of hip-hop hearsay; it doesn't get much cornier than that, and the left-out loop goes on and on till the break of dawn.

I write hip-hop to stay awake and stay up.

But I also can't afford the risk of misinterpretation. The psychosocial threat of alienation. I write hip-hop behind a mask to be more and less myself with you. To split myself in two, so there's more of us. I write myself and the mask differently to build a crowd. I write myself in two and reconcile on the page as a way of moving the crowd. The mask offers an opportunity to split and reconcile as much as it takes. Until I'm less alone with you. Until we might be a hiphop community performing discourse together.

The is mask my way of fooling myself into a community that doesn't talk back.

The mask is made out of 24-karat fool's gold. I write hip-hop alchemy. I have to because I might not know and have experienced enough real hip-hop to be considered an "experienced [hip-hop] knower" by enough real hip-hoppers to count. And even if I have adequate hip-hop 
experience, knowledge, and character references, hip-hop realness arbiters often utilize flimsy algorithms based in language and unquantifiables like family history, urban-based anecdotes, racial revelations, hip-hop trivia, struggles with The Man, lyrical skills, shoe cleanliness, car make and model and rim size, and artistic or political and/or economic intentions. And I don't trust the numbers. I could never do the math.

Nothing ever adds up. 


\section{Burnt}

I read somewhere that the Romantic composer Johannes Brahms burnt every original composition he thought didn't measure up to Beethoven's lifework. Legendary standards. Like no one else needed to hear it if it didn’t pass Brahms's extreme self-evaluations or prove pleasing to Beethoven's dead, deaf ears. We'll never know what music we didn't hear from Brahms. There's a sense of sonic loss that comes with this. All the sounds we don't know we don't know.

But I like the "all or nothing" feel and have started burning my writing if it isn't Tupac Shakur spitting or Cornel West waving his loving arms over a pulpit pedestal. If it isn't a Southern soul sample or a dirty microphone covered in furious DNA. If it isn't worthy of inclusion in Amiri Baraka and Larry Neal's Black Fire or the Harlem Renaissance literary magazine Fire!!. If it isn't hot enough to burn and scar.

You can't read what I burn.

And I burn almost everything I write.

I keep the heaps of ashes under my writing desk and scoop handfuls into my palms before I go to work each morning. Spit into the ashes until they reconstitute as a black edited paste.

Smear the paste on my face and forearms. Wear the unworthy words as a humiliated disguise. I go to work written over with failure. The ritual a throwback to a Hebrew expression of mourning, pulled straight from the Good Book.

No, the ritual is a godless blackface performance critiqued in Kareem R. Muhammad's “Pearly Whites: Minstrelsy’s Connection to Contemporary Rap Music.” I begin every new writing project like I've just finished reading Jason Rodriquez's “Color-Blind Ideology and the Cultural Appropriation of Hip-Hop" again for the first time. My skin becomes a reminder and a warning. I write to warn myself about skin and color. 
I write to remind myself to wash the ash off before I leave the house, to read white to everyone at the grocery store, to pick up another box of matches from the home improvement aisle. The checkout lady recognizes the meekness in my white hands and features, reads them as a cultural inability to ignite and explode. She'll never read what I burn.

I heard somewhere that the legendary comedian Richard Pryor lit himself on fire trying to get high. Charred scar tissue on his chest and neck—no joke. He cracked on himself about the burning, used it as an off-color conversation starter. He tried to build something out of the flames, make new material. He said something to start something going.

I write ashes. I hide behind ashes so no one will start anything with me. 


\section{Should Have Been a Freestyle Rapper}

Then I could consistently go off the top of the dome to the beat without having to worry about how the words I spit could linger and live on after the cipher disintegrates away and comes back for me again as white ghosts. Then, I would have the cipher to begin with, and I could take in their faces and listen to their voices cycle through my own and mine with theirs as communal ritual chant of salvation and fear. Their mouths and bodies could justify and proof-positive my own as an argument for something bigger than us without knowing what. That way, when I become overwhelmed by the boogieman of The Bigger Than Us out there somewhere (it's psychopolitical and existential, for real), I could look at the cipher as evidence that I wasn't simply sending singing telegrams into the sky for no one-as no one.

I should have been a b-boy. I'd be like the ones Sally Banes writes about in "Physical Graffiti: Breaking is Hard to Do.” Then I could break battle with my crew and shout to whatever Power-That-Be that's peeping us, like they did, "We're not fighting. We're dancing!" (Banes 7). Maybe if I was one of them, legendary breakers like Crazy Legs or Frosty Freeze or somebody down could vouch for me as me trying to get on the good foot. At least then I would have them to step and sweat to, anxiety as energy to burn into something like myself or a baddd reputation.

I should have been a graffiti writer. One from the bygone Style Wars days when they started at the Writer's Bench at Grand Concourse in the Bronx, trading stories and Polaroids of their latest bombs to blow up. We could steal spray paint cans from corner stores with the extra space in the waist of my blue jeans. LADY PINK could teach me something about the ferocity of cyclone fences around the train yards and lay-ups (far away from my living room television drama with Wild Style scenes). SKEME could introduce me to his mother (if she's still with us), and we could try to convince her of our names together. Her stubbornness might be like a joke 
we keep between us like the spaces between the train cars when we show up to show out and be seen.

I should have been a DJ. One with the deepest milk crates on the block and stereo speakers from my dad's den. He could loan them to me when I prove responsible, man enough for him. That could mean something to him he could show in a look. Without the jacked power. Without a set of AA-batteries. I could siphon juice off a city lamppost until the break of dawn. I could be that master of records and mix without apologizing. The sounds demanding a new name and legacy to be forgotten and buried, years later, in a suburban cemetery, in an unmarked grave. But while the sound lived I would be alive there, and big. I could be that someone moving the crowd. The crowd as proof of me. 


\section{Problem \#5}

I saw Evan Nave wide-awake on a Sunday night, trying to fall asleep to a recording of Malcolm X's "Ballot or the Bullet" speech like it was a nursery rhyme. An old drunk outside his bedroom window listening to R\&B in his Buick, only opening the driver's door to hack and puke in the alley. I saw him awake in a way he couldn't write and perform later for a respectable crowd of peers. Through the broken screen hung on a window, his teeth brushed clean white and personal. An even guiltier conscience. I saw him finally sleep the enemy sleep and dream the dream where he loses his voice and has to whisper acquiescence like he ought to when he's awake. 


\section{Choke}

Remember the opening scene of the movie 8 Mile? Where Eminem as Jimmy "B-Rabbit" Smith, Jr. is in a freestyle battle with some dude at the shelter. And the other dude goes first before B-Rabbit after a coin flip and says, "This is hip-hop / you don't belong / you're a tourist" and everyone in the shelter goes crazy because of the different colors of their skins.

And after the crowd settles down the first dude hands the black microphone to Eminem as white-man-in-the-'hood, and his semi-autobiographical "B-Rabbit"-self hears the shelter DJ drop the beat somewhere behind him on the impromptu stage. And whiteboy B-Rabbit holds the mic up to his mouth for 4 bars, 8 bars, 16 bars of dub-side beat. And nothing-language happens in front of everyone.

Remember when "He opens his mouth / but the words won't come out"? And still no more words come out of him.

Remember when the crowd starts chanting, "Choke! Choke! Choke!” and later, when his ex-girlfriend lets him know that, “Everybody’s talkin' about it, how you froze up and got booed off stage"? She laughs and mocks, her body shivering like his was before in the shelter. And he screams, "Fuck you, Janeane!" on the sidewalk outside the factory because he's humiliated that he can talk now but not then when it counted. That in a moment where real-life rap language was demanded of him, he couldn't say a word. He silenced in the moment - the way a real rapper never would. Real hip-hoppers would never let the say-something moment slip, knowing damn well that language is just about all they have in the world anyway.

I watched the scene for the first time, and after awhile of thanking God I wasn't Em as Rabbit in that moment (I have nightmares of voiceless throats, mostly when I'm dreaming face- 
to-face with something or someone I fear), I started thinking of choking silence as its own artwhat could be said, but isn't, as its own minimalist hip-hop text.

Like, was Mims serious when he rhymed, “This is why I'm hot / I don't gotta rap / I could sell a mil(lion) sayin' nothin' on the track"? Could a rap be minutes of nothing-language, vocal silence over a breakbeat, and still be called a rap?

Because if it could, maybe choking in the language-moment shouldn't be thought of as humiliating, as a missed opportunity, but as itself an opportunity to listen to other members of the hip-hop community (or the voices inside oneself) who can only be heard when you're tongue-tied. Maybe B-Rabbit's silence could be heard as it's own hip-hop version of John Cage's conceptual 4'33'. Where the music is everything you weren't expecting to hear but is still there anyway.

Maybe a rapper who doesn't rap is performing their own important, conscious version of listening-music, where their inability/refusal to vocalize demands a similar listening response from the audience. Maybe a b-girl is "dancing" in the milliseconds she takes to breath before taking it to the ground, even if there aren't words for the choreography of pre-movement. Is a DJ a DJ before the records start to spin?

Closer to home, I'm thinking maybe a hip-hop writer with writer's block is actually performing an important written silence on blank pages. I'm wondering about the literary value of these pages. Can they be assessed for their potential hip-hop energy, rather than the kinetic pen across the page?

How does the wise hip-hopper know when it's the right time to write, and when it's the right time to let the beat run and listen to hear what happens? 


\section{Bleaching}

I watched the 2014 documentary Bleaching Black Culture with a bottle of Clorox sitting on the coffee table. The film threw up definitions of "cultural theft" and "cultural misappropriation," and I took careful notes on a sheet of legal pad paper with "Never Do" written in bold letters across the top line. All while I lip-synced Robin Thicke and Justin Timberlake songs, knowing better. Harmless multitasking. All while I remembered the time I translated T.I. into Standard Written English for a group of white people to see what they'd do. Like it was my place to conjugate. And the white people were so impressed they laughed and called it a bilingualism.

I mouthed apologies for it all while I took even more careful notes.

And the pundits in Bleaching didn't share the same shame in their faces and shoulders when they spoke. I tried to hide. I hunched over in the couch so they couldn't see me. I put on the posture of someone who knows better. They said the word "borrow." They said the stinging word, "steal." They said the word "flattery." They said the word "respect," loose and unsuspecting. They said the word "mockery," and I smelled the Clorox uncapped from the coffee table. The fumes from the bottle blurred the TV screen, and I felt a contact high, especially safe and selfish. I could turn the film off anytime I wanted and forget it ever happened. White it out from memory.

Bleach is strong and holds the promise to erase.

When the credits rolled I couldn't hunch over any deeper to get away from the racial implications. Indicted alone in my living room. The evidence of co-opt showed in my white hands ashamed red. I felt looked at and see through. No substance. I looked at my careful notes instead and wondered what would happen if I poured the Clorox evenly over my handwriting. If 
the ink would oxidize and evaporate out the open window. Until the paper was blank with potential again. Back to neutral. I felt the urge to bleach everything I've ever written to see if it would hold up. Make the whole thing a litmus test, and whatever showed up afterward would be authentic and honest. I felt the uncontrollable urge to fill the barrels of my pens with bleach, so nothing would ever show up on paper again. Unaccountable. So people could see the damp pages as effort and cowardice, and I could still call myself a writer with the blank pages to prove it. 


\section{Writing With White}

Whiteness can read bland or blank, an absence best represented by an empty sheet of notebook paper or a half-empty glass of sour milk. Or, more vital, white can be bloodless, faint. That which has known life and lost it (Dyer 59). The unknown, unfilled, or undead.

The price of privilege in the land of opportunity.

Hip-hop, on the other hand, promises fresh-to-death life. Narratives of lack that function as long-distance reminders of what white takes for granted. A style and (heart)beat anything but absent. Something with a brand new flavor in your ear.

Yes, white kids come to hip-hop to touch "the fantasy of being a powerful player in a cool black world" (Als 205). It's part identity performance through cultural appropriation and mass consumption. But it's also part pitiable attempt to fill an often unconscious ethnically ambiguous void. Where make-believe miscegenation is only a rap record away.

Where, "If you're white, you're alright," doesn't sound as good with the bass turned down. But not so bad as to start rocking the boat.

I tell myself stories about not being the average white kid black and white scholars bemoan when they write about rap culture being uprooted and transplanted to suburban front lawns. I freestyle novel-length hip-hop stories to prove I can carry the weight of a tune on my own two feet.

And the truth is, I didn't jack hip-hop to call blackness my own. Honest. But I do write hip-hop to question what's mine. To fill blank notebooks beyond a shadow of a doubt. To feel a sense of fullness the opposite of white.

And in the end I mostly feel full of shit. Regardless of the storytelling and counterscholarship. I'm not buying what I'm selling - the cultural costs too high to pay out of 
pocket. But even the mess in me, the heavy-handed bullshit, the selfish maybe-minstrel heaviness, sounds better than empty white noise. 


\section{Mad World}

In his excellent treatment “"The People Inside My Head, Too’: Madness, Black

Womanhood, and the Radical Performance of Lauryn Hill," La Marr Jurelle Bruce examines the eponymous turn-of-the- $21^{\text {st }}$-century hip-hop genius's embodiment and performance of mental illness as a radical digression from normative psychological states.

The author allows Ms. Hill to be as mad/bad as she wants to be.

And in doing so, Bruce offers one of the most thoughtful analyses of the intersections between mental health rhetorics and hip-hop studies. A breakdown, say, of what goes on inside some hip-hop heads when they listen to "Buggin' Out" by A Tribe Called Quest on endless repeat. A shout out to those whose thought-lives embrace what MC Talib Kweli calls, "The beautiful struggle." A naming of the often-invisible struggles and beauties one encounters while battling for her own mind.

While the article covers the breadth of Hill's tumultuous career, from her early years with hip-hop trio The Fugees, to the 1998 release of her tour de force The Miseducation of Lauryn Hill, through her anti-Vatican critiques in 2003, and up to her present status as reclusive prophetess/mother, I'm most interested in Bruce's read of where Hill's head was at during and shortly after the recording of her MTV Unplugged No 2.0 album in 2001. Specifically, the author theorizes two themes of madness/degenerative internal dialogue that strike me as important when considering hip-hop as a radical, life-affirming communicative practice.

First, Bruce notes the instances in the Unplugged performance where Ms. Hill acknowledges the voices of "the people in her head" to the small live audience gathered in the MTV studios (375). The artist is conscious of these inner voices and bold enough to mention them publically; she candidly hints that they might be symptomatic of a dissociative mental state. 
Hill is hearing things others can't hear. But instead of hiding or ignoring the voices, she playfully lets others in on the circumstances of her possible madness. In doing so, she performs the role of mad artist.

Rather than copping out and dismissing Ms. Hill as schizophrenic, instead of diagnosing her polyvocal performance as strange or sick (as so many other music critics did at the time), Bruce sees in the open acknowledgement of "psychosocial alterity" an opportunity to imagine the possibility that Hill is performing for an inner public the live audience members in attendance, and future Unplugged album listeners, know not of (372). In speaking to the presence of her inner voices, Ms. Hill reminds us of the possibility that "there are other constituencies who warrant her attention," a "symbolic counterpublic" in her mind that has nothing to do with us as listeners or our expectations of how an artist should think, behave, or create (Bruce 375). She's rapping/singing on a different level, to otherworldly criticisms beyond our comprehension.

Bruce continues his important theoretical work by identifying "the voices" in Hill's head as evidence of what he calls "a talking wound," or, "a trauma that clamors again and again in the consciousness of the victim, that echoes like a sinister refrain, that inflicts hurt with each iteration" (376). Mental illness speaks, makes itself known and heard to its host, beyond the "voices" that function as specifically schizophrenic symptoms. Mental illness refuses to be silent; it chides, provokes, and humiliates in semi-audible tones outsiders can't hear and wouldn't understand.

In Ms. Hill's performance of madness, we witness a hip-hopper's reaction to her talking wound: she talks back. She takes the voices in her head, the ones that threaten her precious peace of mind, as a call, and offers hip-hop as her response (Bruce 376). Every painful, self-destructive 
call is met with a healing, artistic response. She raps/sings herself towards sanity and selfacceptance. She hip-hop's herself solid and self-aware, as evidence of survival and hope for survival.

Her hip-hop art functions as resistance to the despair mental illness elicits.

And as Bruce's work makes clear, this resistance is a political act, as confrontational and life affirming as anything hip-hoppers have put forward to date. Because hip-hop has always been about (re)inventing oneself, struggling against oppressive forces, battling. For the most part, these hip-hop struggles and battles have been against external foes (e.g., racist institutions, mainstream cultural norms, etc.). Ms. Hill's work reminds us that hip-hop can also be a weapon in the battles in and for our minds. We can use hip-hop to talk back to the voices that seek to silence and destroy us. 


\section{Fragment \#4}

Dr. Dre said, "Fuck rap / You can have it back," but I told him I didn't want it and never had it first in the first place. Finders keepers and backwards the way it's always been. Manifest destiny with a loaded gun. Treasure-hunt logic with the maps stacked like stacks of paper. Paperweighted down with gold. Dre said he knew the golden rule: whoever has the most gold records makes the rules. The rest of us follow and listen close to feel golden. The rest of us sit in the shimmer to warm ourselves and shine.

“There are days," I told him like a shrink, "where I want nothing to do with this rap shit." He nodded and wrote something psychiatric on a yellow legal pad. I went on, "Where I want to forget I ever heard rap for the first virgin time." I covered my ears, tried to protect them from the past like gold. Dre nodded more, and I noticed it was to a pair of black Beats headphones that blended in with his skull cap. I hadn't recognized him multitasking like a motherfucker. On the clock play-doctoring while writing rhymes for a track that had nothing to do with market demographics or how listeners take up black metaphors to self-diagnosis and self-medicate.

I squirmed on the reclined leather couch and felt uncatered to and loudmouthed.

Indignant as all get out. Not-white and empty handed. So I decided to keep it all even more to myself. Keep even more and hold on until someone noticed but assumed it had always been mine with how natural the taking looked. All while Dre mouthed lyrics to rhyme with "you never step in the same river twice," ignoring how white my knuckles had gotten from trying not to let go. 


\section{Writin' is Fightin'}

In his “General Introduction” to That's The Joint!: The Hip-Hop Studies Reader, coeditor Murray Forman gets bold and attempts to lay out the raison d'etre of hip-hop participation: “Individuals take up hip-hop's expressive forms in order to challenge structural authority, articulate their own agency, and define their identities in locally meaningful ways" (5). To Forman, the global hip-hop community comprised of b-boys/b-girls, DJs, MCs, graffiti writers, fashionistas, entrepreneurs, and slanguage talkers do what they do as a mix of assault on the sociopolitical status quo, declaration of self-determination, and act of self-identification within a geography of peers and antagonists.

And I say "write on" because I've seen and heard these things to be true.

I've listened to MCs like Chuck D and DJs like Terminator X use hip-hop music to defy and decry American racial politics. I've seen breakers in films like Style Wars and The Freshest Kids claim space with their bodies and dance themselves into positions of power. I've seen aerosolists use graffiti to say, as one artist does in the documentary Bomb It, "Here I am, world. I fuckin' exist."

I've borne witness to hip-hop artists using the Elements to do and be more than circumstances would have expected or allowed.

But Murray uses his Introduction to recognize another practice he believes deserves inclusion in the list of hip-hop rituals: writing. He claims, "Research and writing, whether in journalistic or academic contexts, are absolutely part of the wider hip-hop culture. Analyzing, theorizing, and writing about hip-hop are also forms of cultural labor and should accordingly be regarded as consequential facets of hip-hop" (7).

Studying hip-hop is hip-hop. 
Writing about hip-hop is hip-hop.

Writing inspired by hip-hop is hip-hop.

And this is all so important because writing hip-hop will break your heart.

Because it is lonely without a cipher to hear your rhymes and respond. It is lonely

without another b-boy to battle or a crew to back you up and exist with. It is lonely without other graff writers and the sounds of the city at night and the vandal squad chasing you out of the train yards.

Hip-hop writing does not always guarantee the same risks and rewards and instant gratification/validation as the other Elements. It does not guarantee the embodiment of a voice or sound, those visceral cultural connections.

It might, instead, guarantee you lonely in the academy library stacks long after everyone else has left. You, lonely behind the computer screen typing alone because there must be complete silence to hear what you have to write out of all your hearing and reading and witnessing. There is a loneliness that lives in writing about hip-hop community you don't have and maybe don't deserve. There is loneliness in the painstaking work it takes to prove yourself to an audience who might never read you. To mentally process everyone and everything you can possibly hip-hop to, and in the end produce yourself for a public who may not be interested in your solo projects.

I learned hip-hop with the loneliness it took to write hip-hop alone.

And now Forman comes along saying the learning and the writing is the hip-hop just as much as rhyme, scratch, spray, or break. And this has me thinking maybe the loneliness $i s$ the hip-hop, too. Which could make it all worthwhile. Because it could mean I'm alone as everything I love rather than because of it. 


\title{
CHAPTER II: BOOTLEG GHETTO PASS REVOKED
}

\author{
Sometimes life's like a drug \\ Trippin' me out and fuckin' me up \\ Makin' me what I want to be \\ And don't at the same time \\ -Talib Kweli, “7:30”
}

\begin{abstract}
"It was the most eerie experience I have ever had.
I felt alien, creepy, conspicuous, ashamed. I wanted to camouflage my white skin, and assume some protective coloration. Although, in reality, I suppose no one paid the slightest attention to me, I felt that everyone was sizing me up, regarding me with hostile eyes. It was ghastly. The strange dark faces, the suspicious eyes, the undercurrent of racial antagonism which I felt sweeping around me, the squalid streets ..."

-Wallace Thurman, Infants of the Spring
\end{abstract}

Wouldn't it be chilly with no skin on?

- "Ghost of John," Traditional American folk song

\section{Mic Check}

The 'hood was dead on arrival. Flat-lined beyond a prayer. Folks had outspoken obituary sections Scotch-taped to the insides of their windows to hide the pain of the loss they were feeling, paired with old Family Ties reruns on rabbit-eared TV sets to drown out the drone of just 
living. The wind and rain squatting over the projects didn't give a shit about privacy or prime reception, though, and beat against the panes like a schoolyard bully looking for long overdue lunch money. No one held any loose change in their taking hands, only folded up City bus maps rerouted permanently south.

Shit was going down and out.

Me and my gang were going nowhere special either, and as fast as we could with our white asses. I had gotten my greedy hands on a copy of St. John of the Cross's "Dark Night of the Soul" and couldn't give it up for nothing. I was trying to sync the Spanish verses with the beat of a Lil' Wayne sample over a boombox, until the prayer-poem stanzas lined up perfectly with the addict acolyte whimpering, "Only once the drugs are done / I feel like dying." I got hotshot philosophical.

"Is it just me," I asked, "or does the rain look like prescription strength relief at over-thecounter prices?"

Everyone fell out laughing, unbelievers in the moment of chaos.

Loosey said, "Boy, you must be crazy.” Tiger backed him up with his wild snaggleteeth. Jethro took a match to the rusty charcoal grill to barbecue a chicken cordon bleu sandwich on sourdough bread. But the nasty storm clouds threatened to put out the flames and keep us hungry for more—-before anything even got started.

All the shotgun tenements in the neighborhood wore devil smirks and thigh-high boots to tease us into wanting them bad. Rhythms from the raindrops on the roofs tapped doom music loud enough to drown out my mix, until I couldn't hear myself think.

Loosey was right because I had lost my mind on a rope. My mother said she put it by my little league baseball glove in the attic, but she was too strung out on soap opera characters and 
would-be betrayal to know the truth of it. She learned how to tell slant stories from Lot's wife in the bible, and from time to time we found her a pillar of iodized Morton salt. Antiseptic and savory.

Trixie said she had locked her diary tight with a small metal key and that my mind could not possibly be there between the pages. No way. Not even with the magic princess dust of a Walt Disney VHS tape we had wound around our mother's eyes until she didn't know our living room from Neverland. My father sat sipping slowly from a Miller High Life beer. Straight from the bottle, cold. The static scratched TV commercials made the beer bubbles into shapes of women.

My bad, he wasn't drinking a beer. In fact, I never saw him get a taste. The desires that brewed up inside him weren't there for me and Trixie to see. I call her Trixie when I really mean to say Vermont. My parents having named her after a nature trip funded by a philanthropic suburban conservatory with missionary zeal. I mean to say we called her Cindy Brady. Loosey eyed her naked body once when she had a high fever. No one could tell whose face got redder. Afterwards, our mother bought McDonald's Happy Meals for everyone to keep us from toying with cheap ideas in our heads.

\section{Track 1}

It was Jethro's idea to rob the corner gas station. At least we blamed it on him when it all went wrong in our heads. Imaginary gangster war games we could never pull off in the real world. I didn't have the brainpower to mastermind. Jethro had a bashful trigger finger. Tiger had two left feet. He tripped and burned his hands on the charcoal gridiron trying too hard to catch his fall. The Wilson neighbors had a daughter we hadn't noticed until the time was right. She 
was about our age, and we watched her sunbathe off strands of heat lightning like greedy perverts.

It was Miller Time. The Wilson's daughter was a Miller Beer bikini model in gold, and pink cheeks. She introduced herself from the next-door sidewalk under a promotional umbrella that slanted to show off her trendy Ray-Ban sunglasses and Tyra Banks forehead. We saw her supermodel potential in the way she introduced herself as Miller High Life. The smug champagne soaking our fake IDs in suds.

Cindy Brady played her bongo drums on the back steps. Her knees raw and scabbed. I saw her palms and the tips of her fingers pound out a song to heaven.

Tiger howled from his grill marks. Jethro took up as the founder and president of the neighborhood Eminem fan club. Cindy Brady's performance was the bassline of "The Real Slim Shady," where the rapper gets drunk off fast food grease and crashes his hatchback into an alley. Cindy stopped after the hook and played the bassline of "My Name Is," to reacquaint us with our birthrights. White flight and quarterly SoundScan figures. Her fingers ached in the damp air we called a spring season. The perfect weather for Elton John instead.

Tiger's purple-tinted sunglasses had a group of around-the-way high school boys swooning. The sun believed in black ghost clouds shaped like great white sharks above us and hid from the horrors of the neighborhood. All the corner boys, it was maybe seven of them, poked their butts out and whistled, "Ooo, la la la," our way. The stench of expired hamburger meat hung in the air like bait.

My mother stood in the kitchen window with cigarettes stuck up her nose. Jethro held a Klondike bar in each hand. I was bleeding from my ears and wore the look like a French summer fashion. There wasn't a t-shirt in sight. 
We compared the scraggly black and blonde hairs growing out of the bumps around our nipples. Jethro went on and on about his European heritage. I went on and on for an hour or two about my European heritage. Loosey's European heritage was never in question. He could prove it with a look. He was asleep with his Nike sneakers propped up on the squat barbecue. The flames gooed up the swoosh until it was a peace sign. Then, slowly, a skull and cross bones. Then, slowly, a spot-on portrait of a specific American president. With the fire spitting out the steady rain, and the rain right back at it.

Tiger commented on his European heritage. Cindy Brady was sucking on an ice cube from the kitchen freezer. We saw a plane take off over the next block. The kind that only flies out of the Midwest and never comes back. We could tell because where sideview mirrors might've been there were laminate stickers supporting the second-term campaign of the current American president, and slick advertisements for Quaker Oatmeal.

\section{Track 2}

Jethro drank rainwater off the bill of his three-pointed pirate hat. I ate one by one the inside of a Ritz cracker box. Miller High Life shook her lump titties in the rain. Cindy banged on her would-be titties like a bongo drum set. Loosey snored out of a nostril. I started narrating a coming of age story to the whole gang. None of the details mattered or sunk in because our puffed-out bellies were digging into the front buttons on our Dungaree blue jeans. Too much pressure to keep focus. Our thoughts lamented in the pink divots or creases caused by the denim.

Tiger couldn't resist chomping on a cheese Danish he had found in the vacant lot. My father was in the living room drinking and at the Firestone tire factory pulling a double shift. His biceps had the shimmer of a farmer tan right above the elbow from where he went to the tanning salon and wouldn't take off his thick Dickies coveralls. Father spoke his native language and the 
language forced on him from television commercials. He taught me to eat Cheetos snackchips very carefully, so as not to wake Trixie from her therapeutic naps. "Like this," he said, "so Mother won't wake up from her grave." "Like this," he said, "so we can slip sleeping Trixie back in Mother's womb, and we'll all head on over to Chuck-E-Cheese after."

I handed Loosey a Cheeto puff from a Campbell's chicken noodle soup can filled to the brim with them. He was asleep as all get out. The rain spattered on his teeth. Cindy Brady had peeled her t-shirt off because she saw Tiger do it first. Only the bumps around her nipples showed. Jethro raised his arm stiff, like to ask a question.

I said, "Yes, pupil boy."

He said, "Will the high school sissies whistle at us all afternoon, or just so long as we keep licking our lips?”

Tiger said, “They ain't no sisses, but the meanest loverboys on the block. Just look at their cropped Calvin Klein boxer shorts.”

And sure enough, all the cuties on the corner were packing heat in their elastic waistbands frayed just so. Seven pistols, one for every dimple divided by two.

A gang of low-level intellectual types rolled through in a low-rider and asked the high school sweethearts if the boys could keep something on the low. Namely, that the eggheads were sitting on a carton of bootleg anti-anxiety pills and were looking to dump them on the closest thing to a lamebrain they could find. I had never seen so much tweed and high-class snobbery from a bunch of hoods trying to make it in a pitstained world. The head honcho in the low-rider's passenger seat had grease for a handlebar moustache and pooched out his lips when he talked. All the other brainiacs were reading books on Eastern philosophy, some chic new brand of 
Marxism, and the Sports Illustrated swimsuit edition, respectively. Their glasses way down on the tips of their noses.

Greasemouth was all casual to the high school homecoming queens like, "I know sweet boys like you all must have a lot of pretty girlfriends that want to chiiill with you, and you know I got the chill pills right here." He opened up a Superman lunchbox and showed the boys Clark Kent's prescription guts. Like it was the Holy Grail or gravel or something. The boys held onto their baggy pants and ran away screaming, "No, no, not that drowsy shit! We might doze off and forget our first names, what with the brand names on the size tags in the necks of our undershirts shriveling up." They scattered like pixie dust in an all out opium den. We watched the boys scatter like table salt, just as small and white.

The low-rider idled while the brains flipped big pages. Greaseball shook his head like, "Prep kids these days," and caught me red-handed staring at him and the low-rider's spokey rims. We were all staring at the transaction failed stinky like a Breathe Right nasal strip commercial. Cindy Brady was squatting in the grass, shaking her ass like a professional cowgirl and letting the raindrops smudge her toenail polish. Loosey made his face into a crackhead down to the last detail. Tiger made up a freestyle rap about Bill O'Reilly tripping over his shoelaces and biting his tongue on the big issues. Jethro looked tired and desperate with his blue eyes. I saw everything clear, clean, through the rain. Game recognized game.

The low-rider pulled up to us bumping Elton John from the trunk speakers. Lucy in the Sky with Diamonds was over smearing coconut-scented suntan lotion on Miller High Life's boney shoulders. We were all like, "Bum ... bum ... bump!!! Ohhhh-ohhh!!!” to the beat from the truck. I had never seen so much conspicuous critical reading. Big bad boys with their elbows out, rocking tomes like they were nothing. 
I still had the flat feet I was born with. Bent in enough that my ankles touched the ground on the hips for a first dance. Cindy Brady had her first period right there in the wet grass, and Greasy turned to his partners and said, "Boys, I think we just found the gangbangers we've been looking for." He tossed the Superman lunchbox full of Chill at my ankle socks lipsticked in mud. I was like, "Yeah, partner. Where do I sign? Like now."

\section{Track 3}

I took the liberty of lashing out at everyone around me to call it a dress rehearsal for the Big Bad Wolf. The lawn was fenced in by Swiss army knives stuck blade-up in the ground. My nipples caught some soaked shade. Tiger was giving me the finger. Cindy Brady was bawling about the blood hurdling out of her thighs. Elton John fell in love with himself leaning up against another tenement building. Greaseball tossed us the goods, and Jethro was Bob Barker on The Price is Right. Right down to the stick baton microphone he kept in the back pocket of his shorts like a slingshot.

Payment negotiations for the barbiturates took the form of Catholic Church bingo under a big circus tent propped up near the neighborhood basketball courts. The mayor spoke publicly about how the City built them to keep niggers off the streets, and no one batted an eye or waited for a commercial break to take the sting out of it. The three other intellectuals waited in the car and read volumes of Encyclopedia Britannica while we and Greasemouth hid under the tent from the pouring.

Loosey said, "Let's get down to brass tacks."

"Nuts and bolts."

"The genuine article."

"Hard-hitting cable newsworthy." 
"Everything we've been looking for, and so much more."

We settled on trading our ratty tennis shoes for the lunchbox of pills, thinking we could pound the pavement making profit enough to buy four or five new pairs of Air Jordans. So we could style and profile all summer, and the ladies would love us from here to next August.

Cindy Brady was convinced she was bleeding out on the sawdust and begged us to call an ambulance-_Somebody call an ambulance!"— to come save her life. I flipped open my pay-asyou-like cellular phone and pushed the number 5 over and over until it was afternoon and night and the intellectuals were long gone in their minivan. Greasy said they were on a road trip to an academic conference they weren't invited to on the West Coast. I asked to see his credentials, and he pulled out his wallet and a laminated library card that had expired in May. It all looked legit, and he gathered up our shoes in his arms and got back into the passenger seat of the new model Hummer with the big Army tank engine that went VROOM VROOM loud enough to scare the pigeons off the gutters of the tenements.

All of us found pennies stuck to the bottom of our feet with cotton candy. We crunched and slid out of the tent while Tiger had his shoulders up around his ears. Cindy Brady told us she was going to be a supermodel someday just like Mariah Carey singing, "Honey." That's what she had become.

Jethro had a craving for Kentucky Fried Chicken with the familiar white face on the bucket. Clark Kent pressed his face up close and personal with my ribcage. We all heard the pills shake inside the lunchbox like a kid's tambourine from K-Mart. The cheap one with small tin cymbals. Rain against the softest parts of our necks pooling up and telling us to go on home for Shake N' Bake meals instead. Maybe, if we were lucky, the leftover seasoning bags would fit our feet and cover them in special spice coating with bite and pop. 
We already felt like the luckiest losers in the projects right then and there and had no idea how much a street-level swap meet could turn everything upside down in a blink of low-class media coverage.

\section{Track 4}

Fourteen old black women started singing hymns in the streets and raising their hands up to God. It was all of them out of breath and their mouths choking on rainwater. We took it as a sign from heaven and stepped our walking home up to double-time. Cindy Brady strutted stark naked down the sidewalk and whistled a Mary Poppins tune without a care in the world for her bare ass. All of the boys were pink-cheeked, though, because we knew better. There wasn't a single billboard near the highway advertising quiet rest stops or fast food joints. We made our own headlines out of dirty jokes we'd heard older boys holler in the school locker room.

"Newsflash: A quaint bed and breakfast couldn't take the heat of a honeymoon couple who lit their room on fire and Frenched all over the ashes."

"Newsflash: If you wonder why the cock crows first thing in the morning, you could do worse than to investigate the rooster's home life."

"Newsflash: Those dark-skinned brothers with big ol' biceps seem to be coming our way."

A bulky black Cadillac Escalade rolled down the street with Lamborghini doors tilted up like razorblades. The driver treated the holy women like test cones and weaved in and out of them popping wheelies on his big back tires. Some of the women pulled up their support hosiery and started crying to Jesus to save them from their sinful ways. Others danced to the music jumping out of the Escalade like marbles. 
We all had African-American skin and looked at the Caddy like a brother. When it got close to us, the driver rolled down the tinted-out windows and flashed a gap-toothed smirk. Elton John sitting in the passenger seat like a mix CD.

"You little brothers know where I can score some of the realness?"

We all shook our heads sarcastic like, "Nooooo."

The driver didn't bat a beautiful black eyelash before asking us what was in the lunchbox jammed all up in my armpit.

"Yo mama."

It was the only thing that came to mind. The driver's eyes lit up like he had waited all week for Sunday night.

"Now's your chance to be the hero I always knew you could be!" He had his hands cupped around the curves of his mouth to project the holler directly at the lunchbox's seams. Clark Kent looked around the Daily Planet's office like, "Not all the typewriters in the world could get us out of this jam."

\section{Track 5}

I looked in the Escalade's sideview mirror and saw my father in a bicycle helmet. He never believed wholeheartedly in the progress of the internal combustion engine. Plus, he was a punk and knew it. Like this one time, he ate caviar with a cereal spoon and was all like, "Hey, Mikey! He likes it!" to the butler dressed in hitman clothes. Cordial as you like, but goddamned if he didn't spit country out the side of his mouth like hot tobacco juice. And then he said, "Boy, you're a chocolate chip off the old block," like I was some kind of Keebler elf lighting the tree house factory on fire with his old shiny silver Zippo. We were always out of gas. 
50 Cent was getting pissy with a bad case of the nervous shakes. His whip shook under the weight of him, and Jethro was afraid of bad niggas he saw on BET, so he nudged me in the ribs like it wasn't raining bullets and whispered, "How 'bout we just give him the stuff and jet?" Tiger was clipping his fingernails with a pair of pruning sheers. Loosey was helping Cindy Brady find her womanhood. Both of them looked green in the gills.

50 whipped out an AK-47 and told us to hand over the SuperChill before anyone got murked. My father watched piss trickle down the legs of my shorts. Motherfucker laughed and laughed with carrot sticks stuck between his teeth.

"Your pussy ass ain't no son of mine."

I dropped the lunchbox in the piss puddle, and the shattering of the plastic freaked 50 out. His trigger popped off itchy, and lead flew low like nasty pigeon shit. Cindy Brady screeched something awful after a bullet winged her pink shoulder. The holy women tucked and rolled like the whole neighborhood was on fire / up in here / it's burnin' hot / it's on fire.

Not many people know that 50 Cent kills with a cackle in his throat and two quarters for earplugs. Loosey took one in the dome and was out like a bad game of checkers. Jethro couldn't get out of the way quick enough and got sprayed in the mullet till his brains turned into moths. Tiger didn't give a fuck and spit fingernails on the leather upholstery until the banana clip emptied in his belly and a peanut butter and jelly sandwich bled out. I didn't give a fuck either but didn't have any spit what with a dry fear mouth. I didn't have a penis.

Cindy Brady didn't have a penis, but blood was running down her arm like purple candle wax. The lunchbox was cracked open and bleeding its own pills out. I picked them up with my toes and put them back in their baggies one by one. The bullets were silent and dead in their bunk beds. Most of the holy women were asleep with Jesus. Cindy Brady stepped in small, loose 
piles of bile shit. 50 was listening to "I'm Supposed to Die Tonight" on the whip's stereo and stroking his taffy dick.

“Oh, good God! I've got to get this money and script right here!" He came on the last word and the black leather steering wheel.

I handed him the baggies of SuperChill and asked for his quarters as collateral damage.

"No sweat, lil' nigga." His eyeballs laced with sherm and semen juice.

He flipped the coins with his thumb and asked if I wanted to hold the AK for kicks. He knew I did by the way my head tilted like a classroom globe. I was previous to the parceling out of Yugoslavia, and the whole neighborhood could tell.

I held the gun like a submarine sandwich. One of the dead holy women was Curtis Mayfield. Another dead woman was Bishop T.D. Jakes with a Thanksgiving turkey stuffed in the breast pocket of his three-piece suit. Rain washed away all the fingerprints until the scene wasn't a crime.

I held the gun like a paramilitary commando blowing niggas heads overseas. Just like I had seen on the BBC World News program hosted by the cat with an accent and smooth wave hair. He pulled the whole thing off like a costume contest and telling the truth.

50 said, "Bitch, get in my car," and I was all, "Fuck that, nigga! It's almost summer vacation, and I'm tryna get a public pool pass for free ninety-nine. On the discount. Pay me like you owe me!" He had his big Timberland boots on and was puffing a blunt packed with crushedup SuperChill.

I could smell the dust smoke as he hit the clutch, hit the gear, hit the gas, and he was gone. Seven surviving holy women took to singing Marvin Gaye's “Mercy, Mercy Me (The Ecology)" like they had given up on the Good Book. 


\section{Track 6}

Tiger's blood especially mixed with the rain. Into a cloudy crimson water you could dip your finger into in the street before it drifted off into the gutter. I bent down and used my finger like a quill pen to write out Tiger's dead blood until the ambulances showed up with first-aid kits and condolence cards.

I wrote:

It's funny how we remember the moves of a Chinese Checker game when our fathers were miserable cheats with the marbles. Options of moving the marbles little by little in straight and crooked jumps. Remember that shit? My father used to punish me for losing games against him. Trixie ran away from home the day she learned to walk and never came back. No one went out to search for her, secure a perimeter, or phone in an AMBER alert. My mother said, "The little bitch was no good at family game night. I suppose she'll have to learn how to make her own moves from now on." Back to the Future starring Michael J. Foxx was banned from our home for dirty words. Trixie with purple underwear around her ankles when she walked out. I had diarrhea almost constantly from the stress of being an up and coming paperboy. The leftover newsprint scattered on my bedroom floor like the bottom of a birdcage. I used to sing, then, in the boys choir. When it was easier to buy into the sainthood low and sell high, later, when the time was right to flush everything to Satan. The first time my father hit me was never. He was born without arms and legs and never hugged me to him and said, "Son, this is a good thing for

you. " I did anything he asked until his face shown with a recognition I hadn't seen since the day I was born. My mother threw herself off a bridge before delivering me. My mother grew up with a metric ruler tucked inside the shoulder of her cardigan sweater. Once, my mother called Hillary Clinton a dyke for staying with the President after his indiscretion. My father never said 
the word "nigger" out loud, but he wrote it all over the walls of his den with black permanent marker. When he was angry, he went to his den and slammed the door shut to write "nigger" all over the walls so no one could see. I hated to see my mother cry outside of church. She couldn't keep it together. She called her own mother on a cordless telephone once and asked for the secret family recipe. Took the whole thing down on index cards before the oven exploded and burnt our duplex to the ground. Our neighbors were pissed. We lived on nothing but ashes and lawn for five years before moving here on a subprime housing loan. We have pictures of pin-up women all over the living room. Playboy magazines all over the living room. I knew Tiger, Loosey, and Jethro for about a week. My father didn't like me playing with black boys, but my mother told him it was better than faggots. At least, she said, black boys didn't know any better. I can't swim without bleeding. I can't write any letter of the alphabet by hand. Here comes Tiger's dumpy mother with a shotgun and heavy eyes. Here comes Jethro's mother in a Ku Klux Klan outfit. Here comes Loosey's mama with her ass out and big blue eyes. All three of them are playing recovering crackwhores in an upcoming community theater production. Tickets are two bucks, and all proceeds go to the memorial funds of the three boys laying here dead and beyond. Doors open at 7:30 p.m. Curtain's at 8:00. For more information contact the box office. I can't make it myself because I've got stuff to do that night, but you should definitely check out the misery at the end of Act II.

\section{Track 7}

I never told anyone about my dream to walk to the wax museum and back without taking a water break. Now they would never know. Miller High Life slept through the whole shootout and was sunburnt to a crisp. She thought she knew what was best but ended up wet and scalded. I hollered to her to go inside and slather herself with aloe vera ointment, but she was asleep behind 
a pair of shades like Marilyn Monroe on a shitty piece of lawn furniture. She was a sleeping beauty pageant and knew the answer to world peace. I didn't recognize the neighborhood for all the blood and couldn't shake the feeling that something brutal had just gone down.

\section{Track 8}

The monastery around the way was covered in graffiti from the street gang kids wearing training wheels. Jumped into being big shots one petty at a time. Rain didn't fall on the monastery roof of overlapping stop signs. Everywhere else it spat in the cul-de-sac without ceasing, but the holy temple of big thug gangsters stayed high and dry all the time. Four big statues of Ol' Dirty Bastard protected the four corners of the building. All the monks dressed in black suits and ties like Samuel L. Jackson in Pulp Fiction. With a paper religion. A dedication and duty to getting C.R.E.A.M. off that spiritual tip. They were deeply devout televangelist motherfuckers with Bluetooth cellular headsets molded into their ear canals for eternity. People respected their conglomerate. They traded trash bags and cheap light bulbs for all kinds of ghetto salvation.

I watched the monks sit outside their monastery, meditating Indian-style with wilted bags of McDonalds breakfast cradled in the open spaces of their laps. Oh man, they were on some transcendental shit off a Stevie Wonder album from the 70s. I sat in the middle of the road crosslegged and pushed my pointer fingers and thumbs together at my knees until the weak joints turned pink and sore. A commercial airline plane flew overhead, spelling out an advertisement for Breathe Right nasal strips in exhaust. I already had one on my nose and inhaled the soggy stink of the garbage bins where local rap acts slept and combed their hair.

Two monks had their eyes open, scouting the streets for new recruits into the fold of silent Brothers. One of the black cats spotted me spotting him and motioned for me to approach 
the holy ground. I worried I was missing Hollywood Squares through the heart of the afternoon but picked myself up and stepped to them. The road was a French tightrope, and I had to suck my stomach in to keep from falling one way or the other. A news team from white CNN documented my putting one bare foot in front of the other on the wire. My father was the cameraman because he needed the money. Bleach and right-wing rags weren't going to buy themselves off the shelf. I wandered into the housing market with traditional family values on my mind. All the tenements in the neighborhood were built out of wet sawdust. I had nothing good to say about the rain, so I put a toothpick in my cheek and sucked on it until my mouth went dry.

"So you think you have what it takes to learn the sacred Wu-Tang sword style?" The monk had a world map tattooed on his bald dome, but he spoke with authority and not like the scribes at the Welfare Office.

"I don't follow." In that I didn't understand and fashioned myself an MTV generation iconoclast.

“Until you know justice, you won't know peace.” He went back to closing his eyes for a doze maybe.

If Tiger had any breath left in him, he would've called the monk one smooth operator. If Jethro had his wits about him, he would've wanted to take a trip down Memory Lane to the candy shop for sticky sweet that could melt in our mouths but not in our hands. The monk had Master Splinter embroidered on the breast of his karategi, and I was like, "Whatchu know about the secret of the ooze?"

His eyes split open while the other monks kept to zoning out and shot back, "I know it's destroying a square acre of Amazon rainforest an hour. And you think those 'captains of 
industry,' 'job creator' motherfuckers give a shit?” He was heated from the heart chakra. "And now what are we supposed to do? Drink grape-flavored Vitamin Water by the case and pray for some kind of environmental role reversal where we're the MCs and Mother Nature is the DJ?" White frothspit stuck to the corner of his brown lips and black goatee pasted on with high-performance glue.

"So I ask you again, little brother, do you desire to know the path to the True Path?"

It was a question from Where in the World is Carmen Sandiego?, and I had forgotten my grade school geography bee cheat sheet answers.

"I guess I don't have anything left to lose."

It was an ontological declaration cloaked in the lyrics of an R.E.M. song. The neighborhood had collapsed behind me while I spoke to the monk in pieces. I looked over my shoulder, and it was the movie set to Boyz N Hood II. I looked between my legs and saw a collectible G.I. Joe figurine and the cable news coverage of Operation Desert Storm. The block was Little Vietnam without God's great mercy.

Master Splinter was up on his feet, tapping his Brothers gently on their shoulders to shake them from their state. All of them had good hair and clean white teeth with a Crest twinkle. They sized me up from the way I wore my shorts loose off the hip and the flip of my hair. I had seen Rebel Without a Cause three times at the old theater and knew how to swing my chin around like nothing even mattered at all. They nodded in recognition of my learned swagger and asked how far I'd gotten in the public school system.

I said, "I am proficient in making the numbers jump and more than proficient in making the letters do their own things." 
One of the older monks in the back row smiled under his heavy nose and said, "You'll need all the words you can get."

Master Splinter was holding a paperback copy of the Holy Quran. Instead, it was a Chinese takeout menu. The Silent Brothers loved to jack Asiatic shit and pawn it off as ghetto fabulous. Nothing got them grimier.

I got wrapped in my own karategi with "Duchamp" embroidered on the breast. My shoulders warmed to the fabric under the rain. We went inside the monastery right as a band of drive-by shooters blazed down the street blasting at birdhouses. The stink of burning rubber mixed with fried rice and vegetables.

\section{Track 9}

"A bird in the hand is worth a kilo in the bush."

And Master Splinter pulled out a Pizza Hut box filled with cut cocaine. All the other monks bowed their heads to it and said silent prayers to John Gotti or Tony Montana. Each of them had their favorite patron saints of snow. Outside, it was a reverent damp.

A praying mantis had taken up in between the toes of my right foot, and I called him Blockbuster Video. Inside the monastery was a reverent damp and the dusk of spring. It started with a welcome foyer covered in autographed Elvis Presley headshots. UV lights overhead for a meticulous visibility. The floor covered in ski ball sand for protracted footing. Another one bit the dust.

"We're the pacifist pushermen," Splinter boasted and popped the collar of his karategi like a lowdown playa. 
"My poppa was a playa," I said and regretted it almost immediately. None of the monks had East Coast allegiances, except for a small-time hustler who had run numbers for Mobb Deep in the nasty 90 s.

"People never know you until they know you in the way that there's no going back." Splinter had the longest fingernails this side of Madison, Wisconsin and the bravado to match. A-cup bras hung from the ceiling of the shrine room. Some slow moving dudes in the corner were snorting lines of table salt to judge their own weight. Master Splinter said something about his Venezuelan cousin having a come up in the Cactus League.

"Brother can handle the curve."

\section{Track 10}

They were about to initiate first rites on my way to slangin' dope when a bunch of white boys in canvas shoes busted into the shrine room like it was a Nickelodeon game show prize. The monks whipped out slick swords but knew they were no match for the bazookas the white boys held as props on their shoulders. It went off like a Stephen King card trick.

"We're the Lunatics, no doubt." The leader of the white boys looked too much like Jared Leto not to say something misunderstood. The whole gang dressed in phony police officer uniforms like their fathers owned the place and they knew it.

Master Splinter scarfed a 6-piece chicken McNugget. The other monks did a blade juggle, then fell on their swords rather than duke it out with too much firepower for any chill brother to handle. A requiem played on an organ without anyone seated at the bench.

All the drama and music reminded me of cough medicine and crushed ice from a gas station soda fountain. 
I saw the monastery roof open up and the dark sky bust at the seams. Angels from all over the Continent flew up and down Jacob's ladder to throw the fallen monks over their knees and give them a Fatherly spanking. Bach cantatas over the loud speaker in the shrine room propped digital up over analog. Some women cloistered in the ladies room conservatively dressed. Most definitely not shaking their asses to the harpsichord songs. Most definitely not mocking the dead monk corpses shish-kabobbed like the Fourth of July.

The angels focused on making cogent remarks regarding the sanctity of life and the dangers of false pursuits. All of them wore Crip blue and Oakland Raiders pullover Starter jackets. The way teardrop tattoos never look exactly like the real black thing.

\section{Track 11}

I sat in the middle of a large lecture hall and waited for wisdom to show up on schedule. Everything felt like Oklahoma State University, but there were no young cowboys in sight. A pagan night nurse walked through the double doors and asked to see my student I.D. card.

"I don't go to school here and have never heard of T. Boone Pickens doing anything good for anyone."

She slapped me across my black mouth.

Each of her legs were peg legs covered in $E R$ scrubs. She snacked on Cool Ranch Doritos. My newest mixtape played out her iPod earbuds. My dick got hard hearing the muffled beats drip down her neck.

She slapped me across my black mouth.

"You got some kind of nerve trespassing on this campus, field hand." Her mouth was Tyra Banks. I wore my favorite t-shirt with the conservatively dressed supermodel silkscreened 
across the chest and belly fabric. In the image, she held the title of a familiar book above her bikini line.

"I don't know the first thing about saddlebags."

She slapped me across my black mouth.

"Sit still and stick out your dominant arm."

Her voice felt like a supermodel taking in the sun. The lecture hall didn't have a roof and was half-full of rainwater. I sat in the floating movie theater seat and stuck out my right arm on the armrest. This was no time to be a liar.

Her name badge read "Wanda, and she unpackaged a needle kit and roped off my bicep with a rubber tube. Everything about her technique felt professional. She stuck the needle in the vein above my elbow, soft and flush, and I disappeared.

\section{Track 12}

It was a vomit of my own design.

It was a color-coded miracle of modern medicine.

It was a crook fast asleep in the back of a bus.

It was a telemarketer trying to make a buck.

It was, "You should've known better."

\section{Track 13}

Jethro had loaned me his VHS copies of America's Most Wanted, and I watched them critically and took notes. After school let out, I would run home and practice sketching identifiable mugshots. All the criminals I made up from imagination and drew by hand. The charcoal pencils were a constructive Christmas present from my foster parents.

Sheet after sheet of black faces covered in tears. 
Tiger had a hunch that we were going nowhere fast and picked up some night classes at the local community college. Trixie took to piercing strangers' ears without them asking for it then mailing billing statements to their home addresses. Jethro got caught masturbating in a Gap dressing room and sentenced to community service. Donna Summer washed her hands clean of us and went to sell shoeshines at The Hot Spot night club. I took out a sensible small business loan and opened that bed and breakfast I had always talked about opening when the time was right. I called the operation Rise and Shine and hired former power forward Karl "The Mailman" Malone as the maitre d'. He carried the business on his shoulders and was known to take his breaks on the building's roof and count out push-ups until his chest and abdominals ached and burned.

\section{Track 14}

In walked a producer for a Def Comedy Jam stand-up performer who needed the Rise and Shine's grand room to film a straight-to-DVD event. My necktie felt too tight. Too tight to breathe comfortably, and I was intimidated by the producer's sharp haircut and slow walk. He was a silver fox and the devil's advocate.

“Make me an offer I can't refuse," I said.

The producer pulled out a bankroll of hundred-dollar bills and said, "Let my guy perform here or I'll smoke you like a Virginia Slim cigarette." His taste was impeccable, and I buckled.

"Take the grand room and the whole establishment for all I care."

I ordered room service to the management office and watched an important woman bring me an empty Styrofoam box. Her demeanor wore me down, and I sold her Rise and Shine for pennies on the dollar, instead. I asked her to marry me, and she declined for a better offer. She knew the silver fox by his first name and made his stand-up comedian squeeze her fresh orange 
juice every morning. I admired how she was superior to me in every possible way. How she didn't even rub it in my face that she had graduated magna cum laude from an Ivy League University while I was undergoing a penis enlargement procedure. In the time it took me to recover, I really could've gone places.

She called herself Gloria Estefan, Princess of Percussion, and I kissed the toes of her ballerina flats to let her know I'd be there anytime, anywhere. She farted out the bottom of her pencil skirt, and I was that fool for her.

\section{Track 15}

Miller High Life told me a knock-knock joke that's punch line was "a skinny little white boy on the run," and I took off like Joltin' Joe DiMaggio. I was down and out with three or four members of the Wu-Tang Clan on my tail. Scratch that, the IRS was asking me about how I had come into so much money after the fall of the Empire State Building. Nah, the National Education Association wanted to know how I had passed their standardized test regimen without penciling in a single letter C. I played my number 2 pencils close to the vest. I watched my back carefully and kept an eye out for teaching industry moles.

Queen B taught a mean sixth period World History and had the calloused elbows to prove it. City High was dry as ice, and our skin cracked into pieces while we waited for the final bell to ring. It was fourteen students to a teacher, enough to take the classroom over if we disagreed with the curriculum or all needed to use the lavatory pass at the same time. At least once a class period, three students choked to death on their bubblegum and slumped in their desks. Queen B would think it over, read the room, and keep lecturing ad nauseam on the incredible family wealth of Osama Bin Laden. 
"What I want you to get from this lesson, students, is that extremism is a product of Gross Domestic Product, and while we can't predict where and when the next act of terrorism will undoubtedly occur, we can track the sales of manufactured goods like, say, cheap Little Caesars Pizza, and see where that takes us."

Punks were firing spitballs out of soda straws to see where the ammo would end up. One of the perps was named Gary Cooper, and Queen B jerked him up by the earlobe and dragged him to the front of the classroom for some spaghetti Western justice. The blackboard was a big, black board. The rest of us thought, "Damn, Queen B is one righteous diva." She had the curves of an Aretha Franklin in her prime.

"Now take this nightstick," she said, "and get to patrolling." She handed Gary a stub of chalk, and he felt inclined to write, "We, the educated elite, will not diminish ourselves with such limited firepower," over and over until the chalk wore down to nothing and his fingernails screeched across the surface of the blackboard.

The sound jolted us all out of our daydreams of teenaged payback. If we had it our way, they'd never even see it coming. We'd organize into small, expertly organized and practically unidentifiable factions, and rule by discretionary force. That would be the way of things when we refused to pay sales tax on our school supplies and six-packs of soda pop. A true "Don't tread on me" moment. Queen B looked crushed.

I sat in a rocking chair and watched her rifle through the top drawer of her desk for important tenure documents. Like, could she get out of this if she really wanted to, and rededicate her life to the Cause? Gary Cooper was working on a story of how Queen B had touched him inappropriately behind the Driver's Ed car after school one day. All of her desk 
drawers were empty except for the bottom one filled with confetti. Her eyes had seen the Glory of the Lord.

\section{Track 16}

I learned to use a Nine from a woman with a pool cue neck. She said, "The first hit is always the hardest," and, "It gets easier when the blood starts to lose its distinct smell." Her name was Otis Redding with a broken heart. She was a kleptomaniac with sweaty palms. There was no love lost in the fifteen years between us. She once had a thing for the Carter administration. It always rained when she spoke.

We met a week after I was born, after I first knew myself intimately. She invited me over to her cold-water flat, and we ate corn on the cob and I read her back copies of the Chicago Tribune. She loved the sections where the murderers got their fill. Had me read her the obituaries over and over.

Neither of us held valid driver's licenses. We weren't going anywhere.

Monday morning crept around like it was light on rent. Otis pulled on her housedress, and we drove to the Hill. On our way, police officers sat in their cruisers giving each vacant handjobs. With their speed guns pointed directly at their partners' eyelids closing rapidly. Once in a while opening for a Hardee's billboard or semi-truck driver. Windshield wipers never stopping to think about what they'd done.

The Hill was a big dirt mound named after the Mayor's mons pubis. If you sat square at the highest point of the peak, birds of different species could see the top of your head and distinguish it from all the others. Teenagers shot hard drugs in the branches of state-protected trees. Almost none of them considered protection. 


\section{Track 17}

The plan was to rob one old woman at a time at gunpoint until Otis and I could both afford admission to graduate programs in our fields. We estimated a generation would have to die with grandchildren for us to have hopes at the Ivy League. Even with our most respectable extracurricular activities and fine letters of recommendation from the managers at the campus Burger King. The economics of it just didn't add up.

We scrapped the plan, and Otis taught me how to French kiss.

She didn't teach me that. She taught me how to knot a necktie on my own without the help of the rearview mirror.

"We've stolen this car for good," she said, "but you can't count on charity forever."

We ate with our hands. We got to know each other very well. She had hands that were the end of the line. We hung on each other's every word. She taught me how to hold her tongue between two fingers. Things catapulted towards harassment.

\section{Track 18}

The plan was to sell an excessive lifestyle to the teenagers who panhandled on the Hill. Our marketing materials would be the glossy photos of handsome celebrities getting their groove on. We would paste the images to thick cardboard backing and hang them from tree branches with chicken wire. Each celebrity would have a gang verifying his authenticity. For example, John Leguizamo would get vetted by the Latin Kings and proved Hard or Pussy. If Hard, we'd hang his photo from the Oak and wait for the teenagers to start handing us money from their socks. If Pussy, we'd have to take the tribal tongue-lashings we deserved. 


\section{Track 19}

Otis Redding chewed with her mouth open. Her cousin Sandra had taught her to belch with a relaxed jaw. She told me a story about brutally murdering a dairy farmer:

I knew him by the bleating of his goats. At night, when the oil from the lamp burnt out, or the Duracell batteries died and went to heaven, I would listen to the goats go back and forth, parallaxing their voices until I located the farmer's home in my mind. There became, after a matter of some days, no need for the human invention of sight. I replaced my eyes with those of the suffering goats.

He was a man of considerable height. I caught him with his bib overalls around his ankles. To piss without discomfort, his thighs had to be completely bare. He was cold and shivering in the dark. I got close enough behind him to smell the stray hairs across his neck. He wore a cologne called Old Spice that was popular with libertarian men at that time. Most women found it overpowering and distasteful.

His urine wasn't off-putting. In fact, I watched the arc of the stream rise and lower as he breathed and relaxed. My right arm hung slightly longer than my left. I wore a wristwatch and had the habit setting the time incorrectly on purpose to confuse myself. I liked not knowing where I was and relying on the kindness of strangers.

The farmer had a belly that stretched into tomorrow. It hung over the arc of his urine and obstructed it. I noted the breaks in sound against the toilet bowl. Romantic thoughts crossed my mind. All the things the farmer and I could to each other intimately in the moments between sounds against the toilet bowl. He kept a soap dish in case of emergency. The handle of the plunger was rolled down with a blue balloon. The balloon speckled in shit. 
He was the kind of man I could see myself settling down with. Or rather, I knew him from high school and he used to tease me ruthlessly about the pitch of my voice. He was the man standing right in front of me, and that was the end of it. My mistake coming when I took the time to crack each one of my knuckles like Mr. Tin gold.

The farmer heard and changed the direction of his urine significantly. I could tell by the look on his face that he supported a very specific Midwestern NBA basketball team. He wore it with consumer pride. I could tell by the look on his face that he had been pressured to support a very specific Ugandan child by an infamous Evangelical anti-poverty organization. On his own, of course, he never would have cared about a child or given a second though to sub-Saharan Africa.

He was a thin black man with stout fingers and reparation-fever. He stood almost exclusively on his tippy toes when he finished relieving himself. I cradled his soft penis in my hand until his urine puddled warm in my palm. I covered his mouth with my other hand so he couldn't scream out. He had the thin lips of a Scandinavian. I shouted at the top of my lungs for him. We shared a similar cultural and ethnic background at the end.

\section{Track 20}

I couldn't stop myself from saying the n-word with a British accent. Dignified. I couldn't help the strict sensation of guilt that drew the shaft of my penis firmly up into my pelvis. The air was sucked out of the Hill.

Otis Redding's ragtop convertible was good for almost nothing. I drank her in with the rain. Breathing out and trying to swallow coaxed me into choking. Otis couldn't stop herself from laughing nervously and wringing her hands. The moon was off the charts. 
I was reminded of my sitting meditation postures. One relieved specifically existential dread and chaos anxiety. My back took to being straight against the passenger car seat. The stereo speakers massaged the inner arches of my bare feet. Whitney Houston was doing an especially moving version of the Ugandan national anthem. Her voice was wearing night-vision goggles. Her voice flashed the flare of a whole night of airstrikes.

Otis jolted and swore she heard someone trying to end it all. I told her to put it all in the trunk of the convertible, and she slapped me across my black mouth.

"It ain't as easy as ABC."

We held hands for a moment, and I shifted in my seat. I wasn't comfortable with the weight of my body, the way things hung on my frame. We put it out of our minds and hopped out of the car. Scapegoats scattered across the grass of the Hill, and teenagers knew the force behind their own voices. They could accurately calculate how much oomph they would have to push out to scream over each other. Hypercapitalism hadn't touched them yet.

\section{Track 21}

I had my blinders on. I held a one-way ticket to love. My mother and father were very proud of me and kept proof of my achievements on their persons and on the mantle above the fireplace in their living room. One artifact was a photograph taken when I couldn't have been more than four or five years old. In the photo I am wearing mismatched socks and a sailor's cap. My fingers are disproportionate to the rest of my body. But hanging from one of them is a long, dead fish.

Only the fish has no eyes about it. Also, the fish has the build of an infant whale. It is, in fact, a whale itself caught on a family fishing trip in the North Pacific. My father graduating from a coastal university and my mother a roving earthworm gatherer and washer of fine clothes. 
My mother the kind of woman you could get along with despite her knowing that she was your intellectual and physical superior. Despite the fact that she was, when push came to shove, Marie Antoinette. That photo was framed next to a Little League participation medal and a bullet casing from a Civil War reenactment.

Otis kept a cache of family photos buried at the top of the Hill.

"It helps me do my work."

She grabbed a running teenager and shook him by the shoulders. Her hands aging and arthritic. I thought of being in my own home again, where I could think in peace. My bladder thumped inside and knew what it had to do. I grabbed Otis by the shoulders and slapped her black mouth. She was the illest of the ill and vomited down between her feet. All of her pistols wedged in the elastic waistband of her boxer shorts. I asked her nicely to hand them over.

"Hand them over, please." In reference to the heat.

"Mothafucka, you must be outta yo mind."

"You have no idea who you're talking to."

"I will whup yo black behind, so help me Gawd."

"Say that again, I double dare you."

"So help me Gawd."

"No, the first part. Say the first part again, I double dare you." I was feeling the heat of the rain.

"I will whup yo black behind ..."

I started to cry into my fists. Otis Redding had all her girlfriends high-fiving her now, giving her serious shine. I crumpled like a paper airplane. Everybody got on board. Milkweed against my knees. 
"Does the pussy white boy want his mommy?" They had French bread stuck in between their legs.

“My mommy’s dead."

They sympathized in their own ways.

"I never knew my mother, either."

"She left for Motown Records when I was very young."

"I knew my mama on a spiritual level."

"She took the trash out for my father but spat in his food."

"Nothing good came of her."

"I heard she reupholsters white people's couches for pocket change."

"I heard they sent her to reform school, and no one ever saw her again."

"My mama's the quarterback for the New York Jets."

I slapped Otis across her black mouth with a paperback book and watched her shatter into a million little pieces. Her whole vibe was a hoax. All the people on the Hill could see right through her. Only the guns remained.

One teenaged boy kept murdering himself. He claimed it was part of an intricate ritual that would assure him a divine peace, but we put an end to it.

A pair of teenaged girls began fashioning designer drugs after Madonna’s "Material Girl" music video. I considered mouthing one of the lick-and-stick tattoos from their handbags and pressing it firmly against my forearm till it took. The high coming from the skin sitting there and taking it. The pair of girls easily in their early 20 s and high as a fighter kite. A group of boys wanted to manage their chemical talent towards a buck or two for all of them, but there was nothin' doin'. No rest. 


\section{Track 22}

I took off my drenched t-shirt like a bubblegum pop music video. The Greek gods had collaborated in the layout of the muscles in my chest. I was hungry for a change. Or rather, I was hungry. I thought to eat and saw the Eifel Tower in the distance. It was lit up like a campaign commercial. Scratch that, I saw a Denny's restaurant in the distance serving 24-hour breakfast. It was late in the day. Gang members would be coming out soon in search of leftovers. I felt afraid and stuck in the mud.

Maybe two or three guns nestled in the grass. At least two guns, and I picked them up and tucked them safely in the elastic waistband of my boxer shorts. I had the heart to start walking.

I ended up hallucinating about the family fishing trip we took to the Hoover Dam before Mama and Papa called it quits. We went to the Grand Canyon and fished. Dawn triple dared me to lick the spine of a gecko we caught by the tail. Even though she knew how afraid I was of coldblooded creatures.

It was the first family trip we took with Ice Cube carrying our luggage like a manservant. He threatened to slit our throats for the disrespect, and we went to our sleeping bags each night of the hike-along knowing it was going to be our last. But Mama just had to bring her portable DVD player so she could watch Are We There Yet? over and over again with the sand-painted skies for a background. We couldn't blame her for being pregnant. All our hopes lived between her legs.

But from day one Ice wasn't having it. He asked me to tattoo his left shoulder blade with a sewing kit needle and a well of black India ink; when I refused he called me names behind my back like a stockbroker. 
"Little Nancy Reagan has her pigtails tied too tight," for example.

"I hope the storm blows over; we don't want wind redirected up Cowgirl Curtis's circus snatch.”

The second one was from Dennis Rodman pitching a makeshift tent, being as bad as he wanted to be. It rained to the top of the Canyon, the donkeys drowning alone at the bottom. Mama made casseroles over the campfire and told us ghost stories about losing her virginity to infamous Negro politicians. Papa grimaced and said, "Go on and tell 'em the one about Jesse Jackson.”

The story took a week of details and holding onto lost hopes. I thought of my mother as a sexy Negress and felt ashamed of it. The best parts of my mind had been corroded by cat calls and insufficient attention paid to Black History Month.

Ice Cube and Dennis Rodman kept chanting, “Go Jesse! Go Jesse! It's ya birthday! It's ya birthday!" until the baked beans burned, and we had nothing to munch on for the part of the story where Mama climaxed in rhyme and gusto behind a 1984 presidential podium chiseled out of Formica. It was Jackson's famous soapbox studded in pompous blood diamonds, the Reverend nothing without his showstopping. We all turned our sleeping bags into mosquito nets to keep the snitchbugs out. Nothing bit the way family business bit.

I snapped out of it and found myself crossing 8 Mile Road alone at night. It was the type of thing you might tell your children not to do if you wanted to see them give it the old college try. It was the type of thing you might tell your children not to do if you loved them, the way you might talk to them in a soothing voice on their birthdays - mentioning in passing that their vaginal deliveries were the choice of a very specific historical moment. Mentioning who knows 
what would've happened if the circumstances were different and a Dr. Strangelove thing had to go down. Mentioning a bomb dropping and the panic it causes during the plummet.

I didn't have time to speculate because a whole caravan of Black Belt dwellers were hollering at the top of their lungs out the back of a stereotypical getaway car. Exactly like it might show up on the 6 O'clock News without anyone thinking twice about double-checking the reference's character background. Their propensity for blind racism.

The black boys and girls had thin rubber bands for muscles. My own skin was the color of a stretched rubber band, and I knew how to talk to them because of it.

"Where you get that come-up from?" My voice cracked at the end, and I was toe up.

"Look at the little white boy tying his shoes in the storm."

"Smoke gets in your eyes, lil' nigga."

"The wheels on the bus go round and round, and all that's good."

“Get the cryptogram ready, lil' J. Edgar Hoover's got his posse rounded up for a brain teaser."

Loosey and Tiger flanked my shoulders, and I was seated high and mighty on Jethro like a throne. There was no traffic in the storm, tar puddles bubbling on the highway like Hot Pockets. I was the Big Cheese Dumplin'.

"You white boys lost at sea?" The driver of the hoopty had a gold-plated grill across his mouth with "Bank Roll" etched in Old English lettering. I smiled to show him my own grill that read, "Mad Thrifty." Game recognized game, and I spoke for my boys.

"We've heard about the ruckus of the project pills, and we're here to put our own ears to the street." 
Bank Roll's sidekick was a little Vanna White looking lady with an Afro blown out like Macy Gray. Her voice had the same charcoal rasp.

"Bank, baby, why don't we blast these fools and eat California rolls off their cold bellies?" She had the taste of a low-class street hustler and a bucktooth up front to prove it.

Jethro's back gave out, and I fell in a gutter. The hoopty bumped Ms. Lauryn Hill singing, "It All Falls Down," and Bank Roll nicknamed me Humpty Dumpty to himself. Eggshell white. I remembered the dairy farmer huffing glue out of a paper bag when his Medicaid flopped. Loosey and Tiger picked me up by the armpits and brushed the licorice stains off the back of my blue jeans. They were decked out in camouflage we'd lifted from a Salvation Army drop-off.

Some dirtyblonde-haired woman was washing her face in the sewage runoff and checking herself in the big bling rims of the lemon. I was like, "Hey, girl, whatchu know about the Backto-Africa movement?" and she was like, "Fuck that ol' bullshit, I'm tryna eat tonight." It seemed like the same type of urgency that'd kept her people deaf, dumb, and blind for damn near 400 years.

We looked to the highway shoulder and saw a dozen or so high school dropouts with bullet holes in their foreheads. Size and diameter what you'd expect.

"Your handiwork?" I asked Bank Roll.

He said something about the youths' minds being a terrible thing.

Greed got the best of me, and I caved in like a molar. Sweat like weak anesthesia.

“Give me all the SuperChill you've got." I pulled a wad of money from my front pocket. The good stuff. 
Bank Roll's eyes bugged out, and Macy Gray was all like, “I know this white boy ain't just accuse us of slangin' cuz we black!" Her ears popped from the altitude. Tiger pulled me aside.

"I know you ain't just accuse them of slangin' cuz they black." His eyes were pure melanin.

I needed a stiff drink but couldn't find my fake I.D. I turned my pockets inside out. Nothing but chump change and a City citation for vandalism. Defacing public property with my name over and over. My memory was back on the dresser in the bedroom next to my polyester Batman wallet with the black and yellow Velcro strip. I kept to storing my cash in my cheek like a hibernating rodent.

"Was it that obvious?" I asked.

"It was that obvious," Tiger said.

"Do you think they noticed?"

"They noticed before I even pulled you over here, son."

"Is there any going back?"

“There's a going back that involves you eating your words and licking your fingers after.”

I worried about possible repercussions over the way I spoke openly about working-poor African Americans. The worry stung and burned. I swallowed the worry down and calculated the camaraderie I had cultivated up to that point. Loosey and Jethro were calling each other the nword way out loud, waiting to see if anyone would step in and stop them. Call them on their bullshit. 
Bank Roll blew open the hoopty door and got to whoopin' their asses. Shit got ugly like a dance. Tiger and I watched from where we stood in a shallow ditch. Neither of the white boys stood much of a chance, what with Bank Roll's corrosive physique and sagging draws. Even his sneakers were untied and loving it.

Jethro covered his mouth to protect the 5 G's his parents had invested in modern orthodontics. Loosey punched himself over and over in the temples to do the big dude's dirty work for him. Macy Gray and her two flunkies in the back seat commenced to stuffing their faces with Orville Redenbacher popcorn and throwing ghost punches. The car windows rolled up to give the whole throw down a pressure cooker vibe.

Shit got realer than an interlude.

And sooner or later our boys wound up strung out on exhaust fumes, their busted mouths around the hoopty's tailpipe. Bank Roll stood over their buck-naked bodies and wore their getups like gang colors. Tiger and I were looking around for something better to do. Detroit in the distance had a hiss to it. Bank Roll thumbed his nose and got back in the hoopty. He waved his black hand at me like, "Get yo little ass over here."

I was in military school and hustled over. He was breathing hot breath into the steering wheel. I felt the creeping suspicion that he was about to slow roll my toes with his Hot Wheels car. Instead, he R. Kelly'ed the ignition, and we listened to the engine hum while Tiger turned and took a leak over my shoulder like the St. Louis Gateway Arch. Macy Gray sang her way right out of a mousetrap Bank Roll had set on the hoopty's floorboards. Her stooges squatting in the backseat were noddin' hard off that SuperChill.

Bank Roll spoke like, 'You didn’t see nothin', so you don't say nothin'. My lips were covered in white chocolate. Stuck shut. 
No local celebrities were out playing in the rain. I must have looked too interested in Macy Gray's friends faded-out with their seatbelts loose. Bank Roll spotted the loose envy in my eyes.

"You really down for some of the Sleep Dope?" he asked.

I didn't know if I was allowed to answer. My eyebrows raised up for permission. I wiggled my ears like Snoopy to his Charlie Brown concern.

Bank Roll took my small black hand in his own.

"Speak, little brother."

"I want some of that stuff that puts your brain out to pasture. I want that lowdown doze." It was an assassin's creed or a duck hunt declaration.

It was an entry into a pixilated virtual reality.

The highway littered with corpses of the men sent from Washington D.C. to accept or reject the city's waving white flag. They didn't have the motors in them to make it out of Michigan. Too much backfire.

It was an austerity way to live and die.

When I pulled my small black hand away there was a Post-It note with the glue worn off barely stuck to my wrist. On the front it said, "Paul Wall lookin' nigga," with a seven-digit phone number scribbled at the bottom. Bank Roll looked at me like he wished he had a bulletproof vest he could pop the hoopty trunk and hand over like a samurai sword. Dude had a receding hairline like I'd never seen before. Eyes to match.

I shuttled the note to my back pocket and asked if Jethro and Loosey were dead. Bank Roll shook his head but said, “Those lil' crowbars will get you killed if you don't watch your mouth." 
His window rolled up by itself, and he was out.

\section{Track 23}

I found the pavement plastered with college admissions paperwork. My knees gulped handfuls of the places people had been. I didn't have a ballpoint pen. Jethro sat in the lotus position rubbing the balls of his feet with his thumbs. Tiger was drafted to a minor league ball club. I had ballpoint pens gushing out the neck of my t-shirt. Captain Kangaroo rode by on his white horse to save us. He called us all little niggas who would never be nothin' in this world until we learned better. His horse shit all over the paperwork and smeared it with gallop like it knew something we didn't.

I dropped out of school a week later and took a third-shift janitor gig on campus. My beat was the English faculty lounge and two floors of classrooms. One classroom was laid out like this:

Four corners and walls to the whole room with a ceiling hanging children's toy dolls. Strings around the dolls' necks, around their wrists and ankles keeping them to the ceiling for good. There was still a blackboard. One of the men I nightmared as a kid lived under the stock desk. The desk came with the room as a rock bottom deal. I asked him his name while I cleaned insects from the storm meshing on the window. The window facing west to the gang neighborhoods all the white people were so worried about. All the houses in the neighborhood painted Blood red with Bozo paint. Yards slicked up with hair gel. Wise old Capricorns sitting on their front porches reading fortunes out of Lipton tea leaves.

People meant to be on campus never left campus for any weather-permitting reason. If they needed $2 \%$ milk or a box of Cheerios, a manservant employed by the University would run and fetch it from a supermarket he knew by heart. If they needed Kentucky Fried Chicken, the 
manservants would put on their small swimming trunks and get on the good foot, their wooly skulls cooking in hot bacon grease. If it wasn't raining the people would talk about the manservants' mothers' strange ways of predicting wild weather. We called the manservants nicknames like "Noble Savages" and tipped them with handfuls of Sun-Maid raisins.

The school desks were covered in pine tar and peacock feathers. I know it because I saw. I plucked the feathers myself and plumed the desks by hand. Nancy Sinatra didn't help, just like she said she wouldn't. She sat on the window ledge with her feet hanging out over the razor wire fence. Smoking cigarettes one by one, and the black city devils weren't allowed in. Not even so she could check out the credentials on the manservants' résumés and watch them start planning their shoeshines, preparing their lips for the suction involved. The necessary way to bend from the lowest parts of their spines.

Penny Lane got her cake up and majored in pastry chef. On her first day the whole family followed her to the bus stop just in case she got uppity and never came back home. Her mama said, 'Sweetie, don't go thinkin' just because you're white everybody's gon' bend over at the back to get you ahead in this world."

Penny was like, "Yeah, yeah, mama. You sure know how to tell the whole truth." Her father was itching that top most curve of a man's ass crack. His face stuck in a strange pleasure. Little Pepperhead ran around his parents and big sister barefoot and skull full of Skittles candies.

“Pepperhead, calm yo wily ass down befo' I give you the beatin' of yo life."

"Boy, you better stop that foolishness and learn the proper way to behave in a democratic society." 
“Don't you want this family to get the high-class tax breaks it deserves before we ain't even white no mo'?"

“Little nigga always did watch too many Walt Disney cartoon movies comin' up. No wonder he storms around scared and red-faced, runnin' his mouth about the workers' right to organize."

“Don't you want to kiss your big sister before she goes on out into the life of the Enlightened mind?"

Things were temporal, and Penny Lane dumped a pound of Hershey's Kisses out of her backpack. The chocolate shined in the rain and scattered across the perspiring sidewalk. The corner where Penny was conceived, in love. A city bus pulled up and splashed the family in gutter water. Before they could board, it pulled away honking its horn, the bus driver all middle fingers and cackling dentures. His union hat didn't fit properly. Another city bus splashed by, soaking the family again in shit and confectioner's sugar. Baking soda stuck to the lampposts and federal mailbox.

Her first day of classes missed her because of the public transportation breakdown. She started living under the desk of a classroom at night when I scrubbed the tobacco juice from the walls. I polished the hanging dolls with Pine-Sol furniture restorative. Things got lemony fresh. Things took on their own ways of predicting massive ideological shifts. How scores of teenaged boys beat their little teenaged penises in their parents' closet shower stalls before running out to the streets and proving the color of their insides. All masculine and aggressive.

\section{Track 24}

I read the old man's diary after he died and went to heaven. It wasn't my place. Language was never my thing. I treated the penmanship like a crankshaft. Dude's prose was off the hook: 
Some date in the day of my life,

Dear small world of the room here where I am, What up? It's been several hours since I last wrote, and things done changed. A gallon of water collected in a shoebox outside the building. Too bad it's where Mickey Mouse lived between movies. Now I know the true definition of pain. That feeling you feel when your best friend drowns in a foot of nature's fury, and you wish it was you. And you wished it upon him in the first place from jealousy.

I crept through the hallways in my underwear and felt like Morgan Freeman in The Shawshank Redmeption. Nothing changed in my voice from the steps. No one saw me but Jiminy Cricket wetting someone's whistle. The songs he sang reminded me of the early days, when a trust fund was the only way out.

\section{Track 25}

Jack LaLanne held the ceiling up with his fit arms. The floor carpeted in college admissions paperwork. Each of the four walls plastered in financial aid documents. A dead body studying, lying hunched in the corner. No, a classroom pet dead in the wooden shavings of its small cage. Nah, a stack of college admissions paperwork blasted in letterhead and thick Hellmann's mayonnaise. I cleaned the goop up with a special solvent I mixed from a chemistry set and brought from home. It did the job, and I kept it in a Pine-Sol bottle for safekeeping.

I was living under the classroom desk alone when the shooting came at night. A string of highly publicized murders took off like a commercial airliner delayed by weather. They waited and waited for the storm to stop, and when it wouldn't, they put each other to rest with clappers. Buried each other's bodies in flimsy Little Caesar's pizza boxes. Back behind the building where faculty members smoked cigarettes and formatted bibliographies for their forthcoming publications. It felt filthy and wrong to stare. 
Mostly, the windows fogged from the water cycle and got worse when things heated up on the streets. I couldn't see from the way my bandana slipped over my eyes like a yellow silk blindfold supporting our troops. I vowed not to stop cleaning until the high stakes military exchanges reached their natural end. Yes, I felt guilty about it. Yes, I felt a feminine pride that turned the guilt into a flower patch. No one could see me from behind the weeds.

\section{Track 26}

Bullets live to die with blood on them.

That's what the boys do, too. I watched them congregate around a Dairy Queen and play Stratego on the benches dipped in chocolate and flash-frozen. Anyone who didn't plot and plan became a mark, got called a stone cold pussy.

Through the binoculars, every one of them looked the same. Only the guns in the elastic waistbands of their boxer shorts told them apart. The very different ways they carried their bullets around in black metal clips. I trusted the stern looks they had learned from John Wayne movies, and the way their body odor fermented in the constant humidity. How they kept records spinning next to the soft serve lever, the flowing ice cream slowing the spinning down and clogging the turnstile up until everyone wanted their money back. It was a "cash rules everything around me" situation, and the management was a bunch of college-grad whiteboys who fudged on their time clock entries. No one was having it. They started dropping bombs.

\section{Track 27}

I had never seen a grown man before. The hair above his genitals frightened me, and I trusted it to the craftsmanship of Black Queen's Wig Salon. I trusted the artificial way he screamed and threw his hands up like he was flying home to Jesus. He flew home to Jesus when the boys filled his back with razorblades. When they stuffed a hand grenade down his throat he 
died and went to heaven. I picked his tennis shoes up off the classroom floor when they made it there from the heat of the explosion. Parts of his body made up the free weight repetitions at the Rec Center.

The sassy assistant manager got capped a week earlier for selling snow cones without a permit. Local drug lords spotted him sprinkling the competition's coke over the ice cubes and grinding them with cherry Robitussin. It was a cocktail of the neighborhood everyone could get behind. But the speakers in the men's bathroom were Mozart's Requiem, and there is no coming back from that when it's written in the score.

\section{Track 28}

I believed in time changes from one coast of the United Stated to the other. This was an example of that: When the University shut down due to lack of interest, I got a job at DQ cleaning up the blood. I considered the sponge and bleach the closest I'd ever get to investigative journalism. My father was hired to replace the dead manager on duty. He hired Henry Winkler as his right hand man. Or rather, he wrote to Ron Howard to ask if he'd film me scrubbing the blood up with my bare hands. Of course, Howard wrote back that he should slap my father across his Scandinavian lips just for living.

The blood smelled the same as the handle of the mop bucket. I felt nauseas and metallic and asked my father if I could take a labor break.

"Swallow a Pepto-Bismol shot and get back to scrubbin'."

"But my stomach knows the whereabouts of its dark defeat."

"Nigga, that Shakespeare shit makes you sound gay."

It was all from an $X$-Men cartoon where Wolverine takes up as a member of the working poor and speaks on their behalf. 
I felt a feminine itch and reached my rubber glove between my legs. The raised fingertips mattered.

“Boy, don’t you go scrathin' yo' pussy in my place of business."

"But, but, but ..."

"This is a franchise!"

"But, but, but ..."

“Take yo' black ass home right now, and tell yo' mama that it's no mashed potatoes and gravy fo' you fo' a month.”

I didn't have the heart to tell him that mother had died earlier that day when City Hall collapsed on her head. Or rather, I didn't have the heart to tell him my biological mother had never been conclusively confirmed on The Maury Povich Show. Or rather, I didn't have the heart to tell this strange man that I had stolen his son's costume as a dirty-handed way of getting a cleaning gig after the University let me go all persona non grata.

The man was a big black woman with an unflattering hairnet. She knew who he was, where he was going when she died, and what she was looking for in a man. He was the one who would watch Eyes on the Prize documentary reruns and cook low-sodium meals for heart health. Nothing ran in her family. Nobody, either, ran in her family.

"Life ain't a race," her grandmamma had said with her twisted old whitewoman mouth. Old bitch carried a rifle all the way to her Redeemer, just in case.

"Probably pistol-whipped Jesus hisself when He tried to offer her the Sinner's Kiss." Right now, someone up there is looking down on us and getting pistol-whipped by an arthritic old garbage bag with "White" printed on her driver's license. 
I took the woman at face value and followed her every command. There was nothing like huffing the bleach fumes and sucking on a Dilly Bar to come down. Drowsy off the chocolate crunch. All my coworkers were high school kids invested in the ideal of a world where race walked around invisible. More specifically, they ate curly fries with just about anyone and didn't give a damn about the Census Bureau or that weird feeling you get when the minute hand on a digital clock strikes a prime number.

They listened exclusively to the B-sides of De La Soul's Three Feet High and Rising. They told me every day on our labor break that I was unwell and should seek immediate medical care. They told me unequivocally to check "Multiracial" on the "Ethnicity" section of my next job application or college admission paperwork. I was like, "If you ignorant motherfuckers only knew."

Psych, I found those fools at the bottom of a Disney World theme park collectible cup. Trapped in lunch pail hell like that episode of The Twilight Zone featuring guest appearances by boy-genius Mark Zuckerberg and Sly Stallone as Rambo. Trying to get with the program and find a way out by any means necessary. I poked their pubescent bellies with my finger like the Pillsbury Doughboy. I ground barbiturates into their scalps and emulsified it with Mountain Dew. I tasted the rainbow on the Lucky Charms cereal box and felt the luck authentically.

\section{Track 29}

I went out on a limb of a poppy plant growing hydroponically on the roof of our apartment building. Its leaves were little deserts in the rain that signaled the hottest summer ever recorded was waiting in Golden, Colorado. Up in the Rocky Mountains, plotting its way of sweating us out of our own skin for three months. I thought of the summer pulling up like a 
Coors Light beer commercial. People all over the world joining hands and starting a love train. A love train, silver bullet for the lonely hope of spring growing in the poppy roots.

Hoodrats who had lost their jobs over nothing wouldn't stop throwing themselves off the roof while their babies watched them fall from the bassinet windows pointing west. Some of the hopeless women and thugged-out men sang songs while they floated to the sidewalk forty stories below. None of the local news correspondents showed up to cover the raining bodies because it wasn't breaking news. Rich folks who worked hard not to pay their taxes rubbed their hands together and their groins up against ATM machines thinking, "One less welfare queen to feed." One old man with false white teeth and deep pockets humped the machine too hard and came into the cash dispenser slit until it short-circuited and electrocuted him to death.

I watched him spasm with relief and fall face-first into the curb. Everyone else kept bumpin' and grindin' thinking, "One less Medicare mouth to feed, too."

One young black jezebel woman jumped like a ballerina off the rainspout part of the roof but didn't fall to the gravity song everyone else danced to. Instead, she hung in space all Neil Armstrong and Ride, Sally Ride, thinking the hell it would be to be lonely out in space.

I got on my hands and knees and shot marbles by myself around the cracked flowerpots scattered about like checkers. Hitting the pots earned a point, missing the pots earned two, and I flicked my thumbs constantly and watched my high score skyrocket. Sally Ride hung out over the drop, twisting her good hair and wondering where it all went sour. I watched her watching me and checked my wristwatch for the bewitching hour.

I still had 15 minutes or so.

"Who's got the drop on you?" I asked. 
I get curious, sore thumbs when it rains. Copper rust seeps into the joints below my thumbnails, and it ain't no joke. A mercury thermometer in my back pocket kept its eye on the barometric pressure.

"Ain't no thang like a chicken wang on a strang."

Her purse wasn't real gold leather. We were no such things on the roof.

"Where you from?"

All the cat eye marbles were going googly and making me paranoid.

"It ain't about where you from," Sally said, "it's where you at."

I saw her arms swoop in display supermodel fashion at the stale air beneath her.

“I always feel like somebody's watchin' me," I said, looking.

"You gotta jump for my love," she said, all bad faith and encouragement.

Like I was even looking for a long-term love thang.

We got to talking about the stock market crashing, planes crashing, the movie Wedding Crashers starring two big name funny men who laughed to keep from crying. My wristwatch beeped an Indiglo flare into the night that signaled it was time to Ziploc seal my marbles and save them for another rainy day. So as not to lose them over the balcony and risk the mental health of the streetwalkers all the way over the edge.

\section{Track 30}

Early next morning I woke up and ate a crumpled edition of the Sunday Chicago Tribune. Check that, I ate a sausage and egg McMuffin extra value meal with the wafer hash brown and washed it down with strong black coffee. I woke up in Paris like Jay-Z and Kanye West, not knowing anything about the concept of Platonic love. 


\section{Track 31}

It was the Age of Digital Reason and crippling doubt. I saw a TV special about coping strategies squeezed in between booty-shaking music videos on BET. I picked up the phone and dialed the toll-free 1-800 number listed at the bottom of the screen. The long-distance call of a lifetime. And all I got was a busy signal.

I fell asleep in the rain and dreamt for a week without opening my eyes. Rainwater pooled in the hollow space under my sternum where high-class gentlemen came to play golf and smoke Havana cigars. Their mothers took good care of their investments while the hotshot sons recharged their batteries and dabbed big blots of calamine lotion behind their ears. My body became a stress-free getaway

The week held the City like a restless baby. Dirty diapers hung from the full-grown crops, where the highways met to do their thing. Blushing buildings with their fancy lingerie and desires to be taken advantage of in front of everyone they respected. Two politicians with prosthetic spines shook hands on a Native American burial ground. Out-of-towners ate the news up like Cream of Wheat or blue corn tortilla chips. Chunks of salt stuck in manholes brought traffic to a standstill. No good men got out of bed to tie their work shoes.

I dreamt three prophetic dreams that spoke to the nature of gun violence.

Dream One: I am nude in front of a mathematics classroom. The classroom is a delayed firing squad. I piss down the inside of my leg. No one notices, so it keeps running with fear. A voice from the loudspeaker hanging over the firing squad detail demands I recite the Declaration of Independence start to finish.

I refuse. 
The voice puts on a set of brass knuckles and pounds the palm of its hand with the neutral metal. It blares music composed entirely of racial slurs. No one I know is in the firing squad. Several faces become recognizable as belonging to the cash register operators at the corner grocery store. Penelope Cruz packs a huge heater. Clyde "The Glide” Drexler grew his moustache back and rocks it to and fro like Charlie Chaplin.

Father Abraham had many sons and daughters.

I met them individually in the arms of a pagan goddess. Her face was covered in shit and buckshot. Her teeth stunk like fine quail guts.

The PA voice was a big, bad cheerleader in an oversized sweater. It had cheers for days. The trigger-happy faces gritted their teeth and waited for the chance to pop off. They held mugs in their free hands that said things like, "\#1 Dad." I heard the call of like one or two angels, but not a whole heavenly host. A fat old cherub sat behind the classroom desk grading papers and touching himself deliberately. Three or four Banana Republic part-timers waxed the moustaches that all the men in the firing squad wore with an unconvincing sense of national pride.

I thought about death as an unreleased mixtape by Grandmaster Flash and the Furious Five. Of course, it was recorded into a trashcan lid and used to smother out grease fires in the projects. It never blew up like Melle Mel thought it would. Record execs called the same numbers, the same hoods, and after weeks of dead ends considered the mixtape itself a cultural relic on par with some corny Indiana Jones grave robber shit.

Someone killed me with their gun while sipping casually out of their own favorite mug. I bled to death on the cobblestone street. The scene became the subject for a one-act play titled, "Good to the Last Drop," written, directed, and produced by a Karl Marx-looking motherfucker with dirt and hemp under his coffee-colored fingernails. 
Dream Two: None of the Clintons RSVP'd, and we were left without a keynote speaker for the Summit on Blacktop Guerilla Warfare. Local streetball legends came in baggy AND1 brand shorts and squeaky-clean high-top sneakers, but no one recognized them without sweatbands and designer basketballs under their tank tops like a bad "yo mama" joke. Security battened down the hatches, fearing a suicide bomber threat from the neighborhood militiamen known as the Holy Rollers. A brother named Big Time, the Rollers' high priest, walked into the banquet hall like a boss and demanded to speak to the event's primary organizer.

"I'm the HNIC," I said.

"Man, you look like Jerry Lee Lewis."

He had me there. Right down to the stiff back and wild fingers. Hair oil. Kamikaze shots lined across the keyboard when the Muse couldn't speak for fear of rocking the boat a little too hard. Siren songs wailing like blues.

"What can I do for you?" I asked.

"You can start," he said, "by calling off this event, telling everyone to go home and watch the L.A. Clippers game on cable, and kneeling to kiss the ring."

Everyone watching us was like, "Daaamn."

I sang the opening bars of Meat Loaf's “Two Out of Three Ain't Bad” like a bargaining chip, but Big Time still pulled his pistol and shot me through the knuckles until the banquet hall blurred, faded to black, and spun its reels empty.

Dream Three: Bart Starr had the bulk of a Marine soldier and none of the undisciplined sass. I approached him with a handful of imported spiceds, and he smiled a knowing smile. He was considering the deal in earnest. It was a battle of wits, like things coming down to the nittygritty in the final round of a Jeopardy-style game show. 
He was like, "Show me what you got, nigga."

I started listing the countries of the world alphabetically and by GDP. Increasing from the poorest mosquito-infested landmines to the global superpowers overflowing with waste. My mind took over the situation geographically. Bart Starr sat stunned and silent. His mind crawled around on all fours. He couldn't access his peripheral vision because the face guard on his Dallas Cowboys football helmet got in the way. His gray matter shimmered against the flat Astroturf. He asked to touch my jockstrap.

"Hell naw, man!" I yelled. "You better back the fuck up!"

Here was a stadium we both had come to know as the cradle of civilization. A clean map of an interplanetary divide. The way God and Adam's fingertips never really touch the way you want them to. Instead, a reality that mimics a large ocean liner leaving port or a chimpanzee mother pulling her teat out of the baby's waiting mouth. I needed an Altoids breath mint.

I went Chewbacca on Starr's ass, howling up into the raining moon. Constellations belittled themselves after manic power trips gone wrong. The small things that perforate us at the joints until we break into parts.

The great Martin Scorsese crumbled like a sandcastle behind the camera off set. His body took on a lump of sugar and ashes. The director's chair folded neatly and leaned itself against a studio wall. I saw the canvas seat the way PBS painter Bob Ross might see it out from under his 'fro. Happy possibilities with shadow and light. I unwrapped a Snickers bar.

Three little Girl Scouts played Pick Up Sticks in the alley outside the soundstage. The buffer zone between Hollywood and the strip malls packed with chain restaurants. Magic carpets kept the Scouts' knees from bleeding. Down to their wilted stockings and patent leather shoes. 
The leader wore her blonde hair back in a banana clip. Makeup blown out like a real-life grownup. She couldn't stop sobbing and wiping her nostrils with her forearm. I felt for her.

"Leave us alone, you no good wino," she cried.

I was maybe five yards away in a pair of long johns held up tight by suspenders. My stomach rumbled awful.

"I'm no wino," I said. "I'm the maintenance man ... er ... I mean, I'm the Key Grip on this motion picture. I hold the Boom Stick until they tell me to stop."

The little girls shrieked and leapt up to run away. They thought I was signifiying. I grabbed the leader by the forearm like, "Please don't go. I have questions only a child might be able to answer," like, "Is this really how the cookie crumbles?" like, “"Dust in the Wind' is my favorite love song, too."

She pulled an Uzi out from under her green skirt and said, "Mr. Wino, you need to keep your hands off the property."

I had hair like cottage cheese. Body odor something awful and off-putting. I asked her if she kissed her mother with that kind of foul mouth.

"My mother died pushing me up against the world."

Kids say the darnedest things.

She wiped her nostrils and found a smear of blood across her front teeth. I couldn't go on. She dropped her gun and ran the direction of her troop, splashing through puddles and scaring homeless folks out of their sleep. I walked the opposite direction feeling sorry for myself. My mother had never breastfed her children, and the missing proteins led to glitches in our cognitive development. When it was too late, She demanded to see conclusive research till she was blue in 
the face. Said she had done nothing but love us unconditionally, but Dan Marino and I knew better.

We were the quarterback and fullback, respectively, on our high school football team. People called us the "Freeway One-Two Punch," even though our mother forbade us from playing contact sports. She was afraid they caused glitches in cognitive development. I wondered how much worse it could actually get.

Mr. Quarterback pulled each one of his body hairs out of its follicle and placed them individually on microscope slides. Our bedroom was a bunk bed and paper boxes filled with contaminated microscope slides. Our DNA matched perfectly and chilled our parents' blood.

A next-door neighbor killed Dan Marino before had a chance to make it big. The guy slipped an anti-anxiety pill in our pregnant mother's lemonade and she miscarried both of us. Now the bastard convict lives behind bars upstate, toning his lean body with calisthenics between mandatory chapel bible study meetings. Each year, he writes Dan and me repentant birthday card messages we read as weak pleas for clemency.

Real talk, we want his ass to rot slowly on a closed-circuit television set we keep propped up on a box of slides.

\section{Track 32}

Keenan Ivory Wayans brought his big muscles across the street and tapped me on the shoulder. I was all ears. My ears took center stage.

"I'm looking for something to take the edge off," he said. "My friends at the downtown YMCA told me to walk until I saw a whiteboy in a monk habit with his head in the clouds. They told me he'd go by the name Buffalo Bill. You him?"

"I'm Bill," I said, calculating the odds. 
"You got the problem solver, Bill?"

"You got the cash?"

He pulled a wad of C-notes out of the front pocket of his camouflage paramilitary jacket. I had never seen anything cooler. The air around us was a soaked hotel mattress. I felt my eyelids start to droop. Things took on a dream note. He tapped me on the shoulder with his big bald head, and I bolted awake.

"So have we got a deal or what?" he asked. His eyes burned out with a desperation I hadn't seen since Dan Marino's favorite cartoon show got cancelled and we had to start entertaining ourselves with puppet shows in our shared minds.

"Yeah," I said. "We got a deal."

Mr. Wayans looked relieved and let out a longwinded fart. Wasn’t even embarrassed about it, and I didn't mind at all. Traffic was stalled in the streets because two high school kids were losing it to each other in the middle of an intersection.

Things used to slow down for love.

I took a bite of the Snickers bar and chewed nostalgically. Women of the night walked by punching numbers into solar-powered calculators. Moving decimal points. Talking nonsense about community college and dividends.

I pulled a baggy of SuperChill out of the crotch of my briefs. The plastic was warm with puberty and mug. It felt like an ounce of the finest synthetic afterparty you can find. R. Kelly was notoriously hooked on the stuff and couldn't keep his sorry ass out of the tabloids. Keenan Ivory Wayans started itching for a scratch and shaking his left leg.

We made the switch. 
He got to steppin'. I opened a cheap ironing board on the sidewalk and steam-pressed his bills one by one. Folded them at crisp creases. They only felt truly mine when they were sharp and bow-tied. 5-0 pulled up right on schedule. Two oinkers in blue outfits hopped out of an unmarked Chevy Impala and asked if I was looking for trouble.

"Nah," I said, "I'm looking for some starch.” The bills wilted over like dying sunflowers in the night rain.

“Book ‘im, Danno.”

Danno kicked the ironing board over and claimed his prize. I felt my habit ride up and the twang of metal around my wrists. Beefy pulled his taser out like a cattle prod and begged me to give him a reason. Even the corner deli was on the edge of its seat, hoping I'd make the wrong move.

“What about my Miranda rights?” I hollered.

"We don't do that shtick anymore," Danno laughed. "Now it's all about the pomp and circumstance."

He ground my cheek against the concrete. One of my molars popped loose. A night crawler looped around my ear. I felt a half-erection poke into my lower back. Danno got to breathing heavy. It was all a slow dance at the Senior Prom. The stars were out for the night we would remember for the rest of our lives.

\section{Track 33}

Kendra got it all wrong. She thought I was in it for the love thang.

"Mookey, tell me I'm the only one."

We were in each other's arms listening to the rain sizzle on the radiator under the open window. 
"Baby, you know you are."

I was lying on my fingers crossed behind my back. She didn't suspect a thing. A bottle of Centrum vitamins sweat on the nightstand. Marvin Gaye belted "Sexual Healing" in that voice. I felt arthritic.

“When we gon' get married and get out of this terrible place?" Kendra asked. "When we gon' be free to love like white folks?'

She wore her makeup crooked as a fashion trend. Bloody blush smeared across her eyelids, lipstick outlining the veins on her wide throat. My wrists ached.

"I don't know, baby," I said. "When the time feels right."

"But it feels right now," she whined. "What's wrong with now?"

She sounded like an aspiring self-help book author. I wiped the perspiration off her forehead with the back of my hand. With the other hand I rubbed the lump of her swollen belly. Inside, a little one was watching television with the volume way up. Kendra tore open a bag of Cheetos and poured them into the creases between our bodies touching. The smell of orange cheese became overwhelming, and for a minute the room spun freckled like a disco ball.

"You know I ain't had a good payin' job in damn near six months," I said. "How we supposed to up and move away when we don't have no money? Plus, all our family's here. How we gon' raise a child without his grandparents around?"

I was practically gasping for air. The wallpaper looked like a Kleenex box. I barely had any body fat left.

“But why don't you have a job, Mookey? It seems like every day I walk by a store with a 'Help Wanted' sign hung in the front window. You just have to apply yourself.' 
I got up out of bed and brushed the dandruff off my shoulders. Our bedroom mirror was out of its mind. The globe on my writing desk was off its axis. The Teenage Mutant Ninja Turtles collectible action figures were melting on the bookshelf. Our Lil' Popeye wasn't even born yet, and even he wanted out of here. The room was an unmarked Chevy Impala waiting to happen.

I walked casually to the window and went overboard.

The last thing I heard was channel surfing in Kendra's solid womb. Nah, I heard the wind rushing past me as I fell. Not so much the heat but the humidity. I was a grade school science fair project. My mass moving the subject of scholarly debate.

People living in the floors underneath us kept the overhead lights on while they made love. I could see inside their lives with my thick reading glasses. Two men held each other like newborns and brushed hair out of the other's eyes while they breathed into each other's open mouths. It was the tenderest thing I'd ever seen outside of a movie theater. Their hands were into each other, and it showed.

In other lower floors women threatened to leave their husbands. The husbands ate Stouffer's pizza bread fresh out of the toaster oven.

"Go ahead and do it," they said. "See what happens."

The women stuffed themselves and everything they owned into scuffed white suitcases. It was beyond them, even in these moments.

\section{Track 34}

I crept up behind myself and understood the risks. No way did I want to go out like this in the middle of the afternoon. In broad daylight with the rain breaking everything apart. Kleptomaniacs walking the street shameless with their hands in their pockets. My own mother 
swiping salt and pepper shakers from diners like it was no big thing. An oil tanker ran over a miniature dachshund and kept on driving. A hot dog stand vendor read the animal's eulogy off a take-out menu.

Bold colors were in season. Women revealing small parts of their breasts, the least interesting parts, to the men and women who would look. I tapped myself on the shoulder and fell. I answered myself and spoke. The smell of chamomile tea brewing in the back of a garbage truck. My right pocket was packing lead. I asked myself what was in it for me. Like, if I took it out, cut weight, would the fall last longer?

I was holding.

Two dozen plastic baggies of SuperChill chopped up and dyed with green food coloring. I licked my finger to check the direction of the wind. It was fast going up. The direction was true north. I licked my finger again, dried from the fall, and dipped it in the baggie like sugar candy. The sky bled a warm blanket of rain I knew on my face.

Radio antennas were still in working order. The sound of things would last into peoples' homes. I rubbed until my gums were dark green and bitter. It was the good shit Richard Brautigan had promised, straight from his grandfather's watermelon farm in the West Indies. My mouth bugged out. I lost my tongue. I pulled my tongue out of my mouth and let it fly up. The rain stopped until I told it to start up again. Things illuminated into a halo crowning my skull. The top of my head was African-American. It had the full history of a gang of monarchs. Beyond anything I had seen in silent documentary films. I waved my arms like crutches and felt their senseless limp. My stomach let itself breathe out for a change. 


\section{Track 35}

Code-X was the Doc with the most. We met at his office on Monday and talked shop. His shoes were clean black leathers imported from Germany. I trusted the way the arms of his eyeglasses pinched in at his husky sideburns. He sat his big belly in an easy chair next to a table lamp and packed a pipe full of Chronic. That Endo. Cali Bud.

"What's on your mind, Christian?" He came correct.

“I don't know where I'm going," I said. My teeth were on edge. I had the Jaws of Life. "I don’t know where I’ve been.” It was a melodrama.

He pushed his glasses up his nose with an Afro pick, then stuck the pick back in his 'fro. Cool as you like. I admired the uplifting photographs on his walls of white families on vacation. The children consistently smiling, sunburned, and holding silver dollars in the cups of their hands. Nothing was out of control.

“I see," X said and made a series of marks in his notebook. He sparked the weed and took it all in. His office windows looked out over Lake Michigan, and we watched white families operate sailboats for a half-hour before saying anything else.

"What's on your mind, Christian?" Code-X was blazed on some other level time travel shit and didn't remember asking already.

"Damn, Doc," I said. "I told you my thoughts are on the low-down and dirty."

His eyeballs rolled the dice. I spit shined my shoes and checked my teeth for lipstick stains in a compact mirror. X looked me up and down like a strip steak. He licked his dry lips with the fat of his tongue.

"You don’t appear all that bad," he said. "Like Donna Summer looking for some hot stuff baby this evenin'." 
"Well, looks can be deceiving to the Utmost."

The Doc leaned back in his chair and took the weight of it all in his head. His brain had gears like a gizmo machine poppin' out the side, and I knew better than to disturb him while he was calculating.

He took another hit of his pipe and coughed like a virgin maniac.

"How's the SuperChill treatin' you?" he choked.

I thought about the handful I had crushed up and folded into my scrambled eggs earlier that morning. It had taken the edge off till British Tea Time at a quarter of two. Then the shakes took up residency with the stern voices in my mind.

The voices were the same Doom asking me quiz questions on Darwin's The Origin of Species. I answered every question like, “A theory is just a theory is just a theory,” with my cheeks full of ice cubes to reduce the swelling.

“Christian?" Code-X was faded but on the clock. "I asked you how the low-dose of SuperChill is vibin' with your system." I thought of a stereo system shaking from the feet up. "Are you experiencing any negative side effects, or is the half-life taking you to another planet for the heck of it? Tell me something about the metabolic tolerance of your mind."

I took the bait and spat out the gory details.

"I wake up with my eyes full of pus and consider the worth of the day ..."

"I'm going to stop you right there," Doc said, all up in my business. A true professional. "What time are we talking about when we say 'wake up'?"

"I wake up with enough time to get to Denny's before they stop serving Grand Slam breakfast combos. I order coffee with cream and sugar. My ballpoint pens are lined up next to the napkin dispenser. I shake salt and pepper on the table for traction. The pen caps come off, 
and it's go time. I flip the promotional placemat over and go at the backside like prairie grass. I go at it with the vigor of a much younger celebrity. The paper gets told how it is and how it's gonna be."

Code-X scribbled in his notebook like a crackhead comin' down. His Afro all askew and his pit stains in full force. I checked his credentials on the walls, and the medical degrees were framed by a gangster lean. Malcolm Gladwell College of Professional Inquiry boasted a proud list of notable alumni. I kept going.

"I drink the coffee black and mild. The words take to the menu's back like a flight plan. Some short poems based on slave narratives, fiction after flash fiction, the memoir that would be a screenplay in the right pair of business slacks. My penhand goes and goes until the day-shift waiter, Clarence Major, brings my short stack and ham hock out on his shoulder. His tray has the weight of a man's world on it. The menu starts to say these things about the ways of the mad world out of me, like a stream of consciousness diary entry:

First and foremost, there are no trustworthy characters in the rap videos with bikini bottoms clapping and clapping. I knew a man once who held things back even where the Hoover Dam wasn't concerned. The man was named Conway Twitty with his white sideburns signifying authority. I write his songs longhand from a perched brilliance. Out the window the fighting niggers blowing each other's brains out. There with their heads wrapped in plastic grocery sacks and revolvers up their sleeves. It wasn't like this in Twitty's country western South, where colored men pushed in railroad ties with the soles of their feet. Grateful for the labor and weekly cottonmouth wage. He used to sit on the front porch, he said, sucking black licorice and staring into the sun. He said some bad mother in the family line named Big Daddy Kane came over on the Santa Maria with the rest of the Spanish Armada. His left leg gimped from unequal footing in 
the small lettuce town where he was raised. Big dreams of becoming an American rap star ahead of the game. Before the game was the game. 'Hood to himself, chains for long nights and days alone. Livin' OG style until the white men took it away from him with the barrel of a bigger gun. I eat the way I want to because he didn't shave his head and start lookin' for cult leader trouble. Kept his nose to the ground to sniff out a life molded into a clay sculpture imported from faraway Paris, France. With its indigo influences and subtle backstrokes. The black men outside have spilled each other's raspberry juice across the parking lot now."

Code-X was going at his beard like crazy, twisting the tips of hair into fine Jamaican dreadlocks. His chin against the imperial rule already, thirsty to see Babylon fall and break its neck.

"Tell me more," he said excitedly, "about the SuperChill milligram dosage."

He was poking me in the liver with a yardstick and jotting "something" in the leatherbound notebook. A cage full of purple hummingbirds sucked raspberry juice out of a translucent plastic flower. U2's Greatest Hits semisweet on an original compact disc player. I felt like a newborn baby getting into its first fistfight.

"I haven't taken a shit in two weeks," I said. "My stomach feels like a pair of new shoes. I got an email alert filled with black bile spam. Most of my thoughts are drawn with Crayola Crayons on brown paper bags. I no longer trust my long-distance telephone service provider. Both of my arms are throw rugs. I vomit and feel like an elected official."

"And how about the anticipatory anxiety we have come to know so well?" he asked. His beard was a college freshman trying out a new wardrobe.

"I don't give a fuck about anything anymore." 
He gave the beard satisfied strokes and took to carryin' on.

"Success, my boy, is the type of thing written about extensively in peer-reviewed scholarly journals. You, your guinea pig success, will be the rebirth of something like the whole field of therapeutic psychiatry. Your frozen brain will be the peak of what we can do when we clink test tubes together and drink to mental health.”

His eyeballs caught fire while he spoke, but there wasn't enough oxygen in the room to keep things going. I started to clam up. I sucked in my belly to minimize. Shifting to a smaller state of being and conserving natural resources at the same time.

“Tell me about your sex drive." It was a firm request that showed the doctor's hand too much.

"Sometimes I finger my girlfriend when her father isn't home," I said. "He follows the surviving Beatles and sorts through their junk mail.”

"Really?"

"No," I confessed. "I try to masturbate to filthy women loving on each other but can't get over the nasty smell."

Doc was getting steamed. His notebook hand fuming like a grade school science fair project.

"Rate your overall happiness on a scale of one to ten, where one is the lowest of the low, and ten is Nicolas Cage in Gone in 60 Seconds."

I felt improperly calibrated and asked him to rephrase the question using more culturally relevant references. He acquiesced.

"Imagine you were auditioning for American Idol," he propositioned. "Which song would you sing for the judges?" 
“"Heart of Glass' without even thinking about it," I said. "I would forget the lyrics halfway through but hum the chorus and get away with it."

Code-X looked ashamed to call himself my adopted father. But the customer is always right. Especially when it comes to "Emergency Contact" and "Family History" information. I stood up from my chair to embrace him but balked. I was out of motion, taking things into consideration while the walls were still covered in fascist propaganda. The Doc shook up a can of Pepsi and opened it into my eyes. The old fizzyface routine, like it hurt me. But instead the refreshment grounded me in space and time. I licked my lips like I had never seen him before. We agreed to stare at each other without speaking for two complete hours. It was his bright idea, taken out of a Psychology Today article snipped with scissors. I started to stare with good intentions.

Almost immediately it went to weird places not talked about in the pop shrink periodical.

First, he took off his medical jacket and revealed the military tattoo he had gotten with his mother when he returned home alive from Vietnam. The blue ink swirled in uncanny directions, taking on shapes known only by the top hieroglyphics experts in the world. Part swirl, part looping hexagon, the image moved counterclockwise under his skin while I took it in completely.

The harder I looked the more convinced I became of Doc's affiliation with a Masonic order established around the time Abraham Lincoln's political career was grand and old. The thing I was sure of was that there would be no getting out. Not with the depth of line and the keen hypnotic spell I was under.

He whispered chaotic subliminal messages to my subconscious: 
"Your mind is taking you to a place of great calm, say, any casino and conference center in the greater metropolitan area. Notice the soft neon lights and the click of poker chips stacking on top of themselves like Nabisco Nilla Wafers. That's good. Allow your eyelids to slowly sink shut. Imagine small black men hanging from your eyelashes, weighing them down until your vision blurs and fades to nothing. Walk into the black of your closed eyes. Settle yourself into the empty space of your mind. Loosen your professional shoes and corporate necktie. Roll your neck from left shoulder to right. Cut the sleeves off your dress shirt until your arm veins bulge and breathe. Unlatch your trouser belt and hold it by the buckle in your dominant hand. Snap the belt like a whip into the dark space. Imagine me in the dark space with nothing but my voice. I am talking to you with the soothing voice I have now. You think to put a hot kettle of water on for tea. There is no oven range in the darkness of your mind. You throw the Nilla Wafers out into nothing. You throw a book of matches afterwards, then two celebratory cigars. I am not wearing professional dress in the darkness. I am in a sleeveless shirt as well. I am wearing Adidas basketball shorts of an early design. See the wide gaps between my toes in the darkness? Think nothing of them. We have more important work to take care of.

"You ask for a Barry Manilow album to be playing in the background. I oblige you. I pull out an old milk bottle chock full of SuperChill. You recognize your name and address on the prescription label. You spell out your name one letter at a time:

C-H-R-I-S-T-I-A-N. Until you're satisfied.

"You smell your armpits for body odor out of habit. You stink of nerves. I produce a SuperChill pill from the uncapped bottle. I hold it between my finger and thumb. I place it on the soft part of my tongue. You open your own mouth and stick your tongue out into dry nothing. Your mouth takes on an old taste. You step towards me, and nothing keeps you up. We embrace 
into a formal dance position. I ask to lead. You insist. Barry Manilow has his hands on our shoulders while he sings.

"Our faces take on an oil painting. Nature doesn't exist, and neither of us remember the faces of our parents. Your father and mother never knew the smell of pork belly. Mouths watering off of it. Our tongues touch, and the transfer is made. You swallow a mouthful of gritty lavender. Your throat and stomach know each other. It's wrapped around its neck with a bloodstream. You ask me to prick your finger with my beard stubble. I oblige. Your finger is a beautiful mess. We hold it between us and laugh comfortably. It's like the time you told me about swimming in a countryside lake owned by one of your biological father's old gambling buddies. You struggled to keep your head above water, but David Hasselhoff went all Bay Watch into the choppy swells and saved you. It was a similar resuscitation. You entrusted that to me, and we sniffed the lavender blood from your finger.

"I ask you to rate your happiness on a scale from Anna Nicole Smith to Marilyn Monroe. You say you 'don't fuck wit' white women.' You entrust that to me, and we sit in lawn chairs for the duration of an effective dose. You feel off the charts. We consider the darkness nothing compared to our skin. It isn't such a confusing way to exist out here on the streets.”

\section{Track 36}

I woke up to Code-X's fingers snapping over and over like a poetry reading. I was holding a copy of Leaves of Grass. Nah, I was holding hands with Paul Laurence Dunbar. We both wore Halloween masks of each other's faces smiling and frowning, respectively. Doc was pleased with the progress and handed me a thin, yellow carbon copy of my bill. Nothing was on the house, even if you were vibin' with a nigga. I felt a privileged sweat break out across my ass. It was quickly absorbed into a pair of Dockers khaki pants and cooled away. 
I took to the streets in my Dunbar mask and saw motherfuckers wildin' out. Quincy met me outside a Subway sandwich shop, bouncing on the balls of his feet like Muhammad Ali. He told me RayRay had gotten breast implants to increase her chances of admission to a university that wasn't down with affirmative action. We decided to check her credentials for ourselves. I stooped down to tie my shoes and saw an assortment of Campbell's soup cans smashed paper thin and scattered like kitty litter. The whole neighborhood smelled like preservatives.

On our way to RayRay's, Quincy told me a ghost story about his stepfather selling cain to white folks:

"It was a dark and stormy night, a night just like tonight, when Steppops started fiendin' for a little extra paper in his pocket. He took to headin' out the front door and down the block when a Jetta full of sorority bitches roll up on him askin' about Adderall so they can stay up late studyin' for their cheerleadin' final exams.

Steppops is like, 'You cuties know where you are?'

“The white bitches were like, 'Ain't this the other side of the tracks and shit? Our GPS says so right here.'

“They showed him the screen with a 'You Are Here' arrowhead lit up in their college's colors. He figured he'd set them up with a different study aid in the form of all that good shit he had cut up into eight-balls in his sweatpants pocket.

“They was all like, 'We never tried snow before,' eyes bugged out at the sight of the baggies. Even though Steppops was thinkin', 'Y'all right and white, I know you've had a cold sniff of something after your yacht club lobster parties.' They didn't know for sure what to make of Steppop's marketing strategy, all, 'Adderall is coke with another hydrogen atom on the outer 
ring of the nucleus there.' But they were desperate for some pep and handed him a perfumed wad of C-notes with Gwen Stefani singin' some shit from their car stereo.

"The second they made the exchange, One Time ran up on 'em with their Berettas drawn and billy clubs swingin'. One of the dicks with meaty arms and a flattop haircut congratulated the phony cheerleaders on an undercover job well done, and they squealed with gross giddiness watchin' Steppops handcuffed and stowed in the trunk of the cop cruiser on account of some other dumb motherfuckers already shackled in the back seat."

Quincy flashed an old camera light bulb crack at the story's climax, and we both shrieked in horror.

RayRay's parents' house was a Victorian mansion with a lemonade stand next to the tire swing. Psych, it was a two-room shack with an outhouse fifty yards behind. We walked up to the front door that was a shower curtain. It kept out the rain and mud puddles falling through. We knocked on the curtain too hard and went right through, into the kitchen room with a potbelly stove burning in the corner. RayRay's mama was knitting an old-time college letterman's jack in a rocking chair. RayRay's papa was sharpening his small collection of butcher's knives. Both of them shot upright, startled when Quincy and I fell through from outside. Someone in the neighborhood owned a banjo and was proving it.

“Whatchu two crazy niggas doin' in this house?" RayRay's papa shouted.

Quincy got bold with his words and kept it simple.

"We're here to see RayRay."

“RayRay’s busy studyin’ for her SAT exams," her mama said from the corner. Needles squeaked against each other next to the scorching stove. 
"Plus, she don't need no gentleman callers no way." Her papa had a powder keg chest. "Especially from the likes of you two lil' fools."

But RayRay must have heard the commotion from the other room, because she came out holding two thick study guides across her chest. The pages soaked in pus and blood from where she had leaned over them reading. She held them slightly away from her body, breathing shallowly and with a grimace to prove what she could handle.

\section{Track 37}

People were screaming outside the movie theater downtown. Red, white, and blue lights spun in circles off the marquee. The light more yellow than it was white. Dumb and Dumber and Juice were playing a double feature. Time snuck up on everyone wearing its pillowcase ghost costume. I felt pathetically attracted to buxom women from the Golden Era of Film. My dick felt like a lead pipe in the welding.

Two-dozen bodies lay crumpled in the street outside the theater. Fat, white police officers wore their uniform caps and jotted notes in their small flip pads. Writing small enough to fit in the front pockets of their shirts and still be buttoned over. The bodies still dead while the officers took short notes on bullet hole placement, flesh temperature, eyewitness accounts. The whole scene reeked of Hot Pocket sandwiches. The cops held their short pens with greased fingers. Enough that the pens slipped and facts jumbled onto the pads as gibberish.

“What's goin' on here?” I asked out of nowhere.

"Move along, son. Let the professionals handle this."

"Looks like the goddamned beach at Normandy." 
"Now look here, you black son of a bitch. We lost a lot of good men in that battle, and I'll be damned if I stand here and let you compare these thugs killing each other over powder to true American heroes."

"So the murders are gang related?"

“Of course they're gang related! Just take a closer look at the so-called 'victims'!"

Officer Barney lifted the yellow police tape with his gray moustache to let me infiltrate the perimeter. I scanned the scene and saw young, black faces bloodshot and puffed swollen gray. None of the so-called victims had family members who fought in the Revolutionary War. Even worse, none of them possessed ancestry documents connecting them to the men and women who instituted the first chain of fast-food restaurants on American soil. Their blood pooled up in the street and attracted small swarms of big mosquitos, blood thirsty.

The officers swatted at the pests and draped the scene in off-brand netting. Still, some of the feistier mothers wriggled under the gaps to feed on the leftover bodies like long, needlenosed vultures.

“Guess how many of these young men attended Northwestern University?” Barney was chewing a stick of Trident and rocking back and forth on his heels. Giddy-eyed for my answer.

"How many?"

"All of them." He chomped on the gum like a bit.

"It's quite a loss, then, for the intellectual community."

"Nah," he spat. "It wasn't on account of their accredited degree programs. These boys served in various capacities as campus building maintenance workers, janitors, toilet paper stockers, presidential monument waxers, dormitory dining hall dishwashers, etc.”

He looked at me self-satisfied, like I was supposed to laugh. 
"So what you're saying," I pushed, "is they were the men that kept the university business moving, going, open, in the black?" I felt as righteous as Tupac Shakur staring from the van and asking 'Do I look guilty?' Barney let out a dismissive pipsqueak fart.

"Nah, it means they were shit stains cleaning up their own, and now they're in the red."

He poked me in the chest with his finger to back me up away from the evidence. C.S.I. extras dusted the bodies for fingerprints with stage makeup brushes. The manager of the theater sat inside the ticket taker booth reading a dog-eared copy of Entertainment Weekly. Things felt gelatinous in the rain.

I walked away until morning thought it proper to show itself. I slept on a park bench blanketed in headlines. The stories were soaked through and weak.

\section{Track 38}

Independence Day had struck an especially patriotic chord with the townspeople that year. Mothers threw poison tea parties. Fathers started burning down their homes as an act of civil disobedience against flat taxation without representation.

"If we can't have 'em, no one can." Dancing around the bowing flames spitting in the rain but living all the way to the property lines.

I sat and watched a white family throw rocks at their three-bedroom, one-and-a-half-bath, two-story A-frame with a front-room picture window and wrap-around porch. The stones had little pieces of paper tied to them with string. Each piece of paper contained a reason why its author would be hurling his or her support behind the Great Grand Old Party in upcoming midterm elections. The stocky sons had the best throwing arms and were pitching prospects for the regional minor league farm systems. Or, they were Olympic-bound javelin throwers who aimed for other athletes and judges on the track and field on purpose. The "accidents" garnering higher 
YouTube activity than winning a gold medal and posing for the cover of a Wheaties cereal box. The burning houses, stones, and democratic anger were just a warm-up for international clickrate glory.

Made all the worse by the relentless rain.

The middle class was holding on by a thread woven from the scalps of other middle-class single mothers living off their dead husband's government pensions. Scratch that, the thread was the flimsy roots keeping baby teeth in kids' mouths past their expiration date. Nah, it was a microphone cord without the microphone loud enough to voice or hear the voice of getting by clipping coupons.

\section{Track 39}

I followed a golden retriever home. Back to the house my parents lived in with their grocer's freezer. Where they ate the top tier of their wedding cake off each other's privates. Wax bride and groom and everything. Their house that I slept in with G.I. Joe was ashes like the rest of them. It had bought into the ideological shift from shopping center consumerism. The dog took a piss on the remaining patch of lawn, rear leg raised and everything. Common courtesy was to send out postcard notifications of the demolition to my folks' work friends, but there was no mailbox left or appropriate letterhead. And they had no friends or jobs to speak of.

They watched The Dick Van Dyke Show compulsively and modeled their own interior design scheme to the letter. My father's curved spine in a twin bed. My mother's short neck in a twin bed. I tripped over the ottoman and fell face first into the damp ash heap. My first impulse was to fan my arms and legs out into a snow angel. I fanned my arms and legs out and made a snow angel in the ashes. It was made more difficult with bare feet and an NBA licensed basketball jersey. 
My khaki shorts left a bad first impression. The golden retriever hit the road. A squad of Harlem Globetrotters recognized the symbolism of the angels and came over. They figureeighted television remote controls through their legs and shot them like free throws at the brick chimney sitting scorched but intact in the corner of the lot. Most of the players missed their shots to the left. The sore ones complained of a negative breeze.

"It's off-putting," they whined in Black English.

A high-ranking executive of a Fortune 500 company cancelled her season tickets after witnessing the debauchery. She screamed into her cellphone, "Nancy, you get my ticket broker on the horn right now, and tell her I don't want to see another circus shot until there is some significant improvement in the fundamentals of the game!" She was heated. All, "I will not be mocked!" and, "Who do these clowns think they are, Nancy? Allen Iverson refusing to answer questions at a press conference?” They needed some practice.

She shut her phone off with a thumb and jump-shot it at my parents' live chimney. Nothing but net. She strutted up and down the block. Business as usual.

A gang of feral cats wandered around treating the desecration like their own private litter boxes. The lead cat looked like Jackie Chan in that one movie. The rest of the pack looked like Chris Tucker in that same movie. C. Delores Tucker stayed out of white neighborhood politics. She was too busy baking Betty Crocker brownies and flipping through cable stations in a getaway suburb where people respected themselves enough to keep roofs over their heads.

I fell asleep in the middle of an angel.

I woke up in the University library reading Jean-Paul Sartre.

Nah, I woke up in the public library reading a copy of Sports Illustrated. 
Scratch that, the men in the public library bathroom were taking makeshift showers in the sink. The pink pump soap served as both shampoo and conditioner. The patrons left the facilities looking right. They had gotten laid off from their Firestone factory jobs at the height of their earning potential. Even though tt was forever tire season, and the Congolese rubber was coming in hot, begging to be Pirellis on 22" chrome. Begging to be Dub skin. Begging to be left on the streets in straight skid marks as proof of stopping too late.

See, the women needed the men to be the men they had read about in Little Women.

Psyche, they needed the men to be the characters they had seen in syndicated episodes of Dawson's Creek. No, the men were all star sprinters in slick Adidas track suits, runnin', dying' to live while they're just livin' to die.

I woke up in the middle of a major international drug transaction. Folks had taken to calling it "The Deal of the Century." Shit blowin' up cats' pagers. Blowin' up on Eastern European social media platforms. Slavic language speakers going apeshit.

The warehouse ceiling was tinted glass. Specifically, the glass leftover from a first baptism. The sun and rain hit the stained glass images of Christ and showed The Deal the Way to salvation. Two rival mob bosses played a game of chess on a card table.

I woke up under a sewing machine in the warehouse surrounded by the bosses' foot soldiers. They looked exactly like popular investigative journalism portrays them. Every Ukrainian man looked exactly like CNN. Portraits of outsourced masculinity keeping it real, down to the dry skin and crosshair eyes.

Imagine the faces of the bosses; they looked exactly like that. The foot soldiers hated their home country and their bastard fathers. The bosses did not know the rules to chess and were moving their respective armies arbitrarily. 
An elephant sat far away from the sewing machine but in the warehouse still. Its tusks were cut off and its stub tail wagged lazily in a heap of pure SuperChill. I knew it by the smell of elephant shit and its proximity to barbiturates. A craving came on and over me. Panic came with it in my extremities. My small penis shrunk up into my pelvis and piggybacked my perineum by being true north of it inside my body.

Raindrops tinkered with Jesus, crucified.

The mob bosses spoke to themselves in a Slavic language and pushed the chess pieces around with their cuticles. I needed the SuperChill inside me like a love thang. I dreamed of where I could stuff it. I asked myself what a mule would do in the same situation. A painting of Jimmy Fallon from The Tonight Show Starring Jimmy Fallon hung on the warehouse wall. Nah, it was Jimmy Carter. The painting was a large photograph of the Cold War ear. We were in a sweatshop that produced American-made blue jeans. The mob bosses spoke limited managerial English. I eyed the SuperChill very closely.

It fit very nicely in my tennis shoes. I tied the laces to each other and slung them over my shoulder. The handfuls of powder waves got bent down and scooped. Right into the insoles of the sneakers. Packed to the ankle and heel like baking flour. I walked barefoot by the elephant breathing painfully from its trunk. It bled from the stumps of its tusks and into the rest of the SuperChill batch. The mob bosses swiped the chessboard out of their way in unison and started Frenching. A defense mechanism in itself.

Sneaking out the warehouse door to the loading dock was the easiest part. I considered the left shoe as my head stash. The right shoe was my plaything. I felt powder money stuck to the bottom of my feet. The same as elephant blood. 


\section{Track 40}

Ocho and I decided to team up and take the city by storm. It was raining on our parade. It kept on during the times we sat alone and considered our futures.

"Let's become the Batman and Robin of slangin'," she said. "Let's run the game like Gotham City crooks.”

I admired her sense of misdirection. She was born without arms to point.

"Let's call this batch 'The Old Testament."”

"Let's call our guns 'The Wild Thangs.”

"Let's call our mothers or legal guardians on burner phones."

"Let's call the shots for a change."

"Let's play chess with old men till our fingers ache."

It was a sore subject. Ocho rubbed her sharp chin against her shoulders. Her miniskirt

rode up. I unrolled a map of the City across her Pocahontas bedspread. No, she was into Gilmore Girls. She liked the way white women talk fast and loose. No, her sheets reflected the simple patchwork style of a grandmother fed up with two generations of rat-race aesthetics. The map took on the lumps where the mattress warped around Ocho's body as she grew up.

We picked a neighborhood where the map plateaued. It would be our first-stop selling point for the Chill. Our teeth chattered together.

"Let's send our high school transcripts to Moody Bible Institute for pastoral ministry degrees."

"Let's substitute that out for a night of violent binge drinking, of taking the devil into our livers."

"Aaaahhh yeaaah." 
We cracked open a six-pack of Miller High Life and took to tipping them upside down. I thought to pour some suds on the pavement for the street soldiers who weren't with us anymore. Ocho took a beer bottle deep into her mouth. Her serpentine neck and the plight of her forehead. She was a dipping curveball off Los Angeles Dodgers legend, Sandy Koufax. Observing the Sabbath and shit.

I was knocked out on my feet like a heavyweight contender, running my mouthpiece something ridiculous. All hypermasculine crazed like, "You can't touch me, you're not man enough," to no one. And, "I'll eat your asshole alive, you bitch." And, "Anybody in here can't fuck with this." And even more so, "This the ultimate, man." And, "You're scared, coward. You're not man enough to fuck with me." And finally, "You can't last two minutes in my world, bitch.” So everyone not listening knew what I was up against.

Ocho knew better than to try to calm me down. Instead, she picked a Commodores album up with her teeth and let it slide, angled down onto the turntable. She popped the "Play" button in with her big toe. I rocked back and forth on my hands and relinquished control to dancing on the ceiling of our apartment.

\section{Track 41}

In the meantime, Mike Tyson mantras got me through the rough patches. I punched my fists into Ocho's ribcage while she bit her lower lip to deal with the pain. Even though I felt half of it in my own sides and didn't say anything. Stitches from oblique to oblique proving something deep in the way we hid our feelings.

The repetition of the jabs and hooks into my martyr-love took on the form of a guided structural meditation. 
I had visions of falling on my head. They were less real than other life forms floating in outer space. I recognized the aliens living in the noxious deserts, their own soft, unassuming heads.

Instead, there was another, truer vision of being placed inside a sensory deprivation chamber and convincing myself it was a Little Rascals-style clubhouse. I might have been seven years old. I might have known how to read and write small words. Two children's magazine subscriptions were delivered to the address of the clubhouse, but both were met by a "Do Not Disturb" sign lifted from a Holiday Inn Express hotel room door. Smeared unreadable with cinnamon roll frosting and raw egg yolks. Smeared with a shade of Revlon lipstick they don't even make anymore. Sports Illustrated for Kids and Highlights rolled into tight submarine sandwiches and bound with blue rubber bands.

The clubhouse itself was a hardboiled egg with no yolk. Its door was the front of a small iron safe. Complete with the numeral dial and pull lever. It weighed a ton and was kept in the storage room of a Toys R Us in Youngstown, Ohio. No, the store was located in Gary, Indiana, and was actually a Barnes and Noble bookseller. Nah, the clubhouse sat in Code-X's basement, built out of one-way mirror for easy observation. A logbook bound with cellophane didn't have a need for a pen. Doc wrote words with his eyes, and the paper in the book remembered.

Technology grew too quickly for its mother to keep buying it new shoes. Blisters and sores took over on the toes and heels. The insteps ached all over. Reflexology techniques were a foregone conclusion. Code- $\mathrm{X}$ declined to elaborate when asked to comment on my condition for the local newspaper's online "Watchdog" section.

Inside the clubhouse was nothing but me. I made other things out of the blank images on the glass walls. I spent what could arbitrarily be called "the days" sitting and counting the 
breaths I could complete before falling asleep during "the nights." Where the room was a pillow instead of a rocking chair.

I painted the space each morning with a hallucination. An amount of SuperChill dropped through a ration vent at the top of the chamber each hour to mitigate the panic associated with aloneness. A reminder that an objective Authority was looking out for my psychological wellbeing regardless of whether or not any lived experiences supported the claim.

Food came in Colgate toothpaste tubes. Water came in small papercupfuls to wash down the medicinal doses and quench any thirst that may have poked its head through. Music was forbidden. Conjugal visits from Janet Jackson were forbidden. I created her right nipple wrapped in a jagged silver sun in my mind as the start of something beautiful.

I took to writing on the floor of the clubhouse with my fingertips. Touching the soft footing with words. None of it was publishable or worthy of consideration in any way, but it kept me busy with literate activity, which I'd read reduces the risks of early onset dementia. I stuck Glade Plug-In air fresheners into a wall socket and smelled the room turn into lily of the valley. The scent lasted two whole weeks just like the TV commercials promised. After it dried out I took a shit near the discarded packaging to spite my own nostrils.

Nothing could be further from the truth.

I unplugged the valley and stuck my finger in the socket.

Well, I wrote a poem about The Sound of Music across the floor in my usual technique. I vultured a few breaths from the chamber.

I took to calisthenics. My muscles grew exponentially from a Pilates routine I choreographed off a recurring infomercial. Code-X encouraged this regiment by supplying extra 
doses of Chill only after I had broken out in a sweat. The experiment like a lab rat and cocaine stimulus thang. And a pitiful one at that.

Masturbation was strictly forbidden. I put my monk habit back on and felt the loose cloth touch me in unmentionable ways. Buster Douglass came to visit one morning, and I asked him how sales were going on the street.

"I don't understand the question." His innocent face shrunk.

“The Chill I lifted from the mob bosses," I specified. "How's it moving? How are sales? What's our bottom line?"

He kept up the confused act with his eyebrow cocked way off to one side.

"Have we met before?" he asked. He looked dainty and official. Peppermint sticks poking out of his sport coat pocket. The Daisy Dukes I had bought him on our first vacation to Baton Rouge together.

"No," I said, confident. "I've never seen you before in my life."

It was a brutal lie, but telling it brought a surge of excitement I had never felt before. Three's Company's Suzanne Somers stepped in to officiate. An old Irish man wrapped my fists in black boxing gloves. His wiry-haired assistant wiped my cheekbones with Vaseline. An overweight black man in a bowling shirt pushed a mouth guard through my lips. Someone rang a doorbell.

Buster beat the shit out of me. Until I was unconscious on the tarp. Until he was standing over me naked. Waking me up with a stream of one-liners and urine. He was singing a George Michael song I had never heard before, his nipples and chest hair exquisite with beads of sweat. I blanked on his name. My face swelled to twice its normal size. 
A conviction grew inside me to protest the legality of blood sports in all Northern states. The head trainer held a mirror in front of me so I could survey the damage. In the reflection was the image of a draft dodger. I saw Cassius Clay as Muhammad Ali very clearly. The takeaway was supposed to be valiance in the face of defeat. Instead, I wet my boxing trunks in fear. Cold piss ran down my thighs to the tarp mixing with Buster's other piss. He was a big black bastard.

"You big black bastard," he said, and spit his mouth guard down at my face. I caught it in my own teeth.

\section{Track 42}

Other fights were scheduled, but I ducked them like a choosey coward. I took up another trade. People came by the apartment for violin lessons, martial arts classes, potpourri design. It all worked out in fancy ways. I was instructed to take no thought for my life and instead rely on the intuition put into my mind by Almighty God.

I converted to the Nation of Islam with hardly any resistance. The Autobiography of Malcolm $X$ took its rightful place by the headboard in my bedroom. I began ballroom dancing while maintaining respectful space between myself and the body of my female partner. We baked together and gave up swine. We decided to slow life to a miniscule wince and settle down together. It was predicted in the stars. I saw them for myself in the ceiling of the clubhouse. SuperChill was dispensed enough for the two of us. We wanted for nothing. Building a family became natural conversation.

Courtney Love had kidney stones and a big head. We bonded over our shared beliefs in white supremacy. None of the smoke and mirrors stuff you see on family sitcoms like Step By Step. Her cooking was out of this world: nothing but casseroles, until I thought notions like 
"hunger" and "craving" were the stuff of Other, less civilized nations. Hers were the blonde features of an Ernest Hemingway.

I loved her more than horseracing — she forced me to give up gambling after I lost our clubhouse home in a freak Kentucky Derby hijinks. Full Monty, the frontrunner, was cut off in the last quarter-mile by a bullet through its neck and mane. All the other horses puked in agony. They had had enough of it. We all lost our shirts to numbskull bookies who had never graduated from high school. They had no academic training at all, but kept numbers stored in their minds for a rainy day. When it never stopped raining.

Of course, Courtney kept her anger on display like a coffee table book. Crammed in the chamber with the rest of our belongings. When she got belligerent, Code-X took her SuperChill away.

On the contrary, he upped the dosage to half her total body weight. Her blood took on a crystalline shimmer. She caught the attention of other men in the neighborhood. She got hers while the gettin' was good.

I got home late from the factory one night and asked for a dinner menu. Courtney was sitting at the kitchen table listening to Nirvana's Nevermind on a Walkman.

"Pork chops and applesauce," she said, blowing cigarette smoke out from between her teeth.

I was so incensed over her deliberate breach of our religious dietary restrictions, I didn't even notice the big, black cock stuck firmly in her asshole. It wasn't mine; I knew that for certain based on the respectful space between our bodies. The cock belonged to our neighbor and longtime friend, Dwight "Doc" Gooden. He kept thrusting into her while I fumed over who had 
come for dinner. She had an ounce of feminist agency in that she squeezed Doc perpetually with her rectum. She orgasmed almost without end. He sniffed and sneered like a bad habit.

Real talk, Dwight had been chemically castrated after a previous drug run-in with the law and was forced to perform a climax that wouldn't pass for genuine anywhere. He jerked his hips forward too quickly, lazily pulled himself out, and crumpled against Courtney's wide back like a bagpipe. I shook my wedding ring finger tattoo in his face while he wiped himself clean with one of Courtney's grandmother's crocheted dishrags. If she could've seen this black ace dabbing at his manhood with her handiwork, she'd have rolled over in her Yankee grave.

My diatribe was epic and bombastic. I didn't recognize international waters, political contingencies, or the etiquette of so-called "emotional intelligence." Instead, I gnawed on a slice of Oscar Mayer baloney and chastened Courtney with a far-out lecture on American Transcendentalism. Nothing was going to last, not even our capsulated love for each other. We were nothing but placebo pills in the belly of the beast. How could we even begin to listen to Elton John albums again, like we had when we'd first started dating, when our kisses were young and coated in thick sweat? I remembered her upper lip and the things she used to do with it.

She walked out the front door in the middle of a PowerPoint I had prepared on infidelity. Or, it was a second-hand presentation on the proper way to compile recipes for a community cookbook. Whether or not to ask for contributions from every woman in town, or only the ones you had tasted for yourself.

I sat in the cell like an ascetic. A heartbreaking amount of SuperChill dropped from a cumulous cloud. I took it as an incentive to remarry, to get back out there and force someone to leave me again. In the wake of Courtney and our argument, I forgot to take care of the simplest parts of myself. Things ached no Doc could cure. 


\section{Track 43}

They had me strung up at the wrists behind a Walgreen's pharmacy pick-up window. The ambiance cut in half. My toes dangled above a box of light bulbs. Perverts tickled my bare armpits with a feather boa. The same torturers threatened to pressure all my joints in the wrong directions. I didn't understand the orange-lit "Exit" sign over the half-counter on a hinge. There were a half dozen of them in lab coats and thick reading glasses.

"Who turned the air conditioner up so high?"

"Did someone unplug the vaporizer?"

"Where are the proper latex examination gloves?"

My penis shrunk up into my thick pelvis. It ran and hid. The lead pharmacist, a lady with a redheaded permanent and aqua blue eye shadow, took over inquisitor duties. Her perfume froze in the air, and the rest of us were trapped in a perpetual gag. A sea sick "in" crowd.

"Who supplied you with all the SuperChill?" she asked. Her tone was straight out of The Brady Bunch. Florence Henderson, disappointed and expecting more.

“I don't know,” I said. My eyes were blindfolded with Dr. Scholl’s orthotic insoles. Flat Foot Protection on clearance.

"We can do this the easy way," Mama Brady flirted, "or the hard and dirty way." The other pharmacists probably had their own ways with words. If I could have seen them I might have kicked my legs.

As soon as my eyes were uncovered, I spit as hard as I could. Warm, dry spit at their wide faces. 


\section{Track 44}

It is difficult to feel sorry for people with washed-out fluorescent skin.

I stared up at the bright light tubes to keep from being broken - an old military technique I had practiced in the chair at a dentist's office. Counting out breaths from my bloated abdomen while the Doc worked his drill bit. Elevator music pumped into the clogged workspace like antihistamines. Celine Dion freezing to death. Dion and the Belmonts wondering in harmony. Pervert pharmacist snake handlers coaxing me into peeing myself. Then laughing and dancing at the same time to the soft music.

"I said I don't know who gave the Chill to me. Some old white man with a cleft palate. Nah, with a cleft chin. He said he needed to unload it fast and was willing to sell it to me on the cheap."

“How much did you pay him?” Mama Brady asked, checking her reckless makeup in a pocket mirror. Throwing shade all over the place.

“A full week's allowance," I said, money on my mind.

"How much do allowances run in your neighborhood?"

The question was a socioeconomic demographic indicator meant to embarrass me into talking. Like we didn't know we had nothing.

"My mother drops me a five-spot when she can scrape it in change from the bottom of a school desk."

The pushers busted out over my meager inheritance. Hurled insults like decimal points or remainders. Ruthless in their calculations. My hairline receded at the taunts. 
I played 50 Cent's "In Da Club" music video over and over in my mind to go someplace else scientific. Where experimentation took on a party feel for a captive audience. The other pharmacists could hear the music, too, and started jogging on treadmills they kept plugged in for slow periods between prescription refills. Rows of pill bottles as big as pickle jars on the bookshelves. Case files of addicts and suspected pushers. Stacks of D-ring binders.

We got back to funny business.

"You say you don't know the name of the man who unloaded the SuperChill on you?" Mama Brady wanted answers like a pension check or a pocket protector for her laboratory getup.

"No," I sneered, “ and I don’t have a white pages handy.”

"Watch your mouth, you black son of a bitch."

A pimp smack from the depths of hell met my cheek on bad terms.

"Excuse me, I'm here to pick up a prescription."

An old white woman had snuck up to the counter without anyone even realizing it was operating business hours already. One of the meaner looking assistants went to help the woman. She nodded and smiled in my direction like, "It wouldn't kill you to put some meat on your bones." I nodded and smiled back, noting the patronizing concern in her lipstick. She took her brown paper lunch sack full of blood thinners and shuffled towards the shopping cart corral.

When the old woman was out of listening distance, down the kitty litter aisle some ways off, the inquisition continued in earnest. Everything on a need-to-know basis.

"Where did the transaction take place?" Ol' blue eyes asked, like she needed to know and now. I tried to think of a location a middle-aged white woman would buy.

"Outside the corner liquor store on my block," I sang. 
Her ears perked up and relaxed away like she expected it all along. Like everything she'd heard about the 'hood had been proven gospel.

"What's the store's street name?" she asked, smug.

"K-9 Wine and Spirits," I said, "Where all the real road dawgs get their drink on. Now accepting EBT.”

“They sell state-sanctioned Lotto tickets there?"

"24/7, like it's the only way out."

Mama Brady was satisfied and let it show. I couldn't have made her prouder if I was her oldest son on a football scholarship.

"We've got the information we need," she smiled. "Cut him down, boys. We're about to hit it big."

Two goons dropped me from the rafters with the Jaws of Life, and I sank into the box of light bulbs till they shattered and lacerated up my sides. Blood mixed with halogen and potential energy. But everyone had seen worse in medical school and filed out the exit unimpressed. Mama Brady flipped the "OPEN" sign to "Be Back At" with the red plastic clock arms broken off the brass chad nose, and she and her flunkies continued the mission to take back the racket that was rightfully theirs.

\section{Track 45}

I flew off the handle. I wanted Richard Pryor's head on a silver platter. Chemical burns and all. A chew toy for my Pomeranian.

Check that, I wanted a former president of the NAACP on the phone. For him to take responsibility for my scars.

I wanted dreadlocks I didn't have to feel guilty about the next morning. Freedom 
from the -ism's that broke down Babylon.

Everyone got everything they ever wanted except me. Suburban logic played out like an early bird special.

Nothing seemed to equal what it cost.

\section{Track 46}

Macho Man was the radio host with the most. They gave him his own little regular show slot on Wednesday's at midnight. Local plumbers advertised with him. People called in and requested their favorite rap songs from the early year-2000s.

“Hello, caller! You're live on WHIP 95.9 with the Macho Man! What would you like to hear tonight?"

"Hey, Macho Man, this is Alamena, from Harlem. Longtime listener, first time caller. You'd be my big daddy forever if you played Nelly's 'Country Grammar' up in herre.”

“Oh, Alamena from Harlem, you don’t even have to trip, girl. You know I got you on that classic St. Lunatics shit.”

When the beat dropped, Macho took his headset off, fiddled with some lit-up telephone buttons, and sank back in his studio chair. He looked like the same little Stuart Smalley Saturday Night Live character I had grown up with in the Rust Belt. Nothing had changed.

"Who would've thought two small-town white boys would make it this far?" Stuart asked the dead air. He tried to bear hug the studio to his small chest.

"Not me, brother," I said. "Certainly not me." I thought back to both of our serious addictions. Mine to horseracing and speed chess, his to pussy and good weed. We had broken them the only way Ohioans know how: by kicking the Devil in the teeth with a steel-toed boot. 
Stu had taken up tai chi in the middle of a neighbor's soybean plot. I registered for a public library card.

"So what brings you to my neck of the woods," Macho asked, propping his heels up on the desk next to a typewriter and a pack of Dutch Masters cigars.

"Free advertising."

The truth had a way of slipping out when I was around old friends.

Macho unwrapped the cigar package, pulled out a blunt, sliced it open with a razor blade, and emptied the cheap tobacco into a garbage can under his desk.

"For old time's sake?" He looked at me like a bloodhound.

I reached into the crotch of my boxer briefs and produced a Ziploc baggy of Chill. Tossed it into his waiting lap. He smiled like a con man. Poked a hole in a corner of the baggy with a hatpin until the powder drained out slow as an hourglass. He held the pierced corner over the empty blunt and let the SuperChill fill it clean up. Tossed the empty baggy in the garbage, too.

"Hello, caller! You're live on WHIP 95.9 with the Macho Man! What would you like to hear tonight?"

"Hey, Macho Man! Big fan of your show!"

"Thanks for the love, y'all, thanks for the love!"

Macho rolled the blunt tight around the Chill, licked the seam shut, and torched it solid with a Zippo lighter, blushing like the King of Rock and Roll.

'I'd like to hear Lil' Jon \& The East Side Boyz, 'Get Low.' Got low to it myself at my high school prom. Backed it up with the female that would eventually become my wife, ya heard?" 
"My man! Go 'head boy! Here it is for ya, from the windows to the wall, right here on 95.9 FM, WHIP, Da Whip!"

The nostalgia was too much to handle, and I threw up all over the studio carpet and my fresh new sneakers. Stu didn't care 'cause he had sparked the blunt and was taking Denzel Washington-sized hits off it. I didn't try to slow him down. I knew better than to try to slow his roll.

Once, in high school, Stu took his daddy's old Chevy pickup out to play chicken with Pete Rose on Rural Route 4. Rose being the main man when it came to hustlin'. Both boys sat in their respective beaters a quarter-mile apart, revving their engines. Poodle skirts covered the crop fields. Acid washed jeans hung from the new telephone poles. Some bitch waved a checkered flag for Stu and Pete to kill each other, but Stu took the keys out of the ignition and dragged its sharp metal ruts against his knuckles until they bled.

\section{Track 47}

Ocho wanted to make our love thang permanent.

She said, "We're slipping through each other's fingers like brown sugar."

I didn't know the right way to disagree, so we grabbed a handful of fountain pens from her mama's apartment and got to walkin'.

"Tell me I'm the only one, Christian." She had tree branches in her eyes. Aluminum foil blew in the streets. All the fire hydrants had their tops blown off, and kids redirected the force where they wanted it to go. I tried to keep pace.

"I don't even know how to count to two," I said. 
She swooned until we both tripped over cracks in the sidewalk and fell into my arms horizontal. Shots were fired a block over. A mother screamin' shit about "My baby's dead and bleedin', they shot my baby clean through the fingers like brown sugar."

Ocho and I kissed long and violent on the ground. Nothing else registered. My hand was working its way up her silhouette when she stopped me short and rushed, "We're going to be late for our appointment."

We hurry-walked past the barbershop with old heads talkin' Cincinnati Reds baseball and the highest quality shaving cream for white men.

"Gillette is the best a man can get."

"Bust through your beard with Barbasol."

"Nair for short shorts."

The shop stunk like fried shrimp. Past the liquor store with Blanco faded out front next to the garbage cans. Ocho wanted to stop and ask for his blessing. I gave in.

"Hey, Blanco, man, what's really good?"

The old polar bear was curled up in the fetal position, sucking on his dirty thumb. $\mathrm{He}$ stopped sucking and bolted alert and upright when we approached. I saw Canaan in his eyes. His black beard glistened in the sun.

"Hey, you kids holdin' any of that Cool Off shit?"

My asshole shrunk, scared. Were we that obvious?

"Damn, Blanco," I said. "Can’t a brother walk down the street with his girl without getting' hit up for dope?"

He played Bashful until my shoulders stopped hunching over angry. 
"I'm sorry, lil' white chillun'," he moped. His demeanor shifted proper. "What I meant to ask was, 'Do you know where a poor, old American war hero can get some sweet chemical relief from this cold and lonely mulatto world?'”

Ocho softened at his change in tone and nudged my behind like a smoke signal.

"Now, that's better," she said, twinkle-eyed. She kept her hair natural as a way of spiting the humidity and telling Halle Berry to suck her black dick.

Blanco looked up at me, giddy. He made his scratchy white palms into a birdbath.

"I don't know, Blanco," I said. "I'm getting a little light in the stash to be handing out freebies on a weekday."

He jerked up to his knees, agitated.

"Whoa, whoa, whoa, lil' brother. Ain't nobody said nothing about no 'freebies.' The whole neighborhood knows Bomber Blanco don't accept handouts from nobody, not even the Department of Veterans Affairs. Nah, I have something to offer you in return that will change your whole 5-year plan."

Ocho looked at me like, "This nigga must be crazy," but she half-smiled and winked, so I turned back to him and said, "OK, what you got for us?"

He rubbed his hands together and snapped his bent fingers like a used car salesman.

"For you two Eden dwellers, I offer the finest fortune reading this side of Paradise." He licked his lips like a billy goat. "A glimpse into your future."

I wanted to bust out laughin', but Ocho's serious eyebrows kept me upright and straightfaced.

“Where you hidin' the crystal ball, Blanco?” I asked. "In that silver flask under your armpit?" 
He squeezed his elbow to his side to hide his hint of bootleg hooch.

"Nevermind that, lil' white boy," he said. "All I ask is a mere peek at the palm of your left hand."

I hesitated to stick it out to him, but Ocho nudged me again and I had nothing to say to the rain clouds over the gas station. Black as Texas tea in all directions. I forked over my palm, and Blanco pulled a pair of reading glasses out of his field jacket pocket and set them prim and proper on his nose.

“Hmmm." His breath settled warm on my skin as he inspected the lines and ridges of my palm. Holes in the toes of his tennis shoes. His sweatpants held urine stains at the knees.

"So what's the good word, Blanco?" I was getting impatient and wanted a Deluxe Whopper with extra mayo or a General Electric top-load washing machine from Sears.

Ocho scratched her legs together and spat.

Used cars screeched up and down the block with thorns in their paws. Little street kids played Run, Catch, Kiss with their floppy pink tongues out. Blanco kept his eyes on the prize.

“Oh, no, no, no.” His voice became a wine cellar. “This can't be life, lil' brother. I can't be the one to tell you this E! True Hollywood Story."

I pulled my hand away from him and jumped back a few feet. Ocho took on a Jodie Foster interrogation look.

"Whatchu mean, Blanco?" I asked. "Whatchu think is going to happen to me in some far off future?"

Ocho started to cry black tears all over her cheeks. Her knees wobbled like she couldn't take much more of this. 
Blanco cleared his throat. “The Weavers of Time have put somethin' awful on you. Worse than they did Sisyphus or Dr. J. with heavy rocks."

I needed direction from an interstate roadmap folded into sixteenths.

"If the lines on your flesh are any true indication," he took a pause out of Knute Rockne's playbook, "your head won't hit the pillow tonight until you're dead and buried in an unmarked street grave."

I wigged out something fierce.

Ocho damn near fainted with her eyeballs in the back of her skull. Blanco kept his pleading hands out in front of him like, "Don't shoot the messenger in the head."

I slowly untucked the baggy of SuperChill from my hoodie pouch and heard the rain pelt its plastic. I dug two fingers in, brought out a scoop, and rubbed it into my teeth and gums until I couldn't recognize Blanco's dirty eyes. His face blended into the gas station's neon sign, and I took him for a pitiful stranger.

I dumped a half-ounce of Chill into the pits of his hands and watched the downpour turn it instantly to simple syrup. He went to lapping it up with his tongue, greedily taking all of the drug into himself as quickly as he could. Just in case the rain let up and he was found out to be a wino fraud.

Ocho couldn't be comforted. Her big shoulders flexed themselves overveined, and she pulled away from my weak attempt at a tongue kiss of our own. She just kept screaming, "Now more than ever!" and grabbed at my hand with her teeth. She dragged me like a show poodle block by block, neighborhood people wondering if I kept my mind at home in a piggybank.

I tried reasoning with her. 
“Blanco's just an old fiend with dill pickles for brains. He would've told us anything to get some Chill in his system."

But Ocho wasn't havin' it. She squeezed the fountain pens between her knees so tight I worried they'd shatter and that we'd get cited by 5-0 for littering under the influence.

The rest of the dope in the baggy might've been America's favorite snack cookie for all I knew. Things felt like they were leaning back. I thought of never reading eulogies at my stepparents' funerals. Never graduating from the streets. Never passing along my dirty genes to a toddler wondering which Piagetian stage dealt with severe dissociative tendencies.

\section{Track 48}

We pulled up outside Fatty's Tattoo Parlor, exhausted and sunburnt. The rain never bothered to stop and cool us down. The parlor's windows shattered into a jigsaw puzzle. Time crept all over the place like a silverfish thief.

"This is what we're here for." Ocho had me by the sleeve with her eyelashes. There was only her and the rise of the t-shirt over her black belly button. An encore was called from a hitchhiker standing out in front of the parlor with his thumb in the air, useless. Ocho opened the front door.

"Fatty in?" she asked.

She sounded desperate in the eleventh hour of some smart shopper marathon. A blonde underwear model with a wire clothes hanger pierced through her nose acted as the receptionist. Secretly, she was an IHOP waitress waiting to make the big bucks after a nickel and dime raise.

"Third stall on the right." 
She pointed a lazy manicured finger while flipping through the latest issue of National Geographic. I only spent a second staring at her breasts. She noticed and didn't stop me, only bent over the glass case full of sterling silver nipple rings a bit more.

We went down the parlor's center aisle with partitioned-off cubicles for each artist. The spaces were small and filled with space junk. Whimpering clients sat bent over in each stall with Jiminy Cricket-looking motherfuckers needling ink into their skin.

Psych, each of the artists wore an embroidered Hell's Angels leather jacket with their name sewn over the heart. Bulging eyes focusing on the points of the needles drawing samples of blood and leaving tar behind. Some of the shapes and sayings in the clients' skins were expertly crafted and showed only minor signs of infection. Others wore pus like a fur coat.

"Fatty," Ocho called, "We need lifemarks pronto."

My girl didn't mess around. The man in the third stall on the right was hunched over a microscope in the corner. Synthetic inks laid out in order of molecular density on the color spectrum. Autographed headshots of Las Vegas showgirls framed and hung delicately to the floral wallpaper.

No, the images were photographs of P.O.W. executions after impartial military tribunals. One was a man hanged from his neck in a Nazi uniform, kicking the air underneath him that wouldn't harden. Another was a French revolutionary with her back against the wall facing a firing squad loyal to the Crown.

"So what's the word?"

Fatty didn't straighten from the microscope or turn to look our way when he spoke.

"I want an oath to a religious lifestyle written freehand," Ocho said. "And my man friend wants an eight ball inked over his love muscle." 
She dumped her collection of fountain pens on the cubicle floor. Overhead light from the glass ceiling reflected off the nibs. The shimmering shook Fatty up, and he swung his slight body on the swivel chair supporting him. Rabbits could've gnawed through the bones in his wrist. Depeche Mode was playing a song on his chest. Superman figurines standing strong behind his inks didn't have much to do with anything. He took one of the pens from floor and dipped it into the deepest black on the workbench.

"Lift up your sleeve."

He never looked me in the eye. Only stared at the patch of flesh under suspicion. I did what I was told. His thin red moustache strained while he stared the finished image onto me ahead of time. Ocho held my clammy hand next to her cheek. Fatty, in his red canvas sneakers, tapped rhythms into the parlor's floorboards.

"This," he said, "is going to smart a bit."

He plunged the pen tip into my arm, and Ocho let out an orgasmic moan when she saw the first of the black in me. Her toes curled around mine. A clock radio on a shelf above Fatty's workbench was the throne to a Queen Latifah collectible bobblehead.

I screamed like Seal. Scars across my face and arms.

No, not scars but sounds I knew coming out through my features.

"You look pale," Fatty said.

"Yo mama."

"Maybe you should lie down for a bit and regain your color."

"Listen to him, Christian," Ocho urged in a whisper, "The man's a professional." 
I bent to put my head between my knees and heard the parlor door kicked through and open. Coat Hanger screamed her throat out to gunshots and the thick smell of ammonia. Ocho fainted into my line of sight. Her chin cracked the floor at my heels.

She had bitten her lower lip off in the fall. Fatty let the ink pen drop into her bloody mouth. He kicked her in the forehead on purpose when he bolted out the open cubicle doorway and headed towards the exit at the opposite end of the aisle.

Twelve shots caught him in the back, and he hit the deck dead. No one recognized the shooters. Some local kids who worked part-time at an ethnic neighborhood grocery store.

Scratch that, the shooter was the valedictorian from Ocho's private Catholic high school for up and coming young ladies.

Nah, the suspects were identified later as the surviving members of the boyband trio, LFO. Since their polyamorous relationships with Jennifer Love Hewitt had hit the skids, they were looking for anything to bring the thrill back around, one last time.

Fatty had newspaper for carpet, and the headlines read, "Pop Goes the Weasel," and underneath that, "Teen Idols Blast Through Tattoo Shop in SuperChill-Fueled Rampage."

It was a smear campaign.

Blood accumulated in the unhealthiest parts of my brain. I treated the bend over like a reservoir. Sensations rushed into various defensive positions. They considered the tactics of guerilla warfare. They negotiated a collectively bargained peace treaty with a landlady who owned a significant portion of waterfront properties in a swanky residential enclave called "The Lobe." Taxes were more than I make in a year. Ad space was sold to local religious extremist organizations who believed newsprint was the new after school special. 


\section{Track 49}

Connie was a hot water cornbread bakin' woman who felt the presence of the LORD. She sat in church every Sunday morning promising herself to Jesus Christ the Savior. Every other morning she sat in a booth in a greasy coffee shop sippin' decaf and reading the covers of books God writes with white bolts of lightning.

I sat next to her with a glass of $2 \%$ milk and three plastic straws in a row. Two napkins folded into birds. One paper napkin folded into a fighter kite. I scooped handfuls of broken glass onto the straws lengthwise. Julio was behind the counter stuffing Tootsie Rolls into the butter croissants. Even the assistant manager with a back brace knew he was a flake. King Nebuchadnezzar sermons sounding on the stereo. A flier hung on the community corkboard asking for a lead guitarist to audition immediately in Julio's garage for a spot in his Jackson Five cover band. They called themselves The Schoolyard Boys and only played cuts from made-forTV movie soundtracks.

Connie set her study bible on the table and walked over to the board. She pulled the flier off and push-pinned it into her breast until blood peaked through her blouse.

"You know how to wail on an ax, babe?" Julio had his mouth full of guacamole.

"I know three chords and all of 'Stairway to Heaven'," Connie said. "Will that fly?"

"Fly me to the moon or somethin'." It came out more awkward than Julio had planned.

No, Julio asked Connie for her home phone number, but Connie was aired out on the café floor. She didn't take to the bloodletting, and it showed in the blue to green veins in her wrists.

I bent over to check her pulse, and it was Charlie Parker. A toe-tapper. One of the uptempo gigs not meant for white people. It was well known during Bird's lifetime that he refused 
to play for audiences of self-satisfied white men. Once, he cancelled a show at the Cotton Club because a waiter in the front rows looked at him like an Uncle Tom.

Connie had the Devil's music in her blood. Her pulse slowed to an old-fashioned donut beyond the glass counter. I wanted to makeshift resuscitate her with what was on hand.

“Julio," I shouted, “Toss me an apple fritter and a hot cup of regular to go."

"No, give him a half-dozen chocolate twists and a quart of orange juice."

Pepper, the assistant manager, was being an asshole from across the shop, confusing Julio's small, white mind. He adjusted his apron and hairnet and tried to get his bearings.

“Don’t listen to her, Julio," I reassured him like a mother hen. "Just the apple fritter and coffee." Connie was sleeping with the enemy, and I thought a sugar-caffeine kick might wake her up to the error of her ways.

"Now what does he know about customer service, Julio?" Pepper had her A-game lip first thing weekday mornings. "Toss him the twists and the OJ and see what he has to say about it."

Brew steam shot out everyone's ears like a Tom and Jerry Saturday morning cartoon.

"I'm not playing around, Julio." There was a speck of desperation in my voice. "Get me that fritter and regular, we're losing her."

Connie's pulse was turned way down low, so that customers had to feel it in the seats of their chairs. Tables shook slightly enough to slosh coffee into rings. Julio was mesmerized by the drying circles under the mugs he'd have to clean with his own spit and thumbs.

“Snap out of it, boss!" I hollered. "Get me the coffee now, goddamn it! She doesn't have much of her own juice left." 
Pepper might as well have been the Devil's advocate in a long black raincoat. Slinky lingerie underneath, kept in by the leather belt bow-tied around her average waist. Julio's neck opened like a hinge, but he couldn't say anything worth bragging about. His pants warmed in a puddle on the front from the high-stress decision-making. Fumbling over his minimum-wage duties.

Chico finally hopped over the counter with a Costa Rican blend smoldering in a Styrofoam cup. The superhero cape around his neck proved effective in maintaining his balance midair and providing a dramatic flair that keeps the customers coming back for more. Everyone in the shop updated their social media home screens from their wireless devices. Exclamation points all over the place.

I threw the coffee in Connie's face and licked my lips. She didn't respond at first, but bolted upright when the heat sunk into her eyes and nostrils. The corners of her mouth smoked and curled.

"What do I owe ya?" she asked, thankful and disgusted to be alive again.

“This one's on the house." I was high on Chill and full of myself.

The roof caved in.

A rafter beam fell across Connie's neck. Julio was laid out under a boxy air conditioner unit. Chico had never been there to begin with. Pepper pulled a fire alarm lever she found lying in the roof heap. A paper crane flew out the back exit squawking its fool head off. The authorities were called.

"What the hell happened here?" a first responder asked.

Two butterball policemen rolled through the wreckage laughing their asses off, unimpressed. Like nothing valuable had been damaged. They dusted themselves clean and 
cruised over to the Officer's Club for Ballpark Franks that plump when you cook 'em. The second the pigs left the block, some hood rich cronies from the Jets gang started some shit.

"West Side, muthafuckas!"

Hollow tips tore through the demolition site like Chris Rock live at Madison Square Garden. His teeth and earring shining like hot lead. Bringing down the house.

Pepper got caught in the crossfire between the eyes and fell over drinking an iced latte. I took one in the chest side that doesn't count. Things were out of key. I asked around for a tuning fork.

Chico passed me a pudding dish full of tuna salad. I could smell the Hellman's mayo and freshly diced onions in diamonds. The bullet wound was nothing I couldn't handle on a bad day.

"Pepper," I hollered, "stop fooling around and call another ambulance."

I didn't pay attention to her dead in the rubble.

"Julio," I hollered, "toss me your cell phone so I can ring the white coat angels one last time."

But he was out cold under the AC unit.

Public Enemy's “911 is a Joke" wasn't playing on the shop stereo. All the electrical wiring was dried up Ramen noodle bowls. Sparks were flying on the cheap, but the stars weren't out yet to talk any mess.

"Connie," I hollered, "it's come to asking the Big Man on Campus for some of that divine intervention shit.”

I swore I'd never ask God for a favor again after everything fell apart during freshman year of high school hazing.

"How ‘bout one last Hail Mary,” I hollered. "For old time’s sake." 
Connie's neck was the stuff of legends, her hands relaxed and open. Two eyes were tattooed on her palms, one eye tattooed on each. The right eye on her left palm, open and looking dead ahead. The left eye on the right palm, winking shut. Between the two of them, I took Connie for a thief telemarketer and hung up in her face.

My pants fit too tight around the waist, but the gangster drive-by kids didn't give a damn. They rolled off in one of their father's Jeep Grand Cherokees, flashing sign language I wasn't familiar with. I could only identify the movements that spelled out the letters of my first name.

\section{Track 50}

Wind blew through houses built out of rain and sawdust. It was the beginning of the wet season, and people huddled together under awnings to warm themselves with newspapers and cigarettes. I met Tony Bennett that way, his big nose in a book.

“Whatcha readin', pally?" I asked.

“One Hundred Years of Solitude." He tipped his cap like a good ol' fashioned Yankee gentleman.

"Sounds like a New Wave band from the 80s" I joked.

"It is that." He raised his lip like an annoyed stranger.

No, it was Ingrid Bergman under the awning. And she didn't see me but Jethro fresh off the turnpike. I watched the chance meeting from my apartment window with binoculars. From two blocks away, munching on a cheeseburger with no pickles. Nothing preserved.

Jethro made the first move.

"Say," he said, "do I know you from somewhere?"

"No, I don't think so." The polite brushoff of a Southern debutante trying to find her way out. 
“I don’t know," Jethro said, unconvinced, “you sure do look awful familiar."

Ingrid puffed her feminine cigarette like a show poodle and gave in a little.

"I've been in a few small pictures," she cooed. "I'm sure nothing you and your friends would have seen.”

“Try me." Arms crossed at his chest like a gumshoe. Inquisitive and young.

"Oh," she mumbled, blew the smoke from her gaunt cheeks, "a Warner Bros. picture called Casablanca."

"Never heard of it," Jethro spat.

"How about Notorious, directed by Alfred Hitchcock?"

"Nothin' doin'."

"For Whom the Bell Tolls?" Ms. Bergman was getting mad skeptical.

"Never heard of it, lady."

"But it was nominated for many awards!" Pissed off in a heartbroken starlet type of way.

"I don't get to the theater much these days," Jethro admitted, kicking at the wet sidewalk with his shoe.

"But why in the world not?" she shouted, incredulous in costume jewelry.

The crowd of huddled pedestrians warmed themselves in a heartbroken starlet type of way. Their own cigarettes and body heat. No one else was looking or listening, their thumbs busy stuck in Chinese finger traps.

"I don’t get around much anymore," Jethro said like Nat King Cole, "since my main girl up and walked out on me.”

“Oh, my poor boy!” Ms. Bergman was salacious and perfect. "That's terrible! I'm so sorry for you. What was your girl's name?" 
"RuPaul Andre Charles." It took everything he had to get the syllabes out. Ms. Bergman was sold.

"What a marvelous name. Was she in show business?"

Jethro's stomach grumbled and thrust. His throat itched with tonsillitis. The most melodramatic pause of his short life.

"I guess you could say she was the best performer in town."

A jazz combo emerged from the center of the huddle and played an up-tempo number. The awnings started to lower. Candles were lit on bar tables. Waiters brought bowls of dryroasted peanuts. A spotlight shown on Malcolm-Jamal Warner reading a slam poem. He had gained significant weight in the streets since the last time I'd seen him. Brothers knew he was not the kind of nigga you should try your luck wit' or fuck wit'.

"I'm on top of the world," he recited calmly, "when the after school program gets the snack portions meted out in like fashion. Paupers poking each other in the Rice Krispie Treat, calling each other Kunta Kinte like they done known each other forevah.

'Emphasis on the been knowin', since in the end we gon' be judged not by where we're from, but who we've,” he reached his hand out to catch a water bug, “ ... released.” He squeezed the bug dead.

The spotlight died in a blink-off, and Jethro went fangirl apeshit himself, asking for an encore, asking to meet up with MJW at the after-party, at the after-after-party. He had never been so moved.

"I've never been so moved," he cried, wiping shiny tears out from under his black eyes. He kept his chest muscles flexed the whole time so as not to come off too North Side pussy. Ingrid Bergman appreciated his dedication to the hard-knock life. 
“What are you doin' a little later, flyboy?" She was a saucy sex kitten sucking fancy restaurant ketchup off her fingers.

"That all depends on the record collection you keep between those thighs."

It didn't make sense, but Jethro played it cool as an ice cube tray. "That is, uh, I'm all about makin' you spin the right way."

She was spellbound in a fox fur coat. Hadn't ashed her cigarette since before the slam took off. Hot and bothered in a heartbroken starlet type of way. Diggin' Jethro's flavor till it ran out.

"Do you know what to do with these?"

She dangled her Coupe Deville car keys from her pinky finger.

Jethro thought to rake them down her bare back.

"My mama didn't raise no fool."

He started taking off her coat and placing the keys between his knuckles like cat claws. Ingrid looked confused but went with it, the high of a younger man's thick body odor filling her up proper.

Jethro was about to bring the soft metal to her skin when a white limousine pulled up to the corner and rolled its rear window down.

Puff Daddy and the Family were kickin' it like they used to in the back seat, poppin' bottles and clownin' on each other somethin' awful.

"Y'all muhfuckas know where a nigga can get some Grey Poupon?"

His posse fell out.

None of the white folks under the awning knew how to answer him since their hands were full of National Geographic magazines and seltzer water. 
Puffy took the silence as a sign of disrespect.

Two fly girls with their titties out whipped their hair back and forth and hollered, "Blast these fools!"

Rappers give in to peer pressure more easily than the rest of us when it comes to death threats. Jenny from the block was crying somewhere on a queen-sized mattress. Giorgio Armani was taking his own life's work excessively serious.

Puff pulled a Glock out from behind his false teeth and started spraying single shots into the small crowd. Most of 'em had seen it coming from a mile away and started runnin' the moment they heard a black man say, "Poupon." Jethro didn't subscribe to racial profiling. Ingrid Bergman did, but she forgot this one time.

It was a costly liberal mistake.

All the black cats in the limo were rollin'.

"You see those muhfuckas bleedin'? Real niggas don’t die!"

Puffy had a swollen egghead. His ego was up out the sunroof, shinin'. Ms. Bergman held her girdle line to keep her tummy tight, to keep from spilling her guts.

Jethro had bullet holes in the shape of a heart over his heart. True to form red. Violent hues. Broads from around the way catcalled him like, "Hey daddy, why don' you spread some of that good lovin' our way?" Busters were puttin' Ingrid on the spot with, "Honey, you got the kind of body that'd put a hurt on a brother." She couldn't sing a lick back.

I counted the number of casualties on my fingers.

"One ... two."

Jethro and Ingrid, sittin' in a tree. 
The limo drove off like a stock car race. White Southerner tourists watched it from the sidewalk with their mouths hanging open. Some of the bolder men had next week's paycheck ridin' on the number so-and-so car. Their dicks hung lower from the acceleration. Engine heat comin' off their wives' pussies strong enough to toast a hot dog bun evenly on both sides.

A specific Cracker Jack housewife on the scene didn't have much left to lose.

"So help me God, I love when they let it ride." Buela Mae hadn't worn cotton panties in years. She had her ring finger in her mouth. Swirling her tongue around it like hors d'oeuvres. Puffy didn't shoot at the rednecks 'cause they weren't worth the loss in sales. Buela Mae with "Property of Bad Boy" tattooed across her pelvis. She rubbed the lettering to rev herself up.

\section{Track 51}

Rhinestone squawked from her birdcage. Shitting on scraps of newspaper or Vogue magazine. On the models whose attitudes she didn't care for. I walked over and fed her a chunk of honeydew melon. The skin of a banana. Grapefruit segments with pulp. Carrot tops. A hunk of baloney sandwich. A dollop of sour cream.

A mountain of SuperChill dug its way into the kitchen table. Nah, a plateau. I looked at it like a volcano. I pounded my feet on the apartment floor trying to make it erupt. Rhinestone shook her tail feathers. Picked pulp from her dapper breast. A ridiculous queenpin.

I sat at the table and ordered the scale, baggies, twist ties, razorblades, and prescription pads in relation to the way they made me feel about myself. The scale being closest due to its digital display. The razorblades farthest away with a dull hopelessness. The SuperChill not factoring into the process because product don't matter to a true G. "Never get high on your own supply." Rule number four in Notorious B.I.G.'s ten crack commandments. Underlined twice in red pen. Bullet pointed. 
I licked my finger and stuck it in to make a cave. A place for weary travelers to sleep on their journey to the Great Beyond. My finger came out dusted. I stuck it in my mouth and swallowed bitter. My tongue knew its way around. It was left to its own devices.

My fingers weren't mine almost immediately. I didn't have any hands or anxiety about it. I thought about an anxiety attack as it had been described on Wikipedia. I compared the description to something I had felt in my lungs while watching reality TV alone as a kid.

A perfect match.

The thought didn't register. There was no use having a calculator for a head. Even if it was fair and balanced. It wasn't about right or wrong anymore. It didn't have to do with a flavor profile or return on investment.

I sat without a proper mind for days.

In the time it took, I shoveled the SuperChill into small piles with an American Express card. The piles into discrete $\mathrm{CD}$ cases with the album booklets in mint condition. Top resale value. Nothing to shake your head about.

My father sat next to me at the table to help with the facts and figures. The weighing and recording the weights of the baggies in the ledger. How many baggies were filled and what we stood to make from the operation. The perfect father/son, $60 / 40$ split. I would take the 60 for sitting through the group therapy. He bought the 40 with his company's Gold health insurance plan. He never said no to a bottom line. He called his stockbroker by his first name:

“Lev, I've got a new jack swing I'd like to add to my portfolio ... No, this has noting to do with estate taxes ... No, I haven't talked it over with Carol ... Because she doesn't know shit about investing, Lev! ... I don't care if she graduated top of her class Harvard Law! ... Because it's my money, and I'll do with it how they do it in the movies! ... Well, like Scarface, for 
example! ... Yes, I have watched to the end! ... Yes, I am referencing the scene with the large desk! ... Yes, I have considered arming myself! ... Well, if you must know ... then, yes, I am armed as we speak ... Yes, the model you showed me from the rap video ... No I haven't considered any video girls to help out with the business! ... I don't care if sex sells! ... No! ... No, I'm not disagreeing with you that I'm lonely ... Well, I just don't see how my Saturday evenings have anything to do with it! ... Sure, I remember what it's like to be young! ... No, I don't think Christian would mind having them around."

He hung up in a huff. I stared at the empty chairs around the kitchen table. Squeezed a stress ball between my fingers and calculated the odds of getting out of the business alive.

"A million to one," my father said, floating in the air like Danny Glover in Angels in the Outfield. His facial hair started falling out and drifting down. I worried it would taint the product, so I lifted my body up and umbrellaed the Chill with my hunched back. Arms straight overhead like take-out chopsticks. The kitchen floor covered in rusty nails I had collected from constructions sites on my days off. I liked to walk around barefoot to see what would happen. For the bloody risk.

The refrigerator took on a life of its own. Bills from American Express magneted to the front handle. Billy Idol playing on the boombox.

No, an American Idol mix in the tape deck with toes for buttons.

Kitchen stinking like fish heads. Parasites living in civil communities in the dish sponge.

"What are the projections for next quarter?"

I was talking to myself.

"We stand to take in about $100 \mathrm{~K} . "$ 
My father was in fine voice. His cell phone rang. The table buzzed with anticipation. A kitchen window smeared with pigeon shit. I fed the pigeons corn nuts from my bare hand like they were my own flesh and blood. My father ate a stick of Wrigley's Double-Mint gum to freshen up. He took the call in stride.

"Mike Brady speaking."

He had a Scandinavian accent. We looked nothing alike.

I tapped him on the forearm to ask for a paternity test, but he brushed it off as an elaborate stunt orchestrated by my bitch mother.

"Oh, hello dear," he moaned. "I was just thinking of you!"

Maple syrup dripped from his mouth as usual. His Oxford was a wreck. He looked like a Southern Baptist after a pancake and sausage breakfast benefit. We needed to be redeemed. I scratched at the genetic mystery living in my forearm veins like a double helix while he went at it with moms.

"No, you don't need to worry about that, dear ... Because that's all in the past behind us ... No, I'm with Christian if you must know ... Christian ... Christian, our son! ... Yes, I remember the birth stitches ... I was there, Carol! ... No, you don't have to remind me of the hell I put you through that day! ... Carol, the hospital televisions only had so many channels to choose from! ... Look, I don't see why we have to bring money into this ... Lots of women give birth in common public hospitals just like the one you delivered Christian in ... I know it was the size of a soup kitchen! ... Yes, I asked them if they provided OB/GYN services for the less fortunate! ... You know what their answer was, Carol! ... The only answer you would have accepted and still decided to have the baby there! ... You're damn right I mean that! ... Listen ... Listen to me, Carol ... I don't have time for this. I'm spending quality time with our son ... Yes, 
he $i s$ opening up to me about his personal life ... Well, I guess there's never any way of really knowing for sure if someone is telling you the truth ... I suppose your guess is as good as mine, Carol ... Yes, I'll be home before midnight ... Yes, I'm aware of the thunderstorm ... Trust me, I can hear it right now on the roof, dear ... All hell's breaking loose! ... Goodbye, Carol!"

We took a beat to reflect on our shared family values.

"Who was that?" I asked, feeling coy and greedy in a pair of penny loafers.

My father didn't answer, just rubbed his quadriceps muscles right above the knee in both legs. Crickets nested in his thick eyebrows. I had seen his shoulder positioning on the Heisman collegiate football trophy. He sat there statue bronze.

“Wanna play a game of Sorry?" I asked. I was feeling vengeful. I wanted to rub his face in the living room carpet. He rubbed his face in the pile of Chill instead and snorted up the best he could. I didn't have the guts to stop him. His nostrils took big, bold gags of junk down his throat, and persevered through the coughing fits. An unwavering belief in the power of the drug. I rested my elbows on the table to learn from his example.

The doorbell rang. MC woke up from his sleep across the back of my father's shoulders. He looked like a black cat. Supernatural bad luck.

I got up to answer the door while all the potted plants in the apartment wilted. The television set was on. A PBS program on digestive health was playing for an audience of one: ex-fugitive Dr. Angela Y. Davis passed out on the sofa like she owned the place. Like she was Diana Ross.

"You know, there's a fold-away mattress in that thing," I offered. 
She farted in my face and picked a Sun-Maid raisin from between her front teeth. I could smell her armpits and thought to make a night run to the Walgreen's for Lady Speed Stick. She'd never warm to it, though. Always pushing back.

The doorway had a mind of its own.

“What's really hood, lil’ brotha?" Duke University's own Mark Anthony Neal pushed his arms against the doorframe, trying to turn them into ghosts. I gave him a black bear hug even though we had just met.

"Lord knows it's good to see you," I said. I was smitten with brotherly love imported fresh from Philly.

Nah, fuck that, the Professor in the hallway was beaten unrecognizable and lying in a pool of his own blood. I nudged him with the toe of my Birkenstocks, but he was unresponsive.

"Pop,” I hollered, "Call the EMT! There's a brother out here bleeding to death!" “..."

My father was still face down in the Chill, his own pulse slowing to an unhealthy pace. I itched at my genes like they were going out of style.

"Dr. Davis! Get your dumb ass up and call an ambulance!"

"Is that Mr. M.A.N. out there?"

"I don't know who it is anymore!" I was stark raving. "He's unconscious and bleeding out in the hallway like now!"

“'Cause if it's Mark Anthony Neal, tell him I'm not tryna fuck with his broke ass no mo'."

“I told you there's no way of knowin' who this man is! Just call the ambulance and we'll figure it out later over Domino's pizza!" 
She was indignant as ever.

“Naw, naw, naw. Unh-uh, unh-uh, unh-uh, we ain't doin' that. Not till I know if it's Mark Anthony Neal out there again, cryin', howlin', wailin' 'bout what he'll do if he can't get no more of 'dis again. Bet yo broke ass you won't never get no more of 'dis again. Shoot. Whatchu think I am? Some kinda flygirl on In Living Color? My academic credentials is documented, da fuck's wrong witchu, shit ..."

She let out another smaller fart and reached for the Nacho Cheese Doritos on the coffee table.

I bent down and cradled the man's head in my lap. His lips were busted up crossways, broken teeth filed down to the gums. Peach tree soil in the corners of his eyes. He drooled a little cough medicine. Looked desperate in a heartbroken starlet type of way.

"You Christian?" he whispered, groggy, seasoned like a catfish fillet.

"Yeah, I am." I showed him my driver's license for proof.

“Thank God.” And he died, clutching two Jehovah's Witness tracts in his fists for mercy.

\section{Track 52}

Blackjack shook my shoulder, and I snapped out of it. His tongue purple from Kool-Aid stains. It was a banner afternoon. Folks in the neighborhood had thrown him a tickertape parade.

"Let's go," he said.

“What's the rush?” I asked. My legs felt frail.

"Your brother is sleeping. We're going to wake him up."

"If he's sleeping, things can't be too bad."

But he was talking about the cousin of death for real. 
I stood up, and my father was nowhere to be found. Angela Y. Davis had pebbles stuck in her Afro.

"Where'd my father go, Dr. Davis?"

"How the hell I'm 'sposed to know 'dat?"

She had a brutal point and hung onto it for dear life. Claws for toenails and a bright, bitchy lipstick.

"I’m going out with Blackjack," I said. "I'll be back whenever."

She shooed me out the door with her wrist. I locked the deadbolt and stepped over the Witness's corpse. The crime scene out of my hands.

Blackjack wore his hair like a cracker. Shaggy on the tops and sides, and long in the back. Cherry bombs stuffed in his blue jeans pockets for kicks, and a Tommy Hilfiger sweater from the 90s for profilin'.

"How the ladies treatin' ya, Jack?"

He held his big hands over his face like I had popped the question. His knees bent in slightly towards each other until they touched. He walked like he was churning butter. He ignored my question and handled his.

"Your brother's faded into oblivion outside the video arcade downtown. Cats been callin' you nonstop tryin' to get a word on what you want them to do about it."

I flipped open my cell phone and noted the missed calls, all from Unknown Numbers.

"Poke him in the ribs with a broom handle," I offered, "and he'll probably bolt right back to life." 
I said it like everyone should know the things brothers talked about between the mattresses of a bunk bed—Penny's mortal fear of plastic play spiders. His criminal mischief smile. The warm puddles of pee-pee lingering under the stepladder.

"Already tried that, chief," Blackjack said with his mouth full of Triscuit crackers. "Nothin' doin'."

We walked down my apartment building's stairwell with salt crystals stuck to our lips. We smiled like snow globes. John Henry was passed out on the second floor landing, singing to herself about law school and how things could've been.

“'Sup, John Henry?” I asked. "What’s really good?"

"Hey, lil' nigga boys with ya heads up ya asses," she mumbled. "You both look like peach pie."

“Thanks, John Henry.” We said it together, holding hands.

Blackjack started playing Tetris on his Nintendo Gameboy, and I spent the rest of the stairs looking over his shoulder at the handheld screen, trying to make everything fit.

"Rotate that squiggle twice clockwise, and it'll fit over there in the storage space."

"I know, I know!" He pulled the game his way. "Back up and let a brother show the world how I build and destroy.”

\section{Track 53}

We approached Spinners Laundromat instead of the arcade. No one recognized the difference. The machines all taking the same legal quarters. Balto was at the dryer in the back corner smoking a spliff. Rochester had a new weave and was showing it off to her fly girlfriends. Four little brown boys were poking Penny's dead body with a broom handle. Sprawled out under 
a popup table you could use for ironing and folding your church clothes. I barely recognized his face from the steam rash and bug bites.

"Poke him with this, Andre," I said, "and see if he comes back to life."

Andre poked him with a lint roller.

"Naw,” Brutus scolded, "you gotta poke him harder. Here, I’ll show ya."

He took the roller out of Andre's hand and jabbed Penny right in the gills with it. He coughed back to life, but not really. The boys frowned like they had learned the boring secret behind a magic trick.

Bartholomew pulled out his big gun and said, "Let's use him for target practice."

All the other boys pulled their guns out and stood over by Balto, blazed something fierce.

"I bet I can get him in the kneecap!"

"I'm finna try to get him in the left nostril!"

"I’ve got my sights on your big belly, partner."

"Reach for the sky, Fats Domino."

"Yeah," Ezekiel muttered, "what they said." He was known for his aim, not his mouth.

They took turns firing rounds into Penny, tossing nickels in an ante pile before each shot to see who was the odds-on favorite.

I put my best marbles on Brutus, figuring he deserved the most out of this world after Tragedy took his mama in the middle of the night. Rochester flipped her stringy Indian hair like a skinny Euro supermodel. Her friends all said, "Daaamn, girl, you lookin' right." I agreed with a smile and my chin to my chest. Rochester imagined what it would be like with a white boy. She started vomiting into an empty Tide bottle, and her homegirls had to hold her weave back behind her ears to keep from ruining it. 
I took the stench as my signal to leave.

Blackjack had his sunglasses on backwards.

"Cats around the way say the same thing happen to Penny gon' happen to you if you don't watch yoself."

I was glad he was on my side.

\section{Track 54}

Curtis " 50 Cent" Jackson passed by in his black Cadillac Escalade looking for a fight. I couldn't see if it was him for sure through the tinted windows on the whip. It could've been Mama Brady for all I knew. The Escalade moved on down the block, splashing puddles and running over people's side projects.

Three lug nuts from around the way ran over when they saw me comin'. I knew all three of them ambiguously. I knew their mothers from the DMV counter and their sisters from back issues of King magazine.

"What's good, Mookie?" they asked together, as one. "We heard you got that good shit."

"How 'bout lettin' us lighten your load, traveler?"

None of them understood the real inflammation in my joints. Wearing Chicago Bulls NBA jerseys with big horns flaring out from their shoulders.

"Yeah," I ventured, cautious. "I've got some product if the price is right."

A cat who looked like B.J. Armstrong handed me a thick wad of bills that rustled like string music. I gave in, pleased and satisfied.

"These fine gentleman," I directed to my associate, "just bought the family farm. Give 'em everything we got, Blackjack."

He pulled out his Uzi and sprayed them to death. 
Their bodies knocked over like a well-known bowling alley in the bad part of town.

Psych, Blackjack pulled out a gallon bag of the Good Stuff and tossed it to them like a baby. B.J. Armstrong took a Sharpie marker and drew a smiley face on the middle of the bag. "Now we got another lil' homie," he said, smiling back.

Pepe didn't give a damn. He had Rachmaninoff blasting in his headphones and claimed not to know any Russian. We all knew better.

The boys ran off to Chill with their new young'un, and I told Blackjack we should try to catch a flick at the 10-dollar theater downtown. He scrunched his nose up into a plumb.

"Whatchu want with all that opening night bullshit?" he said. "Nigga, there go an Arby's right there, and I know you could get on some big beef in a minute."

I played indignant.

"None of the value menu items sit right," I said. "Let's go check out the previews and throw popcorn at the subtitles while they runnin' away."

Blackjack wasn't buying it, and I gave in.

The new money had hiccups in my pocket; I calmed it down with soothing race music.

"Nobody knows / the trouble I've seen ..."

“Nigga, shut up!” Blackjack hollered. He was tone deaf.

We walked the drive-thru lane like we'd paid franchise fees and owned the place. Some Chicana woman in a corporate visor went to ask us for our order when a shot rang out from the business district.

Blackjack dropped dead and bloody.

I saw the concrete underneath through the indiscriminate bullet hole in him. The yellow lines used to corral rush hour traffic hassle free. I checked his back pockets for identifying 
documents, then made a run for it. Not trusting the accuracy of a long-range sniper shooter or the nerve of white terrorists.

Old white people sat in their driveways in lawn chairs, airing out the skin on their chests. Not minding the weather so much as when the colored folks moved in and their property values plummeted.

“Keep runnin', boy,” the Vietnam vets shouted. “Ain’t nothin' 'round here for the likes of you."

The wives were the ones brewing sweet tea inside. Mailmen threw explanations of benefits at the ranch-style houses and dropped postcards down the gutter grates on purpose. Just the right size to disappear down underneath the streets.

\section{Track 55}

Almost nothing worried me.

Scratch that, I was terrified to die without letting someone know what I wanted in return. Neighborhoods started blurring into each other. This ice cream shop was the same floral boutique over there. Young black women stood out on every corner, painting beautiful stretched canvases and submitting them to prestigious arts colleges. Landscapes filled with smokestacks and the same chain restaurants where Blackjack died. Rust all through their paintbrushes and elaborate wigs. But it was all them, live and in the flesh. The realest.

None of the lampposts worked for a living. Lost dogs were lost and dying on tear-away flyers. I tried to handle my business. No more shots had been fired from wherever the executives made their decisions behind me. I tore down a flyer of the dog least likely to run away. There wasn't a pen to write anything useful with. I thought to knock on a stranger's door and ask to 
borrow a Bic ballpoint, but all the vets were still slouched in lawn chairs on their driveways giving me the middle finger.

"Fuck you too, then!" I hollered back.

I hated their skin.

All I had on me was the drug money paperclipped into an accordion. I smelled the bills deep up into my lungs. The days they would buy off K-Mart layaway. I took the paperclip off and unbent it straight into a pen needle. Laid the flyer ass up in the street. It took to the rainwater in the road and softened. The paperclip ripped what I wrote into the ground.

The last will and testament of Christian in the streets:

I came into the world with no one holding my ticket to an amusement park. No parents to speak of, no distant relatives with a family tree tattooed on an elder woman's upper thigh. I learned the alphabet from radiator heating, and the Mother of God Orphanage didn't even have radiator heating. When I was old enough to know better, one of the more sadistic Sisters pulled me aside during morning prayers and told me I was the Chosen One who would go on to do many miraculous things for all God's children. She was a vindictive witch with a penchant for soap operas. I braided her hair every night to help her fall asleep. The other children in the orphanage were scabs with no sense of history. The boys massaged their fledgling cocks and forced me to watch. The girls had growing nipples like starfish. We all wanted to go home to an origin place we had never been.

\section{Track 56}

I decided to become a union electrician like my late father but soon grew to hate the sensations of copper wire against my fingers, the feel of constructed walls. In the basement of a remodeled First National Bank I built a pentagram to sell my soul to the Devil. In return, I 
demanded a reasonable pension, some housewares that would impress a woman, and a Duncan yo-yo. The transaction fell through after a simple credit check. Electricity proved to be the way out. I went around sticking myself into sockets to die from whatever felt current, but none of the houses pumped out sufficiently fatal wattage.

I came back to rapping like I always knew I would.

People on the block started with, "Yo! Shut the fuck up!" and kept it up for the first few years. I locked myself in my apartment and wrote rhymes to Dr. Dre 2001 instrumentals ad nauseam. Five sets of lyrics for every beat. Exhaustive flow. I performed the songs with a karaoke machine backup until people dumped their flower garden water from the second floor balconies. Shows were scheduled at pool halls and Shorty's Strip Club. Nobody came to listen or cry me a river. I gave up the whole rapping thing before it even began. My folks forced me to see a shrink after finding my debut mixtape under a mattress and giving it a critical listen.

"You just seem so depressed and moody, Christian." My mother was her practical apron.

I saw the shrink since there was nothing else to do that day. The sky had started to leak, and everyone was either inside grooming their pets or huddled under an awning listening to the Notorious B.I.G.'s Ready to Die.

The shrink was named something I can't remember.

"This isn't about me, Christian," he said. "It's about you."

His business card was a Wal-Mart receipt for fishing equipment. I still have it crumpled up in the pocket of a pair of khaki shorts.

"Tell me more about these feelings of yours."

I told him about sitting in a tree house as a child wondering about the latent functions of a dick like the one my father demonstrated how to pee with. The other things it could do if called 
upon. None of the Oedipal stuff flattered the shrink. He kept signaling for me to get to the source of the pathology and step on it.

I told him about the time I stood inside my brain with both feet all the way in. This piqued his interest. He puffed on a tobacco pipe and twisted the curls of his moustache with a $\# 2$ pencil. Sculptures of babies being born into the world on his desk. Shockingly accurate phrenology charts pointing out the corresponding lobes. A small tin of potpourri filled with buds of California kush. The good-good. I asked him for a sample.

"Oh no," he brushed it off. "I couldn’t possibly."

"But I'm close to the edge." I faked away a desperate sniffle and balled my fists below my eyes in faux distress. Doc wasn't buying it and kept on.

"Did you experience the feeling of a body length zipper up the meridian line of your torso?" he asked, clinically.

"No doubt," I said and pounded over my heart. No lie.

“And did you unzip it?" He looked terrified and obese.

"I didn't need to," I answered. I couldn't stop buffing my fingernails on the cuff of my alma mater sweatshirt like a prude.

"Why on Earth wouldn't you need to?" he demanded. "Patients always try to fiddle with the meridian zipper."

He started spewing some American Psychiatric Association data on the incidence of young black men about my age fiddling with their crotches when presented with the opportunity. Some staggering figure. I didn't want to hear the statistical mumbo jumbo, though, and interrupted him with a weak cough. 
"I didn't touch the zipper," I said, "because it was already opened down the center of me."

The Doc's pipe dropped to the floor and sparked the office rug on fire. Smoke started to curl.

"You're not saying ..."

"Yes," I said, "I was standing inside my brain outside my body reading an issue of Playboy magazine my father had given me on my $13^{\text {th }}$ birthday."

It was a physiological novelty act. Proof positive of a Descartes-style mind-body split.

The shrink scrambled all over the office, stamping out the fire patches and scribbling madly across a prescription pad. He tore the top sheet off, for any amount of SuperChill as often as needed, and handed it over like I'd beat it out of him. He took the high road and encouraged strong patient autonomy.

"Just take as much as you want," he pleaded, "and call my nurse anytime you need a refill."

I safety-pinned the script to the bottom of my shirt like my mother had demanded. Her way of me not losing anything too important to drop. The shrink asked me to go, said he had writing to do for a scholarly article not related at all to me or the circumstances I had just described. There was no reason not to trust his grandfather clock eyes, the way he spoke in rough German when he really meant it. I decided to dip out casually.

\section{Track 57}

The pharmacist at Walgreen's knew her shit. I handed the script over, and she chewed it up in her tight mouth. The generic pill bottle she handed me ten minutes later was retrograde, 
beefed up by our tendency as Americans to bargain shop. 500-count and the size of a water cooler tank.

I strapped the medicine to my back with bungee cords and some elbow grease. Weight took its rightful place on my lower back and bad knees. More weight than I'd ever supported before. Something to be worked with like a fad diet or inhumane levels of guilt and self-hatred. I determined to swallow one pill every hour on the hour until an hour later I was Jack Nicholson in One Flew Over the Cuckoo's Nest. An hour later, I was Gene Kelly in Singin' in the Rain. An hour later I was Hulk Hogan hedging his handlebar moustache and waxing the top of his bald head with racist venom.

The drug had skills to pay the bills.

I thought to continue the hourly regimen and test my confidence at mundane tasks. But it turned into mountain climber exercises on the apartment floor, nervous sweats, and a lack of reality extending forward in a predictable linear fashion. One dose helped me write an innocuous note to my dead mother:

Dear Mama,

I still remember the first time it became frighteningly obvious you had no firm philosophy for how to raise your seeds. Thanks for choosing the fire and brimstone. I've never had to worry about regretting myself like a used car. It's always been so guaranteed.

Love,

\section{Christian}

A second dose helped me when I still couldn't complete a military pull-up on the playground monkey bars. Neighborhood kids laughed until their ribs showed, but my nervous system aligned more closely with the woodchips at the foot of the metal slide. I drank a whole 
bottle of Quakerstate motor oil to see if it would reduce the friction plaguing my free throw shooting hand. Two twin brothers passed me a Spalding basketball, and I buried it at the top of the key with a children's beach shovel. All work and no play.

\section{Track 58}

A day or two into the medicinal therapy, I decided to share the wealth. I didn't have a birth name or legal passport. I picked up a used 9 millimeter from a firearm retailer owned and operated by former members of Da Lench Mob.

Psych, they were a bunch of libertarian cosmetologists who gave up on skin to start selling heat. We got along well enough for them to sell me a piece, then I darted out, looking for some kind of high-priced trouble.

Nah, people started looking for me. Seemed Cindy Brady had leaked my prescription status on a social media platform whose name ran away from home. All, "beggars can't be choosers," or whatever.

Strike that, I was listening to Smokey Robinson and the Miracles sing, "Choosey Beggar" in my Walkman when an up and comer on the block stepped to me with her people.

"Word is you've got something to take the edge off," she said.

Bonita didn't hesitate when it came to getting what she was after. She hated the manufactured Motown sound and the surrounding Hitsville, USA metropolitan area.

"You can get with this," I said, "or you can get with that." I pointed to a Paul Bunyanlooking motherfucker holding a melted ice cream cone. Dude was on some other, Neapolitan shit. Bonita coughed up a hairball and spat it out onto the freeway.

"How much do you want for the hooch?" she asked.

She was a spineheavy business woman. 
"\$500 a pill,” I said, “no questions asked."

I had arrived at the figure with help from a motivational speaker. Bonita balked.

"What's keeping me or one of my homegirls from copping a prescription of our own and hitting the pharmacy up ourselves?"

A coldhearted challenge.

I lifted my black umbrella and clicked it open to keep cool under the rain.

"Any of you and your homegirls got a brain map like this?" I pulled a psychiatric printout from my coat pocket and pointed to the discrepancies between the two hemispheres of the depicted gray matter. They were highlighted in blue ink and came with a convenient explanatory pamphlet. Bonita read the literature like a saint. When she finished she folded the pamphlet back up into triangles and handed it to me.

Her mouth was dry anyway.

"So," she started, "they only prescribe Chill to people that mindfucked?" She nodded her small head towards the printout I was holding again like a deck of cards.

“That's what the Doc tells me." I was the size of a brand-new wallet.

"I don't know many people that fucked up," she said.

"From where I'm standing," I said, coolly, "you only know one."

She considered the distance between us like a trivia question.

Finally, she said, "I'll take a hundred pills. If I can push them around in the next few days, I'll be back for another hundred."

I counted her cut out on the sidewalk with a symphony conductor's fine baton. One hundred to the letter, and I put a free sample on both of our tongues to toast a new business partnership. She swallowed it down with a sip of Diet Coke. 
Almost immediately, she was Tina Turner taking her past out on a punching bag in a daytime talk show green room. Her homegirls freaked and wondered about Bonita's blood toxicity levels relative to the width of her braids. I kept my own hair shaggy for a reason. The Chill took on more of a Hemingway after a celebratory toast kind of vibe. Nothing could get in the way of my high.

Bonita handed me the cash, and I took it to my breast like a newborn crackbaby. Like I was all it had to depend on and the reason behind its small, hopeless eyes. The money had fingers like ragweed. I started tearing up. Bonita sat down in the middle of the street and adopted a political lifestyle of nonviolence. Other hood bitches feared her newfound peace. Thought it might steady her shooting hand even more. Make it even worse a move to cross her on the block without the right backup firepower lip-gloss.

\section{Track 59}

Here and there, hoodlums started picking up Bonita's product. Before long, she came back wanting more stock in the heady business. I dished it out like canned fruit and collected her cash cold and solid. More than any rap star I ever saw flossin' up in Forbes magazine. I kept the dough in the beat up backpack I had walked with all the way through high school graduation. Next to a pre-calculus textbook shrink-wrapped direct from the publisher. Enough cash to choke on twice.

And the cats on the block Chilled bigger and badder than ever. Their ears on their shoulders cold as ice, too. Nothing could touch them in their sensitive inner parts. They'd have had to own skin first and the parts to begin with. The Chill put them out of the City's jurisdiction. Some extraterrestrial landmine shit. The whole neighborhood blew up easy. Hardly anyone noticed the drool and stutter lips. 
I put my earnings away for a graduate degree in pharmacology.

Nah, I bought as many flat screen TVs as I could find in electronics store sale advertisements. My apartment was televisions unpackaged and lined up like dominos to tip over all at once. There was no space to cook scrambled eggs or microwave frozen entrees, but I watched all of the televisions simultaneously instead. Each one on a different channel, and some of them on the same channel to show off.

There was no room for my father to perform his rehabilitative exercises. His clothes took on unhealthy shapes across his back. I bought the entire apartment building cash and had him move his few belongings to the roof. He was happier drenched, and I went up to visit him every night before bed. I didn't sleep because the SuperChill was sleep enough, but I kept up the appearance of a sleep schedule to have a reason to visit him and talk about approaching weather patterns.

No, we played card games he made up the rules to.

"I've been slipping 50-dollar bills in your pants pockets when you nod off during our games," I whispered. I could tell him anything in those days.

"I thought I had been gaining weight in the rear," he said, innocent.

"Nope, it was loot instead. You had no part in it."

"Whew," he sighed, relieved. "I thought it was all over for me and your mother, then. You know how she is about measuring up."

"Dad," I said, "Mom has been gone at least as long as we've known each other."

"No, no, no," he denied. "She's as present as Easter dinner. Legs for days."

I threw up over the side of the building that was mine with legal documents for proof. 
"When was the last time you saw her?" I asked. The walls of my mouth all acid and sunflower seeds.

"It was this morning when we made love to the mellow sounds of a box fan chopping up our voices."

I threw up into an empty can of Bush's baked beans.

"But what about all those stories you used to tell me about loving her so much she disappeared from all my childhood photographs?”

He nodded like a junior high school yearbook.

“Oh, those were just to keep you feeling grounded. Too many young men take their mothers for granted these days. It's not all French toast and summer bee hives, you know."

I could smell her bones in the family plot outside of town. The same from-scratch recipe. I ground up some SuperChill and mixed it into his Folgers coffee. He drank it like the a protein shake and started talking about professional baseball salaries reaching the tops of other buildings.

Strike that, we talked about plutocrats running everything north of the equator.

No, we talked about Tolstoy's religious conversion and its impact on the both of us.

"Now I can't get up when I fall," he reasoned. "Now I can't fight against the things doing the pushing over."

"But what if you tip by accident?" I asked.

It was a philosophical pop quiz. Pops took his time.

After a pause he said, solemn, "Fate is pushing it all," and, again, "Can't fight it." The Chill was having an effect I hadn't seen on younger dark-skinned men. My father was made out of tube socks they don't make anymore. Yellow rings around the upper calf. 
"Dad," I argued, "you can’t possibly pin all that high theory on Tolstoy."

He could barely read in the first place. Some other sons were nodding off with their fathers down on the streets. They were learning how to build campfires from newspaper kindling and lighter fluid. Tiger had his father upside down by the ankles and was tickling the bottom of his feet. I had never seen the two so much as stick their tongues out at each other before their eyes glazed over. The SuperChill was flashing its healing power, and we all had some sort of distance we wanted to forget.

My father finished his brew and babbled the secrets of his bad temper as he fell off to sleep. I propped his big work boots on a milk crate and turned the other cheek.

\section{Track 60}

I held the flier up and read the print cutouts through the rain. I thought to call it the "Do Work Manifesto" and have photocopies made at Kinko's. Instead I let the weight of the paper do the talking and fall apart in soggy clumps. The street signs taking over and directing the gutters where to go.

José Raúl Capablanca wandered over and asked what I was up to in the middle of the night.

"Hustlin,," I said, serious as ever.

“Looks like you're standing still," he poked. "Waitin' for all the right moves to come to you."

We bullshitted for a couple minutes about the upsides and downfalls of severe patience. I argued for the side of rolling over at the right moment to get out of bed. Capablanca called my position a loser's bet and argued for people getting advances on their paychecks and blowing the cash on the stock market and new blinds for their homes. 
“To keep muthafuckas from seein' what their eyes don't need to see, feel me?"

I was over the whole thing and told him so, my mind made up on a breakfast of champions. I looked around for the nearest convenience store that served whole milk. The neighborhood smelled like hand grenades, but I was salty below the eyes and melodramatic. Looking for the next big thing. Even if it was in the eyes of the Other man.

\section{Track 61}

Mona had herself over the living room couch, booty up in the air like a disco dancer. All sparkles and lace. Conga lines of SuperChill in the seams of the hardwood floor. Marching like soldiers up Mona's long nose. She asked me to call a handyman 'cause her nostrils were clogged and leaky.

"I'm not in the maintenance business," I said. I was coldhearted when I built model airplanes. The whole place fuming with craft glue.

Mona was watching reruns of The Ricki Lake Show on cable. Big wells of tears in her eyes over the lovely relationships falling apart in front of a live studio audience. I was picking fuzz from the welcome mat and grinding my toes into the floorboards.

"We need to make a pit stop at the Home Depot," I said, "to make sure the job gets done right." It was nonnegotiable.

Mona ignored the weekend warrior call and started flipping through my old junior high school yearbook. Our haircuts matched the season we were in then. No one knew anything about Posttraumatic Stress Disorder. It wasn't getting half the media attention it pulls now.

No, she was flipping through the classified ads like loose-leaf paper droppings. I smelled a rat. 
There were sturdy mousetraps lining the walls of each room in the cramped apartment. Traps on tops of others in suspected weak spots. Vulnerability beginning and ending in the places we most expected it.

"I'm way to busy to go home improvement shopping with you today, Mookie."

More nasal than anything. Whole pieces of cardboard jammed in her sinuses.

“Whatchu too busy doin' then?" I asked.

She gave me a cross-eyed guffaw.

"What does it look like I'm doin'?" she asked, annoyed. "I'm looking for all the right work."

Her wrists were covered in emergency room check-in bracelets and lesser jewelry made out of dull, colorful sugar candy. She started gnawing at the second ones. Little, shy nibbles at first to get them started. Before the lunatic chomping took over.

"How do you ever expect for us to make this house a home," my arms were wide open while I spun around showcasing the interior, "if you're not willing to lay some serious bricks?"

She looked at me like a can of tuna fish. Pinched her nose at the intimate smell.

"Mookie," she whined, her fingers crossed at the webbings, "I don't know if I'm ready for all this he-said/she-said bullshit, know what I'm sayin'?"

Houseflies swam in her eye shadow. She had gotten her bellybutton pierced since the last time I'd seen her. The tube top around her said it all, right at the ribcage.

"No," I whimpered out, on my hands and knees near the front door. "I don't think I know what you're sayin' at all."

She rolled her eyes and checked the hour on her digital watch.

Ricki! Ricki! Ricki! 
“Mookie, you know I've had nothing but love for you since we was little kids growin' up on the block together, right?"

I was breathing into a brown paper bag by now.

Ricki! Ricki! Ricki!

"But ever since you started slangin', I feel like we been goin' in two different directions." Ricki! Ricki! Ricki!

"Now, you have a very special place in my heart. And you always will, you know that?"

She pulled her tube top down and pointed to the faded heart tattooed over her left tittie with moxie written across it in pink. "Mookie" above the heart written in shaky cover-up handwriting.

"But I just don't feel like you appreciate me anymore," she said. "Like I don't mean nothin' compared to buyin' and choppin' and sellin'.”

My shoelaces were untied, and the pit stains showed. A crooked halo hung over my head from the antique coat rack Mona's grandmama had given us when we moved in together.

Ricki! Ricki! Ricki!

"Also," she chewed on her lower lip like it owned the place. Her eyes on the frayed sofa legs. "I've met somebody else ..."

Ricki! Ricki! Ricki!

Some hood nigga from the block busted in the front door with a big Timberland boot. Ricki! Ricki! Ricki!

"Say hello to America's worst nightmare, sucka!"

Dude looked like Orson Welles in burnt cork stage makeup. 
Check that, dude looked like Ida B. Wells, all unapologetic and jacked up on Barry Bonds juice. His big bald dome scraped the apartment ceiling like a security deposit. I brushed fallen ceramic dirt off my shoulder and flipped out.

"Who the fuck 'dis nigga, Mona!"

Ricki! Ricki! Ricki!

Mona twisted the tips of her weave in her fingers and played the fool.

"I don’t know, Mookie," she said, innocent. "He don’t look familiar to me.”

But the overgrown motherfucka whipped his belt off from around his waist, dropped his jeans and boxer shorts, and let his nasty thang have the floor.

“You know 'dis look familiar 'doh, don’t it, Mona?” He wiggled his hips around like Marky Mark, and Mona watched his funky thang stir the place up with a smile.

Ricki! Ricki! Ricki!

I uncrossed my legs and stood up like a zeitgeist. The apartment's insides spun and dipped from the rush of blood upstairs. I fell over dizzy and knocked my head on the end table. The TV remote fell off on impact and cranked the volume up astronomical.

"This otherworldly dick make even the fellas fall over amazed," dude yelled. "Who gon' stop me, huh?"

Mona was clapping her hands at his boogie and grinning. Ricki! Ricki! Ricki!

\section{Track 62}

Mona got her sorry self up off the couch and ran to Master Blaster's bulky frame. Shrunk into him with her headlight eyes. I wept hard the way someone might after losing something in a field of skittish flowers. I walked out the apartment door to let the love grow on without me. 
My father was sitting on the top step of the stairwell, filing his fingernails casually. A pair of Ping-Pong paddles in his back pocket like a bad joke.

"You win some and you lose some, sport."

His eyes were the same pair of glasses from my seventh birthday party. He tossed a reel of dental floss down the stairs to listen to it clack. I heard the same string music. It was the first experience we had shared together since the peace treaty.

"How ‘bout a Happy Meal, champ?" he asked. "It's on your old man."

I didn't have the guts to argue, and I was hungry for a high quality toy. He took my hand like never, and we walked out the building and onto the block. A station wagon full of teenagers sped past and called us a lousy pair of lover boys, and we talked about the weather to ease the awkward silence in between.

"In my fifty years living in this town," he said, "I have never seen so much rain all at once. And for so long."

“How many days in a row has it been now?" I asked.

" 21 , if you can believe it, son."

"I guess we have to believe it with our own eyes."

"Not to mention our own Laundromat quarters, am I right?"

We both had loose change in the polo pockets of our V-neck t-shirts.

"Dad?" My voice broke in half.

"Yes, son?" he said. We stayed hand in hand.

"Have you ever had your heart broken on air?" 
His steps were long and confident on the sidewalk. Enough for women to stop and take notice, assuming he owned his own chain of carwashes or was running for public office. Their eyelashes listened exclusively to Prince and the Revolution on vinyl.

"I'm going to tell you a little story, son," he said. His face was pockmarked and beautiful. “A story I've never told anyone else before."

I took faster, shorter steps to keep up with him. My ears grew steady and pink in the rain. He cleared his big throat with a smoker's cough.

"When I was about your age," he reminisced, cool, "I fell for a pretty little number by the name of Foxy Brown. Ever heard of her?"

I blushed. "Can’t say that I have, pop."

He went on. "Well, in those days she was the genuine article, fair trade or not, niggas was dyin' to get their hands on her."

"Was she the most beautiful belle at the ball?" I asked.

He laughed. "She was the hottest lil' thang in the club, son. And where I grew up, they didn't let little black boys go into the white clubs unless they were handboys to one of the hotshot white businessmen who ran the town standing on their tophats."

Two or three little girls passed us by eating ice cream cones with hair barrettes.

"Now, me and my boys heard around the way that Foxy Brown would be performing at The Hot Spot some Saturday evening after we had finished our homework. Of course, we knew that The Hot Spot was a white club with this big ol' bouncer named Conway Twitty who stood guard at the front door with his big bad self and a pirate patch over his left eye. Even kept a paring knife in his teeth like a real swashbuckler." 
We laughed a little bit together, and I wiped the leftover rain from Mona out of my eyes. There was no such thing as golden arches anywhere in the 'hood. We were walking in full circles, headed nowhere.

"So we all put our heads together and tried to think of a way to get past the muscle and into the club in time to see Foxy perform." He was bulky and clean. "Well, it didn't take long for us to figure out that some Tom Cruise-style Mission Impossible covert breaking and entering operation was a no-go. We simply didn't have the schematics. But what we did have was a City College summer arts camp introduction to acting and improvisational comedy. So it was your old man here who came up with the idea to try and get hired as handboys to the white men for the night. All we'd have to do is pose as clean-nosed colored boys with our eyes on the prize and our backs set to labor. How hard could it be to fetch champagne refills and shine shoes for a night if it meant seeing our dream girl perform live, up close and personal?"

"So what did you do, pop?"

"Well, I'll tell you what we did, son," he said. "We ran home and grabbed our fathers' three-dollar suits from their closets and put them on ourselves. Sure, they were long in the legs and sleeves, but we made 'em look as sharp as we could. Even picked carnations from our mothers' gardens and stuck them through our lapels with safety pins. Then we walked all bad and funky to The Hot Spot to wait outside for the white people to show up in their stretch limousines.

"And show up they did. All coattails and fox pelt scarves draped over their rattling ivory bones. Me and my boys brushed our teeth with spit and our pointer fingers and tried our best to look presentable. Most of the white men and women had handboys already with them, opening 
the limo doors to let them right out at the nightclub's red carpet entrance. But some folks didn't, all alone, and we smiled and flexed our small muscles under our fathers' suits.”

“Did anyone pick you all up and hire you on?” I asked, excited and nervous.

I had never heard my father story tell before. The moment took over to a place where I loved him like a comic book villain.

"Well," he said, "to tell ya the truth, the other boys weren't so lucky that night. But a bushy Australian man carrying a briefcase full of foreclosure documents hopped out of his whip looking for help and spotted me standing patient and professional on the curb.

'You there, lil' hip cat,' he hollered at me.

'Me, sir?” I says.

'Yes, you. I need a handboy like now. You interested in earning an easy fiver?'

"I got hold of myself and hustled over to him, and after exchanging pleasantries and business cards, we hooked arms and walked past Conway Twitty right into The Hot Spot.”

“And did you see Foxy Brown?” I was geekin’ out.

He shook his big head. 'It wasn't that easy, son. First, I had to spit shine my client's shoes and brush them with a hair comb. Then, I had to lint roll the back of his suit and renounce any ties to the Black Panther Party. Then, I had to tweeze the shrewd red hairs between his eyebrows to make sure he was looking right on."

“Then did you see Foxy Brown?" I asked, out of breath from walking and the rain.

"Yes," he said, reminiscin'. "There she was, up on stage with nothing on but a case of Sprite cans shredded into a sharp bikini ensemble. Light hit the aluminum here and there, and her skin took on an oil spill. The blackest, most beautiful mess of woman I ever seen." 
His eyes went somewhere above the neighborhood and got torn apart by the blades of the police helicopter patrolling its beat. His hand loosened around mine. People were staring from their front porches and throwing bibles at us. No one recognized my father from before his long vacation trip to Riker's Island Resort and Conference Center. His sweet breath still smelled like blueberry muffins and pillow mints.

Hoopties cruised up and down the block, some slowing and letting their engines run when they got near us, walking. My father didn't break his tone for nothing and nobody, acting like it would take away from his being The Man.

"Foxy never looked so fine. She did her thang up on stage while the white men in the audience snapped their fingers and the white women wanted out. I waited on the man down under like he was on top of the continent. No request went unserved. And it was all worth it. You know why, son?"

"Why, pop?"

He wet his lips. "Because while I was picking cabbage out of that cracker's back teeth, loosening his tuxedo suspenders in the men's room, calling his girlfriend international long distance, buffing the dandruff patches off his bald head, and cutting his minute steak into individual bites, I was listening to a ghetto angel sing her heart out and shake that ass like the whole world was watching. And do you know what I learned while watching her perform?" "What's that, pop?" I asked, anxious. Like the answer had our lineage on the line. Just then, a black junker with a blown-out back tire screeched over to us with the windows rolled down into the doors. The driver was a Cuban cigar with thick eyebrows and a knife scar across his throat.

"You the whiteboy muthafucka slangin' all that Chill?" he shouted. 
I felt like Destiny's Child in the spotlight. The cabbie took my scared silence as the wrong answer.

“King Cobra don't like competitors stealing business from him. Consider this your first and last eviction notice."

One of his homeboys in the backseat stuck a silver pistol out the rear window and started blasting hellfire our way. My father pushed my body and me out of the line of fire, but a bullet clipped my ear and dug into the warehouse wall behind. The Cuban's hoopty tires took off into a solo and squealed away, the back license plate reading "SNAKEBITE" and covered in splattered mud.

“Pop,” I gasped, “you saved my life you gave me." I was shaken and rolled out on the sidewalk. He was lying next to me like a campsite. I got to my feet and brushed gravel from the knees of my blue jeans. I bent over to offer the caped crusader a hand.

“I mean,” I corrected, cool, “good lookin', homie. I don’t know what those muhfuckas had in mind, but ... Dad?"

He didn't reach for my hand or move. His body lay crooked on the ground, soaking up the rain. I nudged him with my fingers, shook his top shoulder like in the movies. Blood started to run towards the street.

I rolled him on his back and found all the bullets firm through his chest. Expression like a Polaroid camera. Eyes way up to the police helicopter again, only this time it eyed him back with its cold, white look. The spotlight shone on and on, riddled us silly while I begged him to answer me. 


\section{Track 63}

The grocery store on the corner was owned by a first generation Shaolin immigrant named Mr. Woo with a spaghetti moustache. His apron covered in butcher blood ran the store while he was away on business or visiting his invalid parents on the Coast.

The moon had a way of poking you in the lonely eye.

Nothing tasted in my mouth.

Unfamiliar air on the block.

I walked to Mr. Woo's to check the produce section for a variety of blackberry some cat told me cured the Mississippi Delta blues. The grocery's doors were locked in front of an "Out of Business" sign on a scrap of cardboard. The lights hanging over the aisles were dead to the world. No sense in arguing with them. I thought to walk home and tell my widow mother to get her finest black dress dry-cleaned, complete with the lacy mourning veil. Even the ice cream truck circling the 'hood called it quits and wrenched its own tires off. Left them in the middle of the road as a resignation hazard.

But there was a flicker of firelight down the pet supply aisle when I looked harder and pressed my eyes to the front door's glass. Something like a nightlight hiding under a bushel.

Scratch that, it was a candle in a candlestick burning weakly by the Purina One puppy chow. The econo-sized bags meant for breeds weighing between 25-30 kilograms flat. I did the math in my head. Price per unit to kilo of body weight.

None of the numbers added up.

The firelight flickered off black skin faces in the aisle, though. Moving around the candle in slow circles. Lipstick across the cheeks picked up in the light. I snorted a line of SuperChill off my index finger and waited for it to sink in. The effects were miracle-fast. I regretted being 
born and orphaned and never knowing the queasy joys of a father-son canoeing trip to the Grand Canyon. I wondered what my mother would have thought of me if she'd survived the delivery. If the embryo would've implanted like the specialist promised it would. It wouldn't have mattered that she never graduated high school. From the type of family she came from, no one would've expected anything too much.

At least four people circled themselves around the candle in the middle of aisle 13. I thought to go in and join them. My own lipstick in the front pocket of my blue jeans. A purplish shade my mother used to wear to fancy PTA affairs. My father treated her like an expensive prostitute. All while she was doing award-nominated voiceover work for PBS after school specials. The ones featuring unlicensed Madonna material. I knocked politely on the door to see if they would hear and let me in.

They didn't hear.

I wrapped my arms around myself to keep out the chills. Knocked again with Southern vigor. They kept to their dancing accompanied by intentional hums.

\section{Track 64}

The front door was unlocked, and I scampered inside unnoticed. No security guards were working with flashlights. Cereal boxes were stacked in reasonable pyramids for display and consumption. A smell of rotten avocado and Arm \& Hammer baking soda. Mopheads and dustbins interacting with each other. Four moaning voices speaking a language.

I walked cautiously to where I had seen them from the outside. Through the glass and green sale stickers. The floor was freshly waxed and warm to the touch (I had kissed Mr. Woo's daughter at a boy-girl party once. She had the eyes of an elegant cipher. We were meant to be. 
She was forced to wax the floors on her hands and knees because there were no electrical outlets in the store. Her father believed in strict manual self-control and work ethic).

Shirley Woo had gotten knocked up in high school and waxed the floor of her father's grocery store with her distended belly. Until she came full term and after she was placed on mandatory bed rest. A dry washcloth tucked in her maternity pants.

The moaning stopped from the pet aisle. No one really cared when I showed up in my loose high-top Nike sneakers. They didn't even notice them or that I'd powdered my nose to look poised and fancy. The four sat in the aisle holding hands and praying for the lost and sick.

"What if He never answers?" I asked.

The voice I made was outside my own head. I reached out my hand to grab it and pull it back in, put it inside from my ear. But it was loose and running wild like a frenzied brat.

"Our God always answers," they said in unison.

Check that, it was only one man's voice. But it had four distinct sounds, each one stimulating a different region of the ear canal. I stuck my pinkies in deep to clean them out. No use.

"How do the answers come," I prodded, "via email?" I looked around for a desktop computer, but it was too dark to see anything worth it. The Macintosh Company was rumored to be opening a manufacturing plant around the corner. Most of the gossip was made up by industry insiders in an effort to sell more tech magazines. But I was still looking forward to filling out a long job application form. My driver's license number memorized and filed away for safekeeping.

"No, that's stupid sounding," he said.

The leader looked like a stupid son of a bitch himself. 
"Do you have any idea how stupid you sound to us right now?" he asked, pointedly.

He stood up and had "Bruno" tattooed down his right forearm. I got defensive.

"No stupider than four lazy motherfuckers holdin' hands and chantin' to the ceiling third shift in a five-and-dime."

I started dancing like James Brown live at the Apollo Theater. My legs weren't as weak as I remembered them being. I didn't go to hell in a hand basket. My mother had lied to me about black choreographers.

"We know the Way of the Dragon," they said in unison.

No, the leader was the only one allowed to speak without threat of physical punishment.

"And we're a registered tax-exempt nonprofit organization to boot."

"What do you do?" I asked.

"We aid in the spiritual uplifting of depressed, grieving, and marginalized people."

"My father just died in a drive-by shooting."

"We know, we saw it through the glass."

“Why didn’t you do anything to help him?” I asked.

Bruno looked hurt. "Why do you think we're praying in a small circle?"

I was over the moon at the fervor of their intercession and felt a part of the growing fold. I asked to join the prayer circle and found an available seat.

"All who are humble in spirit are welcome to join in our worship."

The leader called himself former Vancouver Grizzly power forward Shareef AbdurRaheem. I knew him from my extended affair with Kobe Bryant in NBA Courtside. Pretty good range for a big man. 
I considered lifting all the Kool cigarettes from behind the checkout counter when I eventually left. Elevator music played in the store 24/7. Lots of Allman Brothers Band and Johnny Depp movie soundtracks. I could pack an amount of Chill into the tips of the cigarettes and sell them for a hundred bucks apiece. I could call them "Cool Runnings" starring the late John Candy.

"We sense you have an impure heart, brother."

Shareef looked paranoid. He spoke from his sharp goatee. Got to the point.

"Do you struggle with addiction to the material world?" he asked.

My pockets were stuffed with feather pillows.

"Nah," I said. "I'm on the straight and narrow path."

They bought it like a fresh dessert, sticky fingers through their short, greasy hair.

"Do you struggle with matters of religious intolerance?"

This one came stern and nasty.

"Nah," I lied. "It's all One Love to me."

But when they called my bluff and pulled out a boombox to listen to Nas's Illmatic on CD, I reached for my gun. Shareef noticed and played tough D. Palms out front and knees bent deep. Ready to block a shot.

"Don't start nothin'," he said, "and there won't be nothin'."

I didn't believe him. My years were stored away in mason jars in my paternal grandmother's cellar. She was a child of the Depression and taught me to cry first, shoot second, and ask questions after the daytime courtroom TV shows were over and done with.

My shoelaces were untied, and everybody knew it. I always had trouble with the getaway. 
"Why do you bring thoughts of violence into our congregation?" Shareef asked, inconsolable.

I took my hand off my gat in nonviolent protest.

"No, no, no," I hurried. "I don’t want there to be nothin'."

“Then there won't be nothin'!"

He shouted angry tears like I was his baby mama. We tried to start things back at one, Brian McKnight reunion ballads taking over the supermarket soundtrack.

"Listen, my man," I said, "I feel like we got things off on all the wrong feet."

His people danced around the candle while it melted. Funky moves that tested their abdominal fitness. I could see the focus and strain on their dark faces.

Shareef was a man of his word. The honorable way he kept his back uncomfortably straight and sound. I misremembered how my father had taught him how to be a man instead of me. In my place. How when we were kids he would run over to our apartment building barefoot and pick garbage up with his toes. Folks around the way started calling him lil' Pickup, and he liked it best.

I looked down at Shareef's toes, and they were the same ones I misremembered. But he didn't recognize me on account of the turf war years. I didn't think I had changed so much since becoming a man.

Psych, I had never seen the cleric before and called him a derogatory name relating to his headdress. I used everything my father had taught me about foreigners not knowing how to get gone.

The figures stopped dancing when I went off. It was a silver tirade worthy of a nightly news special. 
Only Shareef hadn't even heard what I'd said because his face was in a deep, otherworldly meditation. The rest of his body there with us by the dog collars, but his face with my father in the afterlife. He was whispering something holy to himself.

"And on the way down," he chanted, "you saw me, and you saved me from myself. And I won't forget the way you loved me."

His hair stood on its tiptoes. Out of this world.

"Hey, man," I offered, hesitant, nervous to mess with his Zen. "You know if there's a John in this place? I can't hold everything in forever. I'm not the Dali Lama."

Shareef didn't twitch an eyebrow. His people were on it, though, pointing to the back corner of the store by the bin of limes next to the import beers. I showed my gratitude by pulling out my piece and blowing the clergy away. Into eternal damnation, where there will be weeping and gnashing of teeth. They didn't have a last chance to repent to Jesus or an acceptable equivalent.

Scratch that, instead of shooting I thanked them for their assistance with a bow of my small head. My glasses fell off, and the prescription lenses popped out when they hit the floor. I wandered towards the facilities woozy as a fire ant. My bladder burnin' somethin' fierce.

A crooked cop blocked my access to the can with his riot gear. He stuck his big plastic shield into my chest and chucked a canister of tear gas at my eyes preemptively. I didn't see it comin' and blinked out of habit. The can bounced off my eyelids and clacked to the floor with my glasses there already.

It wasn't a good day to start a brawl on his beat.

I remembered my high school history textbook's chapter on the Boston Tea Party. I had a slice of lemon stuck in my own front teeth. The gat itched at my waist. I went to scratch it and 
found it wasn't there at all. It had been replaced by a large superficial rash shaped like the Continent. The copper saw the abrasion and let me pass on principle. Out of disgust and racism. His whole look pitiful. Like it had never left home.

But I appreciated the nod to his awareness of skin at all. Most people I knew at the time didn't bother to bring it up or think about the implications of owning dermis and operating within its limitations. I thought to wash the wound out with dish soap when I got to the nearest drain.

\section{Track 65}

The men's room stalls were covered in cut-out photos from Time magazine. Most of them related to the Kennedy assassination. Some, scattered here and there by the broken hinges of the stall doors, memorialized the unsolved murders of Tupac Shakur and Christopher "Notorious B.I.G.” Wallace. Print versus digital beefs that had caused bad blood between the East and West coasts. I opened up the first stall door, and there wasn't a single dirty toilet. I curled up on the cold floor and slept for like a week.

The dreams I had were of my time in the South Central P.O.W. camp.

No, I dreamt of playing shoot 'em up videogames with Roscoe. Taking his money and putting it in a plastic sandwich bag. His whole bald head full of ideas like growing up to be successful men. Just a hint of faded hair sprouting from his bottom lip. His mother with the unsupported tits of a welfare princess hanging from her front.

No, I dreamt of my own mother sitting on a park bench with strangers taking her photograph. She didn't stop to ask them their intentions and found herself on the cover of every gossip magazine in the country. How she should know better than to neglect her children with an afternoon away from home. In the photo she was reading a collection of Sylvia Plath poems a 
reliable source had told her were sentimental garbage. She had trusted him with all the hairs on her body.

Tears came from her onto the poems. She started talking to herself in broken English.

"This one goes out to all the lovers in the world who still don't have it in 'em to take a hard look at the crystal ball."

"No, this album is dedicated to all the teachers that told me I'd never amount to nothin'."

"No, this is for the hairdressers who didn't have the strength to pull a hot comb through my scalp. This is for the birds and the bees congregating around the 'Colored Only' water fountain. I love the way y'all buzz about. My whole voice is yours."

She slipped a bookmark in between the Plath collection's title page and table of contents in disgust. Not really diggin' the whole, "white girl pain" thang. Her business all public intellectual and giving back to the community at large instead.

She found a stick with a record needle pointing out the end of it and walked around the park stabbing bits of garbage and picking them off into a brown paper bag. A white cop noticed her from his cruiser and tipped his cap in appreciation. The mayor was sitting on a thrown near a national landmark, receiving his daily pedicure; he nodded and smiled like a milkmaid. Kids ran around barefoot themselves, screaming offensive things into their walkie-talkies. No one suspected them of foul play.

All the birds had died of heat stroke the summer before. Folks called it the night the lights went out in Georgia. They remembered it fondly over scratch biscuits and sweet blackberry preserves the color of Harlem Renaissance man Wallace Thurman.

Rewind that back, I dreamed the way it feels to walk across a bootleg stage and get handed a high school diploma. Niggas in the rafters hollerin' and screeching off air horns till the 
principal gets all red-faced and refuses to say another ghetto name until the ruckus stops. His tie in a twisted knot, keeping his blood pressure barely under control.

I had my own calming medications in the palm of my hand while I walked lockstep. The fat fuck of a P.O. playing his Nintendo Gameboy in the front row of the audience. The time we'd spent twiddling our thumbs. He would never know how miniscule it all meant to me. The guidance and mentorship out of this world. Alien. Intergalactic planetary. Taxpayer sabotage.

I clocked my feet with a radar gun going 15 miles an hour in a school zone. A felony offense for a minor. The principal commenced to handing out degrees at a fever pitch. Not looking any of the graduates in the eye.

I fell apart unbelieving, like I'd made it against all odds.

Textbook dust jackets in my bedroom covered in SuperChill residue. Prescription pads like CliffsNotes. Knockoff Nike kicks in my desk drawer instead of White Out.

Nah, I dreamed up a white man with a gray beard piecing together model boats inside the bellies of wine bottles. Dude was up to his ears in tweezers and lengths of fishing line. I barely recognized him as the family breadwinner. He was wearing a Phoenix Suns basketball jersey of Charles Barkley. Had lips just the same. The same know-it-all from way downtown moustache. He had the name Herbie Hancock, and his maiden voyage was going under. So he played local piano bars on the side to keep food on the dinner table. Beans and weenies like clockwork. His wife, Naima, used to beat him to death with her stamp collection price guides when he got out of line.

Real talk, I dreamed the way I felt after waking up. Wanting to go back to where I was before. I kept myself in quilts from the antebellum era. Everything came in fits. My mind was loud with its own radio-tuning knob. I tuned in to local sports coverage or another race war 
correspondent covered in blood. His reports bubbled over hot and vulgar. I kept my own political leanings on the hush.

\section{Track 66}

"Kid, you gotta wake up." The riot cop's voice was a boot in the ribs from the next stall over.

"What time is it?" I asked.

"Time for you to get to gettin' is all. You don't have to go home ..." His voice trailed off into the sewer behind his warm piss.

I asked him for a coloring book to calculate my losses in crayon, but he balked. I asked for a desktop tearaway calendar, and he pushed two or three under the stall partition with the toe of his jackboot. It was the nicest thing anyone had ever done for me and lived to tell about.

It was still July.

I had an unclassified amount of SuperChill in each pocket and bills to pay. My eye spotted a 50-karat Jesus piece featured on the cover of a JCPenney catalog stashed underneath the toilet paper dispenser. The Christ figure frozen in white got to me. I wanted a taste of that old-time religion.

My stomach was emptier than sin. It felt familiar. I remembered growing up with my father and mother. How Baby Brother would kick and scream until I held him to my breast and let him suck nothing out of my dry nipple, until he fell asleep.

Psych, I remembered the cold bed of an only child. Sun falling dead on the roof of the orphanage. The clattering of cats getting' shot full of holes over some dumbass gangsta shit. 


\section{Track 67}

Hog fell over bleeding from his head in the front yard.

No, it was outside the Bronx River Community Center. I ran to him on my small legs and asked if he had finally defeated Captain Planet.

"Check this," he mumbled, and dumped a bottle of Drain-O onto the sidewalk. Nothing catastrophic really happened, but I gave him a last thumbs up out of pity. His eyes were the kind of glossed marbles a poor kid would want.

I ran home to tell my mother about the violence. Neighborhood kids were picking through each other's hair for afternoon snacks. I didn't recognize any of their greedy mouths. Mama sat on the front porch painting her fingernails Revlon pink. The color had been discontinued after too many black women wore it and scowled at middle management. She was the baddest $\mathrm{B}$ on the block.

"Mama," I shouted, out of breath. "Hog died over by the Center. Wanna go poke around for evidence?"

She didn't hear me over her Luther Vandross cassette tape, so I bent down and started massaging her feet. It was that time of the month, and her toes were dried up and pale. I jerked each one at the joint to snap some life back into them.

"Who the hell are you, lil' nigga?" she asked.

The woman wasn't my mother anymore. I had wandered into the wrong 'hood runnin' scared from Hog's corpse. His hairline the crest of the Red Sea. I crossed over it and felt like Moses Malone. The scared plump woman yanked her feet away and started screaming for her 
husband and his holy shotgun. I pulled my own kiddie piece from the waist of my basketball shorts and got ready to throw down.

When old Ward Cleaver appeared in the front door, I squeezed my trigger finger till it ran out. Mama screamed like a goldfinch and started pushing emergency numbers into her cell phone. It felt like a setup.

\section{Track 68}

I snapped back to reality.

Back to the grocery bathroom floor where my finances had been calculated by hand on the backs of the calendar sheets.

One big sale would do the trick. My next psychiatric follow-up session was a week out, and I needed the Jesus piece to keep the block lit up. The Chill felt like a medicine ball weighing me down. I twisted it around my waist and forgot about my childhood. I was a no-show in the delivery room and out sick on the first day of kindergarten.

The cop was washing his hands with Dial soap at the bathroom sink. He had that unclean look in his eye. I thought to ask him for a paternity test but got tongue-tied over the insurmountable debt that had grown while I was asleep. I owed Code-X more in consultation fees than the bank note on the house my mama raised me in. I tried to humble myself in the eyes of the LORD.

It came to pushin' and shovin'.

I thought to take out a second mortgage on the childhood home, but it was already subsidized from the get-go by the U.S. Government. The Rocky theme song played on repeat in my sick head with Curtis Mayfield singing "Pusherman" spliced in out of key. I thought what it would look like to be made out of repossessed paper. 


\section{Track 69}

Chelsea got her big teeth kicked in when her Daddy caught her pushin' dope. Dude was the Governor of Arkansas or something and had a serious a bone to pick. I met the High and Mighty Man out back behind a barbecue rib joint known citywide for its rub.

"I come in the name of the people of the great state of Arkansas."

His tongue was on fire from the marinade. I tossed handfuls of baking soda at his mouth to drown out the inferno.

“What can I do for you, Mr. Governor?” I asked.

His eyes were pickle relish, and his belly propped up a necktie with a Wal-Mart pin stuck through its heart. He hadn't licked his fingers clean. I didn't trust him for much.

"Been a lot of stress down in Little Rock these past few months," he said.

I had never heard of the place. My mind was on my money-money was on my mind, heavy.

"Sometimes the masses pack a lotta heat," I said. Like I had heard it in a gangster movie starring Wesley Snipes. Black as a cockroach in the dark.

"You may not've met me before," he hesitated, "but we have a lot of the same friends." "Name one person we know in common," I said, "and I'll believe you like a father figure."

"Does the name," he paused and lowered his voice to an eager whisper, "Code-X, mean, uh, anything to you?"

His hunched shoulders grinned and rocked. Night sweat wiped itself off his brow with a handkerchief. 
"Doesn't he own the grocery store downtown?" I asked absentmindedly, trying to change the subject. The Governor busted out laughing.

“Oh, no, no, no, my boy." He hacked up nervous phlegm while he snickered and spit it out on the ground we shared between us. What was his was his, and mine was mine. We covered our hearts with our hands like coldblooded Americans. My dick stiffened only a little. I saw his own crotch bulge a little under his slacks. We stuck our chests out into the street.

"Why he's the man with the plan who's all you can stand." The Governor said other mumbling things and shook his shoulders more like a big-time dancer. We might as well have been in a silent movie with the theater packed stupid.

“I can’t say I know what's on your mind, Jack," I said.

It was during a time when I didn't take kindly to being confused. The sun wasn't even up yet, and we were up to our ankles in oil-slick puddles. Someone in the distance was directing a Michelin tire commercial. A mess of cops were eating coffee cake on the corner of the block. Posted up until we thought to pay them hush money or somethin'.

"Listen, kiddo," the Governor's eyes met mine and got serious, "a little blackbird told me you seek therapeutic counsel once a month from a Franciscan monk named Code-X."

I couldn't deny it with SuperChill spilling out my front pockets.

My face flushed a virgin soil shade I had only read about in Toni Morrison novels. I thought of Doc in short shorts, riding a thoroughbred between his beefy thighs. Sweat dripping from his beard to the horse's mane extensions flying fabulous. I smiled like a stick-up kid.

Mr. Big Shot noticed the recognition and lunged at it.

"So you do know him?" 
He licked the barbecue grease from his lips and snorted. I had never seen a white man so connected.

"I see him now and then," I lied. "In between reruns of Growing Pains." The show helped me pull out my baby teeth. I kept glasses of skim milk on top of the cable box, just in case.

"Well, he and I used to be very close," The Man said. His elbow veins bulged under the streetlight. "That is, until he retracted his campaign donation and started courting a New Deal democrat with public speaking phobias." His knuckles balled into a white fist. I smelled Betty Crocker cookies baking from a project kitchen.

"I don't see what the health records of your candidacy have to do with me," I teased.

"It's not so much you, kiddo," he buffed his big class ring on his dress shirt cuffs, "as your prescription number identity down at the pharmacy."

The morning fog cleared out from under the steady rain.

“So ... you want some Chill?" I offered.

"Desire," he stammered, shaky, "is for perverts."

I knew he had murdered my parents the day after I was baptized. His teeth stayed covered in blood.

Nah, he had no information regarding the living arrangements of my foster parents but would have his secretary look into it on Monday. He was a junky of the people. For the people.

"How much you need, then?" I was tired of the same ol' hand-to-hand transactions. I was looking for new, high-speed excitement. Something that would blow my hair back and make me feel like New York's finest. 
The Governor calculated daily ratios on his Blackberry. I chuckled under my breath at the cut of his suit. Technology wasn't anything bigger than the way a man carried himself in public. He picked a number out of a hat like the Powerball lottery.

"I'll need a quarter-pound, easy."

"You in luck," I said.

I started scooping Chill into his open mouth with a rusty silver spoon I had found in a dumpster behind a Little Debbie cupcake factory. I measured the goods out in even, leveled-off doses until his eyes rolled back.

Nah, instead, he had me shovel the stash into the front of his flannel boxer shorts. The cops on the corner saw with their eyes closed and turned even farther away. We felt like made men in Little Italy.

Familiar constellations leftover from the night before marked the end of the deal. I looked overhead and saw a Mercedes-Benz logo hovering in the sky like makeup remover, waiting patiently to undo it all.

"You don't know how much I appreciate your generosity," he said. His voice was Elvis Costello singing a song I didn't like.

"How "bout you show me then?"

I held out my empty palm and treated him like a vending machine. His vest was lined with Twix candy bars. Cornbread stuffed in his armpits. He reached for the bankroll swollen inside his left cheek. The cash came out sour. He counted off stale hundreds until my nose loved the way numbers came off his breath.

My wrist weakened from the weight of the score. The cops had eaten an entire box of factory tour samples and were unwrapping another. Their fingers dug into the gooey vanilla 
cream filling like earthworms. The Governor ran out of dough at just the right time. City lawn mowing men pulled rip cords on their chopper engines and got to trimming the executive branches' unyielding hedges. I thought to invest in infrastructure for the working man.

When the gubernatorial motorcade finally pulled away from the pit BBQ joint I huffed the exhaust to get even higher up. Pulled out a memo pad and jotted life lessons to myself, for later, if the rain kept up:

1. Fortune favors the fat cats.

2. Never look a gift horse that way.

3. Trust the saxophone squeal like prime time.

4. Always lay low, until the snakes eat their own tails.

\section{Track 70}

The whole neighborhood had gathered into a bloodthirsty cipher. Cats I had known since the salad days were sweating from their temples, the peaks of their chests, dying to see me get what I deserved.

"Bury that muthafucka!"

"Send the IRS to collect, tax bitch ass!"

"Throw 'im to da streetwolves and see if he comes back!"

"Beat his mother over your bare leg until his whole birth is undone!"

"Circumcise the dick off his father to keep the seed from sprouting!"

"Cut coupons from the weekend ads to try and save his lousy soul."

Motherfuckers turned to loitering, shameless, not at all concerned with what the white folks in the cheap seats thought of us. My knuckles were calloused over from walking on my hands and writing blank checks. I was going broke. Lex Luther had his sights on my main bitch. 
Jesus Christ hanging around my neck in ice cubes. My nipples hardened tight from the freeze. The Lord and Savior purple as Hamburglar navigating a Play Place. Salvation secured in getting away with all the loot. Marlboro menthols lit up like crop circles, with no signs of intelligent life. This was man's work.

Jethro and Loosey were in my corner, rubbing my cheeks thick with Vaseline. Soursmelling and firm to the touch. Tiger prowled around running crowd control. Niggas with their pit bulls on leashes of electrified fence to show how hot they could shine. Tryna' act hard and not punk out from the voltage. Hoodrats in their finest sweatpants showing how low they could drop it. The whole thing like Dave Chappelle's Block Party with twice the rain and blood promises. My parents were at home knockin' boots.

Psych, they hadn't looked at each other in months. They hadn't talked love to each other since ten years before I was born.

Lex flexed the muscles under his t-shirt and looked flyer than Jean Claude Van Damme in Bloodsport. Ready to take my throat out if I got in the way of him gettin' his.

"What's the stakes here?" someone asked.

"10 to 1 on the whiteboy."

"Which one's the whiteboy?"

“That nigga you don't wanna try your luck wit' or fuck wit'."

People put up their rent checks as hot bets, fronted food stamps as collateral. I pissed my pants once or twice to get the nerves out. All the Shaolin monks gathered in the front rows and began moaning their meditations for peace. Folks weren't havin' it.

“Tell those bald muhfuckas to shut they sissy asses up fo' I give 'em somethin' to pray about.” 
"Look at the lovebugs lamenting the death of John Lennon and Yoko Ono's mattress."

"They musta died and reincarnated back to Nirvana's In Utero."

The crowd moved in tighter, and I couldn't breathe from the squeeze. Jethro got a gob of Vicks Vaporub and smeared it up and down my sternum clockwise. I was ready to tackle a snowman. Cracker Jack venders tossed their goods around but kept the prizes for themselves. Grandmaster Flash was on the one's and two's on top of a McDonald's on the block. He kept his records stashed in a milk crate under one of the golden arches.

Scratch that, it was Mr. Steve Hightower, the Booker T. Washington lookin' vice principal on the wheels of steel. His equipment set up on a lemonade stand we had taken over from petite little black girls just trying to make the best out of a bad situation.

The fear of the fight got my dick hard. I cracked the joints of the fingers in the other hand. Jumped up and down like a firecracker the day after the Fourth. Nothing but timeless potential.

Lex hadn't opened his eyes since he showed up. Or we couldn't tell from behind his Blue Blocker shades. Kool Moe Dee was hypnotizing women with his gold timepiece. Established matriarchs were passing out informational brochures for historically black colleges. Everyone wanted affirmative action like now.

Tiger's eyes got bigger than his stash box. Even with the fragile keys swinging around his index finger like the Sheriff of Nottingham. He was fixin' to rob from the poor and keep for the poorest of us.

"Not shit gon' happen between these two wild niggas till I see fiteen dollas from every muthafucka here."

People got their money up quick. 
Tatyana Ali, cousin of the Fresh Prince, got in the ring with a white bikini and a round number card. She meant to shake it until her rich mother knew the truth. We all wanted a piece of that.

Lex's skinhead caught the attention of a gang of neo-Nazis in the crowd. All of them had wild intentions and their hands over their stiff hearts. They wanted to see their boy skin me alive and wear the outer parts like a parka. For when the rain got wicked into sleet. I was afraid to stop their chanting. Nothing worse than chopping down a charismatic leader with a battle-ax. Some frat boys from Northwestern University had pushed a big screen TV to the lawn of their chapter house and were watching Mel Gibson in Braveheart on DVD. Covering their faces during the motivational horseback speech to hide the tears of follow the leader. Getting all nationalistic over their drunk Scottish grandfathers kicking in cash for their upcoming graduation ceremonies.

I didn't know who to hate more-myself, or everyone looking at me with blood in their eyes. "Iron" Mike Tyson stepped in the ring to referee the bout professionally. He called Lex and me to the middle for opening instructions. I caught my reflection in his gold front teeth. Wrinkles had broken out over my eyebrows, a classic sign of distress. Mike sensed it and forced us to touch gloves and return to our respective corners.

The whole Def Jam media circus were cracking beers open with their fingernails and tipping them out for fallen rap stars me and my white friends had never heard of. Jethro didn't even try to hide his confusion. His hands kept patting my backside like I was going off to college. My trunks were unprofessionally hemmed off. I thought of my mother's shaky needle hand. Her bifocal eyeglasses by the log cabin firelight. All Laura Ingalls Wilder with none of the feminist sass. Loosey was snorting SuperChill like it would never run out.

He grabbed my cheeks with his New England clam chowder hands. 
"This is for all we've got," he spit like a wild man. "For everything we've ever loved." Jethro opened a Webster's Dictionary to the L-words and scanned the onionskin pages for something we could wrap our heads around. Someone had torn out the page with the "love" entry, and we were left to our own devices. Meaning-making in the clutch had never been one our strong suits.

"I’ve forgotten what I started fightin' for," I said.

Niggas fell out laughin’.

"Dude sounds like a whiteboy jheri curl with the runs!"

That got them going all night. One after another put me on blast. Some cat with a megaphone went person to person asking politely for first-rate busts. All Barbara Walters attentive and shit.

"And you, sir," he said to some new jack in an Adidas tracksuit, "do you smell pussy up in here?"

"I sho nuff do, partna!" the man said, convinced. "And the wind is blowing from thata direction!"

He pointed at my waist like a prosecuting attorney. I bent over, pretending that my shoelaces were untied. Dodging the blame something awful. Tiger pounced in the ring to save my black ass.

"All right, all right," he cooed. "That's enough, you cotton-headed fools."

The crowd settled down and set their cell phones to vibrate.

Tiger played the role of MC. "Now that all admissions have been paid in full, it's time to get down to business. Three rounds of unadulterated carnage have been scheduled in today's bout. The winner will be the man left standing after the final bell rings." 
He looked over his shoulder at the Episcopalian steeple and gave it the go-ahead nod. The bell tower attendant winked back with his big hips and formal robe and set his sights on big sound. "The Honorable Judge Tyson is presiding over this fight," Tiger hollered, "and both brawlers are prepared to battle to the death."

My eyes bugged out in a heartbroken type of way.

Iron Mike licked his lips and blushed.

I spun around to Jethro and Loosey, frantic.

"To the death? I didn't know somebody was gonna die tonight!"

They both pulled heaps of paperwork out of their sharp leather briefcases and rifled through it. Clauses had been highlighted in bright yellow. My signature and initials speckled the documents like poppy seeds. The block turned into quicksand. Everyone started grabbing for jungle ropes like wild.

I desperately dreamt up hope for some sort of legal loophole, a chance to postpone the fight to the fifteenth of the next month. When the government checks would rain down again and folks could flaunt around the projects, hood rich, and forget all about me and my fool head.

Tyson had eyes like playing card spades. He wanted to club everyone there to death. My mother and father were watching from box seats on the roof of the Laundromat. Each of 'em held laminated copies of my birth certificate and social security card. In case things got realer than this. Too real. To identify my body unedited after the final bell tolled.

I admired their prudence and tucked a Gideon bible down my shorts to protect my most private parts. Lex wiped his face off with a facsimile of the Magna Carta. Our success or failure was documented. Written in the concrete none of us had known in its infancy. 
A lady with a fresh talk show makeover honked the horn of her baby daddy's mama's car, and that was as good as the first shot at the battle of Gettysburg. Lex dropped his gloves like they were empty and drew for his 9 millimeter. I had my .380 cocked and loaded. Aimed at everything God had ever taken away from me. Right at Lex's white-hot villain heart.

Everyone in the crowd took a breath at the same time, and we might as well have been in zero-gravity outer space. Floating in ether and blunt smoke, dyin' to live.

And before Lex or I could pull our triggers and end it all, a caravan of all-black Hummers stormtrooped onto the block like a lunar landing. Our 'hood pigeons flew erratic and shit all over the interlopers' whips. A crime punishable by death.

The wagon train's tinted windows rolled down doom-style and AK-47 fire sprayed the sky like peppercorns. The pigeons dropped out and died on the streets. Little kids started running around, outlining the birds' corpses in colorful sidewalk chalk. They told everyone in attendance not to tamper with the evidence or else.

Lex and I listened in on the scene with our good ears. Iron Mike was shaking in his black-laced boots. His legendary left hook looked like Mother Goose compared to the firepower, and the Champ knew it. Shame let off a brutal gymrat stink.

But before we could file a grievance with the local branch of the NAACP, the AK rifle barrels had been lowered to our level. Shots rang from the shores of the highway exits. The block lit up gunpowder red.

I heard screaming from the gutters ricochet off stop signs and not take a second look. Bodies dropped to the street petrified and got buried in City dust. Muhfuckas trampled each other tryin' to scatter, stepping on arteries and hand grenades in the panic. Black businesses broke down and cried. They knew their place in the riot scene. 
And the shots didn't stop once the guns came out. No one stopped to look at the chaos in the rain. It was every soul here and there for itself. Grandmothers dropped their high school diplomas and swung at the bullets with their purses and canes. Uncles and Aunties ran for Mean Joe Greene's Diner to order Coca-Cola's and hide under the corner booth tables. I saw little girls set up and tear down sweet tea parties in the time it took to shatter an ice cube tray. The future was military industrial technology, and the future was now, in the streets. It flew away slowly in a Goodyear blimp migrating to the South Side for the winter.

I hit the deck like a merchant marine. My parents were doing a Tae-Bo workout tape on the rooftop, burning off the stress. Sweatin' to the oldies while the block filled up with blood.

When the clapping died down a bit I looked around with my cheeks flush to the pavement. Jethro was out cold with a bullet hole through his temple. Chi spilled out of the wound until he drowned in the energy. Loosey didn't have a chest—a Black and Mild cigar stood in for where his lungs used to be. Tiger had flown the coop and was trying to start up his own independent rap record label in Yonkers. Call it something like One More Road to Cross Records, Inc.

Lex Luther and his crew had hopped the nearest spaceship going anywhere. Most of the neighborhood was belly-up from the rounds. Thousands of slugs lodged in the slum buildings behind us, wilting. All while the investment bankers watched in bulletproof vests and updated their real-time actuarial charts to reflect the rising death rates. Premiums were dropping for millions of Middle Americans with handgun permits. It was a beautiful day to be a small-town newspaper subscriber.

Until the last shell hit the ground, and I knew the Hummers were out of ammo. 
I stood up and wiped the leftover blood from every part of me I could see without cringing. Some gunfire sounds echoed off the project towers and got stuck in people's cheap microwaves. It would take hours to defrost them in time for some semblance of family dinner.

The air smelled like Shake N'Bake, and I helped.

The tinted windows on the Hummers slipped away out of their minds. G-Unit Records was rolling deep and weren't afraid to show it, their trigger fingers limp from the massacre. 50 Cent leaned over in the driver's seat, getting a back massage from Tony Yayo and company.

Nah, it was nondescript young black men taking revenge on their own. All, "You can't take the hood out the homie," and shit.

Strike that, it was 50 with his spinning platinum chain lighting the scene up almost pornographic. I shielded my eyes with my gat and squinted around the barrel to see what I could see.

"Go on and squeeze your lil' handgun till you run out," 50 hollered like a dead president. I did what I was told and let off shots until I forgot my Christian name. All the bullets whizzed high or low, missing their dead-aim mark, maybe piercing a tire or two, but nothing the tanks couldn't walk away from. Lloyd Banks died laughing, and no one tried to resuscitate him. Like his time had come and gone and run off to Las Vegas and fallen in love with a stripper. The one who knew more about gettin' down than the rest of us with our heads superglued together.

Ain't you gon' run for yo' backup?" 50 asked.

I looked up for my folks, but the Laundromat had never been there to begin with. Another victim of Ronald Raygun's redline policies from the good ol' days. Mike Tyson was knocked out worse than Buster Douglass. Any survivors had already converted to Islam and accepted the 5\% doctrine. Since the odds were clearly in their favor. 
I took a razor blade from my front pocket and started carving the crucifix namesake tattoo out from under my forearm. The veins bobbed and weaved the cuts and let the ink flow downstream to my wrist and drip away into an afterlife.

"Nowhere to hide," I said, anemic. I felt a pulse in my brain that was the lyric to a Martha and the Vandellas song from the $60 \mathrm{~s}$.

No, it was proof in the pudding of biofeedback brainwave repositioning software. I was the machine, and the machine was falling apart. The manufacturer's warranty had a screw loose.

All the Hummers were doing the electric slide and blasting Billy Ray Cyrus from their subwoofers. Their drivers' weapons had been made possible with generous support from the John D. and Catherine T. MacArthur Foundation. That and some National Public Radio programs geared towards the more virulent members of the liberal white faction doing their best to keep it real.

No, I saw 50 lean his seat all the way back to reveal Code-X sitting shotgun and absentmindedly picking out his Afro. I reached into my back pocket for a handful of SuperChill to settle the shock and awe. But my pocket was emptier than I knew.

The anxiety took on a new head with its own black brain. One Code-X hadn't accessed in our therapeutic psychoanalysis sessions insured and sponsored by State Farm. I called the black brain Papa's Brand New Bag and let it get down to the machinegun music from earlier that I'd recorded into a small bugging device I Scotch-taped inside the collar of my t-shirt. Its purpose was to serve as an impartial witness to the atrocities of handling your own businesss. The Other brain listened to maybe fifteen seconds of The Massacre and said, "Goddamn, we must really hate ourselves something serious."

"Uh-huh, you said it" I answered meekly. 
I had forgotten about 50 and Code-X in cahoots and was getting into a deeper spiritual conversation with myself than before the month of ritual fasting. Papa's Brand New Bag settled into my empty stomach and called me a coward.

"Whatchu know about that?" I asked, defensive.

"Enough to see the worlds you've been building and visiting to take advantage of frequent flyer miles."

I slid a map of my innervisions into the chest pocket of my shirt. Nothing worthy of table conversation in the atlas I drew with the tip of my tongue. The roof of my mouth was its own Southside Bronx. I tried to run from myself but couldn't move. I hollered at Doc for directions to his practice's downtown offices, but dude was off on a theoretical journey.

"Yo, Doc!" I shouted, trying to get his attention. "Show a brother the way!"

50 snapped back up in his seat and smirked hard. Young Buck was in the back, brushing his teeth with Colgate toothpaste and spitting out the open window.

"My toy soulja don’t feel like talkin' to ya no mo', lil' nigga," 50 said, flexing his muscles around the steering wheel and adjusting the rearview mirror. "He say what I want him to say from now on."

I pinched my cheeks pink to check if the pain was still there. The corners of my mouth pulled away, alert to the game.

50 shifted in his seat, turning toward Doc with fire in his eyes. He maneuvered around and stuck his hand deep in Code-X's back, twisting his arm until he was satisfied with the grip and control. The Doc came to life like Pinnochio ready to tell some fibs and watch things grow. I saw him as the good marionette who knows how to pull all the right strings with pharmaceutical reps. 
“Why, hello again, Christian." 50 Cent tried to keep his ventriloquist lips from moving. He didn't want to give away the whole act. "Please call my secretary as soon as possible and set up an appointment for a prescription refill."

The rest of the G-Unit was rolling at the improvised schtick. 50 couldn't resist a lil' bit more.

"The come-down symptoms from SuperChill can be pretty nasty," he snitched, "and we'd like to avoid a crash landing if at all possible." It was a real bad joke.

When 50 took his hand out, the Doc fell forward and busted his head on the dashboard. His eyeglasses shattered to pieces and fell to the Hummer's floormats. His weight slumped over dead to the world without the puppet master's guidance and direction.

"Looks like there's a new Don in your 'hood's drug monopoly game, nigga," 50 said, dice earrings hanging from him like they owned the City. He and the Unit held up brick after brick of compacted, shrinkwrapped Chill, and I heard the brain in my stomach for what it was-a black spider monkey crying for a fix.

\section{Track 71}

I sat down and took my home into my head. The way I meant for it to be was an homage to old Yo! MTV Raps episodes. But it came out convoluted and covered in brine. My black fingers didn't make sense. I compared them to a set of Legos Mookie had let me play with at a sleepover birthday party when we were seven years old. Awkward fitting and off-color

No, the Legos were mine along with a box of Lucky Charms breakfast cereal just in case. I punched holes through the marshmallow bits and wove my mother a necklace. She took one look at it and swallowed the whole thing down. She looked full and proud. I read her a story out of a picture book. We made up a language with our chins on each other's shoulders. Police 
weren't watching in through the apartment window, taking notes on our body movements and investigating the human nature of our interracial relationship.

The inside of my head was a black tar I had only read about in a textbook edited by Harvard's own Dr. Henry Louis Gates, Jr.

Nah, I recognized the tar from the scene in The Adventures of Huckleberry Finn where Jim is almost drowned in the Mississippi. My head took on the tone of Jim's struggling feet, the back of his throat when he cried out to Jesus. No one came from Heaven to help. The story ended there, with Huck wondering how he'd explain everything to the townspeople who didn't mind one less black throat.

I stretched my legs like I had seen on television. The backs of my legs were tree branches. The only nature in the 'hood. Usually, niggas had to drive their mamas' minivans to Connecticut to see so much greenery. I scraped at the bark with my fingernails, and it chipped away easily. Water started to leak out to the ground. I told a joke to the blood in the streets and was alone.

The buildings were as quiet and guilty as sin. Broken bottles on people's heads like crowns while they were in their small homes spreading Cheese Whiz on saltine crackers. Calling it dinner and a dinner party other folks should drop by on their way to the City dump. Their fine furnishings caviared in rat shit and dust.

Ziggy was the host with the most and came up to me like a Martian. He pushed my spine forward while I stretched. My chin grazed the concrete in a déjà vu moment I had picked out of a hat at a rent party once. The time I kissed Ocho on the neck and called her dirty luck to her face. The night I fell asleep with my eyes open and dreamed all the things I saw.

"I heard Doc has the recipe." 
Zig was his same stoic self. From listening to those philosophy books on tape and taking meticulous notes. I reached for the SuperChill in my pockets and found it there, passing time in the same old ways. I dumped it in handfuls on the pavement.

Ziggy added droplets of iodine to see if the shit was pure, but I wasn't positive what chemical reaction was supposed to occur one way or the other. The Chill took the blue drops into itself like acid rain and started to steam and sizzle. Zig draped a bandana over his dreadlocks and leaned his face close to the fumes rising up. Took the whole mess up his nose and beyond. I watched and fumbled with the religious garments draped over my chest. I had a weight that wasn't accurate It didn't line up with the lay of the road.

Somewhere in the 'hood, cats were listening to N.W.A. records and polishing their toy pistols. I saw them with my eyes open and didn't bother asking any questions. They wouldn't have known the answers anyway or heard the questions in the first place over Eazy E huffing helium and floating away like a weather balloon.

I licked my finger and held it up to check the direction of the wind. It was a dead vacuum if I knew what was good for me. I dragged my other fingers through the SuperChill and thought it was cane sugar. A gangster rabbit in a hat with a bat hopped by us and said, "Yo, nigga, why you fuckin' with the sweet life like it's some kinda sandbox game? The fuck is wrong with you?"

"I just have a toothache," I said, brushing him off like a rotten taste in my mouth. My skin grew a toughness similar to the binding of classic Greek mythology. I knew deep down that I was pushing a snowball up the side of a Rocky Mountain, and I hadn't ever left the City.

Now ain't that some shit? 
Ziggy had passed out and fallen face first into his chemistry set. There was nothing anyone could do to help him once he was lost at sea. Sometimes he'd travel for days without food or water and come home cranky and constipated. I liked him best when his mind was free and his flow was unblocked. He carried a weight I recognized in his abdomen.

The rain came over to ask for a cup of the sugar, and I said I had plenty. I rolled Zig's body off to the side of the road like a cigarette butt and started scooping the SuperChill up with my hands and tossing it into the sky. Trying to get it high enough up to where the rain started. Big handfuls where I reared back like Bob Gibson and threw the heat with everything I had. Hard enough to lift me off my feet a little. Enough to think I was going places.

But the powder fell back to planet Earth like a more innocent sounding George Clinton joint. I had the front man's maggot-infested space suit draped over what was left of my body, grateful for the company. Even if my skin was dried out to the point of diner seat leather. Like no one had eaten here in days or taken their coffee black. Like the hip-heavy waitress hadn't taken in orders with the short pencil perched behind her ear.

I was out of business in my skin.

I watched the drugs fall in the rain and wanted a hit that would take the nation by storm. I opened my mouth and took it in like snowflakes from another Campbell's soup TV commercial. Warmed to the bone, and my heart and soul knew the true meaning of salt.

I didn't know my tongue in an intimate way anymore. I couldn't tell stories of how it came to speak for itself. I asked myself for proof of purchase.

Scratch that, I asked myself for the original copy of my laminated birth certificate. 
Run that back, I asked myself for a Barry Bonds rookie card before his head started pumping iron and swinging for the fences.

I got indignant as a motherfucker and refused to field interview questions.

Nah, I gave in before I could even remember how I had filled out the initial doctorpatient confidentiality agreement. The elevator music had been turned up too loud. I had seen someone in the waiting room who looked like a Middle American politician from the front page of a newspaper. I got distracted by state boundaries.

Things aligned themselves in a way as to not convince me of my own wellbeing. I stopped trusting my gut and asked for it to be surgically removed as a precaution.

\section{Outro}

There was one radio in the middle of the street. That one, tuned in to Hot 91.6, The Realest in 'Da Hood. With the volume dial up to the max and a landmine sensor for an on/off button. There were the sounds of booty shakin' all over the 'hood at unreasonable levels. While good working people tried to sleep or listen to the rain playing taps against the gated windows.

I heard the music and recognized it as the plastic band around my ankle in a maternity ward. The letters on the identification badge were smeared unreadable. The nurses handled it like noble sisters trying to get home to their own families and preheating ovens. Even then, I saw their white shoes as the type that would walk out on a nigga when he was at his lowest. I tried, even then, to stretch my arms toward someone or focus my eyes on the delivery tables stained with blood.

No, I heard the radio music and recognized it as the paper strips around the prescription bottles handed to me in white paper sacks at the pharmacy pick-up counter. The letters on the dosage information smeared unreadable from thumbprints. I couldn't make out the ridges and 
forks in the prints to see if they matched my unique swirl, or if they were counterfeit. A case of stolen identity for the FBI to chew on.

The radio was covered in specks of dissolving SuperChill in the street, the drug seeping into the speaker holes and distorting the sounds something permanent. I listened with headphones I had picked up at the pawnshop my father used to manage.

Nah, I had the headphones put on layaway at K-Mart and paid them off little by little, as much as I could manage. The only honest way to hear anything good. And when they were mine, I crawled over to the radio and licked its tuner face clean of Chill, letting my tongue push its luck. 


\section{CHAPTER III: AIN'T SHIT: FREEWRITING TO FREESTYLING}

\section{Writing At All}

The hardest part of writing is writing something in the first place.

Calling something out of nothing with a language that sticks and moves. Pushing it with pulse and body heat onto a blank page to scald the surface written and alive. Getting physical with the unspoken. Olivia Newton John with the same amount of dripping sweat on paper to speak. Touchy-feely till the writing is visible. The correct combinations of movements to match the voices in our heads step for step. Working out the kinks in the choreography to compose. Listening until we can make our bodies talk onto the same sweaty paper with muscle.

It is easier to not-write. To let the unsaid rest.

Dorothea Brande says as much when she opens her 1934 book Becoming a Writer by noting, "First there is the difficulty of writing at all. The full, abundant flow that must be established if the writer is to be heard from simply will not begin" (28-29).

The hardest part of writing is writing something in the first place.

Starting a flow of words to follow. Making it rain. Opening the floodgates.

Not to be taken lightly, these tasks are creation-work of biblical proportions. Rainbows and olive branches out of nowhere. Writing first thoughts with a rib bone in dust and clay. Getting it all started with the Word made manifest. Birthing a firstborn written something-with an emphasis on the labor.

But the labor of getting writing going, of beginning actual writing work, is often overlooked or underestimated by teachers and pedagogues more interested in the mechanics or rhetorical functions of students' compositions once said texts already exist in the world. Like the pieces fell newborn from the heavens, swaddled and ready for critique. Writing instruction (in 
classrooms, style guides, and textbooks) often takes a "here's how to be a better writer than you already are" tone, with an authority figure in composition offering time-honored tips and techniques, relaying strict rules, god-like, to novice writers seeking to "hone their craft" (i.e., make the writing they have already created, and perhaps will recreate in the future, more perfect, more divine).

Brande's response to such approaches to writing instruction is pragmatic: "Unless the writer can be helped past [the difficulty of writing at all] there is very likely to be no need for technical instruction at all” (29).

All the ancient writing wisdom or new age self-help composition insights won't mean a thing if the writing doesn't exist. If the would-be writer can't start by writing something, there can be no further writing instruction because there is nothing to instruct upon.

The hardest part of writing is writing something in the first place.

And with this in mind, I've turned my critical attention to the idea of writing as an embodied experience. How minds and bodies work together to make written work. How the first drops of Brande's notion of "flow," the physical work of writing and sustaining writing activity, can potentially lead to a psychological "flow state." Where writers start composing with their bodies as a way to kick-start and maintain more prolonged creative states of mind that in turn supply imaginative content for future writing. Where writers start by bringing whatever language they already have to the physical process of getting out whatever it is they could imagine having to say.

In focusing on writing and teaching writing as "flowing," I've found it useful to analyze two language traditions that emphasize in-the-moment creativity: the freewriting practices of Peter Elbow and other "expressivist" teacher-theorists, and the freestyle rap practices of classic 
and contemporary hip-hop culture. Both freewriting and freestyling value improvisation and off the top of the head language delivery, and in doing so promote an approach to writing/speaking that is open to the personal, performative, and unexpected.

I'm interested in how writing gets going, moving. What moves writers to get going on their writing and keep going. Freewriting and freestyling offer opportunities for creative freedom to flow for those who feel they have nothing, or nothing good enough, to say. I'm after the language that can only be produced by writers who feel like they don't belong. Flowing makes this language more accessible by emboldening the writers who possess it. By convincing writers that whatever language they have in them in the moment, any moment, is enough to start writing in the first place. 


\section{Trust Issues Pt. 5}

I don't trust myself to teach writing because I'm an audacious hip-hop hopeful instead. Starry-eyed. I read and write hip-hop shit and hope it goes somewhere. On and on and on and on and on and .... Beyond me. Out of my control.

I put on a hip-hop mask and write diversion rhythms to tired break beats. Experimental lyrics to say, "Made you look," while I sneak off stage.

I write behind a hip-hop mask to hide how poorly read I am. To run scared and scour for more source material. I read to sample and cite as my own. Call it my own writing as a provocative misnomer.

My writing isn't my own.

I don't trust myself to teach unilateral authorship - it's not the way I attack art making. It's not how I battle.

Plus, I was a pacifist art student instead. I refused to engage. I skirted the reading list in an advanced creative writing pedagogy course and spent the entire semester deciphering the wisdom of KRS-One instead. Even that practice half-assed and overdue-fined. I skimmed D.G. Myers's The Elephants Teach: Creative Writing Since 1880 and dedicated more attention to Jeff Chang's Can't Stop Won't Stop: A History of the Hip-Hop Generation. To get some perspective. To know where I came from vicariously.

Same story with the ambiguous alphabetized concepts in Wendy Bishop and David Starkey's Keywords in Creative Writing; I was more into the entries in Yvonne Bynoe's Encyclopedia of Rap and Hip Hop Culture and proved it with retention. Now my recall comes up counterculture trivia and show-off instead of pedagogy, and I'm paying for it in perennial firstday-of-class jitters. Imposter-doubt. Regret of the under-qualified. 
I should've listened more closely to the course lectures on aesthetics and classroom politics. Professional etiquette. Roundtable manners. Generative theory and the cult of the artist crucified. I should've presaged Ezra Pound's Cantos as anti-Semitic and damned them before reading discussion instead of listening to Nas's God's Son. I should've memorized each volume of the Harvard Classics as a jumping off point. So I could cross-reference the hackneyed themes future student work. Instead of fact checking the "50 Greatest Hip-Hop Songs of All Time" compiled in the December 2012 issue of Rolling Stone magazine. I should've pumped myself up with pep talks on how to more confidently perform the role of arbiter of good taste.

But my mouth was too dry from freestyle rapping to myself alone, so I spent the time set aside for the pedagogy course's final exam transcribing William "Upski" Wimsatt's Bomb the Suburbs by hand into an empty test booklet. Word for word until I really started believing in my answer. Until I could imagine my well meaning professor letting the longwinded response slide, taking it in stride as a piece of high-stakes conceptual poetry within a student-centered classroom model.

When semester grades were posted a week later I had an "Incomplete" and a bad attitude. I called the evaluation poetic justice. Player hating. One of the prices you pay to stay true to the game.

I claim hip-hop to decenter difficult discussions about teaching writing. An epistemology of weed smoke and mirrors to sidestep "craft," grade inflation, and the Western canon. So when I'm asked to take a stand on something literary I can say I'm on some other shit entirely and brush the whole thing off my shoulder. 


\section{Negative Pedagogy}

Within a month of my first success at writing there was someone there to tell me I wasn't shit. To call my writing shit and me for making it. To bring me down low and humble me in the eyes of my elders. To not let me get ahead of myself. To make sure, just like, "The streets that nurtured Lauryn Hill," in, "Every Ghetto, Every City," that, "I'd never go too far.” So I'd stay home and write shut-in.

Someone with enough say-so from my neighborhood shouted, "You ain’t shit," as a reminder of where I come from and a warning not to stray. To intimidate me out of moving on. A traditional arrested development tactic designed to keep me always asking permission. To keep me doting and docile with a smile. To handcuff me to a deferential politeness I learned in Sunday school and creative writing workshops. A level of restraint reserved for the pious and learned.

Someone in a position of academic authority said, "You ain't shit," with an air of educated enlightenment, so I took it as the teacher's edition of a textbook with the correct answers printed in bold at the back. I followed the curriculum to the letter and kept to myself. I was the teacher's pet with a perfect record. I sat quietly with my hands behind my back and resolved to speak only when spoken to.

Only no one said anything else.

So all I heard was, "You ain't shit" over and over in my head like a fatalist mantra. Or someone might have said something more, but I couldn't hear it over the initial, "You ain't shit," coming in louder on repeat. Sounding truer. "You ain't shit" seeming the most believable, so I called it orthodoxy and started reciting it like religious gospel. Taking it as self-evident. 
Enough that now when I sit down to write I hear, "You ain't shit" as a starting point. A premise to prove one way or the other. A self-fulfilling prophecy. Now I approach writing believing it's shit and hoping no one else will notice and ask me to explain myself. 


\section{Trust Issues Pt. 1}

I don't trust myself to teach writing because of my own fraught relationship with writing. Specifically, whether or not I ever want to write again. Or, whether it's unethical to encourage others to write when I don't know how long I'll be able to. A “do as I say, not as I do," approach to pedagogy with all the guilt and hypocrisy tastefully kept off the syllabus.

As an example: Open any of my old or current freewrite notebooks to random pages and you'll probably read something about how I never want to write or teach writing again. Page after page of anguish over my struggles with writing. Pages of confusion, distress, exhaustion, self-doubt. Pages of writing this all out instead of just not writing. (And this says something important about the nature of the anguish over not-writing instead. The struggles that come from not-writing, too.) But read any of my notebooks and the struggles are there, over and over, in shaky black and white.

And I wonder what my students would think if they read my notebooks and knew how terrible writing can be for me. Whether or not it would be ethical to let them know. How they might relate to me differently as a teacher, knowing. How they might approach their own writing differently knowing how much their teacher suffers on account of the course content. How their knowing might affect their relationships with their own writing-induced difficulties.

Because up until now students have come to writing classes and told me their struggles with writing. Semester after semester on schedule. And their telling comes with implicit expectations. They tell me their writing struggles secretly hoping I'm not afflicted by the same struggles, secretly hoping that I've overcome the struggles and can pass my conquering wisdom on to them, my students. So they don't have to struggle anymore, and writing can finally be recognized as enjoyable enough to keep at it until one's good enough to teach writing like me, 
their teacher. (Why else would I do it?) Or at least enjoyable enough to pass their writing courses without giving up or dropping out.

My students tell me, in their own ways, that if their relationship to writing were more like what they think my relationship to writing must be, then writing would be easier for them. Because I'm the teacher, so writing must be easier for me. Or I wouldn't be allowed to teach in the first place. Like, if writing were a day-to-day struggle for me, too, I wouldn't have the credentials or authority to teach. Because teaching a practice so often gets equated with subject mastery and, subsequently, performing a level of subject mastery that makes the practice appear easier or effortless to developing students. And my students want that same easiness or effortlessness they think I have because it means they wouldn't have to struggle so much and experience all the distress that comes with struggling.

I don't know how to tell them how much I struggle with writing without losing their confidence in my ability to address their individual writing struggles as well. I don't trust myself to teach writing when I feel like the most I can ever offer my students is myself struggling there with them, but no real relief. 


\section{Trust Issues Pt. 6}

I don't trust myself to teach hip-hop practices either because I bought rap bravado from a big box store in the suburbs. When it conveniently came to my neighborhood pre-packaged with an "On Sale" sticker stuck to the front. So I could flex my purchasing power like a boss. So I could appropriately appropriate and call it “ just business.” The manager on duty and I sharing the same hue and pop cultural heuristic: If you own it, you know it. Until I built a modest private collection and called it a knowledge base. Until I started speaking from my knowledge base and calling it authoritative, an "important new voice in the field."

The whole thing feels a little too much like Norman Mailer in The White Negro. Too vocal. Embarrassingly so. Like hiding the cover when I read Carl Van Vechten's Nigger Heaven in public. Or self-censoring the n-word from the car stereo during a joyride. The whole thing is too close to Danny Hoch's Whiteboyz mixed with Adam Mansbach's Angry Black White Boy and the best intentions. All of it informed by the scholarship of Bakari Kitwana in Why White Kids Love Hip Hop. Broken down into fetish and fandom. Zealotry the new research.

And it would all be cool if I could keep it to myself. Something like Ziggy Marley singing "Personal Revolution" in a pre-hip-hop reggae tradition. So it would come off as discipleship instead of proselytizing. Practicing what you preach instead of charismatic leadership. Day-to-day faithfulness. Private worship always less abrasive than gospel spreading. Less heretical in the spotlight. Less wolf in sheep's clothing.

But I have heard the good news and am not ashamed. I am shameless. And it has translated into performing Poor Righteous Teacher so well I've almost convinced myself. 


\section{Intro to a Freestyle Manifesto}

In hip-hop culture, "To freestyle is to create rhymes on the spot-spontaneously and contemporaneously — as opposed to memorizing and reciting previously written works" (Bynoe 141). But it's more than this because it's not so much about who says what in the moment, but how one opens oneself to the creative moment to say anything at all. To freestyle rap is to respond to the beat(box) as originally, creatively, and (un)consciously as possible within a community (cipher) of likeminded peers — and keep going.

Freestyling is to keep going off the top of one's head with style.

To freestyle is to spit stylized language from the body indefinitely, on and on to the beat until the freestyler forgets her body for the language. Until she is the language itself flowing indefinitely to the beat. Until she flows to the beat in a flow state that supplies and bears witness to the language indefinitely. Freestyling as an embodied flow state of being and creating like something out of a Mihaly Csikszentmihalyi text or TED Talk. Where to enter and maintain the creative psychological flow state is more important to the "success" of the freestyle rap/rapper than the language-content that gets spat out physically during any individual freestyle session.

From a broader perspective, freestyling as a practice is as counterintuitive to the commercial rap industry as, say, freewriting is to higher education as an institution. Both center practitioners' holistic creative processes rather than the created products (flowing itself more important than what is produced while flowing). As a result, both complicate notions of revision, evaluation, and commodification by focusing on ephemeral states of being that are difficult to replicate and quantify. Freestyling and freewriting blur conceptions of authorship and ownership, raising important questions about whom the improvisational practices and subsequent oral/written texts are for and how they can be valued/evaluated. 
In the end, freestyle rap isn't even about rap, it's about rappers reaching the psychological flow state that makes embodied freestyling possible. The raps themselves are manifestations of a way of approaching language- and music-making "spontaneously and contemporaneously," this approach opening creative space for unexpected utterances. Freestyling (and, similarly, freewriting) is loaded with creative potential because it rejects the formulaic and fussed-over in favor of the fresh. It demands a sharp tongue and a short memory. It promotes "being" and "becoming" ahead of "producing." What could be imagined and voiced in the present rather than what's already been thought of and heard in the past. 


\section{If I Didn't Pt. 2}

If I didn't freestyle, you'd never hear a word out of me. You'd think I was tone-deaf or worse. Soulless and damned. A blue-eyed soul brother run over dead by Don Cornelius's Soul Train or Reflection Eternal's Train of Thought. Mouth shrink-wrapped like unopened 8 Mile soundtracks. Mint-condition silence. Top value at a silent auction. Priceless compared to the shit I talk.

I "forget everything else and flow"(Escher 3). I flow to forget. I write everything I've forgotten and call it freestyling. I freestyle until I reach that higher ground outlined in Mihaly Csikszentmihalyi's Flow: The Psychology of Optimal Experience. I freestyle until I feel fluent in the language off-the-top-of-my-head.

"To write fluently is to enter the state of "flow,'” says Rjurik Davidson in the essay, "On Writer's Block" (28). I freestyle till I'm fluent in purposefulness. Enough to keep flowing indefinitely. Davidson encourages, "The purpose of the flow is to keep on flowing," so I keep on freestyling indefinitely for the sake of it (29). Until I've proven fluency beyond a reasonable doubt.

I freestyle to outflank unreasonable volumes of self-doubt and keep going. I freestyle battle with the voices telling me I ain't shit. Until I feel like writer Anne Lamott when she mentions how her "mind spends much of its time having conversations with people who aren't there" (26). Until I feel like the friend who emails scholar Sharon Marshall, "I'm at war with myself when I write" (16).

I freestyle until I feel like Black Thought on "Guerrilla Monsoon Rap," bypassing external threats because I "gotta battle myself" first and foremost. 
I freestyle to vocalize the battle already there in my mind when I write. Words the war cries and white flags for mercy at once.

I freestyle peace treaties doomed to fail. 


\section{Because: Asleep}

I couldn't write anything because I was dozing. The SuperChill had kicked in and taken over. Straight into my bloodstream to metabolize and mediate. Groggy-eyed, the prescription bottle started to look like a pocket watch on a platinum chain. I tried to read the warning labels while my vision shifted back and forth, Notorious B.I.G.'s "Hypnotize" on the radio on the nightstand. Side effects included: fatigue, dry mouth, irritability, constipation, stomach pain, drowsiness, dizziness, suicidal thoughts, lack of willpower. I took the risks with a glass of warm milk and started counting black sheep backwards to see how far I could take it before knocking off.

I slept away my symptoms for as long as it took.

When I woke up, I hadn’t written anything. My laptop was hibernating in an overnight bag. It hadn't seen the break of day or the changing of the seasons. I hadn't sleepwalked with it under my arm to my office desk, woken it up, and typed my subconscious into a piece of lucid writing. My dream journal was empty, and my notebooks were stacked like untouched pillows. I hadn't handwritten anything anywhere while I was under either. There was no account of my time spent sleeping. I had nothing to show for the SuperChill doing its thing.

And I panicked even more awake because I sensed a deadline had passed or was coming to pass. I sensed a due date in space and time and panicked out of my head at the prospect of exchanging overwhelming expectations for original documents. I sensed the sleep had cost me in word count productivity and panicked over what I'd have to do to cover my lapse, make up for it and then some. So no one would notice and embarrass me with shameful reminders of quota responsibilities, timesheet entries, and quality reports. So no one would question my 
commitment to Erykah Badu's notion, on "Master Teacher," of staying woke. Always alert to what needs to be said.

I panicked enough to pick up the prescription bottle again like a pocket watch and clock out. To drop a dose and feel the deadline illusions die away into nothing. To feel the side effects full-blown and welcomed. To let the SuperChill have its way with me and my words.

I fell asleep dreaming to wake up a writer somehow. 


\section{Games}

I don't teach writing. I meet with other writers twice weekly, and we play games instead of working. Writing games instead of labor. So we won't be paralyzed by the thought of work, overwork, or our inabilities to work well enough. So we'll have written something, even if it's a mess of work. We make individual messes with words for months and call the messes written work. Important starting and/or ending points. The beginning of something written. Something better than nothing. We play games about order and naming and writing better than nothing at all.

We pull unofficial rules and regulations from Mel Gooding's A Book of Surrealist Games because the text sounded out of this world. So the writing feels out of our hands. So anything rational or irrational could happen and still be part of the game. The outcomes of the games offering a sense of surprise, with the ability to surprise ourselves and each other a major focus of our twice-weekly meetings. Our work taking on a daydream rhythm we didn't expect to hear or feel. Rhythms in time and structure.

Starting with rules like, "Sit at a table with pen and paper, put yourself in a 'receptive' frame of mind, and start writing. Continue writing without thinking about what is appearing beneath your pen. Write as fast as you can" (Gooding 17). The game like writing faster than you can think, with an emphasis on, "unpremeditated free-association" (Gooding 17). The idea being that we always have something to write, even when its feels like our minds and hands won't work or work together to produce written work. The game building confidence in our messes because we can't lose. The messes not synonymous with forfeit. The rules themselves prohibiting loss. 
And sometimes between playing games we talk about who makes the rules for written work outside our games and twice-weekly meetings. Whether or not we have anything in common with the rule makers or if we'd even want to. How we can rework our messes to have more in common with other work. How we can make our messes work for us beyond playing the games.

Or we play unashamed, like there's nothing outside our daydreams to answer to. Or we play winner takes all, with no opponent in sight. 


\section{Not-Writing}

I know people who post "anti-capitalist love notes" with messages like, "You are worth so much more than your productivity." And these notes don't make any sense to me because I'm a writer. Writers produce writing. If I don't produce writing, I'm not a writer. And if I'm not a writer, I don't know who I am or what I do.

All I know is production as self-identification. All I know is more and more writing, so I can point to the work and say, "See, this is who I am. This is what I do." Proof. Without the writing, there is nothing to point to. There is no proof of me. When I can't produce writing, or can't produce enough writing, or can't produce writing well enough to recognize myself, I don't have a name. There is nothing to be "worth so much more than" in the first place because there is nothing and no one.

Alison Croggon understands this in her short essay “On Writer's Block.” She asks, "If I have structured my life in order to permit me to write, what does it mean when I can't?" (8). Croggon calls all the times she can't write, all the things she does instead of writing, "notwriting," and laments, "Not-writing can be a unique misery, a special condition of existential uselessness" (8). And she's right about the misery and the uselessness because I feel it in my weak fingers when I can't write or point. When I forget my name. When I can't do what I can always do and wonder what else I've lost.

And it makes me want to steal a can of spray paint from a hardware store and tag, "Prove It," over the anti-capitalist love notes that don't make any sense to me. To see what the person who posted them could say without getting all metaphysical. To prove to myself that I can at least write two words I believe in. To be a writer again, for a moment, and remember my name. Before it all fades into more miserable not-writing. 


\section{Rapper Trickster}

I'm not a writing teacher; I'm a rapper with the proper academic credentials and professional attire to fool and front my way into an English department. Check my CV for the subterfuge proof. I'm an MC with a college costume and a university library card. What happens when a Master of Science degree blends with the message behind Erykah Badu's "Master Teacher." Staying woke enough to pass it on to others. And the benefits have been small venue collaborative performances put on by Illinois taxpayers. I make publically funded paper.

I write my own papers like bait and switch requirements to move up through the teaching ranks. Adequate yearly progress and meritocracy politics to prove myself worthy of an audience. I write behind an MF Doom rap mask at home and change into faux-tweed jackets for work, convincing enough to get to the head of the class unnoticed. The name I scratch in white on the chalkboard on the first day of the semester is a see-through alias. A coy cover my parents handed me at birth. I put it on my syllabus as a palindrome prank.

After my last promotion, I started practicing a trickster pedagogy I learned from a course on the African American vernacular tradition. The whole thing more or less outlined by Henry Louis Gates, Jr. and Nellie Y. McKay in The Norton Anthology of African American Literature. I stole my approach to teaching writing word for word from the folktale excerpts in Talk That Talk: An Anthology of African-American Storytelling. Now I'm a cotton-tailed Brer Rabbit scholar, an Anansi spider straight out of Charlotte's Web by E.B. White. I teach writing like a second-rate tar-baby molded out of Elmer's glue.

And it's all to hide that I'm really a rapper instead. An MC with stage fright who hides behind papers and masks and syllabi but still can't kick the jitters. I perform teaching writing to get my language fix, enough to remember my name and pay my rent. But every lesson is an act 
of signification. A call-and-response with final grades attached. I hold class like a microphone and tell my so-called students to say, "Ho!" in their own ways. In print. We carry on back and forth, and I show them how to perform writing that moves the crowd. Makes people believe. All the little tricks I've picked up from performing for so long. 


\section{Used to Teach}

I used to teach writing like I knew what I was doing. Like I had everything under control. Like I was in control. I stood up in front of people called "students" with copies of MerriamWebster's Collegiate Dictionary, Roget's $21^{\text {st }}$ Century Thesaurus, and Strunk and White's The Elements of Style in hand and held court. Like court was in session for the semester. Like I was judge, jury, and executioner, and the textbooks were written law. Everything already on the books. I taught writing like I was above the law.

All of this even after I'd read Paulo Freire's Pedagogy of the Oppressed and knew better. After I'd read bell hooks's Teaching to Trangress and knew better. After I'd completed all the post-graduate work in pedagogy and kind of knew better. None of it doing nearly enough to silence the voices in my head that said, "You know," and, "They don't," alternately. None of the book learning and dialogue making a dent in the knee-jerk desire to dictate. Teaching was a power play, and I got the lead role. I handwrote the scripts that were monologues. I taught writing in soliloquies.

And I knew almost immediately that the approach wasn't working. The classroom felt wrong because it didn't feel like anything. Instead, it sounded like my head when I can't fall asleep at night. It sounded like backtalk between arcane scholarly articles. A throwback to a bygone generation of professional know-it-alls standing in lecture halls and proving how they got there. Providing a detailed bibliography of their power trip, complete with dry anecdotes and harmless self-praise.

The students looked conditioned for despair. Like they'd seen it all before on schedule since kindergarten. I saw them biding their time until matriculation and beyond. I saw them not trusting me clearly. I saw myself in them on schedule since kindergarten. They kept their eyes 
forward and listless like I didn't trust them. They read the bad faith in my PowerPoint slides and took defeated notes. We were all writing in the dark, with the lights out. We couldn't see each other or the point. We spent our time together apart. The semester was an exercise in dutifulness and distrust. I spent the whole time spouting off, "I told you so," to whoever would listen.

No one was listening. 


\section{Choosing Movement}

If I taught writing, I'd be a ride or die expressivist. A warrior-disciple of teacher-scholars Ken Macrorie, Donald Murray, Peter Elbow, and others with their pragmatism. A practitioner of an approach to writing whose aim is "to better understand how writing comes to be in order to help individuals discover themselves and create the identity preserved in their language" (Burnham "Expressive Rhetoric” 156). Writing like my very identity depended on it. Teaching like it didn't mean a thing. A collective push towards becoming against all odds.

Any time I'd spend with students, I'd call them other writers with me. Writers together learning. We'd teach each other and write to learn from it as well. The classroom would be our bodies sitting together. We'd be the assignments and texts. Everything else would have to come through us first. Our community would be the pedagogy. How we'd turn what we take up into more writing and lessons. A cycle of input and output like an expressivism that "assign[s]

highest value to the writer and her imaginative, psychological, social, and spiritual development and how that development influences individual consciousness and social behavior" (Burnham "Expressive Pedagogy” 19).

We'd be about developing more than anything. Moving ourselves to move an audience. Sometimes pretending to ignore audience all together if it moves us. Moving the "words in [our] head $[\mathrm{s}]$ and putting them on a blank piece of paper" no matter what (Elbow qtd. in Boice and Meyers 482). To get somewhere out of nowhere. To write something into being and ourselves into consciousness. We'd write to wake up and stay awake. The writing itself an expression of our wakefulness. 


\section{Shit-Talking}

Composition theorist James Berlin uses his "Rhetoric and Ideology in the Writing Class" to call expressivism a dirty name. For Berlin, “expressionism” can’t be considered a truly revolutionary pedagogy because it's too writer-centered (484). It's not focused enough on the collective (486). It plays into the corporate coopting of higher education by "reinforc[ing] the entrepreneurial virtues capitalism most values: individualism, private initiative, the confidence for risk taking, the right to be contentious with authority" (487). Expressivism nothing more than an innocent introduction to academic neoliberalism.

Sherrie L. Gradin ultimately comes to expressive pedagogy's defense in her Romancing Rhetorics: Social Expressivist Perspectives on the Teaching of Writing. But before doing so, she expands the list of critiques of expressivism to provide perspectives beyond Berlin's: "The charges [are] that ... expressivist rhetorics lack rigor, are arhetorical because they are solely for self-expression and thereby ignore audience and the social contexts for writing, and are radically individualistic, resulting in a desire only for the self-development and naiveté about social and political realities" (Gradin 91).

And after reading all the criticisms I'm left wondering whether or not collectives are made up of individuals. If it's not revolutionary to identify oneself as an individual within corporate higher education models that see student bodies as consumer data pools (Gradin 108109). If arguing with internal and imagined external critics isn't its own brutal rhetoric. If selfactualization and political awakening are as easy as they sound on paper. Whether or not I can claim to know anything if I don't know myself. And how I can trust myself enough to address any of these issues if I'm not convinced I exist. 


\section{Trust Issues Pt. 3}

I don't trust myself to teach writing because I learned the most about writing myself without a teacher present. Something like Peter Elbow's 1973 book Writing Without Teachers, acted out in real time and space. The words became flesh and embodied beyond academic or peer evaluation. No one over my shoulder. The learning a series of periodical self check-ins, disciplined listening, and page after page of actual writing. In the end, coming to know how I think I know how to write.

The practice went like this: I wrote as much as I could by hand every day for a summer and called it ENG 101: Composition as Critical Inquiry: A Reprise. Alone in someone else's house, at someone else's prolific desk, surrounded by other people's prolific writing, as fast as I could without stopping. An exercise in prolificacy.

I wrote as fast as I could, the language coming from what sounded right in my mind at the time. I listened to my mind and transcribed what sounded right in the moment without worrying. The whole thing revolving around rhythm and timing. Staying true to what I heard. Listening very closely and writing what I heard honestly. Writing what seemed honest without deviating — no matter what. Straying from what sounded right taking on the feeling of lying through my teeth.

I wrote when I wanted to. I wrote when I didn't want to. When my teeth were on edge. When I couldn't sleep or was well rested. I wrote my arm and hand to sleep and back awake again at other times. I wrote to stay awake and listen to myself.

I noted the cadences of my mind. Any notable discrepancies. I took note of contradictions and tensions. Patches of internal dialogue. Endless indictments and demands for authenticity. 
Further rigor. I listened and called what I heard source material. I cited myself as fast as I could in the body of the growing text.

I wrote to the dissonant rhythms of my dysfunctional mind-body. I called the rhythms found breakbeats and freestyled over them with writing. I called the writing my "voice" without knowing any better. The beef so many compositionists have with the notion of tongues. I called the writing freestyle rapping knowing full well what critics at The Source would say. The implications for traditional folkways. Cultural practices bent out of shape. Form and content butting heads and coming away bruised and worse for wear.

I wrote the rhythms of a season's worth of moon tides and myself drowning in them. The sounds I heard and the sounds I created in response as proof of life. In the end I was myself still but more prolific. The text proof-positive I knew what it takes to produce a text. Self-evident and irrevocable. The process of production, the listening and honesty, the transcription and subtle self-corrections stepping in for a teacher over a season when school was out. The process of learning as trial and trial—no error. "Error" only making sense within a system of external evaluation that didn't exist or matter all summer. Writing as a continuing practice of selfeducation and self-trust. 


\section{Getting It Out}

I write with other writers I resist calling "students" because it implies I'm not a student with them. It implies they're not teachers with me. I resist the idea that other writers aren't writing enough or well enough without my say so. That they aren't shit without my instruction. That they're destined to write shit without me. Or write nothing without a writing identity without me. Like I don't write shit with them the same way. Like I'm anyone without them.

Freewriting allows us to speak the same "I am somebody," off-the-top-of-the-head language. Where our minds meet our pens and then some in space and time, together. Freewriting opens a space for writing from different experience levels and literacy backgrounds. The space is a come-one-come-all space. Everyone's languages are welcome. Everyone's writing is good enough to be and share freely.

It's like, "Freewriting is part of a larger theory of writing that views students as individuals who are already writers, people who have legitimate ideas and writing lives that ought to be acknowledged and respected by the teacher" (Wheeler and Carrales 22). Where no one needs me to be a writer for themselves.

It's like, "The practice of freewriting helps communicate a crucial assumption: that students walk into our classrooms already possessing the core linguistic resources they need to develop as writers. Their experience with speech can be the foundation of their written literacy" (Bean and Elbow 18). Where students are writers before they even meet me, with or without me. Like I was a writer before I met them. Class time functioning as a space to build on the language we already have. Express the language no one can deny or take away.

Ultimately, it's like, "Freewriting allows students to separate the processes of getting it out and getting it right" (Marshall 19). And the separation is crucial because if we're too worried 
about getting it right we may never get it out. And if we never get it out it may become something else entirely, something overwhelming, without our say so. With each student-writer coming to class with their own "it" to get out, the same as me. Class becoming an inclusive place to express what we have to, to be anyone moving forward with language.

And the place isn't inclusive without me writing with other writers in the classroom. Without me writing, the other writers are being watched by someone not writing. The watching pushing me back into teacher as watching evaluator. Teacher as observing judge. Teacher having participated long enough elsewhere, having put in enough outside-the-classroom work in isolation, to opt out of the come-one-come-all space. If I don't write, it becomes a come-onecome-all-but-me space, and the inclusivity ethos becomes hypocrisy.

So I freewrite with other writers like Bernice W. Kliman proposes in her article, "Writing With and For Students." Only I resist calling my writing academic role-modeling for other student-writers. Where Kliman writes with her students to "show them how to respond to a call to write," I write to show solidarity with others working (4). Student-writers don't need to witness my responses to writing situations in order to respond themselves. They've been responding to writing situations all their lives without me. But I respond with them in the classroom to show that we are not alone in our responses. We freewrite together to act out how we are always writing together, somewhere. 


\section{History, Freewritten}

In "Freewriting's Origin," Mark Reynolds attributes the eponymous generative writing practice's popularization to early expressivists: "Modern use of freewriting appears to date from the 1960s, first in Ken Macrorie's work and later in Peter Elbow’s” (81). Importantly, Reynolds notes Macrorie's indebtedness to Dororthea Brande and the regimen of 15-minute daily freewriting sessions Brande outlines in her 1934 book Becoming a Writer (82). In citing Brande, Reynolds engages in the important work of situating expressivist practices within earlier writing traditions.

According to colleagues Robert Boice and Patricia E. Meyers in their article, "Two Parallel Traditions: Automatic Writing and Free Writing," expressive rhetorical practices like freewriting are connected to the experimental writing techniques explored by André Breton and his fellow surrealists in the early $20^{\text {th }}$ century. To introduce others to automatic writing, Breton instructs:

"Attain the most passive or receptive state of mind possible. Forget your genius, your talents, and those of everyone else .... Write quickly with no preconceived subject, so quickly that you retain nothing and are not tempted to reread. Continue as long as you like (qtd. in Boice and Meyers 480)."

It's easy to hear Breton's influence in Macrorie's description of "Writing Freely Without Focus":

"Write for ten minutes as fast as you can, never stopping to ponder a thought or consider spelling, punctuation, or grammar. Put down whatever comes to your mind. If nothing comes, write, 'Nothing comes to my mind' until you get started. Or look in front of you or out the window and begin describing whatever you see. Let yourself wander to any subject, feeling, or 
idea, but keep writing. When ten minutes is up, you should have filled a large notebook-sized page" (Macrorie Writing to Be Read 8).

And it's even easier to see how Macrorie's ideas on freewriting influenced Elbow in the opening pages of the latter's Writing Without Teachers:

"The idea is simply to write for ten minutes (later on, perhaps fifteen or twenty). Don't stop for anything. Go quickly without rushing. Never stop to look back, to cross something out, to wonder how to spell something, to wonder what word or thought to use, or to think about what you are doing. If you can't think of a word or a spelling, just use a squiggle or else write, 'I can't think of it.' Just put down something. The easiest thing is just to put down whatever is in your mind. If you get stuck it's fine to write 'I can't think of what to say, I can't think of what to say' as many times as you want; or repeat the last word you wrote over and over again; or anything else. The only requirement is that you never stop" (Elbow 3).

You never stop.

Reynolds mentions that freewriting is "one of the most widely used prewriting exercises," and that writers "appreciate its usefulness in generating new and unexpected ideas," and it's likely writers of generation's past felt the same way about automatic writing's generative possibilities (81). But neither Reynolds nor Boice and Meyers investigate the ways in which automatic/freewriting has been used beyond its function as prewriting technique. None of them note how Breton himself, in collaboration with Philippe Soupault, composed an "automatic" novel, The Magnetic Fields, or how many surrealists, like Aimé Césaire, wrote complete poems using automatic writing. Unfortunately, in overlooking automatic/freewriting's potential to be rather than influence creative writing, Reynolds, and Boice and Meyers, reflect the limited 
perspective too many scholars have on how freewritten texts can exist, become, and function in the world.

Much has been written about how freewriting fits into expressive pedagogies of the 1960s and 1970s, and even more has been written about freewriting's growing use and usefulness in writing classrooms through the 1990s and early 2000s. But not nearly enough has been written about what freewriting can still become, what it can look, feel, and sound like to writers in the future. To keep freewriting's creative potential alive, it is important to continue imagining what freewriting is capable of. 


\section{Freestyling in Hindsight}

My students and I freestyle together to make sound on paper. It's all about volume. The volume of pages in black and white. Taking up space with language and style. Flowing on paper with statements to get to a flow state beyond the page.

Some students have found freedom in freestyling. They tell me later about having heard their voice on paper for the first time and writing to listen and flow. They say it helps I never read their freestyles or forced them to spit them out loud, that it freed them up to flow without worrying over and audience. Stage fright its own overpowering state.

Other students have dissed freestyling and sat with their arms crossed to the beat looking bad. Like Run-D.M.C. with their mouths closed and empty fists clenched. These students have reminded me that freestyling ain't free if it's forced. And the slanted power dynamics of our cipher demand an exchange of words for letters whether we like it or not.

At the end of most semesters, I'm left wondering over the degrees of freedom in writing and teaching.

But I still believe in volume. The sound of ink grinding against paper. The day-to-day grind of returning to blank pages and filling them in an effort to forget them and focus on the flow. Flowing separately, together, in an effort to understand individuality within community. Flow requiring effort, labor, the written work standing in for sweat.

And the payoff is priceless - knowing the street value of a voice. 


\section{Experiments}

I don't teach writing. I meet with other writers twice weekly, and we write experiments that could go either way. Good or bad beyond our control. Hypotheses off the tops of our heads. Scientific method steps out of order if it feels right. If we feel like it. We cause and effect for pages on end until there's nothing but results. We're after results out of nothing. Instead of nothing. The results nothing more than new starting points for further experimentation. Results like nothing special, so we keep curious.

Results that look like something out of The Writing Experiment. Results that could be the offspring of cross-fertilization with specimens from We Who Love to Be Astonished:

Experimental Women's Writing and Performance Poetics. Results that demand further scientific attention. Further research and development funding. We write in rubber gloves and lab coats.

We meet twice weekly in a classroom that's a laboratory and experiment for ourselves. On ourselves like mad scientists getting personal. We experiment on each other's persons. We peer-review like top-notch scholarship. Field notes from the test tubes themselves. From behind a protective barrier. We encourage each other to write hazardous material. We talk about writing like it's broken glass in case of an emergency.

The writing always to see what happens. To prove something. We write to provoke. To stimulate response. The whole point is the surprise of the outcome, the tension from catalyst to transformation. All of it best practiced in groups for more moving mechanical parts. Possibilities for mutation and passing it on. More witnesses to the moment of creation and birth of genius. We write in labs with room for more. 


\section{Trust Issues Pt. 2}

I don't trust myself to teach writing because I don't trust myself. Specifically, the malfunctioning parts of my mind that obsess as a means of making (non)sense of the world, the parts that express themselves in compulsive embodiments of underdeveloped ideologies put to music and lyrics. Where writing meets mental illness and me trying to make something of myself.

I plan writing obsessively, overanalyzing every aspect of production and possible audience reception until the discourse collapses in on itself. To the point that I outthink myself into irrational criticisms, ill-tempered editors voicing that everything that could go wrong did go wrong and the audience bounced. No one paying attention or giving a fuck.

I write compulsively, though, like my mind depends on it. I write faster than my mind to try to short-circuit it into cooperating. I write more and more to try to overload its memory. I write to crash and restart to crash again. The process proving a point about word processing, word processors, and computing. Making things click. Saving.

All under the mechanical influence of psychiatric medications manufactured to make people chill. All while writing to afford the pills in the first place. Brooklyn MC Talib Kweli says, "I feed my family with my pen / It's so real what I write," and that's fine if it works for him. But I write surreality to pay the pharmacy bills in full. My pen is a syringe pumped with placebo and promises of the real thing if the writing comes out clean.

And all this impacts my pedagogy, because how could it not? I teach what I know, and I know writing chaos through chaos. I know writing as much as I can, more than that, and trusting that there's something in the mess that can move a crowd. And if there isn't then maybe it's the 
wrong crowd, or maybe they aren't listening to hear. The all-or-nothing thinking of a bad gambler on the ropes, desperate.

I practice a mad pedagogy. Where I'm like tortured hip-hop genius Lauryn Hill on "Interlude 3," all, "What I've realized I've become is one of those mad scientists who does the tests on themselves first, you see, to make sure they work. And that's when you know, OK, look, I've got something that works. You know what I'm saying? I'm not gonna give you something that I haven't tested for myself."

Everywhere I write becomes a laboratory. Every attempt to write is an experiment. And I'm not so interested in the results. They're not up to me most of the time anyway. I write hypotheses and data for someone else to draw conclusions about because I'm too busy working on my next project. Trial and error over and over again until it's pathology.

I want my students to write experiments for themselves to see what works. I want them to trial and error to exhaustion, until the outcomes meet their expectations close enough or better. I want them to plan their writing obsessively and write compulsively because I've known the manic joy of finding myself caught in the complexities of writing and finding myself. I want them to get caught up, too.

But I worry what will happen if their writing experiments end up differently than mine. If everything blows up in their face, to the point that they can no longer recognize themselves. If I'll have broken the Hippocratic oath or worse. If I'll have inadvertently dispelled their trust in the scientific method.

I don't trust myself to teach writing because I don't want my students to be clinical, like me, as a writer, but I want to teach what's worked for me so far. I don't trust myself to assist with experiments without getting in the way or tainting the outcomes. I want to teach my 
students to write like themselves instead, but I wonder why they would need me to be more themselves. 


\section{Wrote Nothing}

So I didn't write anything. I wrote nothing for as long as I could. I wrote nothing for months and years without anyone noticing or bringing it up politely. Instead of writing I lied around my apartment and read Daniil Kharms's Today I Wrote Nothing cover to cover for kicks. The collection serving as its own absurd aesthetic and ars poetica. A blueprint for posthumous literary misrecognition — but not just yet. More a way to hurry up and wait through a story arc. I read Kharms over and over without writing anything of my own to show off to anyone or publish. Nothing with its own weight and flesh. Nothing with its own historical record. No proof of existence. All while I told myself things like, "You have nothing to prove," and went with it.

Instead or writing I lied around my apartment and read Davis Schneiderman's Blank cover to cover. The empty pages really doing it for me. Without writing anything across them of my own. Without a desire to write a single thing to call them more "complete" or "filled." More as an opportunity to explore how fulfilling writing can be when it refuses to exist beyond the theoretical. I took Blank as an opportunity to write across the novel's pages without having to. Keeping the writing in my mind without embodiment. Without a physical presence to show off to anyone or prove. I theorized what could exist on the pages without having to prove anything.

I wrote nothing into my personal and professional life. I bought blank Mead notebooks at bargain prices and threw them away empty. I refused to answer The New York Times's weekend crossword puzzle clues when my parents called me on the telephone stumped. I mailed blank checks to creditors just because. No amounts or signatures. Project deadlines came and went without anything existing towards them. People I kept in correspondence with went without word for as long as I felt like it.

Not-writing became my new writing. 
I wrote nothing everywhere I could think of, and it was wonderful. It was like I didn't even exist or have to perform my existence so much. I didn't have a name to live up to. It was the least anxiety I've ever felt because nothing was done in my name. I didn't have to sign off on anything. There was no such thing as self-assertion, no affirmation or dissent. I didn't have to perform a personal voice or the politics inherent in vocalizing. I didn't have to stress myself or my selfhood. I didn't have to prove my possession of a voice or self at all. Voices and selves became theoretical and performative, things that could happen in front of others but didn't have to. I couldn't say one way or the other.

I relinquished my right to a say-so and watched what happened. Everything that would happen happened without my say-so anyway. So I wrote nothing as a practice of radical acceptance. I read Tara Brach's Radical Acceptance, and wrote nothing in the margins like it was a religious ritual. I accepted a spirituality of passivity and felt the peace that comes with a vow of silence. I felt better than I could say. I refused to write about how good I felt as an expression of strict religious discipline. I refused to produce any written proof of my existence and existed as hearsay. I felt weightless and told myself things like, "You should have done this lifetimes ago." 


\section{Chaos}

First-year writing teacher Daniel J. Weinstein says, "Freewriting can both embolden and frighten" (171). It can be both ends of the anxiety/exhilaration spectrum, where access to off-thetop-of-the-head content has the potential to surprise or shake or both. Weinstein continues, "The sheer surge of spontaneous, unselfconscious writing can excite, awaken, even overwhelm the freewriter through its capacity to stimulate ideas, emotions, and language" (171).

Freewriting demands the fresh.

I come to freewriting for the unexpected new. I freewrite with other writers to share in the communal caught-off-guard. Where streams of consciousness run chaotic. Speeds and crashes of what is and what could be. Where the unseen starts to speak for itself. Language called out of nowhere to be here now and storm.

Freewriting embraces the chaos of us.

Mark Reynolds notes how "free writing is chaotic by nature" ("Make Freewriting More Productive" 81). Boice and Meyers encourage students to "come to terms with the chaos and discomfort that often accompany and inhibit writing" (486). Sharon Marshall says, "One of the things that scares people most about freewriting is that it encourages students to look into their heads, unmask their thoughts and feelings, and entertain, rather than immediately order and distill, the chaos within" (16).

We freewrite together to say out loud what everyone's already thinking anyway. Only to call the chaos out on paper and call it what it is. Freewriting as a way of calling the chaos by its Christian name and not giving a damn. Writing as soul-speaking. Until we can almost touch infinity-speak. Writing as a tactile trust in the language we carry in us. A freewritten faith that "if 
[we] invite them, words will come" (Marshall 12). Because they've always been there, buried in our mess. 


\section{Free}

I turned to freewriting to feel free in my mind with writing. Like if I freed my mind my ass would follow with writing. Like I had been blocked something awful and started freewriting with dead prez's Let's Get Free running in the background to fight. Writing like a militant freestyle hip-hop optimism. Outflanking the block to write something starting to feel radically political for better or worse. A real or imagined stand against nothingness taking on a freeing potentiality feel.

But it was also all about the Benjamins, like it always is. I started freewriting because the price was right. Free was all I could afford. I didn't have anything left to spend. I was spent. It was free or nothing, and nothing felt too familiar. So I started questioning the free in freewriting

Writing scholar George Hillocks says freewriting, "is free in two senses: the topics are not prescribed, and the writing is not normally graded" (qtd. in Fox and Suhor 34). Boice and Meyers add, "The 'free' in free writing does not have to mean writing anything that comes to mind. It can mean that a writer writes before feeling ready, by trusting and following somewhat vague images for a topic, by putting imperfectly formed ideas on paper” (486).

I freewrote because I wasn't ready to write and knew I never would be. What with the block beyond reason putting in more work. I freewrote as an act of self-trust like I trusted it. An all-out belief through the block. Faith in my abilities to failure all over the place, regardless of standards. An open acceptance of imperfection on paper. Everything I had left and wasn't prepared to lose, documented.

But "free" went beyond cost analyses, low stakes, and surprise to something rooted deeper. More painfully familiar. A tradition less hip-hop conscious and more blues/jazz 
continuum. A more desperate wail and moan. Something like Nina Simone saying, "I'll tell you what freedom is to me. No fear. I mean, really, no fear."

I freewrote because I was afraid and didn't want to be anymore.

Afraid of what the words could mean if they came out wrong. If they came out right, but worse. Fear bad enough to see nothingness as a real option. Unreal levels of fear knocking me off balance to fall. Fear like fallen-world sin and blasphemy. Mistakes beyond redemption. Fear unspeakable.

I freewrote to fall into myself with words and seek salvation.

Since, "Freewriting seeks an open space for expression ... so that we might explore without fear and find out what we think" (Bean and Elbow 6). I freewrote to, "begin the process of writing without fear and anxiety that often makes the articulation of an idea impossible" (Wheeler and Carrales 22).

I freewrote to articulate my fears. To make my fears more articulate. To get the words right in my head before spilling them, spitting them out salty and uneducated. To get right with myself before it all goes wrongheaded. To come correct with the knowledge that, "There's no way to freewrite wrong" (Bean and Elbow 20). 


\section{If I Didn't Pt. 1}

If I didn't freewrite, I'd never write anything at all. There'd be no self-evident documentation. No identifying paperwork for a postmortem. I'd die with language unaccounted for. Mismanaged. Ambiguous assets without a last will and testament. No investments in an heir apparent anthology. Lax ledger keeping into oblivion.

Freewriting saved my life and legacy by force.

I have to force myself to start writing from the beginning, or I'll do anything else that's easier to start. Anything else is easier to start, so I force myself to write as an act of force. I freewrite "to force a beginning" (Wheeler and Carrales 23). I freewrite to proof-positive a beginning and move on from there. I can't move on without a beginning.

"In the beginning, there was the forced-out word."

I freewrite to force my own hand. Saturday sinning. To call my own bluff. Double-down on whatever I have coming and then some. Put it all on the line. Between the lines for broke. I freewrite to strong-arm myself into bankruptcy. I bribe myself with lines of writing like bankrolls. Like everything will be worth it if I start. I write like it could be the start of something risky. 


\section{Talking}

I don't write. I talk on paper. I speak up and speak out and talk shit. All the things that would get stuck in my throat otherwise. All the waste-of-time language I worry I won't find uses for. Everything on the verge of forgotten and moved-on-past. I write it all, talking to myself. I talk to myself and type out the transcripts as documentation that I haven't lost my voice. Proof I can still write my mind whole with words.

I ask other writers to use paper to talk to me. We use paper as a middle(wo)man. I have trouble looking people in the eye. We use writing on paper to talk to each other without making eye contact. Hearing without seeing. The transcripts as documentation that we're not, “wordsmiths without words" (Miller). That we're not, "like singers without voices" (Miller 23). We write to talk, to sing on paper as voice-proof with each other as choir witnesses.

Freewriting is open to writers with something to talk-sing and say. It is open to talksinging as long as it comes out honest. "Freewriting taught me to write as I talk, formerly a cardinal sin. It allowed me to talk honestly on paper" (Stover 61). Freewriting is fine with cardinal sinning as long as it sounds good and true to the singer. Freewriting welcomes writers talking their talk as long as it's really theirs.

Talking requires voices. Voices used to express. The "express" of expressivism grounded in voices (Burnham "Expressive Pedagogy" 19). Freewriting is for experimenting with voices. What writers really have to say when we get a chance to speak from our guts. Speaking from and for oneself with our own gut language. It's rightly argued that, "Expressivism's strength is its insistence that all concerns, whether individual, social, or political, must originate in personal experience and be documented in the student's own language" (Burnham "Expressive Pedagogy" 31). 
Freewriting incites writers to write from the only language we have. Even if ours is a mess of a language unworthy of highbrow evaluation. Even if our writing is nothing more than our shit-talking on paper to put it out there. We're not so worried, or so worried about expectations, so long as there's sound. I ask other writers to freewrite with me with a focus on the sounds of our voices existing. An emphasis on the spaces our voices take up. What we can make of the spaces. The politics of space-claiming and responsible speaking. We freewrite to talk about shared spaces where all our voices are free to speak up and out. 


\section{Singing Pt. 1}

I took an advanced course in composition pedagogy, and on the first day of class the professor said that good writers are born, not built. The titles that made up the course reading list reflected the belief that teaching writing means nurturing the latent talent a select few students already have within them, not attempting to improve the writing of all students regardless of their intellectual and artistic backgrounds or makeups. The "Course Description" section of the syllabus said that writing is like singing, and not everyone can sing well enough to call themselves real singers.

None of this made sense to me at the time, of course, because I had heard Reflection Eternal's track “Africa Dream” that starts off, "If you can talk you can sing / If you can walk you can dance / That's an old proverb from Zimbabwe / You know what I mean." And I knew what it meant because it meant inclusivity rather than hierarchy. It meant all are welcome. No one is left out or considered inept. The proverb implied that we can create cultural artifacts by engaging intentionally even in the human practices often considered the most basic or commonplace.

Anyone who has acquired language and the necessary fine motor skills can write and write well enough to call themself a writer.

This is how it has to be or writing pedagogy becomes nothing more than reruns of old Star Search episodes with writing teachers filling in for the late Ed McMahon. And I'm not interested in judging academic talent competitions or scouting college classrooms for student writers who could make it big beyond the confines of campus walls.

Instead, I'm interested in encouraging students to talk as much as they can in print, enough that they might come to know what it is they have to say. Enough that they might begin to recognize their voice as distinct from anyone else's. I'm interested in putting in the work 
necessary to convince students that their writing can sing if they write with purpose and urgency, from the places within them that make the vibrations of their voices unique, impossible to impersonate or counterfeit.

So in the end, I wrote my final paper for the composition pedagogy course and titled it "If You Can Talk You Can Sing: Teaching Students to Write with the Voices They Have" as a last gasp provocation. The paper functioning as a semester-ending swan song with a bullet. Twentyplus pages of talking on talking until I ran out of breath. Until I ran out of things to say on how sincerely I want my students to write until they run out of things to say. On how I can't sing without them singing along too. Every song benefitting from further accompaniment.

And when final course grades were posted a few weeks later, I was too busy talking to myself to check to see whether my work had been heard. The conversations in my head taking on more importance than anything I could ever be taught or told. 


\section{Writing Garbage}

I freewrote like my life depended on it, and afterwards I had a body of freewriting and felt free. The writing had its own body and weight and weight behind it. I freewrote like I was throwing my weight around, and in the temporary end, for the time being future, the weight was lifted and I felt free. Freedom in the form of no one telling me any different. Freedom in the writing existing at all, where before it hadn't and I was tied down to what it could be if it existed.

I freewrote to free myself of what I had to get out.

But then Peter Elbow called my freewriting garbage. He said freewriting, "produces garbage" (Elbow Writing Without Teachers 7). He said of his own freewriting practice, "I know I produce a lot of garbage" (Elbow “Toward a Phenomenology of Freewriting” 204). He produced garbage along with me, and it didn't make me feel any better surrounded by my own stacks of garbage.

Ken Macrorie told me to "discard [my] bad tries and forget them" (Writing to Be Read 25). Only I didn't know what made tries bad or good, so I wanted to discard all of them just in case. Just in case they were garbage. Macrorie reminded me of the existence of wastebaskets. Wastebaskets as a destination for writing that is a waste of time and attention. Wastebaskets as a threat.

And the threat of wastebaskets loomed larger than my freedom. To the point I no longer freewrote for fear of the wasteful outcome. I stopped writing so it wouldn't turn out trash. I trashed all my ideas for future writing preemptively and wrote nothing to throw away. Knowing if I didn't write it, it couldn't get thrown away. Afraid others would find the trash and throw me out with it. Afraid the trash could collapse on my identity until I was trash too. Until I was buried 
beneath the waste I'd made, indistinguishable from it. The weight of the trash heap equal to what I'd cut loose when I was free and freewriting.

And the weight of it all felt similar to the weight of "you ain't shit" from the very beginning. Writing to prove myself not-a-waste. Writing to prove the possibility of producing something beyond "shitty first drafts" (Lamott 22). The potential to not end up thrown away. Writing to prove productive potential indefinitely without waste.

The weight of the pressure to prove felt similar to what I push against when I get down to the work of writing anything at all. The work of holding myself up beneath the constant threat of being thrown away. Producing under the weight of the pressure. The weight like memories where “you ain’t shit” was completely crushing. 


\section{"I'm Garbage"}

A writer I know called herself garbage and was sure of it. Like it was written. Her voice was sure and flat, and I didn't know how to respond, so I agreed with her and included myself in the waste. The way I felt anyway, right along with her. The way we could share what it felt like to fester. A friendship built on a landfill of things we felt and wrote and said.

"We are the waste and flies swarming, too," I said, and we were talking about our anonymous voices attracting unwanted attention and shame. Bulky with the weight of selfconscious bulges against a trash bag.

"We are what was bought and read and left in a box by the side of the road to be taken and hidden underground," she said, and we remembered everything we'd ever written down and meant so much it stung.

We started to believe each other and kept on going. I showed her some of my handwriting, and she scattered it across herself like a mess. We used our voices to prove the mess with sound.

She showed me a dumpster where she sat and wrote for herself. Written across the dumpster's body with what she could find to write with. We sat behind the dumpster and talked shit about each other until it sank in deep. We wrote something hateful on each other's bodies and said things like, "Here is a new garbage language for you to carry and use." So even our silent movements took on a grotesque literacy. We could read and write a self-hatred we'd read and learned somewhere and agreed upon.

She stood up and started climbing into the dumpster to expand her vocabulary. I wanted to read and be read, so I followed her, and we sat in the garbage around us and spoke to it in the language written on our bodies. We sat with the heat coming off the decomposition warming our 
skin to sweat. Smudging the language we moved and sat in. Even more voiceless when the writing slowly blurred unreadable. Silently alive, we called ourselves the same garbage we sat in.

Miserably alive in our ruined words, we called ourselves greedy, wasteful cast-offs getting by on our self-spread literate reputations. I said something parasitic. She tried to prove herself parasitic and productive without doing anything. I followed her lead until it felt right. Until we held our heads high enough to write "Use Value" on the backs of our hands and feel sorry for ourselves with nothing to show for it.

"Let's write ourselves as corpses playing dead," she said. "Let's write ourselves decaying underground for people to find and excavate."

It was a last gasp death instinct for relevance.

But we were alive and written despite ourselves. Trash-bound as perspective. We could climb out of the heap and stay in the heap just the same, speaking to each other like nothing and comparing the writing on our bodies to bad decisions we'd made concerning audience and intention, syntax and word choice. What to keep and what to throw out. 


\section{Write More}

Freewrite more garbage than anyone could ever read if you need to. Freewrite a garbage heap still piling up to prove something important about production and waste. To prove yourself full of it. More than capable of mess-making when you need to. Anything but abandoned acreage inside you, language-wise. Anything but unspeakable underground landfill cast-off material. Write wastelands to the visible horizon instead, to show off possible landscapes. While people are reading their way through the wreckage, write even more to keep pace and surpass them. Write faster than anyone can climb or critique.

Write imperfect structures like a perfectionist. Freewrite an imperfect place where your "writing can unfurl onto the page in all its imperfection" (Wheeler and Carrales 22). Build a lopsided mansion out of discarded language you scavenged from a dumpster. Careless waste and wrong fits. Driftwood and brass tacks. Freewrite as a way to be "careless and wrong" with your language (Bean and Elbow 14). Write past pretense and zoning restrictions. Write a homeliness aware of its own filth and ignorance. Write like you know you don't know shit. Freewrite like you forgot where you live. Write condemned misdirection.

Compose confusion-trash going nowhere. Freewrite as a form of "writing out [your] confusion" and staying dumbstruck at the same time (Bean and Elbow 15). Write to make a mess of knowing anything for sure. Make a written mess as a way of being in the world. 


\section{Inkshedding/Shit}

Make like freewriter-pedagogue Russell A. Hunt and "inkshed" like it was blood. Like it was bloodletting. Like it was junk out of your system. Write cold turkey and see if it works. If you feel any better. If your circulation improves. Treat writing like "the shedding or spilling of ink," composition nothing more than the "consumption or waste of ink in writing" (Hunt 3). Waste as much ink as you can afford. Spill it in cartridges until the spills start to look like you. Until the mess starts to resemble your features. Fingerpaint a self-portrait and call it writing. Write the waste out of your blood into ink. Soil yourself. Write the soil stains in ink.

Write even more human waste. Black bile into death sentences in ink. The miserable mess you can make of yourself. Treat writing like indigestion. "Vomit on paper" (Stover 61). Let the acid burn holes through your writing and call it editing. Treat writing like elimination. Write "shitty first drafts" regularly (Lamott 21). Write shit exclusively. Refuse to write anything other than your own shit. If anyone questions you, call it writing with guts. Reprimand them for their weak stomachs.

Write nauseous without a remedy. Treat writing like morning sickness. Spill placenta on paper and call it reproductive. Procreative composition as alternative birth plan. Push the writing out of your body like a byproduct. What your liver missed. What is undeniably of you. Down to the chemical breakdown. Write your body breaking down into blood and ash and water mixed into a mess of ink. Write until the ink starts to resemble a puddle of afterbirth past its usefulness. Consider how your writing could be a similar waste. 


\section{Spit}

I don't write, I spit. On paper. Saliva-ink. DNA samples out the side of my cheek. The bad taste in my mouth from bad memories. Bad, broken language lodged awkwardly behind my teeth. The bad I feel like I can't speak but have to, to breathe. What's stuck in my throat. What I'm choking on. I try to write like Talib Kweli and Killer Mike on “Tryin to Breathe,” without losing my breath or hyperventilating. Coughing up the same sick style. I try to write my illness cured. What's killing me softly.

I write to freestyle rap out loud instead, and, “To rap is to spit ... A rapper spits syncopated words that tell stories, show off and teach" (Escher vii). I freestyle write to show off the minimal shit I'm working with. I spit writing and smear it across paper as rococo signification. All while MF DOOM's album Expectoration spins in the background. I spit to the beat of it with everything I've got. One-man-band b-boy spewing from an anxious pen. Even though the only rap requirements are "your voice and a desire to spit" (Escher viii). I spit mouthwater desire and call it all I have to say and learn.

I don't know how to teach writing because I spit instead. And how can I teach spitting something out of your mouth better than you already know how to? You know your taste and flavor better than I could ever tell you different. So instead, I practice a belief in the volume of spit and the necessity to expel. I follow Escher's advice of, "When you spit, be sure to tap into your inner creativity and bring something real, personal and full of energy" (ix). The life-ordeath breathing I brought up in the beginning.

But I don't know how to teach writing like high-stakes breathing. Like you can't breathe on your own without my step-by-step instruction. Like your self-preservation instincts aren't to breathe easily for as long as you can and live. So instead, I practice heavy breathing over a beat 
for whoever can hear. I spit opening bars from my body and teach in the silence that expects response-spit from the cipher. 


\section{Hot Shit}

Hip-hop is open to your shit, the junk inside you and the trash language you use to express it, so long as the shit's undeniably yours. So long as you claim it as your own flesh and write your birth name across it in blood. So long as you birthmark it out with undeniable style, so no one can question who it came from. The family resemblance uncanny. Your fingerprints everywhere like a crime scene- - hot.

Hip-hop welcomes your hot shit, but it's gotta be yours and hot. With the "hot" defined as, "high energy generated in any activity" (Smitherman 171), and the "shit" referring to "almost anything" (Smitherman 257). Hip-hop is open to anything you've got, but only if you spit it with so much creative energy as to produce heat. So people feel the heat beneath their skin, down to their bones, and are drawn to it. Hip-hop welcomes your shit, but it has to be "hot shit," an African American English adjective meaning, simply, "Excellent” (Major 243).

Written shit elevated to excellence through style. Your own style with heat.

Write undeniable garbage until you're crowned king/queen of the trash heap and folks have to start calling you, "Your Excellence." Fill notebooks with excellent garbage to prolong your reign. Write hot shit until the writing decomposes and puts off heat and nutrients as exhaust. Nitrates to promote future growth of the kingdom.

Write heat until you feel like Mos Def, all, "My ink so hot it burn through the journal." Until you write enough "hot shit" that you become "the shit," itself, that is, "a person who is the ultimate; most powerful; above all others" (Smitherman 257).

From "ain't shit" to "hot shit" to "the shit" personified on the page with power. 


\section{Hesitate}

I hesitate to even make connections between freewriting and freestyling, composition and rap, what with hip-hop cultural practices having been coopted by damn near everybody who wants to provide whatever they're promoting a countercultural edge (as I write this, Tupac Shakur has been resurrected to sell Sprite to teenagers in a corner store where Rakim works behind the counter.) When, sadly, some writing scholars have cited hip-hop as the creative force behind the corny activities they bring into their classrooms in weak attempts to get "the youth" geeked about their lyric-inflected homework (see, for example, Forell's “Ideas in Practice: Bringin' Hip-Hop to the Basics"). And when, on the flipside, more respected heads than me have already broken important ground on how hip-hop might fit into secondary and higher education writing curricula (see Hill's Beats, Rhymes, and Classroom Life, and Prier's Culturally Relevant Teaching: Hip-Hop Pedagogy in Urban Schools, to name a few.) When maybe enough, even too much, has already been said about hip-hop and writing pedagogy.

But I'm still interested in how hip-hop's inherent components of improvisation and creative collage can influence the ways I write with other writers. How freestyling continues to inform the way I "teach" other writers to consider writing enough and well enough. How the beats I write and teach to can't stop, won't stop.

I'm still interested in "the literate nature of rap," and the notion of "rap as a site of learning" (Weinstein 274). Where rapping is writing and knowing. Coming to know and passing it on.

I'm still interested in a theory of freestyling as "giving voice to our vulnerability" (Park and Rabi 127). A way of writing out our weaknesses and calling it strength. A shared belief that, "There is enormous value in speaking to the vulnerability and openness required to acknowledge 
our discomforts and uncertainties and still believe that we are good enough" (Park and Rabi 128). Where rapping is writing and not-knowing but still writing on. Through the not-knowing and shit. Hot shit, unknown, to the beat. Where, "The beat is a grounding force, orienting us to the space around us, and the felt rhythm of our bodies" (Park and Rabi 128).

I'm still interested in freestyle writing as a manifestation of the rhythms of our bodies and minds in print. How Ken Macrorie sees freewriting as a tool "for student writers to pick up the rhythms of ordinary speech in their writing" ("The Freewriting Relationship"186). How writers should have opportunities to write "in the rhythmic pattern peculiar to [him or herself]" (Ferebee qtd. in "The Freewriting Relationship" 186). Freestyle writing as a recognition of and accompaniment to some internal music we hear and know but too often are convinced to ignore.

I'm still interested in what "editing" and "revision" could look like within one's freestyle writing practice. How to "improve" or "correct" what sounded right in the moment with what sounds right in the new moment. Spitting over dry saliva. Making hot shit even hotter. Bringing even more heat.

I'm still interested in methods of academic evaluation that could be applied to freewriting and freestyling. How to assess someone's spit. What grade to attach to a writer's improvisations and vulnerabilities. Whether or not I could offer feedback in a freestyle format that doesn't reinforce "ain't shit" power dynamics. Whether or not assessment can be anything besides an interruption of the cipher. A silencing of the beats and flows.

More than anything, I'm still interested in what goes on in freestyle MC Supernatural's mind in the split second before he starts spitting lyrics in Freestyle: The Art of Rhyme. How nolanguage becomes language. Something from nothing, to the beat. I'm still interested in the mechanics and mysteries of improvisational production. An approach to writing with courage 
and perseverance, on and on. A pedagogy of "you ain't shit" inverted and eliminated, where all we've got to write is good enough for now until forever. 


\section{REFERENCES}

8 Mile. Directed by Curtis Hanson, performance by Eminem, Universal, 2002.

50 Cent featuring Lloyd Banks and Eminem. “Don't Push Me.” Get Rich or Die Tryin', Shady/Aftermath/Interscope, 2003.

Aaron, Charles. "What the White Boy Means When He Says Yo." And It Don't Stop: The Best American Hip-Hop Journalism of the Last 25 Years, edited by Raquel Cepeda, Faber and Faber, 2004, pp. 211-237.

Als, Hilton. "No Respect: A Critic at Large." And It Don't Stop: The Best American Hip-Hop Journalism of the Last 25 Years, edited by Raquel Cepeda, Faber and Faber, 2004, pp. 201-210.

Asante, M.K., Jr. It's Bigger Than Hip Hop: The Rise of the Post-Hip-Hop Generation. St. Martin's, 2008.

Banes, Sally. "Physical Graffiti: Breaking is Hard to Do." And It Don't Stop: The Best American Hip-Hop Journalism of the Last 25 Years, edited by Raquel Cepeda, Faber and Faber, 2004, pp. 7-11.

Bean, Janet, and Peter Elbow. "Freewriting and Free Speech: A Pragmatic Perspective." Journal of Teaching Writing, vol. 25, no. 1, 2009, pp. 1-24.

Berlin, James. "Rhetoric and Ideology in the Writing Class." College English, vol. 50, no. 5, 1988, pp. 477-494.

Bleaching Black Culture. Directed by Cas Sigers, Moguldom, 2014.

Boice, Robert, and Patricia E. Meyers. "Two Parallel Traditions: Automatic Writing and Free Writing." Written Communication, vol. 3, no. 4, 1986, pp. 471-490.

Bomb It. Directed by Jon Reiss, Docurama, 2008.

Brande, Dorothea. Becoming a Writer. Harcourt, Brace, 1934.

Bruce, La Marr Jurelle. “'The People Inside My Head, Too’: Madness, Black Womanhood, and the Radical Performance of Lauryn Hill.” African American Review, vol. 45, no. 3, 2012, pp. 371-389.

Burnham, Christopher. "Expressive Pedagogy: Practice/Theory, Theory/Practice." A Guide to Composition Pedagogies, edited by Gary Tate et al., Oxford UP, 2001, pp. 19-35.

---. "Expressive Rhetoric: A Source Study." Defining the New Rhetorics, edited by Theresa Enos and Stuart C. Brown, Sage, 1993, pp. 154-170. 
Bynoe, Yvonne. "Freestyle." Encyclopedia of Rap and Hip Hop Culture, edited by Bynoe, Greenwood, 2006, p. 141.

Chang, Jeff. Can't Stop Won't Stop: A History of the Hip-Hop Generation. Picador, 2005.

Coles, William E., Jr. The Plural I—and After. Boynton/Cook, 1988.

Croggon, Alison. “On Writer’s Block.” Overland, vol. 217, 2014, pp. 8-9.

Davidson, Rjurik. “On Writer's Block.” Overland, vol. 216, 2014, pp. 25-32.

Dr. Dre. "Forgot About Dre.” 2001, Aftermath/Interscope, 1999.

Dyer, Richard. "White.” Screen, vol. 29, no. 1, 1988, pp. 44-64.

Elbow, Peter. "Toward a Phenomenology of Freewriting." Nothing Begins With N: New Investigations of Freewriting, edited by Pat Belanoff, Elbow, and Sheryl I Fontaine, Southern Illinois UP, 1991, pp. 189-213.

---. Writing Without Teachers. $2^{\text {nd }}$ ed., Oxford UP, 1973.

Erykah Badu. "Me." New Amerykah Part One (4 ${ }^{\text {th }}$ World War), Universal Motown, 2008.

---. “On \& On.” Baduizm, Kedar/Universal, 1997.

---. "Master Teacher." New Amerykah Part One (4 ${ }^{\text {th }}$ World War), Universal Motown, 2008.

---. “The Healer." New Amerykah Part One (4 ${ }^{\text {th }}$ World War), Universal Motown, 2008.

Escher, and Alex Rappaport. The Rapper's Handbook: A Guide to Freestyling and Writing Rhymes. $2^{\text {nd }}$ ed., Flocabulary, 2009.

Forell, K. Leigh Hamm. "Ideas in Practice: Bringin' Hip-Hop to the Basics." Journal of Developmental Education, vol. 30, no. 2, 2006, pp. 28-33.

Forman, Murray. General Introduction. That's the Joint!: The Hip-Hop Studies Reader. $2^{\text {nd }}$ ed., edited by Forman and Mark Anthony Neal, Routledge, 2012, pp. 1-8.

Fox, Deborah, and Charles Suhor. "Limitations of Free Writing." English Journal, vol. 75, no. 8, 1986, pp. 34-36.

Freestyle: The Art of Rhyme. Directed by Kevin Fitzgerald, Palm, 2004.

Gilligan, Daniel. “The Art of 'Diss Tracks.”' ALFRED, vol. 5, no. 1, 2014, pp. 14-20.

Goldberg, Natalie. Writing Down the Bones: Freeing the Writer Within, Shambhala, 1986. 
Gooding, Mel, editor. A Book of Surrealist Games. Shambhala, 1995.

Gradin, Sherrie L. Romancing Rhetorics: Social Expressivist Perspectives on the Teaching of Writing, Boynton/Cook, 1995.

Grandmaster Flash and the Furious Five. "The Message." The Message, Sugar Hill, 1982.

Hendricks, Leta. "Getting Hip to the Hop: A Rap Bibliography/Discography." Music Reference Services Quarterly, vol. 4, no. 4, 1996, pp. 17-57.

Hess, Mickey. "Metal Faces, Rap Masks: Identity and Resistance in Hip Hop's Persona Artist." Popular Music and Society, vol. 28, no. 3, 2005, pp. 297-311.

Hill, Marc Lamont. Beats, Rhymes, and Classroom Life: Hip-Hop Pedagogy and the Politics of Identity, Teachers College Press, 2009.

Hinton, Laura, and Cynthia Hogue, editors. We Who Love to Be Astonished: Experimental Women's Writing and Performance Poetics, U of Alabama P, 2002.

Hunt, Russell A. "What is 'Inkshedding'?” Annual Inkshed Working Conference, 6-9 May 1999, Mont Gabriel, Quebec, Canada. Conference Presentation.

Hurt, Byron, director. Hip-Hop: Beyond Beats and Rhymes. Media Education Foundation, 2006.

Kendrick Lamar. "i.” To Pimp a Butterfly, Top Dawg/Aftermath/Interscope, 2015.

---. “u.” To Pimp a Butterfly, Top Dawg/Aftermath/Interscope, 2015.

Kharms, Daniil. Today I Wrote Nothing: The Selected Writings of Daniil Kharms. Translated by Matvei Yankelevich, Ardis, 2009.

Kliman, Bernice W. "Writing With and For Students." Annual Conference of the Modern Language Association, 27-30 December 1988, San Francisco, CA. Conference Presentation.

Lamott, Anne. Bird by Bird: Some Instructions on Writing and Life. Pantheon, 1994.

Lauryn Hill. “Interlude 3.” MTV Unplugged No. 2.0, Columbia, 2002.

---. "Every Ghetto, Every City.” The Miseducation of Lauryn Hill, Ruffhouse/Columbia, 1998.

Leland, John. “Armageddon in Effect.” And It Don't Stop: The Best American Hip-Hop Journalism of the Last 25 Years, edited by Raquel Cepeda, Faber and Faber, 2004, pp. 67-80. 
Lil’ Wayne. "I Feel Like Dying.” YouTube, uploaded by Ay Snead, 3 June 2007, https://www.youtube.com/watch?v=vuyEgvCVYd8.

Macrorie, Ken. Telling Writing. $4^{\text {th }}$ ed., Boynton/Cook, 1985.

---. "The Freewriting Relationship." Nothing Begins With N: New Investigations of Freewriting, Southern Illinois UP, 1991, pp. 173-188.

---. Writing to be Read. $2^{\text {nd }}$ ed., Hayden, 1976.

Major, Clarence, editor. Juba to Jive: A Dictionary of African-American Slang. Penguin, 1994.

Mansbach, Adam. "On Lit Hop." Total Chaos: The Art and Aesthetics of Hip-Hop, edited by Jeff Chang, BasicCivitas, 2006, pp. 92-101.

Marshall, Sharon. "A Case for Private Freewriting in the Classroom." Writing-Based Teaching: Essential Practices and Enduring Questions, edited by Teresa Vilardi and Mary Chang, SUNY P, 2009, pp. 7-23.

Miller, John J. "Wordsmiths Without Words: Examining the Nature of Writer's Block." National Review, vol. 68, no. 9, pp. 23-24.

Mims. “This Is Why I'm Hot.” Music Is My Savior, American King Music/Capitol, 2007.

Mos Def. "Hip Hop.” Black On Both Sides, Rawkus/Columbia, 1999.

---. "Mathematics." Black on Both Sides, Rawkus/Columbia, 1999.

Muhammad, Kareem R. "Pearly Whites: Minstrely's Connection to Contemporary Rap Music." Race, Gender \& Class, vol. 19, no. 1-2, 2012, pp. 305-321.

Murray, Donald M. A Writer Teaches Writing. $2^{\text {nd }}$ ed., Houghton Mifflin, 1985.

---. "Writing as Process: How Writing Finds Its Own Meaning." Eight Approaches to Teaching Composition, edited by Timothy R. Donovan and Ben W. McClelland, NCTE, 1980, pp. $3-20$.

Nas featuring Puff Daddy. "Hate Me Now.” I Am ..., Columbia, 1999.

Park, Sean, and Shahar Rabi. "Improvising Vulnerability Through Freestyle Rap Inquiry." ArtsBased and Contemplative Practices in Research and Teaching: Honoring Presence, edited by Susan Walsh, et al., Routledge, 2015, pp. 125-139.

Pedersen, Birgitte Stougaard. "Aesthetic Potentials of Rhythm in Hip Hop Music and Culture: Rhythmic Conventions, Skills, and Everyday Life." Thamyris/Intersecting: Place, Sex \& Race, vol. 26, no. 1, 2013, pp. 55-70. 
Perry, Imani. "My Mic Sound Nice: Art, Community, and Consciousness." That's the Joint!: The Hip-Hop Studies Reader. $2^{\text {nd }}$ ed., edited by Murray Forman and Mark Anthony Neal, Routledge, 2012, pp. 504-517.

Prier, Darius D. Culturally Relevant Teaching: Hip-Hop Pedagogy in Urban Schools. Peter Lang, 2012.

Rausch, Andrew J. I Am Hip-Hop: Conversations on the Music and Culture. Scarecrow, 2011.

Reflection Eternal. “Africa Dream.” Train of Thought, Rawkus, 2000.

Reynolds, Mark. “Freewriting's Origin.” English Journal, vol. 73, no. 3, 1984, pp. 81-82.

---. "Make Free Writing More Productive." College Composition and Communication, vol. 39, no. 1, 1988, pp. 81-82.

Rodriquez, Jason. "Color-Blind Ideology and the Cultural Appropriation of Hip-Hop.” Journal of Contemporary Ethnography, vol. 35, no. 6, pp. 645-668.

Rose, Tricia. Black Noise: Rap Music and Black Culture in Contemporary America. Wesleyan UP, 1994.

Run the Jewels. "All Due Respect.” Run the Jewels 2, Mass Appeal/RED, 2014.

Sapphire. Push. Alfred A. Knopf, 1996.

Schloss, Joe. "The Art of Battling: An Interview with Zulu King Alien Ness." Total Chaos: The Art and Aesthetics of Hip-Hop, edited by Jeff Chang, BasicCivitas, 2006, pp. 27-32.

Schneiderman, Davis. Blank. Jaded Ibis, 2011.

Sexton, Adam. Don't Believe the Hype; Why Isn't Hip-Hop Criticism Better? Rap On Rap: Straight-Up Talk on Hip-Hop Culture, by Sexton, Delta, 1995, pp. 1-13.

Smith, Danyel. "Black Talk and Hot Sex: Why 'Street Lit' Is Literature." Total Chaos: The Art and Aesthetics of Hip-Hop, edited by Jeff Chang, BasicCivitas, 2006, pp. 188-197.

Smith, Hazel. The Writing Experiment: Strategies for Innovative Creative Writing, Allen \& Unwin, 2005.

Smitherman, Geneva. Black Talk: Words and Phrases from the Hood to the Amen Corner. $2^{\text {nd }}$ ed., Houghton Mifflin, 2000.

Snoop Doggy Dogg. "Who Am I? (What's My Name?” Doggystyle, Death Row/Interscope, 1993. 
Stover, Kim. “In Defense of Freewriting.” English Journal, vol. 77, no. 2, 1988, pp. 61-62.

Style Wars. Directed by Tony Silver, Public Art, 1983.

Talib Kweli. "Rush.” Quality, Rawkus, 2002.

Talib Kweli and $9^{\text {th }}$ Wonder featuring K'Valentine. “These Waters." Indie 500, It's a Wonderful Life Music Group, 2015.

Talib Kweli featuring Black Thought, Pharoahe Monch, and Kanye West. "Guerrilla Monsoon Rap.” Quality, Rawkus, 2002.

Talib Kweli featuting Killer Mike. "Tryin to Breathe.” Train of Thought: Lost Lyrics, Rare Releases \& Beautiful B-Sides, Vol. 1, Javotti, 2015.

Tate, Greg. "What Is Hip-Hop?" Rap On Rap: Straight-Up Talk on Hip-Hop Culture, edited by Adam Sexton, Delta, 1995, pp. 17-21.

The Freshest Kids. Directed by Richie Colon, Image, 2002.

The Notorious B.I.G. “Everyday Struggle.” Ready to Die, Bad Boy, 1994.

Thurman, Wallace. Infants of the Spring. Northeastern UP, 1992.

Tupac Shakur. "Changes." Greatest Hits, Amaru/Death Row/Interscope/Jive, 1998.

Upper, Dennis. "The Unsuccessful Self-Treatment of a Case of 'Writer's Block.'” Journal of Applied Behavioral Analysis, vol. 7, no. 3, 1974, pp. 497-497.

Weinstein, Daniel J. "Polyvocal Freewriting: Inviting a Multivalued Orientation through Spontaneous Freewriting." In Our Own Voice: Graduate Students Teach Writing, edited by Tina LaVonne Good and Leanne B. Warshauer, Pearson, 2008, pp. 170-176.

Weinstein, Susan. "A Love for the Thing: The Pleasures of Rap as a Literate Practice." Journal of Adolescent \& Adult Literacy, vol. 50, no. 4, 2006, pp. 270-281.

Wheeler, Anne C., and Rachel Carrales. "Converging Pedagogies: Freewriting isn't for Babies, Or, Expressivism, Student Resistance, and How to Move Beyond It." Wisconsin English Journal, vol. 55, no. 1, 2013, pp. 22-24.

Whodini. "Friends." Escape, Jive, 1984.

Wimsatt, William Upski. Bomb the Suburbs: Graffiti, Freight-Hopping, Race, and the Search for Hip-Hop's Moral Center. Subway and Elevated Press, 1994. 
Woldu, Gail Hilson. “The Kaleidoscope of Writing on Hip-Hop Culture.” Notes, vol. 67, no. 1, 2010, pp. 9-38.

Wu-Tang Clan. “C.R.E.A.M.” Enter the Wu-Tang (36 Chambers), Loud/RCA, 1993. 